\title{
Archeological Investigations at Fort Boggy State Park, Leon County, Texas
}

Timothy K. Perttula

Heritage Research Center, Stephen F. Austin State University

Bo Nelson

Heritage Research Center, Stephen F. Austin State University

Jon C. Lohse

Follow this and additional works at: https://scholarworks.sfasu.edu/ita

Part of the American Material Culture Commons, Archaeological Anthropology Commons, Environmental Studies Commons, Other American Studies Commons, Other Arts and Humanities Commons, Other History of Art, Architecture, and Archaeology Commons, and the United States History Commons

Tell us how this article helped you.

This Article is brought to you for free and open access by the Center for Regional Heritage Research at SFA ScholarWorks. It has been accepted for inclusion in Index of Texas Archaeology: Open Access Gray Literature from the Lone Star State by an authorized editor of SFA ScholarWorks. For more information, please contact cdsscholarworks@sfasu.edu. 


\section{Archeological Investigations at Fort Boggy State Park, Leon County, Texas}

Creative Commons License

(c) (i) (8)

This work is licensed under a Creative Commons Attribution-NonCommercial 4.0 International License 


\section{Archeological Investigations at Fort Boggy State Park, Leon County, Texas}

by Timothy K. Perttula, Bo Nelson, and Jon C. Lohse

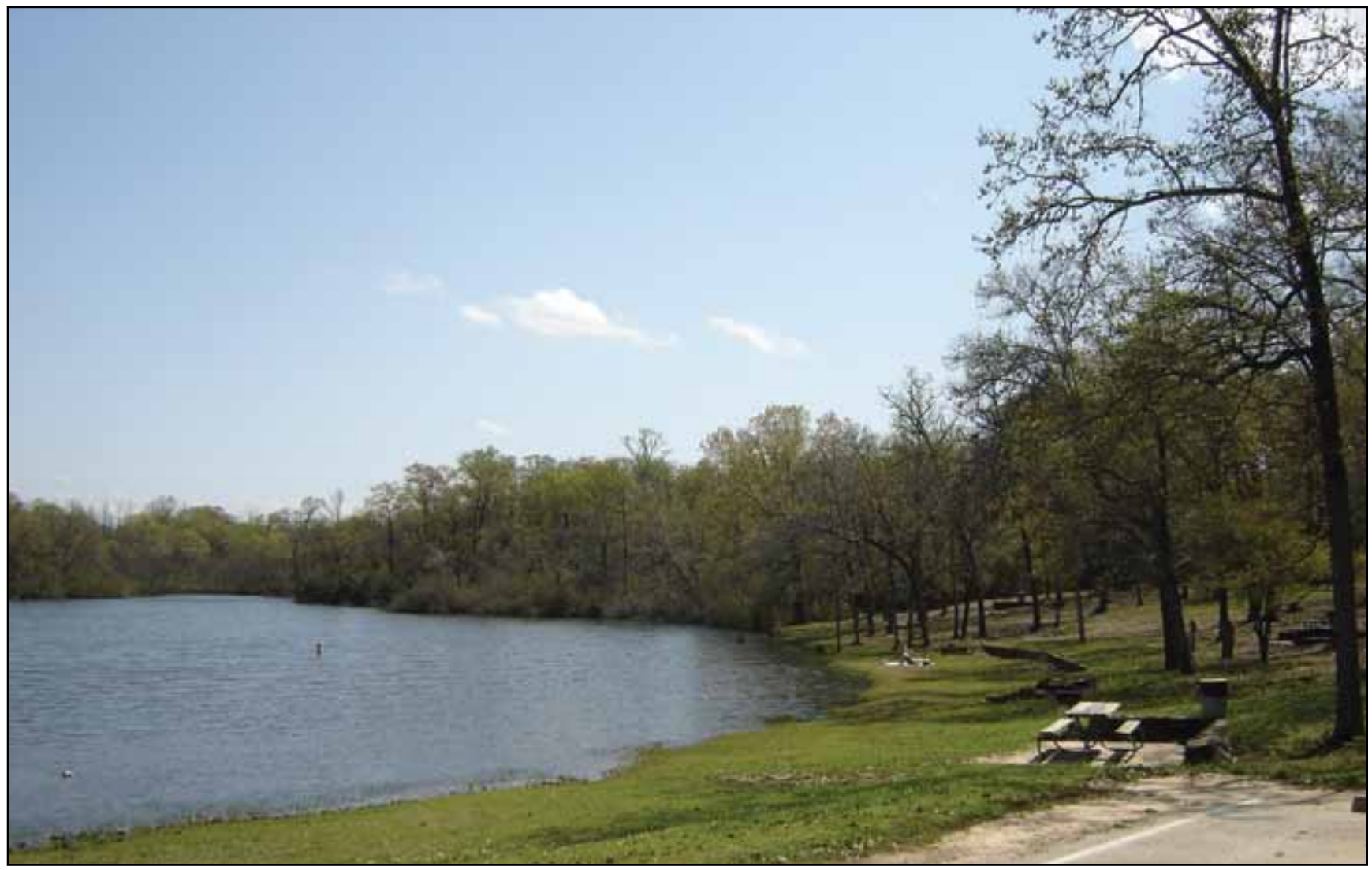

Archaeological Studies Report No. 25 



\section{Archaeological Investigations at Fort Boggy State Park, Leon County, Texas}


Report issued in compliance with

Texas Antiquities Permit No. 5529

Michael Strutt, Principal Investigator 


\section{Archaeological Investigations at Fort Boggy State Park, Leon County, Texas}

Timothy K. Perttula, Bo Nelson, and Jon C. Lohse with contributions by Leslie L. Bush and Cinda L. Timperley

Archaeological Studies Report No. 25 prepared for

Texas Parks and Wildlife Department by Center for Archaeological Studies Texas State University-San Marcos 2011 
The following information is provided in accordance with the General Rules of Practice and Procedures, Title 13, Chapter 26, Texas Administrative Code

1. Type of investigation: survey and site assessment

2. Project Name: Archeological Investigations at Fort Boggy State Park, Leon County, Texas

3. County: Leon

4. Principal Investigator: Michael Strutt

5. Name and location of sponsoring agency: Texas Parks and Wildlife Department, 4200 Smith School Road, Austin, TX 78744

6. Published by the Center for Archaeological Studies, Texas State University-San Marcos, 601 University Drive, San Marcos, Texas 78666-4616 (2011)

Copyright (C) 2011 by Texas Parks and Wildlife Department and the Center for Archaeological Studies, Texas State University-San Marcos

All rights reserved

No part of this book may be reproduced or utilized in any form or by any means, electronic or mechanical, including photocopying, recording, or by any information storage and retrieval system without permission in writing.

For further information about this and other publications by the Center for Archaeological Studies, please contact

Center for Archaeological Studies

Texas State University-San Marcos

601 University Drive

San Marcos, Texas 78666-4616

www.txstate.edu/anthropoloy/cas

Texas State University-San Marcos is a member of the Texas State University System

cover photograph by Wesley Hamilton

copyediting and layout by Margie Elliott

Printed in the United States of America 


\section{Contents}

List of Figures $\quad$ vii

List of Tables

Acknowledgments $\quad$ xiii

Abstract $\quad$ xv

1 Introduction 1

2 Natural Setting and Archaeological Background 3

3 Survey Methods $\quad 9$

$\begin{array}{ll}\text { Site Recording } & 10\end{array}$

$\begin{array}{ll}\text { Site Mapping } & 10\end{array}$

4 Site Descriptions $\quad 13$

Historical Sites that Received Shovel Testing $\quad 24$

$\begin{array}{ll}\text { Historical Sites that were Documented by Photography and Field Observations } & 73\end{array}$

Prehistoric Sites

Multi-component (Prehistoric and Historical) Sites 133

5 Summary 149

The Known Prehistoric and Historical Archaeological Record 149

$\begin{array}{ll}\text { Untested Historical Sites } & 156\end{array}$

6 Management Recommendations $\quad 161$

$\begin{array}{ll}\text { National Register of Historic Places Eligibility } & 161\end{array}$

State Archeological Landmark Eligibility 163

$\begin{array}{ll}\text { Additional Research Needs } & 165\end{array}$

Archival Research $\quad 165$

Additional Archaeological Survey with Shovel Testing 166

$\begin{array}{ll}\text { Backhoe Investigations } & 166\end{array}$

References Cited 171

$\begin{array}{ll}\text { Appendix 1: Shovel Test Descriptions. } & 179\end{array}$

Appendix 2: Soil Descriptions, 50 x $50 \mathrm{~cm}$ Units $\quad 210$

Appendix 3: Artifact Inventory, Fort Boggy State Park Archaeological Site. 213 
Appendix 4: Detailed Analysis of Prehistoric Ceramic Sherds from Fort Boggy State Park Sites.

Appendix 5: Faunal Data from Fort Boggy State Park Sitex

Appendix 6: Floral Remains from 1/4-inch Screen Samples at Three Sites in Fort Boggy State Park: 41LN308, $41 \mathrm{LN} 325$, and $41 \mathrm{LN} 343$ 


\section{Figures}

$1 \quad$ Fort Boggy State Park boundaries showing locations of previously recorded site centroids.

Leona 7.5-minute USGS topographic quad sheet.

2 Map showing the location of Fort Boggy in the Post Oak Savannah of East Central Texas.

3 Distribution of soils within Fort Boggy State Park, Leon County, Texas.

4 Sites that were shovel tested at Fort Boggy State Park. 15

$5 \quad$ Graph showing frequency (0-10, 11-20, 21-30, 31-40, 41-52) of shovel tests for Fort Boggy 16 State Park sites that were shovel tested in 2010.

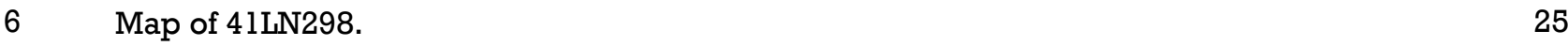

$7 \quad$ Map of 41LN299.

8 Clear glass bottles from 4lLN299: a, Clear bottle made by the Hazel-Atlas Glass Company; 28

b, Clear bottle made by the Owens Bottle Co.

9 Map of the Slimy Oak site (41LN300). 29

$10 \quad$ Map of 4lLN301. 31

11 Map of 4lLN302. 33

12 Map of the Well site (4lLN303). 35

13 Map of 4lLN304. 36

$14 \quad$ Map of 4 lLN305. 38

$\begin{array}{ll}15 & \text { Map of 4lLN306. } \\ \end{array}$

16 Brown snuff glass sherd. $\quad 41$

17 Red hand-painted whiteware body sherd from 4lLN306. 41

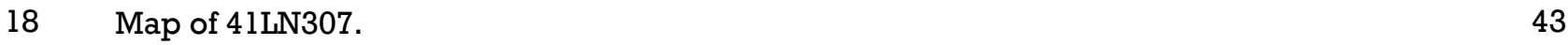

19 Map of the Cedar House site (4lLN309).

20 Green transfer-printed sherd from the Cedar House site (4lLN309). 47

21 Map of the Brick site. $\quad 49$

$\begin{array}{lll}22 & \text { Map of 4lLN313. } & 50\end{array}$

23 Map of 4 lLN314. 52

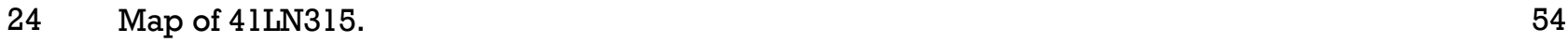

25 Map of the Black Walnut House site. $\quad 55$

26 Map of 4lLN319.

$27 \quad$ Map of 4lLN324. 59 
28 Historic artifacts from 41LN324: top, stoneware pipe; bottom, embossed whiteware rim sherd.

$29 \quad$ Map of $41 \mathrm{LN} 337$.

$30 \quad$ Map of $41 \mathrm{LN} 353$.

$31 \quad$ Map of $41 \mathrm{LN} 355$.

40 Decorated ceramic sherds from 4lLN308: a, engraved; b, closely-spaced parallel incised lines.

41 Map of the Dogwood Beaver site.

Arrow points from the Black Finger Tip site (41LN325): a, possible Perdiz; b, tip and blade fragment.

47 Plain and decorated sherds from the Black Finger Tip site (4lLN325): a, plain rim; b, horizontal incised rim; c, parallel incised body sherd.

$\begin{array}{lll}52 & \text { Map of 4lLN338. } & 107\end{array}$

$53 \quad$ Map of the Fallen Tree site. 108

$\begin{array}{lll}54 & \text { Map of the Karma Ridge site. } & 109\end{array}$ 
55 Map of the Last Chance Quarry site, 4 lLN341.

56 Bifacial tool fragment from the Last Chance Quarry site, found on the surface.

57 Plain and decorated sherds: a, plain sandy paste rim; b, brushed body sherd. 114

$58 \quad$ Map of $41 \mathrm{LN} 342$.

$59 \quad$ Map of the Fern Slope site.

60 Map of the Highway Hill site.

118

$61 \quad$ Map of $41 \mathrm{LN} 346$.

120

62 Map of $41 \mathrm{LN} 347$.

121

63 Map of $41 \mathrm{LN} 348$.

123

$64 \quad$ Map of $41 \mathrm{LN} 349$.

124

65 Late Archaic dart point from 41LN349.

126

$66 \quad$ Map of $41 \mathrm{LN} 350$.

126

$67 \quad$ Map of $41 \mathrm{LN} 351$.

128

$68 \quad$ Map of $41 \mathrm{LN} 357$.

129

$69 \quad$ Map of $41 \mathrm{LN} 363$.

131

$70 \quad$ Map of $41 \mathrm{LN} 364$.

132

71 Map of $41 \mathrm{LN} 310$.

134

72 Friley arrow point from 4lLN310, ST 185, 40-60 cm bs.

135

73 Map of the Halfway House site.

136

$74 \quad$ Map of $41 \mathrm{LN} 321$.

139

75 Expanding stem dart point fragment from $41 \mathrm{LN} 321$.

141

76 Map of $41 \mathrm{LN} 322$.

142

77 Blue shell-edged whiteware rim sherd from 4lLN322.

78 Blade gunflint and salt-glazed stoneware body sherd from 4lLN322: top, blade gunflint

(Unit 322, 0-10 cm bs); bottom, salt-glazed stoneware sherd (Unit 322, 0-10 cm bs).

79 Gunflint from ST 431 at $41 \mathrm{LN} 322$.

$80 \quad$ Map of the Bull nettle site.

81 Map of $41 \mathrm{LN} 345$.

82 Olive green hand-blown bottle glass lip sherd from 41LN345, Unit 345, 30-40 cm bs.

83 Bristol-glazed stoneware with blue cobalt squiggle decorations, Unit 345, 0-10 cm bs. 
84 Map showing the distribution of all sites with prehistoric components at Fort Boggy State Park.

85 Map showing the distribution of sites with Woodland and/or Late Prehistoric components at Fort Boggy State Park.

86 Map showing the distribution of all sites with historic components at Fort Boggy State Park. 159

87 Map showing the distribution of sites with pre-1870 historic components at Fort Boggy 160 State Park.

88 Areas recommended for additional archaeological survey investigations at Fort Boggy State Park. 


\section{Tables}

1 List of previously recorded sites that will or will not be shovel tested at Fort Boggy

State Park.

2 Shovel Testing on Fort Boggy State Park Sites.

3 Sites with artifacts recovered in shovel testing and $50 \times 50 \mathrm{~cm}$ units at depths greater than $80 \mathrm{~cm}$ below surface.

4 Results of the $50 \times 50 \mathrm{~cm}$ unit excavations at the Fort Boggy sites.

5 Prehistoric Artifacts from the Fort Boggy State Park Sites.

6 Historic Artifacts from the Fort Boggy State Park Sites.

7 Distribution of historic artifacts at the Cedar House site (41LN309).

8 Distribution of historic artifacts at $41 \mathrm{LN} 324$.

9 Distribution of prehistoric artifacts at $41 \mathrm{LN} 308$.

10 Aboriginal ceramic sherds from 4lLN308.

11 Distribution of prehistoric artifacts at the Black Finger Tip site.

12 Plain and decorated sherds from the Black Finger Tip site.

13 Distribution of prehistoric artifacts from the Last Chance Quarry site.

14 Plain and decorated ceramic sherds from the Last Chance Quarry site

15 Distribution of prehistoric artifacts at $41 \mathrm{LN} 321$.

16 Estimated Age of Sites at Fort Boggy State Park, based on Corbin et al. (1994) and the 2010 survey investigations.

17 Site Summaries, Fort Boggy State Park.

18 State Archeological Landmark (SAL) recommendations for Fort Boggy State Park sites.

A6.1 Carbonized Plant Remains from $41 \mathrm{LN} 308$ at Fort Boggy State Park.

A6.2 Carbonized Plant Remains from the Black Finger Tip site (4lLN325) at Fort Boggy State Park.

A6.3 Carbonized Plant Remains from the Fern Slope site (4lLN343) at Fort Boggy State Park.

A6.4 Proximate Analysis of Three Edible Tree Nuts and Corn Meal per 100g Dry Weight (USDA, ARS 2010). 



\section{Acknowledgments}

We appreciate the opportunity provided by the Cultural Resources Program at Texas Parks and Wildlife Department, particularly Michael Strutt, Todd McMakin, and Aina Dodge, to complete the archaeological survey investigations at Fort Boggy State Park. We are also appreciative of the efforts of the field crew, under very trying survey conditions, in completing the work. They include Josh Hamilton, Zac Selden, Lance Trask, and Chris Kugler. Josh also completed the site maps for the technical report. Veronica Suarez in the Center for Archaeological Studies at Texas State University produced the artifact figures for the technical report. 



\section{Abstract}

This report concerns archaeological site assessment work at Fort Boggy State Park, in Leon County, Texas, carried out by the Center for Archaeological Studies at Texas State University-San Marcos (CAS) under the Texas Parks and Wildlife Department's (TPWD) annual Antiquities Permit No. 5529. The archaeological site relocation and assessment work took place between July 6 and August 3, 2010. TPWD asked CAS to relocate, assess, and update the character of each of the 80 previously recorded sites at Fort Boggy State Park. Additionally, each site was to be assessed for its eligibility for inclusion in the National Register of Historic Places (NRHP), and for its merit for State Archeological Landmark (SAL) designation.

Based primarily on survey and shovel test investigations conducted by Corbin et al. (1994) and the present CAS work, the Fort Boggy State Park area was used periodically throughout prehistoric times, beginning about 10,000 years ago, with a few periods of more intensive settlement in the Woodland and Late Prehistoric eras. The area was then settled around the mid-nineteenth century by Americans from other parts of the country, and then used more continuously for farming after ca. 1870.

Evaluations of the character, content, and preservation of each of the Fort Boggy State Park sites presented in this report indicate that no sites are considered eligible for inclusion in the NRHP at this time. There are 33 sites with prehistoric and/or historical components that are of undetermined NRHP eligibility, pending test excavations to determine if they meet any of the criteria specified in 36 CFR Part 60.4 for the NRHP, as well as more extensive archival and historical research on the sites with primary historical archaeological components, and archival and historical research on the importance of the road cuts and networks of roads within the boundaries of the state park. These include 10 sites with prehistoric archaeological components, and another 25 sites with historical archaeological components; two sites have both prehistoric and historical components that may have research significance. 



\section{Chapter 1}

\section{Introduction}

This reports concerns archaeological site assessment work at Fort Boggy State Park (Park), in Leon County, Texas (Figure 1) carried out by the Center for Archaeological Studies at Texas State University-San Marcos (CAS). This work has been conducted under the Texas Parks and Wildlife Department (TPWD) annual Antiquities Permit No. 5529 from the Texas Historical Commission (THC), Michael Strutt has served as the Principal Investigator, and Bo Nelson (of Archeological \& Environmental Consultants, LLC) has been the Project Archaeologist. The archaeological site relocation and assessment work took place between July 6 and August 3, 2010.

Previous archaeological surveys at the Park (Corbin et al. 1994) for TPWD recorded a total of 80 sites (4lLN298-375 and 4lLN380-381), including 49 historical sites, 25 prehistoric sites, and six sites with historical and prehistoric archaeological components. ${ }^{1}$ Not all sites were precisely plotted on current 7.5-minute USGS topographic sheets, and many have apparently undergone changes in condition since they were initially described (Todd McMakin, July 2010 personal communication). Finally, because many of these sites were mapped on the basis of general landform features rather than on exact distributions of artifacts from highly controlled surface or shovel test contexts or well-defined boundaries based on UTM points, the boundaries of many of these sites were not precisely known as a result of the Corbin et al. (1994) survey. Consequently, TPWD asked CAS to return to the Park and to relocate, assess, and update the character of each of the 80 previously recorded sites. Additionally, each site was to be assessed for its eligibility for inclusion in the National Register of Historic Places (NRHP), and for its merit for State Archeological Landmark (SAL) designation. The final product of this work is an accurate inventory of cultural resources within the Park, with plotted boundaries, updated site conditions, and information about the perceived significance of each that can be used as a tool for future development of Park infrastructure. 


\section{FIGURE 1. REDACTED}

Figure 1. Fort Boggy State Park boundaries showing locations of previously recorded site centroids. Leona 7.5-minute USGS topographic quad sheet. 


\section{Chapter 2}

\section{Natural Setting and Archaeological Background}

Fort Boggy State Park (Park) is located in Leon County, Texas, and covers 1847 acres (see Figure 1). Approximately 6 miles $(10 \mathrm{~km})$ south of the town of Centerville, the park is located in the rolling Post Oak Savannah of East Central Texas (Diggs et al. 2006:Figure 2). Boggy Creek, an eastward-flowing tributary stream of the Trinity River, flows through the Park, and originates in the west central part of Leon County. The confluence of Boggy Creek and the Trinity River is ca. 12 miles (20 km) east of the Park (Figure 2).

The Post Oak Savannah is a narrow southwest-northeast trending woodland that marks an ecotone between the more xeric Blackland Prairie to the west and south (Diggs et al. 2006:Figure 2) and the more mesic Pineywoods to the east. The woodlands in the Post Oak Savannah consist of broadleaf deciduous forests, primarily including several species of oak as well as hickory and pecan. Small areas of tall grass prairie were present in this physiographic province, including a narrow strip of tall-grass prairie (the San Antonio Prairie, see Diggs et al. 2006:Figure 5) that ran from the Colorado River on the west to near the Trinity River on the east. In Leon County, this prairie lies just south of Boggy Creek and within 2-3 km of Fort Boggy State Park (see Neitsch et al. 1989). Bottomland communities along the Trinity River and major tributaries such as Boggy Creek had a diverse hardwood and/or swamp forest, including cypress, sweet gum, and other flood-tolerant hardwood species on natural levees and alluvial terraces, point bar deposits, old stream channels and oxbow lakes.

Soils in the park are dominated by Wolfpen-Pickton-Cuthbert soils and Padina-Silstid-Hearne soils (Figure 3). Both complexes are described as deep, sandy, and loamy soils that are well drained and/or moderately well drained, on sloping upland landforms, and that occur in settings with oak savannah habitats (Neitsch et al. 1989). Because of the deep sandy soils, it is likely that some sites in the Park occur in buried contexts on side-slope settings and in drainages where colluvial and/or alluvial deposits have accumulated, while others occur at or near the surface in eroded upland settings. Along the Boggy Creek floodplain, soils belong to the Hatliff-Nahatache complex. These are deep loamy alluvial soils (Neitsch et al. 1989).

Geologically, the Park is underlain by Eocene-aged Formations in the uplands and Quaternary alluvial deposits in the bottomlands. The Eocene formations include the Sparta Sand, Stone City, and Weches formations (Bureau of Economic Geology 1968); the Stone City formation occurs in the southern part of the Park, south of Boggy Creek (Corbin et al. 1994:Figure 4), while the Sparta Sand is the predominant bedrock formation. This formation is composed of $200+$ feet $(60 \mathrm{~m}+)$ of quartz sand. In the Park, Boggy Creek has Quaternary alluvium as well as a large Quaternary fluviatile terrace on the north side of Boggy Creek (Corbin et al. 1994:Figure 4). This broad terrace stands ca. $50 \mathrm{ft}$. (15 m) above the Boggy Creek floodplain (Corbin et al. 1994:Figure 6).

Droughts are not uncommon in modern times in this part of Texas. Proxy paleoenvironmental records (i.e., tree rings, isotopes, pollen) indicate that there have been numerous wet and dry climatic spells during the last 1000 years as well as alternating periods of colder and warmer temperatures. More extended droughty climatic conditions may have characterized much of the apparently warmer and drier periods between ca. 8100 and 2400 years B.P. (Gadus et al. 2002:Figure 4) during the Middle and Late Holocene periods (Bousman 1998). Modern climatic conditions, with a number of moist or dry cycles, began about 
2500 years ago, with an increase in arboreal vegetation during the Late Holocene.

With few exceptions in the last 1000 years of the prehistoric era (Bruseth and Martin 1987; McGregor and Bruseth 1987; Gadus et al. 2002), this part of the state of Texas was first settled by mobile huntergatherers and foragers, and remained an area lived in by residentially mobile hunter-gatherer populations until the time of European contact (Story 1990; Fields 2004; Foster 2008). Previous archaeological investigations have shown that the greater East Central Texas region shares cultural affinities with Central Texas, East Texas, and North-Central Texas (Bruseth and Moir 1987); diagnostic artifact types from each of these three regions can be found here. In terms of prehistoric occupation, the Post Oak Savannah region is best known for its Late Archaic and post-Archaic Woodland adaptations as well as its Late Prehistoric sites (Fields 1995, 2004). Some finds dating to the Paleoindian (ca. 1 1,500-8,000 B.C.) and Early (ca. 8,000-5,000 B.C.) or Middle (ca. 5,000-2,000 B.C.) Archaic periods are present, although these tend to be scarce by comparison to the Late Archaic through Late Prehistoric period archaeological remains. Archaeologists' ability to clearly discern differences between Archaic components is often hindered by a number of factors. These include the sandy nature of regional sediments, which facilitates the translocation of artifacts beyond original component boundaries and therefore obscures otherwise stratified deposits; the deflated nature of many upland settings; and the generally poor temporal resolution of diagnostic artifact types (Fields 1998). In general, however, the long Archaic of the region is characterized by the gradual emergence of strongly localized cultural traditions; overall reduction in annual and seasonal mobility; an apparent diversification of subsistence resources in response to increasing fluctuations of climate, available moisture, and plant and animal communities; and a corresponding diversification of regional artifact styles and technologies that were designed to exploit this quickly changing environment. The use of geophytes and hot rock cooking technology are a characteristic signature of seasonally occupied Archaic encampments in the Post Oak Savannah (Thoms 2008a). Sites such as Lambs Creek Knoll (41LN106), in Leon County, often contain mixtures of Late Paleoindian and Early Archaic cultural materials (Fields 1995, 2004), indicating the transitional nature of this time period. Common general Archaic dart point types include slender shouldered forms with definite stems, usually straight or parallel stems (Fields 2004:Figure 12.5). Many of these are crudely made and unidentifiable to a defined point type, although they presage more characteristic types found in Late Archaic (ca. 2000-200 B.C.) and Woodland period deposits, such as the Yarbrough, Dawson, Neches River, Gary, Kent, and Morrill types, among others (Fields 2004:Figure 12.8).

Adaptations resembling Woodland patterns appear not only in the East Central Texas by approximately 200 B.C., but also across the greater southeastern United States (Story 1990). This period in the Eastern Woodlands is characterized by the introduction of ceramics (in some areas); partial reliance on cultigens, particularly as a complement to seasonally available foraged foods; more prolonged stays at certain locales; social and ritual elaboration; and, later on (after ca. A.D. 700), the introduction of the bow and arrow. The adoption of ceramic technologies by the first millennium A.D. implies increasing emphasis on the cooking and storage of certain foodstuffs. Early vessels in East Texas Woodland sites (especially in the Sulphur and Red River basins) may be thick-walled and have only simple surface treatments, but this may not be the case in the Post Oak Savannah sites west of the Trinity River. Temper materials frequently utilized in Woodland sites include sand, bone, and crushed pottery (grog), although plain sandy paste pottery is present in Woodland period contexts in the Post Oak Savannah (Corbin et al. 1994; Fields 1995, 2004; Story 1990), along with possible early shell-tempered and kaolin paste pottery (Bruseth and Martin 1987; Fields 
2004:354; McGregor and Bruseth 1987). Gary points, with sharply triangular blades, contracting stems, and strong shoulders are perhaps the most common point type. Others include Godley, Kent, and Yarbrough (Fields 1995). Woodland adaptations are more clearly distinguished to the east of the study area, though many of the archaeological characteristics described are found in Leon County sites (Corbin et al. 1994; Fields 1995, 2004).

Late Prehistoric adaptations perhaps begin by approximately A.D. 800-900, and are immediately recognizable by the appearance of smaller arrow points on archaeological sites. Additional distinctive material culture remains include more elaborate decorations on the ceramics found on sites and a corresponding proliferation of types such as Crockett Curvilinear Incised/Pennington Punctated-Incised, Coles Creek Incised, Poynor Engraved, Killough Pinched, Maydelle Incised, Emory Punctated-Incised,

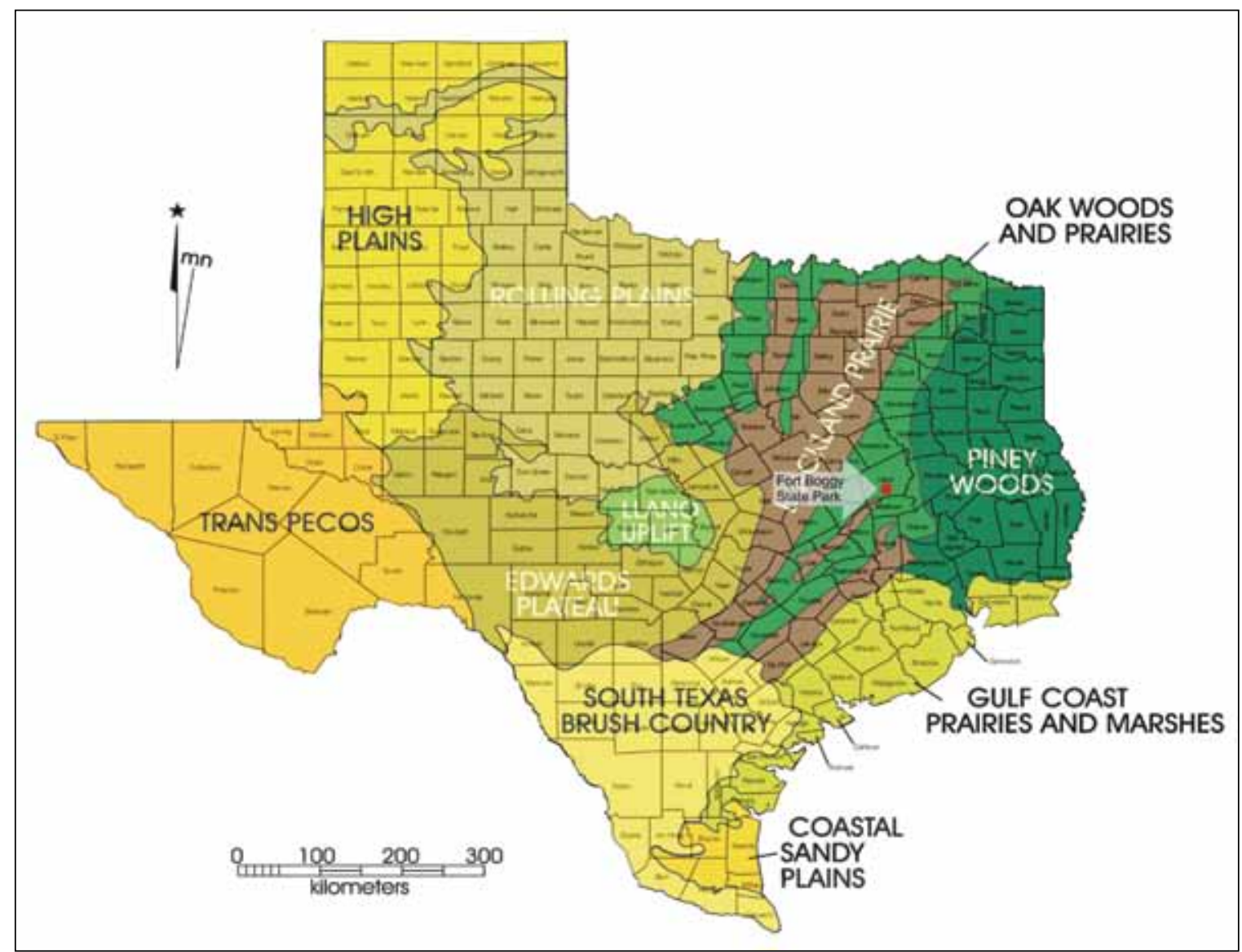

Figure 2. Map showing the location of Fort Boggy in the Post Oak Savannah of East Central Texas.

and Williams Plain (Fields 1995, 2004). Much of the pottery found on Late Prehistoric sites resembles the ceramics made by Caddo groups living mainly in the Neches-Angelina river basins in East Texas (Fields 1995, 2004; Gadus et al. 2002; Perttula 2009). This pottery may be the product of hunting and gathering activities of Caddo agriculturists, the actual settlement of Caddo peoples in the Post Oak Savanna west of the Trinity River (see Shafer 2007; Foster 2008), or the pottery represent local copies by non-Caddo peoples (Fields 1995:316). As Thoms (1997:23) notes, this part of the Post Oak Savannah in Leon County "lies along the western fringe or frontier of native agriculture as evidenced by archaeological data and the presence of 
Caddoan-speaking Tejas people in the area during the late 1600s and early 1700s."

The appearance of ritual paraphernalia or aesthetic objects such as bone or shell ornaments, beads, engraved pins, and so on in Caddo sites implies increasingly complex relationships within and between social groups living in the Caddo hinterlands and the Caddo's East Texas homelands (Story 1990; Foster 2008). Definite influences from the Caddo peoples living immediately to the east in the Neches River valley are noted during this time (especially before ca. A.D. 1300, see Shafer 2006), even if permanently occupied sites are not common (Fields et al. 1991; Gadus et al. 2002).

The Fort Boggy area was first settled by Anglo-Americans in 1839. An Indian ambush in February of 1840 led "to the construction of Fort Boggy for the protection and safety of the settlers. Named for its proximity to Boggy Creek, the fort consisted of two blockhouses with 11 dwellings inside a footprint of about 5,000 square feet. A military company...was formed to protect the fort under the leadership of Captain Thomas Greer. According to one account, 77 people moved into the fort upon its completion..." (National Park Service 2010:193-194).

In terms of the historical record, the study region is also well known for its robust record of late historical (late nineteenth to early twentieth centuries) rural settlement. This pattern includes tenant farmsteads, post-Civil War reconstruction and development, and gradual integration by railroad. Particularly in the early 1900s, there was a shift toward greater tenancy in small farm operators (Peck et al. 1996) as emancipated slaves and their immediate descendants, in addition to a lesser percentage of white farmers, remained somewhat tethered to agrarian production even as land ownership gradually transferred to predominantly white land owners. These small rural communities were often associated with poorly delineated historical cemeteries, many of which have been abandoned and have fallen into neglect. The Richland-Chambers Reservoir region, north of the study area (Bruseth and Moir 1987) on tributaries to the Trinity River, has been intensively investigated and offers one of the State's best records for late historical occupations. The park itself has a large number of late historical sites (Corbin et al. 1994), including homesteads, reflecting early twentieth-century tenant sharecropping and rural agricultural production. 


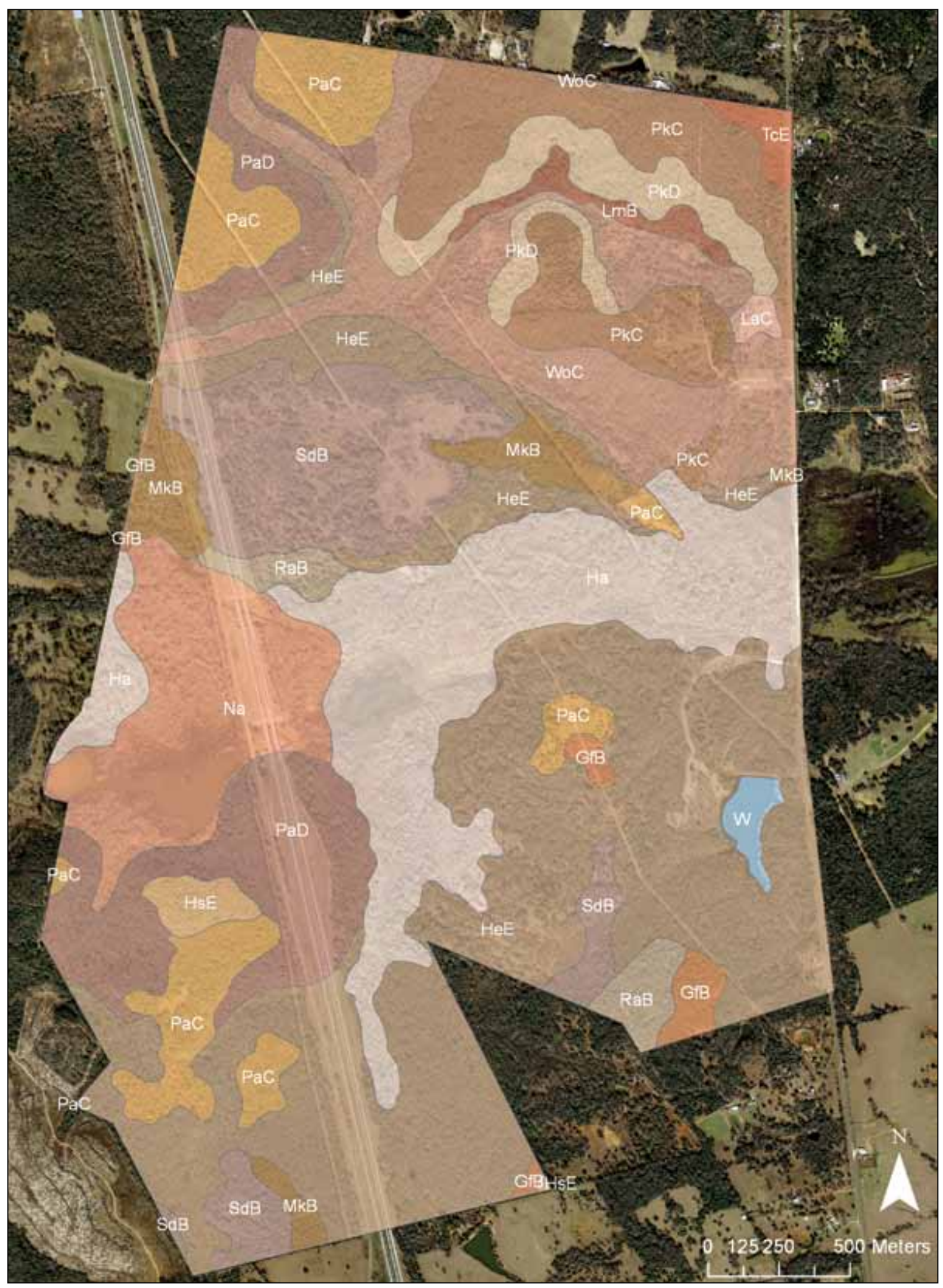

Figure 3. Distribution of soils within Fort Boggy State Park, Leon County, Texas. 



\section{Chapter 3}

\section{Survey methods}

CAS personnel proposed to revisit and update the condition of the 80 cultural resources sites that have been previously recorded in the Park (see Figure 1). With certain exceptions (Table 1), for each of the sites a minimum of eight shovel tests at least $35 \times 35 \mathrm{~cm}$ in size were excavated to the clay subsoil or to 1 meter below the modern ground surface (bs) when that subsoil could be reached. Shovel tests were excavated in a cruciform pattern across each site, with two sterile shovel tests in each cardinal direction identifying site boundaries, or less shovel tests if the landform extent (i.e., a gully or stream course) provided a better site boundary. In addition, a single $50 \times 50 \mathrm{~cm}$ test unit was excavated at each of the sites subjected to shovel testing to aid in identifying the depth and artifactual content of the archaeological deposits. The placement of this $50 \times 50 \mathrm{~cm}$ unit was determined by documented artifact densities from previously excavated shovel tests at the site, with the $50 \times 50 \mathrm{~cm}$ unit placed in an area within the site with the highest shovel testing artifact density. The presence of visible cultural features, as expected on a number of the historical sites that were shovel tested (cf. Corbin et al. 1994), was also taken into consideration when selecting $50 \mathrm{x} 50 \mathrm{~cm}$ unit placement on historical sites.

Table 1. List of previously recorded sites that will or will not be shovel tested at Fort Boggy State Park.

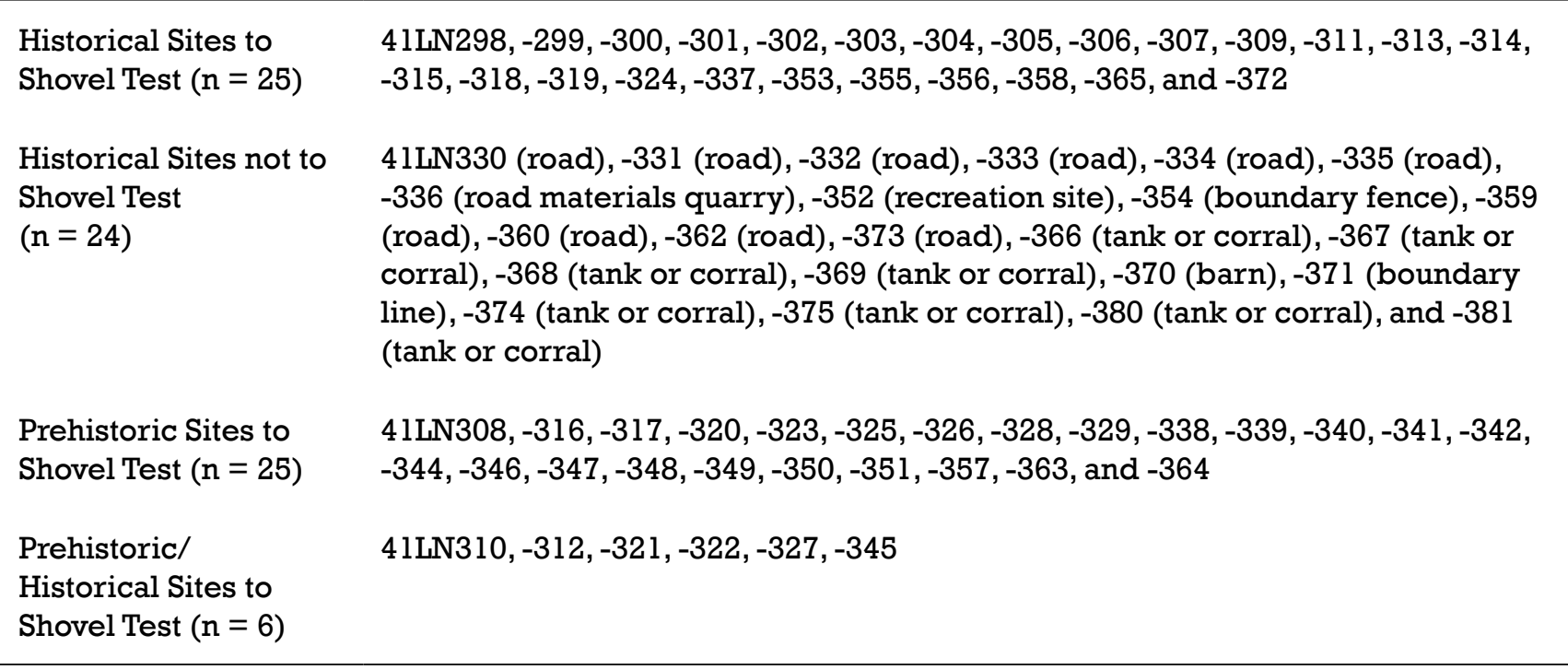

As Table 1 indicates, certain historical sites were not shovel tested, but only relocated and described. A number of historical sites were originally recorded as roads and road cuts, fence lines, corrals, cattle dipping tanks, and quarry materials (see Corbin et al. 1994). These sites were not shovel tested, but only recorded by GPS and photography so their current condition could be described for TPWD. In summary, there are 56 sites at Fort Boggy State Park that were proposed for archaeological investigation by shovel testing and the excavation of $50 \times 50 \mathrm{~cm}$ units (see Table 1). 


\section{Site Recording}

Each previously-recorded archaeological site identified in Table 1 as eligible for shovel testing will be fully recorded, with its areal extent; depth; artifactual content; and potential for eligible, intact deposits described. CAS shall complete a State of Texas Site Data Update Form for each site. Site Update forms shall be completed to TARL's satisfaction. Sites will be photographed to illustrate site setting. Sites not eligible for shovel testing will be mapped by GPS and a State of Texas Site Data Update Form will be filled out for each; each will also be photographed.

\section{Site Mapping}

Global Positioning System (GPS) equipment with sub-meter accuracy will be used to record all shovel tests and $50 \times 50 \mathrm{~cm}$ units When possible, GPS equipment will be employed to record polygons of site boundaries. In cases where site boundaries cannot be recorded in the field, polygons will be generated through post-field Geographic Information System (GIS) software, based on shovel testing results. Boundaries for historical homestead sites can be defined based on the presence of cultural landscape features, such as fence rows, wells, out buildings, etc., rather than relying on cruciform shovel testing. In cases where boundaries for these sites are not obvious, shovel testing should be used to define the boundaries. For prehistoric sites with obvious boundaries defined by natural features, such as the edge(s) of gullies or steep drainages, those boundaries will not be determined by shovel testing.

Site maps will be generated using Geographic Information System (GIS) software. Maps will depict all shovel tests, site boundaries, surface features, and landmarks.

Recommendations will be made for each site based on its perceived NRHP eligibility status as well as its potential for SAL designation. These recommendations will allow TPWD personnel to manage important resources while considering potential developments and improvements to park infrastructure.

Only artifacts (except burned rock and non-diagnostic modern materials, which shall both be quantified prior to on-site discard) recovered from manual excavations and diagnostics recovered from ground surface shall be collected and analyzed. Samples for radiocarbon dating or other dating procedures shall be collected where appropriate, but shall not be analyzed without the prior approval of the State.

The analysis of the recovered prehistoric and historical artifacts from the Park sites followed standard approaches in the identification of the age and presumed function of both prehistoric and nineteenth and twentieth-century material culture found on sites in East Texas. With respect to the few prehistoric artifacts (all chipped stone) that were recovered in the shovel testing and $50 \times 50 \mathrm{~cm}$ units (see below), they were separated into categories of unmodified lithic debris and chipped stone tools. The unmodified lithic debris was divided into cortical or non-cortical pieces, and further categorized as complete flakes (with bulbs of percussion) or flake fragments. In the case of the chipped stone tools, we recognized dart point and arrow point categories. Dart points are large bifacially-worked hafted tools with pointed distal ends, and probably mounted and propelled on an atlatl and spear. Arrow points are small (typically less than $5 \mathrm{~cm}$ in length) bilaterally symmetrical artifacts with a pointed distal end and some facility for hafting at the proximal end. Typological and chronological estimations for the recovered dart and arrow points follow Turner and Hester (1999) and Story (1990:Figure 32). 
The historical artifacts were sorted into broad classes by material culture categories-ceramics (refined earthenwares and stonewares), glass (bottle and fruit jar, as well as snuff and window glass), and metal-and further sorted by apparent function, such as clothing items (buttons), agricultural tools and implements, food and liquid containers and food serving ware (most of the bottle and jar glass and recovered sherds of whiteware, ironstone, and several kinds of stoneware), and architectural items (nails, bricks, and asphalt shingles). Establishing the ages of the historical artifacts-and the estimated age of the historical archaeological components at the sites-is primarily based on Majewski and O'Brien (1987) for the plain and decorated refined earthenwares; Greer (1981) and Lebo (1987) for stonewares; the Society for Historical Archaeology (2010) for glass bottles and jars; Meissner (1997) for buttons;Wells (2000) and Adams (2002) for square cut and wire nails; and Moir $(1987,1988)$ for window glass, based on changes in pane thickness.

CAS shall prepare all artifacts, records, and photographs for curation at the TPWD Archeology Laboratory. Materials shall be prepared in accord with the requirements of the current Texas Archeological Research Laboratory, The University of Texas at Austin guidelines and the TPWD Annual Texas Antiquities Permit. Any deficiencies in curation preparations shall be corrected by CAS at no additional cost to the State. Curation preparation may be completed at any time.

All reports, photographs, GPS and TDS data, maps, and GIS data shall be provided to TPWD at the time indicated below. All data shall be submitted on archival quality CD-ROM or DVD in a Windows format. All text shall be submitted in Microsoft Word format. All figures shall be submitted in high-resolution JPEG format. All tables shall be submitted in Microsoft Excel format. GIS data shall include uncorrected GPS data, conversion files, and corrected data in UTM (NAD83 CONUS, meters) coordinates. All corrected GIS data shall be submitted as ArcGIS shape files. 



\section{Chapter 4}

\section{Site Descriptions}

The site descriptions that follow rely on several sources of information. This includes the original 1992 site forms completed by Stephen F. Austin State University, as well as the information provided in Corbin et al. (1994:49-108, 109-142 and Tables 6-8), including site descriptions, artifact descriptions, site test information by site, and the provenience and number of artifacts of different categories recovered during that work. Finally, it includes relevant archaeological information obtained from the 2010 site relocation project at Fort Boggy State Park.

During the course of the archaeological investigations, a total of 915 shovel tests were excavated at Fort Boggy State Park to relocate and assess 56 of the 80 archaeological sites known in the Park (Table 2 and Figure 4); that is an average of 16.3 shovel tests per site selected for shovel testing (Figure 5). Approximately $29.4 \%$ of the excavated shovel tests contained either prehistoric or historical artifacts from depths as shallow as 5-10 cm bs to depths of more than $80-100 \mathrm{~cm}$ bs (Table 3); a number of the sites had $50 \times 50 \mathrm{~cm}$ units with deep deposits. The sites with deep archaeological deposits tend to date from what are thought to be Woodland (ca. 500 B.C.-A.D. 800) to Late Prehistoric (post-A.D. 800) times, or were occupied during an unknown part of prehistory.

Table 2. Shovel Testing on Fort Boggy State Park Sites.

\begin{tabular}{rcc}
\hline Site & $\begin{array}{c}\text { Total No. OF } \\
\text { ShOVEL TESTS }\end{array}$ & $\begin{array}{c}\text { Positive Shovel } \\
\text { TESTS }\end{array}$ \\
\hline $41 \mathrm{LN} 298$ & 12 & 3 \\
$41 \mathrm{LN} 299$ & 17 & 9 \\
$41 \mathrm{LN} 300$ & 12 & 5 \\
$41 \mathrm{LN} 301$ & 10 & 2 \\
$41 \mathrm{LN} 302$ & 12 & 4 \\
$41 \mathrm{LN} 303$ & 10 & 3 \\
$41 \mathrm{LN} 304$ & 10 & 2 \\
$41 \mathrm{LN} 305$ & 14 & 4 \\
$41 \mathrm{LN} 306$ & 9 & 6 \\
$41 \mathrm{LN} 307$ & 11 & 3 \\
$41 \mathrm{LN} 308$ & 52 & 28 \\
$41 \mathrm{LN} 309$ & 15 & 8 \\
$41 \mathrm{LN} 310$ & 23 & 4 \\
$41 \mathrm{LN} 311$ & 10 & 2 \\
$41 \mathrm{LN} 312$ & 13 & 5 \\
$41 \mathrm{LN} 313$ & 16 & 5 \\
$41 \mathrm{LN} 314$ & 18 & 8 \\
$41 \mathrm{LN} 315$ & 13 & 2 \\
$41 \mathrm{LN} 316$ & 16 &
\end{tabular}


Table 2, continued.

\begin{tabular}{|c|c|c|}
\hline Site & $\begin{array}{l}\text { Total No. of } \\
\text { Shovel Tests }\end{array}$ & $\begin{array}{c}\text { Positive Shovel } \\
\text { Tests }\end{array}$ \\
\hline 41LN317 & 18 & 2 \\
\hline $41 \mathrm{LN} 318$ & 13 & 4 \\
\hline $41 \mathrm{LN} 319$ & 18 & 9 \\
\hline 41LN320 & 12 & 2 \\
\hline 4lLN321 & 49 & 24 \\
\hline $41 \mathrm{LN} 322$ & 20 & 6 \\
\hline $41 \mathrm{LN} 323$ & 19 & 9 \\
\hline 41LN324 & 13 & 6 \\
\hline 41LN325 & 38 & 27 \\
\hline 41LN326 & 19 & 3 \\
\hline 41LN327 & 23 & 3 \\
\hline 41LN328 & 12 & 2 \\
\hline 41LN329 & 11 & 1 \\
\hline $41 \mathrm{LN} 337$ & 11 & 2 \\
\hline $41 \mathrm{LN} 338$ & 13 & - \\
\hline 41LN339 & 12 & 1 \\
\hline 4lLN340 & 26 & 3 \\
\hline 4lLN341 & 26 & 10 \\
\hline $41 \mathrm{LN} 342$ & 17 & 1 \\
\hline $41 \mathrm{LN} 343$ & 16 & 6 \\
\hline 41LN344 & 16 & 7 \\
\hline 41LN345 & 19 & 5 \\
\hline 4lLN346 & 13 & 1 \\
\hline $41 \mathrm{LN} 347$ & 11 & 3 \\
\hline $41 \mathrm{LN} 348$ & 17 & - \\
\hline 41LN349 & 20 & 2 \\
\hline $41 \mathrm{LN} 350$ & 14 & 1 \\
\hline 41LN351 & 18 & 1 \\
\hline 41LN353 & 10 & 3 \\
\hline 41LN355 & 15 & 6 \\
\hline $41 \mathrm{LN} 356$ & 14 & 5 \\
\hline 4lLN357 & 20 & 1 \\
\hline 41LN358 & 5 & 3 \\
\hline 41LN363 & 14 & 1 \\
\hline 41LN364 & 10 & 1 \\
\hline 41LN365 & 12 & 2 \\
\hline 41LN372 & 9 & 3 \\
\hline Totals & 915 & 269 \\
\hline
\end{tabular}




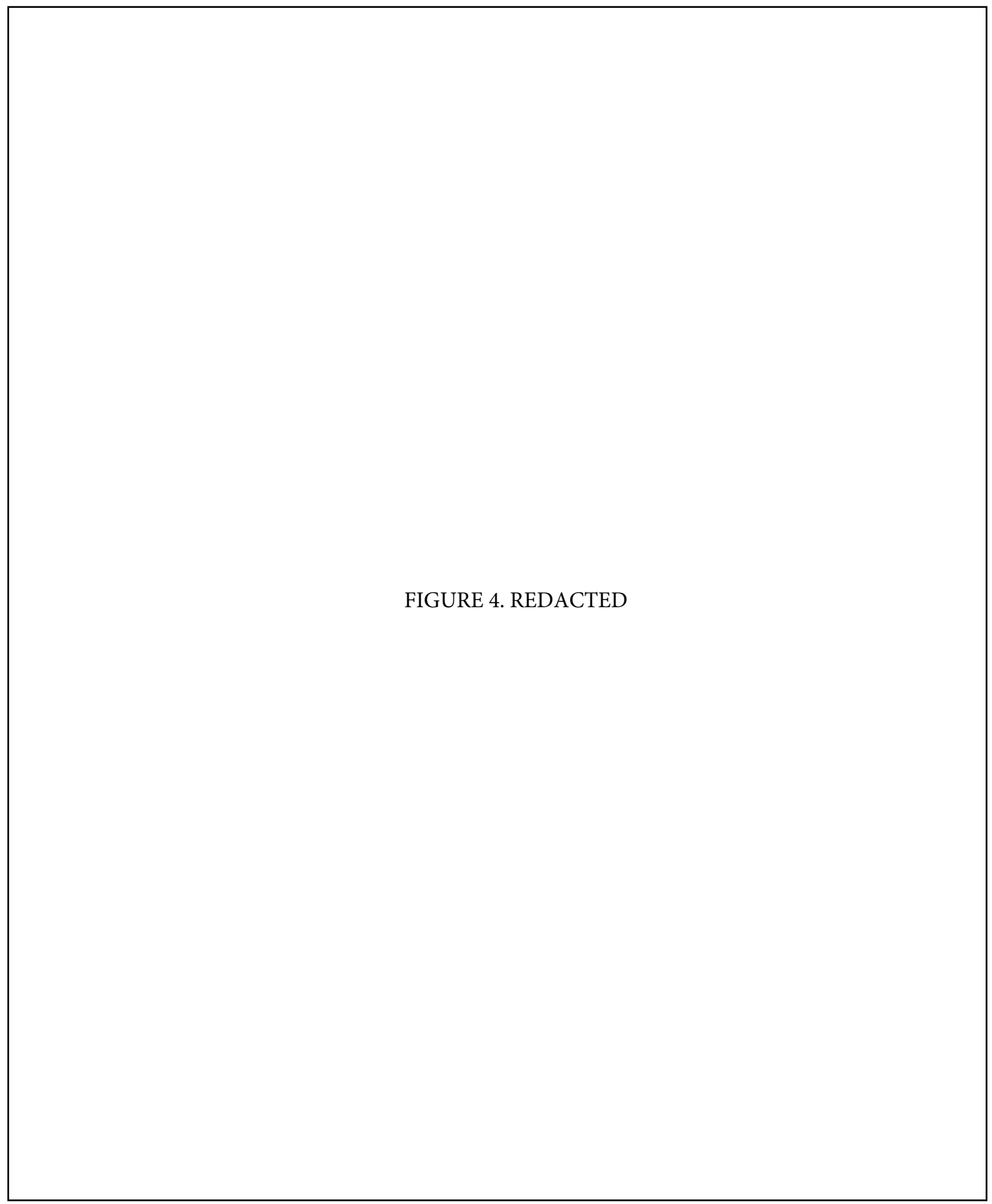

Figure 4. Sites that were shovel tested at Fort Boggy State Park. 
FIGURE 5. REDACTED

Figure 5. Graph showing frequency $(0-10,11-20,21-30,31-40,41-52)$ of shovel tests for Fort Boggy State Park sites that were shovel tested in 2010. 
Table 3. Sites with artifacts recovered in shovel testing and $50 \times 50 \mathrm{~cm}$ units at depths greater than $80 \mathrm{~cm}$ below surface.

\begin{tabular}{|c|c|c|}
\hline Site No. & $\begin{array}{c}\text { ARTIFACTS RECOVERED AT DEPTHS OF GREATER } \\
\text { THAN } 80 \text { CM BS }\end{array}$ & Site Age (PREHISTORIC ONLY) \\
\hline 4lLN299* & lithic debris, nutshell, charred wood & Prehistoric-Unknown \\
\hline 4lLN308 & $\begin{array}{l}\text { lithic debris, burned clay, nutshells, } \\
\text { wood charcoal, animal bone, fire- } \\
\text { cracked rock }\end{array}$ & Prehistoric-Woodland \\
\hline $41 \mathrm{LN} 310$ & lithic debris & Prehistoric-Woodland \\
\hline $41 \mathrm{LN} 314$ & bottle glass & Historic-nineteenth-twentieth C. \\
\hline $41 \mathrm{LN} 320$ & lithic debris & Prehistoric-Unknown \\
\hline $41 \mathrm{LN} 321$ & lithic debris, nutshell & Prehistoric-Woodland \\
\hline $41 \mathrm{LN} 323$ & $\begin{array}{l}\text { lithic debris, charred plant remains, } \\
\text { Gary point, burned clay }\end{array}$ & $\begin{array}{l}\text { Prehistoric-Woodland and Late } \\
\text { Prehistoric }\end{array}$ \\
\hline $41 \mathrm{LN} 325$ & $\begin{array}{l}\text { lithic debris, animal bone, nutshells, } \\
\text { ceramics; fire-cracked rock }\end{array}$ & $\begin{array}{l}\text { Prehistoric-Woodland and Late } \\
\text { Prehistoric }\end{array}$ \\
\hline $41 \mathrm{LN} 326$ & $\begin{array}{l}\text { lithic debris, fire-cracked rock, } \\
\text { nutshell }\end{array}$ & Prehistoric-Woodland \\
\hline $41 \mathrm{LN} 328$ & lithic debris & Prehistoric-Unknown \\
\hline $41 \mathrm{LN} 329$ & lithic debris & Prehistoric-Unknown \\
\hline $41 \mathrm{LN} 338$ & lithic debris & Prehistoric-Unknown \\
\hline 41LN339 & lithic debris & Prehistoric-Unknown \\
\hline $41 \mathrm{LN} 340$ & $\begin{array}{l}\text { lithic debris, fire-cracked rock, } \\
\text { nutshells }\end{array}$ & Prehistoric-Unknown \\
\hline $41 \mathrm{LN} 341$ & lithic debris & $\begin{array}{l}\text { Prehistoric-Woodland and Late } \\
\text { Prehistoric }\end{array}$ \\
\hline $41 \mathrm{LN} 343$ & $\begin{array}{l}\text { lithic debris, nutshells, burned clay, } \\
\text { tool fragment, charred wood }\end{array}$ & Prehistoric-Unknown \\
\hline $41 \mathrm{LN} 344$ & lithic debris, nutshell & Prehistoric-Unknown \\
\hline 4lLN345 & lithic debris & Prehistoric-Unknown \\
\hline 4lLN346 & lithic debris, wood charcoal & Prehistoric- \\
\hline $41 \mathrm{LN} 347$ & lithic debris & Prehistoric-Unknown \\
\hline $41 \mathrm{LN} 348$ & lithic debris, nutshells & Prehistoric-Unknown \\
\hline 4lLN350 & lithic debris & Prehistoric-Unknown \\
\hline 4lLN351 & lithic debris & Prehistoric-Woodland \\
\hline $41 \mathrm{LN} 358$ & lithic debris & Prehistoric-Unknown \\
\hline 4lLN364 & lithic debris & Prehistoric-Unknown \\
\hline
\end{tabular}

Three of the previously recorded sites at Fort Boggy State Park did not contain any artifacts in the intensive shovel testing (see Table 2). It is our opinion that the landforms upon which these sites were supposed to have been located (e.g., Corbin et al. 1994) were successfully identified and then thoroughly shovel tested (a $50 \times 50 \mathrm{~cm}$ unit was also excavated at each one of these locales). Following the completion of the $50 \times 50 \mathrm{~cm}$ units, each of these locations was found to contain archaeological materials, but they were 
especially sparse at 4 lLN315. The virtual absence of subsurface archaeological materials at this locale suggests that this locale does not contain sufficient artifacts to constitute an archaeological site.

A single $50 \times 50 \mathrm{~cm}$ test unit was excavated at 56 of the Fort Boggy sites (Table 4). Fifty-five of the sites encountered prehistoric and/or historical artifacts in these excavations; the archaeological recovery from the $50 \times 50 \mathrm{~cm}$ unit at $41 \mathrm{LN} 315$ is dubious, especially given the fact that none of the shovel tests excavated at the site contained any artifacts (see Table 2). Of the sites that had artifacts in the $50 \times 50 \mathrm{~cm}$ units, $34.5 \%$ had artifacts only from depths of less than $30 \mathrm{~cm}$ bs, while an equal proportion (34.5\%) had artifacts from depths greater than $80 \mathrm{~cm}$ bs.

Table 4. Results of the $50 \times 50 \mathrm{~cm}$ unit excavations at the Fort Boggy State Park sites.

\begin{tabular}{|c|c|c|c|}
\hline Site No. & $\begin{array}{c}\text { DEPTH OF } \\
\text { EXCAVATIONS } \\
\text { (CM BS) }\end{array}$ & $\begin{array}{c}\text { DEPTH OF ARCHAEOLOGICAL } \\
\text { DEPOSITS (CM BS) }\end{array}$ & $A_{g E}$ \\
\hline 41LN298 & 60 & $0-10$ and $30-40$ & $\mathrm{H}$ and $\mathrm{P}$ \\
\hline 41LN299 & 100 & $10-70,80-100$ & $P$ \\
\hline 4lLN300 & 67 & $0-30,40-50$ & $\mathrm{H}$ \\
\hline 41LN301 & 40 & $0-20$ & $\mathrm{H}$ \\
\hline 4lLN302 & 30 & $0-30$ & $\mathrm{H}$ \\
\hline 4lLN303 & 100 & $0-50$ & $\mathrm{H}$ \\
\hline 4lLN304 & 100 & $0-10$ & $\mathrm{P}$ \\
\hline $41 \mathrm{LN} 305$ & 30 & $0-20$ & $\mathrm{H}$ \\
\hline 4lLN306 & 12 & $0-10$ & $\mathrm{H}$ \\
\hline 4lLN307 & 25 & $0-20$ & $\mathrm{H}$ \\
\hline 41LN308 & 100 & $0-60,70-100$ & P-M \\
\hline 41LN309 & 40 & $0-40$ & $\mathrm{H}$ and $\mathrm{P}$ \\
\hline 41LN310 & 100 & $20-60,80-90$ & $P$ \\
\hline 4lLN311 & 44 & $0-44$ & $\mathrm{H}$ \\
\hline 41LN312 & 10 & $0-10$ & $\mathrm{H}$ and $\mathrm{P}$ \\
\hline 4lLN313 & 50 & $0-30$ & $\mathrm{H}$ \\
\hline 4lLN314 & 100 & $10-40,80-90$ & $\mathrm{H}$ and $\mathrm{P}$ \\
\hline 4lLN315 & 100 & $0-10$ & $\mathrm{H}(?)$ \\
\hline $41 \mathrm{LN} 316$ & 44 & $10-20,30-40$ & P-F \\
\hline 4lLN317 & 46 & $40-46$ & $P$ \\
\hline $41 \mathrm{LN} 318$ & 100 & $10-60$ & $\mathrm{H}$ \\
\hline 41LN319 & 30 & $0-20$ & $\mathrm{H}$ \\
\hline 4lLN320 & 100 & $0-20$ & $\mathrm{P}$ \\
\hline 41LN321 & 20 & $0-20$ & $\mathrm{P}$ \\
\hline $41 \mathrm{LN} 322$ & 50 & $0-10$ & $\mathrm{H}$ \\
\hline $41 \mathrm{LN} 323$ & 100 & $\begin{array}{l}10-60,70-80 \\
90-100\end{array}$ & $\mathrm{P}$ \\
\hline
\end{tabular}


Table 4, continued.

\begin{tabular}{|c|c|c|c|}
\hline Site No. & $\begin{array}{c}\text { DEPTH OF } \\
\text { EXCAVATIONS } \\
(\mathrm{CM} B S)\end{array}$ & $\begin{array}{c}\text { DePTH OF ARCHAEOLOGICAL } \\
\text { DEPOSITS (CM BS) }\end{array}$ & $A_{G E}$ \\
\hline 41LN324 & 50 & $0-50$ & $\mathrm{H}$ \\
\hline 4lLN325 & 100 & $0-100$ & P-M \\
\hline 4lLN326 & 100 & $50-70,80-90$ & $P$ \\
\hline 4lLN327 & 22 & 0-20 & $P$ \\
\hline 4lLN328 & 68 & $40-50$ & $P$ \\
\hline 41LN329 & 100 & $80-100$ & $P$ \\
\hline 4lLN337 & 30 & $0-10$ & $\mathrm{H}$ \\
\hline 4lLN338 & 100 & $20-40,90-100$ & $P$ \\
\hline 41LN339 & 100 & $90-100$ & $P$ \\
\hline 4lLN340 & 100 & $\begin{array}{l}10-20,30-40,50- \\
60,80-100\end{array}$ & $P$ \\
\hline 4lLN341 & 50 & $0-50$ & $P$ \\
\hline 4lLN342 & 70 & $40-70$ & $P$ \\
\hline $41 \mathrm{LN} 343$ & 100 & $10-100$ & $P$ \\
\hline $41 \mathrm{LN} 344$ & 100 & $20-30,80-100$ & $P$ \\
\hline $41 \mathrm{LN} 345$ & 100 & $0-60,70-80,90-100$ & $\mathrm{H}$ and $\mathrm{P}$ \\
\hline 4lLN346 & 100 & $90-100$ & $P$ \\
\hline 4lLN347 & 100 & $20-40,50-60,70-90$ & $P$ \\
\hline $41 \mathrm{LN} 348$ & 100 & $50-70,80-100$ & $P$ \\
\hline 41LN349 & 60 & $30-60$ & $P$ \\
\hline 41LN350 & 90 & $60-90$ & $P$ \\
\hline 4lLN351 & 92 & $0-10,80-92$ & $\mathrm{H}$ and $\mathrm{P}$ \\
\hline 4lLN353 & 100 & $0-30$ & $\mathrm{H}$ \\
\hline 4lLN355 & 30 & $0-30$ & $\mathrm{H}-\mathrm{M}$ \\
\hline 4lLN356 & 10 & $0-10$ & $\mathrm{H}$ \\
\hline 4lLN357 & 56 & $40-50$ & $P$ \\
\hline 4lLN358 & 100 & $0-20,60-70$ & $\mathrm{H}$ and $\mathrm{P}$ \\
\hline 4lLN363 & 40 & $30-40$ & $P$ \\
\hline 41LN364 & 100 & $90-100$ & $P$ \\
\hline 4lLN365 & 100 & $0-10$ & $\mathrm{H}$ \\
\hline 41LN372 & 60 & $0-60$ & H-M \\
\hline
\end{tabular}

$\mathrm{H}=$ historical (post-1840); H-M = historical-midden deposits; $\mathrm{P}=$ prehistoric; $\mathrm{P}-\mathrm{M}=$ prehistoric-midden deposits; $\mathrm{P}-\mathrm{F}=$ prehistoric with observed cultural feature

A variety of prehistoric $(n=1080)$ and historical $(n=1137)$ artifacts have been recovered from the Fort Boggy State Park sites from surface collections, extensive shovel testing, and the excavation of $50 \times 50 \mathrm{~cm}$ units. These will be discussed in detail in the site descriptions that follow, but this section provides a general summary of the findings adduced from the recovered prehistoric and historical artifacts at the park. 
Among the sites that contain prehistoric archaeological deposits ( $n=43$ sites), that primarily includes chipped stone tools, ground stone tools, and lithic debris; $59 \%$ of the recovered prehistoric artifacts are pieces of lithic tool from chipped stone tool manufacture and maintenance activities (Table 5). Twelve sites have fire-cracked rocks, indicating that minimally hot rock cooking of plant foods took place at these locales on the landscape. Five different sites, especially $41 \mathrm{LN} 308$ and the Black Finger Tip site (41LN325), have pieces of burned clay, these likely being the product of localized burning/heating in pits, ovens, and clay hearths.

Table 5. Prehistoric Artifacts from the Fort Boggy State Park Sites.

\begin{tabular}{|c|c|c|c|c|c|c|c|c|c|}
\hline Site & ToOLs & $\begin{array}{l}\text { LITHIC } \\
\text { DEBRIS }\end{array}$ & DS & PS & FCR & $\mathrm{BC}$ & $A B$ & WC/NS & $\mathrm{N}$ \\
\hline 41LN298 & - & 3 & - & - & - & - & - & - & 3 \\
\hline 4lLN299 & - & 22 & - & - & - & - & - & 16 & 38 \\
\hline 4lLN301 & - & 2 & - & - & - & - & - & - & 2 \\
\hline 41LN302 & - & 1 & - & - & - & - & - & - & 1 \\
\hline $41 \mathrm{LN} 303$ & - & 2 & - & - & - & - & - & - & 2 \\
\hline 4lLN304 & - & 3 & - & - & - & - & - & - & 3 \\
\hline 4lLN308 & 4 & 117 & 4 & 5 & 3 & 9 & 20 & 38 & 200 \\
\hline 4lLN309 & - & 2 & - & - & - & - & - & - & 2 \\
\hline $41 \mathrm{LN} 310$ & 1 & 33 & - & - & - & - & - & - & 34 \\
\hline 4lLN312 & - & 1 & - & - & - & - & - & - & 1 \\
\hline 41LN314 & - & 1 & - & - & - & - & - & - & 1 \\
\hline 4lLN316 & - & 7 & - & - & 1 & - & - & 5 & 13 \\
\hline 4lLN317 & - & 4 & - & - & - & - & - & 2 & 6 \\
\hline 41LN319 & - & 1 & - & - & - & - & - & - & 1 \\
\hline 4lLN320 & - & 3 & - & 1 & - & - & - & - & 4 \\
\hline 4lLN321 & 3 & 44 & - & - & 1 & - & - & 1 & 49 \\
\hline 4lLN322 & 1 & 2 & - & 1 & - & 1 & - & - & 5 \\
\hline $41 \mathrm{LN} 323$ & 1 & 40 & - & 1 & - & - & - & 4 & 46 \\
\hline $41 \mathrm{LN} 324$ & - & 1 & - & - & - & - & - & - & 1 \\
\hline 4lLN325 & 5 & 146 & 4 & 15 & 3 & 15 & 36 & 93 & 317 \\
\hline $41 \mathrm{LN} 326$ & - & 6 & - & - & 1 & - & - & 1 & 8 \\
\hline 41LN327 & - & 6 & - & - & - & - & - & - & 6 \\
\hline $41 \mathrm{LN} 328$ & - & 5 & - & - & - & - & - & - & 5 \\
\hline 41LN329 & - & 4 & - & - & - & - & - & - & 4 \\
\hline $41 \mathrm{LN} 338$ & - & 4 & - & - & - & - & - & 2 & 6 \\
\hline 4lLN339 & - & 2 & - & - & - & - & - & - & 2 \\
\hline 4lLN340 & - & 16 & - & - & 8 & - & - & 2 & 26 \\
\hline 4lLN341 & 1 & 51 & 1 & 5 & 2 & 1 & - & 1 & 62 \\
\hline 41LN342 & - & 5 & - & - & 8 & - & - & 2 & 15 \\
\hline
\end{tabular}


Table 5, continued.

\begin{tabular}{|c|c|c|c|c|c|c|c|c|c|}
\hline SITE & TOOLS & $\begin{array}{l}\text { LITHIC } \\
\text { DEBRIS }\end{array}$ & DS & PS & FCR & $\mathrm{BC}$ & $\overline{A B}$ & $\mathrm{WC} / \mathrm{NS}$ & $\mathrm{N}$ \\
\hline 41LN343 & - & 37 & - & 1 & 4 & 1 & 3 & 68 & 114 \\
\hline 41LN344 & - & 12 & - & - & - & - & - & 9 & 21 \\
\hline 41LN345 & - & 3 & - & - & 2 & - & - & - & 5 \\
\hline $41 \mathrm{LN} 346$ & - & 3 & - & - & - & - & - & 1 & 4 \\
\hline $41 \mathrm{LN} 347$ & 1 & 11 & - & - & 5 & - & - & - & 17 \\
\hline $41 \mathrm{LN} 348$ & - & 7 & - & - & - & - & - & 7 & 14 \\
\hline $41 \mathrm{LN} 349$ & 1 & 5 & - & - & 7 & - & - & 3 & 16 \\
\hline $41 \mathrm{LN} 350$ & - & 4 & - & - & - & - & - & - & 4 \\
\hline 4lLN351 & 1 & 5 & - & - & - & - & - & 3 & 9 \\
\hline 41LN357 & - & 5 & - & - & - & - & - & - & 5 \\
\hline 41LN358 & - & 2 & - & - & - & - & - & - & 2 \\
\hline $41 \mathrm{LN} 363$ & - & 3 & - & - & - & - & - & - & 3 \\
\hline $41 \mathrm{LN} 364$ & - & 2 & - & - & - & - & - & - & 2 \\
\hline 41LN372 & 1 & - & - & - & - & - & - & - & 1 \\
\hline Totals & 20 & 633 & 9 & 29 & 45 & 27 & 59 & 258 & 1080 \\
\hline
\end{tabular}

Dart points and arrow points were recovered at seven different sites. The dart points include a resharpened Early Archaic period Angostura point from 41LN308; single Late Archaic Bulverde and parallelstemmed points from $41 \mathrm{LN} 321$ and 4lLN349, respectively; a Woodland period Godley point from $41 \mathrm{LN} 308$ and a Woodland period Gary point preform from the Sweetgum site (4lLN323); and an unidentified dart point fragment from the Last Chance Quarry site (41LN341). Arrow points were only recovered at two sites, including a Late Woodland to Late Prehistoric (ca. A.D. 700-1000) Friley point from $41 \mathrm{LN} 310$ and a possible Perdiz point (dating ca. A.D. 1200 and after) from the Black Finger Tip site (41LN325).

Seven of the Fort Boggy State Park sites have prehistoric ceramic sherds (see Table 5). Six of the sites have plain sandy paste Goose Creek Plain, var. unspecified rim and body sherds: 41LN308, 41LN320, 4lLN322, the Sweetgum site (4lLN323), the Black Finger Tip site (4lLN325), and the Last Chance Quarry site (4lLN341). This ceramic type in this part of Texas was certainly made in pre-A.D. 800 Woodland period times (although it could also have continued to be made by Late Prehistoric inhabitants of the Texas Post Oak Savannah; the complete temporal range of this ceramic ware is not currently well established in this region). Work at the Gibbons Creek Lignite Mine in the Navasota River basin suggests that this sandy paste ware began to be made and used around A.D. 400 (Rogers 1991, 1993, 1994). The co-occurrence of Goose Creek Plain and Woodland period dart point types at 41 LN308 and the Sweetgum site (41LN323) lends further credence to the notion that these two sites, at least, have preserved Woodland period archaeological deposits.

Plain and/or decorated grog and bone-tempered Late Prehistoric (post ca. A.D. 800-900 Caddoaffiliated, although both bone and grog-tempered pottery dating after this time has also been found in coastal archaeological sites, see Ricklis [2004]) ceramic sherds have been recovered from four sites: 
41LN308, the Black Finger Tip site (4lLN325), the Last Chance Quarry site (4lLN341), and the Fern Slope site (4lLN343); only the Fern Slope site does not also have plain sandy paste Goose Creek sherds. Sherds from decorated grog and bone-tempered vessels have incised, engraved, brushed-incised, and brushed decorative elements that may be associated with occupations by Caddo peoples after ca. A.D. 1200, or the interaction of non-Caddo peoples in the Prairie Savannah with the East Texas Caddo; brushed utility ware jars began to be made by Caddo peoples in East Texas, particularly in the Neches and Angelina River basins, after ca. A.D. 1200-1250 (Perttula 2004).

Animal bones and charred plant remains (Carya sp. nutshells, acorn nut meat, black walnut nutshell, and hickory and oak wood charcoal, see Appendix 6) were recovered in three and 18 sites, respectively; they account for $25 \%$ of the recovered prehistoric artifacts from the Fort Boggy State Park sites. The majority of these preserved ecofacts are from prehistoric sites with midden deposits (41LN308 and the Black Finger Tip site, 4 lLN325), as well as at the Fern Slope site (4lLN343) (see Table 5), another important prehistoric site at Fort Boggy State Park.

Thirty-four different Fort Boggy State Park sites that we investigated in 2010 have historical artifacts (Table 6). These artifacts are almost exclusively from domestic farmstead components dating after the 1870s and 1880 s, although one small-scale brick kiln used for local brick manufacture was investigated at the Brick site (4lLN311). Given the nature of the domestic farmsteads, it is not surprising that the most common artifacts include bottle glass that held alcohol and medicines, snuff bottle glass, and fruit jar glass (including milk glass lid liners and zinc lids) for the preserving of food stuffs (35\% of the historical artifacts). Also common are cut and wire nails (28\% of the historical artifacts) from the construction of log cabins, wood framed houses, and wood outbuildings, window glass (from 13 sites), and sherds from refined earthenware plates, bowls, and cups and stoneware crocks and jugs (12\% of the historical artifacts).

Table 6. Historical Artifacts from the Fort Boggy State Park Sites.

\begin{tabular}{|c|c|c|c|c|c|c|c|c|c|c|}
\hline SITE & $\mathrm{C}$ & $\mathrm{N}$ & TIN $C_{A N}$ & $\mathrm{BT}$ & $\mathrm{BR}_{\mathrm{R}}$ & $\mathrm{M}$ & BF/FJG & WG & OT & $\mathrm{N}$ \\
\hline 4lLN298 & 1 & 3 & 1 & - & - & - & - & - & - & 5 \\
\hline 4lLN299 & - & 2 & - & - & - & 4 & 4 & 1 & - & 11 \\
\hline 4lLN300 & 1 & 65 & 1 & - & 4 & 2 & 7 & 3 & - & 83 \\
\hline 4lLN301 & 1 & 3 & - & 1 & - & - & - & - & - & 5 \\
\hline 4lLN302 & 2 & 4 & - & 1 & - & 2 & 1 & 1 & 1 & 12 \\
\hline 4lLN303 & 1 & 14 & - & - & - & - & 4 & - & - & 19 \\
\hline 41LN305 & 4 & 8 & - & - & - & - & 12 & - & - & 24 \\
\hline 4lLN306 & 15 & 3 & - & - & - & 3 & 30 & 6 & - & 57 \\
\hline 41LN307 & 12 & 18 & - & - & 2 & 1 & 73 & 10 & - & 116 \\
\hline 4lLN308 & 1 & - & - & - & - & - & - & - & - & 1 \\
\hline 4lLN309 & 13 & 32 & 1 & - & 3 & 10 & 32 & 5 & 7 & 103 \\
\hline \multicolumn{11}{|c|}{$\begin{array}{l}\text { C = ceramics; } N=\text { nails; Bt-button; } \mathrm{Br}=\text { brick fragments; } \mathrm{M}=\text { other metal (iron, lead, } \\
\text { and cupreous); BG = bottle glass, including snuff bottle glass; FJG = fruit jar glass, milk } \\
\text { glass lid liners, and zinc lids;WG = window glass; OT = other kinds of artifacts, including } \\
\text { a glass bead, gunflints, pieces of slate, animal bone, egg shell fragments, charred } \\
\text { nutshells/wood charcoal, a clay marble, tableware glass, thin wire, barbed wire, burned } \\
\text { clay/daub, and hard plastic. }\end{array}$} \\
\hline
\end{tabular}


Table 6, continued.

\begin{tabular}{|c|c|c|c|c|c|c|c|c|c|c|}
\hline SITE & $\mathrm{C}$ & $\mathrm{N}$ & TIN $C_{A N}$ & $\mathrm{BT}_{\mathrm{T}}$ & $\mathrm{B}_{\mathrm{R}}$ & $\mathrm{M}$ & BF/FJG & WG & OT & $\mathrm{N}$ \\
\hline 4lLN311 & - & - & - & - & 34 & - & - & - & - & 34 \\
\hline 4lLN312 & 10 & 1 & 11 & - & - & 1 & 3 & 5 & - & 31 \\
\hline $41 \mathrm{LN} 313$ & 3 & 7 & - & - & - & 3 & 6 & 5 & 1 & 25 \\
\hline $41 \mathrm{LN} 314$ & 4 & 2 & - & - & - & - & 10 & 1 & 1 & 18 \\
\hline 41LN315 & - & - & - & - & - & 1 & - & - & - & 1 \\
\hline 41LN318 & 2 & 10 & 2 & 1 & - & - & 14 & 3 & 2 & 34 \\
\hline 41LN319 & 9 & 6 & 5 & - & 1 & 1 & 7 & 5 & 6 & 40 \\
\hline $41 \mathrm{LN} 321$ & 2 & - & - & - & - & - & - & - & - & 2 \\
\hline 41LN322 & 10 & 16 & - & - & - & 3 & - & - & 2 & 31 \\
\hline $41 \mathrm{LN} 324$ & 19 & 42 & - & - & - & 4 & 45 & 6 & 2 & 118 \\
\hline $41 \mathrm{LN} 325$ & - & - & - & - & - & - & 3 & 1 & - & 4 \\
\hline $41 \mathrm{LN} 337$ & 3 & - & 1 & - & - & - & 2 & - & - & 6 \\
\hline 4lLN342 & 1 & - & - & - & - & - & - & - & - & 1 \\
\hline $41 \mathrm{LN} 345$ & 1 & 10 & - & - & 7 & 1 & 2 & - & 7 & 28 \\
\hline $41 \mathrm{LN} 347$ & - & 1 & - & - & - & - & - & - & - & 1 \\
\hline 41LN351 & - & - & - & - & - & 1 & - & - & - & 1 \\
\hline 4lLN353 & - & 21 & - & - & - & 1 & 96 & - & 1 & 119 \\
\hline 4lLN355 & 7 & 25 & - & 1 & - & 4 & 25 & - & 7 & 69 \\
\hline 4lLN356 & 7 & 8 & - & - & - & 2 & 8 & - & 1 & 26 \\
\hline 4lLN357 & - & 1 & - & - & - & - & - & - & - & 1 \\
\hline 4lLN358 & 3 & - & - & - & - & - & 1 & - & - & 4 \\
\hline 4lLN365 & - & 7 & 2 & - & - & - & - & - & - & 9 \\
\hline 41LN372 & 4 & 10 & - & - & 5 & 4 & 11 & - & 64 & 98 \\
\hline Totals & 136 & 319 & 24 & 4 & 56 & 48 & 396 & 52 & 102 & 1137 \\
\hline
\end{tabular}

$\mathrm{C}=$ ceramics; $\mathrm{N}=$ nails; $\mathrm{Bt}$-button; $\mathrm{Br}=$ brick fragments; $\mathrm{M}=$ other metal (iron, lead, and cupreous); BG = bottle glass, including snuff bottle glass; FJG = fruit jar glass, milk glass lid liners, and zinc lids;WG = window glass; OT = other kinds of artifacts, including a glass bead, gunflints, pieces of slate, animal bone, egg shell fragments, charred nutshells/wood charcoal, a clay marble, tableware glass, thin wire, barbed wire, burned clay/daub, and hard plastic.

There are also tin can fragments (at eight sites), clothing buttons, including buttons made from a cuprous material and milk glass (from four sites, see Table 6), hand-made and machine-made brick fragments (from seven sites), iron, lead, and cupreous artifacts, including farm implements as well as personal items (suspender attachments and a collar/cuff stud from 4lLN372). Finally, we recovered a glass bead from 41LN313, gunflints from 41LN322, pieces of slate, animal bone from a few sites, but not in great quantities, egg shell fragments (from 4lLN372), charred nutshells/wood charcoal, a clay marble from the Cedar House site (4lLN309), a molded stoneware pipe (4lLN324), tableware glass, thin wire, barbed wire, burned clay/daub (from 4lLN372), and a piece of hard plastic.

Artifacts that were particularly useful in attempting to establish the age of the historical occupations at Fort Boggy State Park included window glass, the thickness of which has chronological implications (see 
Moir 1987, and site descriptions below), the occurrence and ratio of cut to wire nails (cf. Adams 2002), the various kinds of decorated refined earthenwares and kinds of glazes on stoneware vessels, and hand-blown olive green bottle glass.

According to Adams (2002:Table 3), the ratio of wire to cut nails based on American nail production is an accurate measure of the likely age of historical sites with nails. Essentially, prior to 1886, only cut nails were in production, but by the early 1900 s, more than $90 \%$ of all nails being produced were wire nails. On sites with more than five nails, the proportion of cut nails (ranging from $0 \%$ to $100 \%$ ) from Fort Boggy sites indicates when they were likely to have been first occupied: Slimy Oak site (4lLN300, 1888, 77\% cut nails), the Well site (4lLN303,1893, 38\% cut nails), $41 \mathrm{LN} 305$ (post-1904, 0\% cut nails), $41 \mathrm{LN} 307$ (1899, 16.7\% cut nails), the Cedar House site (41LN309, 1897, 20.8\% cut nails), $41 \mathrm{LN} 313$ (post-1904, 0\% cut nails), the Black Walnut House (4 1LN318, post-1904, 0\% cut nails), $41 \mathrm{LN} 322$ (post-1904, 0\% cut nails), $41 \mathrm{LN} 324$ (1901, 14.7\% cut nails), $41 \mathrm{LN} 345$ (pre-1886, 100\% cut nails), $41 \mathrm{LN} 353$ (1915, 5\% cut nails), $41 \mathrm{LN} 355$ (1897, 20\% cut nails), $41 \mathrm{LN} 356$ (post-1904, 0\% cut nails), $41 \mathrm{LN} 365$ (post-1904, 0\% cut nails), and $41 \mathrm{LN} 372$ (pre-1886, 100\% cut nails).

Among the refined earthenwares from Fort Boggy State Park sites, one site had ca. 1780s-1830s pearlware (41LN321); all the other historical sites have whiteware, porcelain, or post-1850s ironstone sherds. The pearlware at $41 \mathrm{LN} 321$ suggests that some part of the historical occupation at $41 \mathrm{LN} 321$ may be associated with the earliest Anglo-American settlement (late 1830s) of the Fort Boggy area. Pre-1860s decorated ceramics include a blue shell-edged whiteware rim sherd from 41LN322, hand-painted whiteware sherds from the Cedar House site (4lLN309), $41 \mathrm{LN} 321$, and $41 \mathrm{LN} 322$, and a green transfer-printed sherd from the Cedar House site. Another sherd from the Cedar House site has a 1835-1853 Royal Arms maker's mark. Other pre-1860 ceramics include an interior/exterior salt-glazed stoneware sherd from $41 \mathrm{LN} 322$.

Later, in ca. post-1870 to early twentieth-century sites and occupations, there are distinctive stonewares, includes salt and lead-glazed, lead-glaze, and Bristol glaze sherds from a few sites, including 41 LN358. Among the decorated refined earthenware at the Fort Boggy State Park sites, there are post-1890 sherds with embossed and decalcomania decorations (cf. Majewski and O'Brien 1987:147, 154) at 4lLN307, the Halfway House site (4lLN312), 4lLN319, $41 \mathrm{LN} 324$, and $41 \mathrm{LN} 356$.

Pre-1880 hand-blown and applied lip olive green bottle glass has also been recovered at two Fort Boggy State Park sites: the Black Finger Tip site (4lLN325) and 4lLN345. The latter site also has an artifact assemblage with $100 \%$ cut nails, indicating an occupation that predated 1886.

\section{Historical Sites that Received Shovel Testing}

\section{LN298, Stone Cairn Site}

Corbin et al. (1994:54-55) identified this historical site as a "house site" on an upland landform (350 feet amsl) in the southwestern part of the Park. Its principal feature was a low mound (60 cm in height) of 55 rock ( $2 \times 0.9 \mathrm{~m}$ in size and $0.6 \mathrm{~m}$ in height) that apparently represents a fireplace or chimney foundation (Corbin et al. 1994:55); an elm tree was growing out of the rock pile. The site is cut by an old road bed section (41LN333), and immediately south of the old road bed are three large rocks that may represent stone piers to a structure. Corbin et al. (1994) state that one negative shovel test was excavated at the site, but the site 
form states no shovel tests were excavated; in any event, no artifacts were apparently recovered from the site and none were noted on the surface. Thus, the age of $41 \mathrm{LN} 298$ was not known, and its size was estimated at only $10 \mathrm{~m}$ in diameter.

The site was relocated through shovel testing $(n=12)$ in an area of hardwood trees and a thick understory of yaupon, holly, and mustang grapevines; surface visibility was less than $10 \%$. There were old road cuts (part of 4lLN333) to the north and south, and based on the shovel test, 4 lLN298 covers an estimated $900 \mathrm{~m}^{2}$ (0.2 acres) (Figure 6).

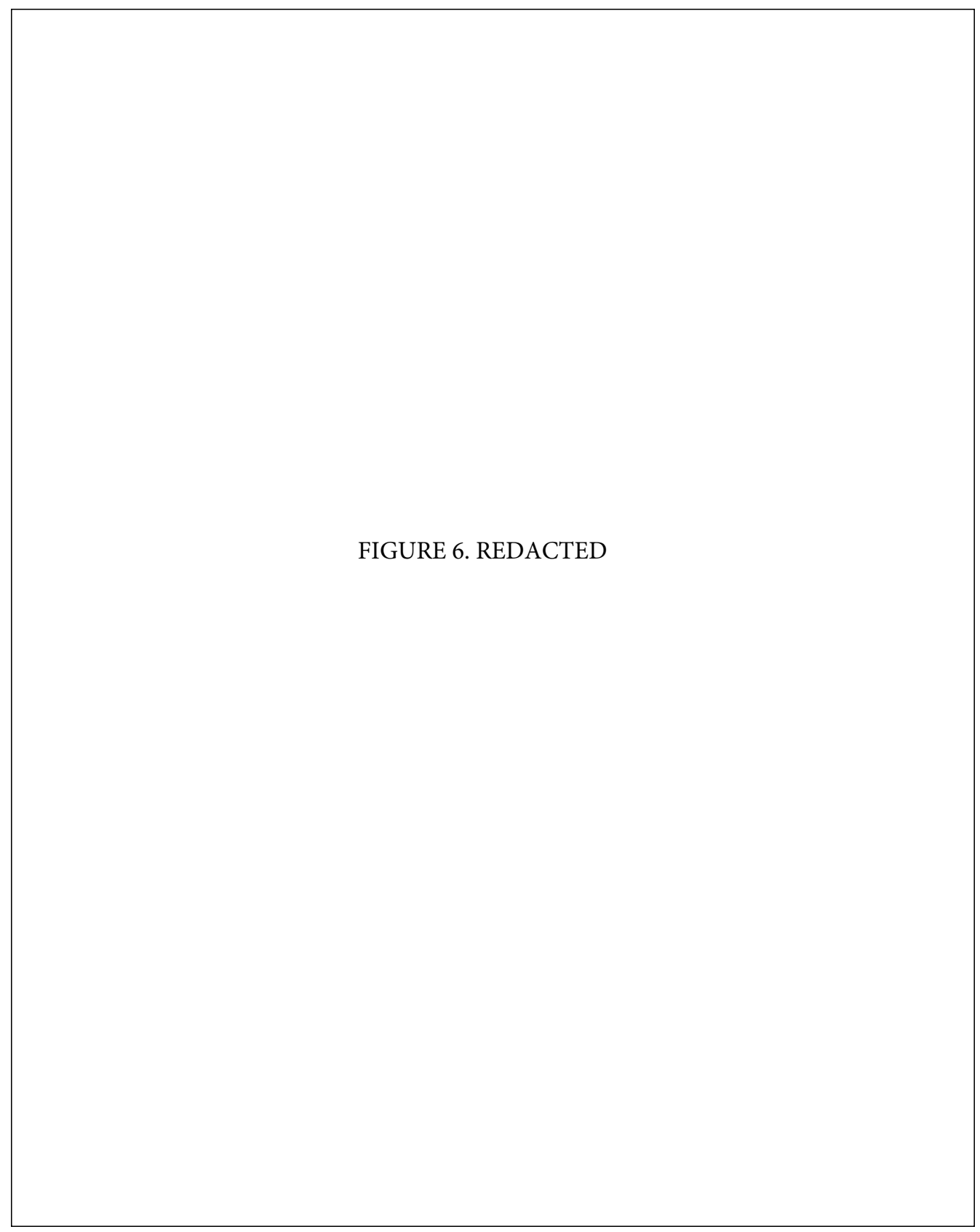

Figure 6. Map of $41 \mathrm{LN} 298$. 
The main feature on the site is a chimney foundation or seat ( $3.2 \times 1.5 \mathrm{~m}$ in length and width) constructed from tabular sandstone rocks stacked two or three rocks in height (approximately $40 \mathrm{~cm}$ ), and visible at the surface. An elm tree has taken root in the feature, and is likely to continue to displace the alignment of the rocks in it.

In these investigations, both prehistoric and post-1890 historical artifacts were recovered in shovel tests and the $50 \times 50 \mathrm{~cm}$ unit (see Appendix 3). The prehistoric artifacts, found at $20-70 \mathrm{~cm} \mathrm{bs}$, include three pieces of lithic debris from two shovel tests (ST 687 and ST 690) at either end of the site and Unit 298, in the central part of the site (see Figure 6). Prehistoric artifact density is 1.0 per positive shovel test (ca. 8 artifacts per $\mathrm{m}^{2}$ ), but the density is only 4 artifacts per $\mathrm{m}^{2}$ in the $50 \times 50 \mathrm{~cm}$ unit. All three pieces are non-cortical, and are of gray chert $(n=1)$, grayish-brown chert $(n=1)$, and a heat-treated quartzite.

The historical artifacts are from ST 686 and ST 691 (0-40 cm bs), as well as from 0-10 cm bs in Unit 298 (see Figure 6). They include two wire nails, an unidentifiable nail shank, a tin can fragment, and a plain whiteware sherd. The wire nails indicate the occupation took place after ca. 1890 (cf.Wells 2000). The historical artifact density in the shovel tests is 1.5 per positive shovel test (ca. 12 artifacts per $\mathrm{m}^{2}$ ), and only 8 artifacts per $\mathrm{m}^{2}$ in the $50 \times 50 \mathrm{~cm}$ unit, suggesting the historical use of the Stone Cairn site was not a lengthy or intensive one.

\section{LN299}

This site was thought to be an early twentieth-century house site that was bisected by an historical road bed (4lLN333) (Corbin et al. 1994:56). The site, as recorded, was about $25 \mathrm{~m}$ in diameter and located on a narrow upland ridge (365 feet amsl), and had a scatter of pre-1920s car parts, plow parts, bucket fragments, and brick fragments. There also were two brick piers from a structure; both were made from Mexia Standard (ca. 1921-1930) bricks. Three shovel tests were excavated at 41 LN299 by Corbin et al. (1994), but none contained any historical artifacts.

$41 \mathrm{LN} 299$ is located not far to the southwest of the Stone Cairn site (4lLN298), being situated on a long $(200 \mathrm{~m})$ and relatively narrow upland ridge (350-360 ft. amsl) landform (Figure 7). The ridge is covered in hardwood trees, with an understory of holly and grapevines.

In our investigations, we recovered both prehistoric and historical artifacts from spatially nonoverlapping components. The prehistoric component, of an unknown age, extends from the central and broader part of the upland ridge to its southern end, at the location of ST 714 (see Figure 7) The $50 \times 50 \mathrm{~cm}$ unit was placed in the area of the prehistoric component. The historical component is situated on the central part of the ridge, and the northern end of the site (see Figure 7), and is in a clearing ca. $40 \mathrm{~m}$ in diameter. Shovel testing on the site $(n=17)$ indicates that $41 \mathrm{LN} 299$ overall covers a $6000 \mathrm{~m}^{2}$ area $(1.5$ acres $)$, much larger than the Corbin et al. (1994) site size estimate.

The prehistoric artifacts from $41 \mathrm{LN} 299$ consist of lithic debris, nutshell $(\mathrm{n}=10)$, and pieces of wood charcoal ( $n=6)$ from five shovel tests (ST 699-702 and ST 714) and Unit 299 (see Figure 7). These occur at depths of 0-100 cm bs. The density of prehistoric artifacts in shovel tests is 2.4 per positive test or 19.2 artifacts per $\mathrm{m}^{2}$. The highest density is in ST 700 (40.0 artifacts per $\mathrm{m}^{2}$.) In the $50 \mathrm{x} 50 \mathrm{~cm}$ unit placed next to ST 700, the artifact density was even higher, at 104 artifacts per $\mathrm{m}^{2}$; the artifacts were concentrated in the 50$70 \mathrm{~cm}$ bs levels, suggesting that the prehistoric materials may be at least in part buried by overlying loamy fine sand deposits. 
FIGURE 7 REDACTED

Figure 7. Map of 41 LN299. 
The lithic debris came from the knapping of several different lithic raw materials. These include: locally available petrified wood ( $n=9 / 22 \%$ cortical), and locally available quartzite ( $n=8 / 50 \%$ cortical), reddish-brown chert ( $n=1 / 0 \%$ cortical), light gray chert $(n=1 / 0 \%$ cortical), and gray chert $(n=3 / 33 \%$ cortical). The proportions of cortical flakes-all from pebbles or cobbles gathered in stream gravels, based on smoothed, stream-rolled cortical surfaces-suggests that raw materials were gathered at a gravel source and knapped on site to produce bifacial tools or flake tools.

The historical artifacts from $41 \mathrm{LN} 299$ were recovered from four shovel tests (ST 698, 704, 705, and 708), from depths of 0-60 cm bs. The density is 2.5 historical artifacts per positive shovel tests, or 20.0 artifacts per $\mathrm{m}^{2}$. These artifacts include two wire nails (post-1891) used on a wood-framed structure, an aquacolored window glass sherd (thickness of $2.28 \mathrm{~mm}$, indicating a manufacture date of $1904.7 \pm 7$, see Moir 1987), a tin can fragment, two clear glass bottles and one clear glass sherd, and three pieces of iron. Brick fragments marked with the MEXIA \& STANDARD label are strewn across the historical area, 6-10 m north of a sandstone pier, and there are Model $\mathrm{A}$ car body and parts visible a short distance north of the defined site boundaries (see Figure 7), but may be associated with the historical farmstead occupation.

The clear bottle glass bottles and sherds at $41 \mathrm{LN} 299$ are from post-1905 modern machine-made bottles with visible mold lines. The whole bottle from ST 705 is a one pint ( $9 \mathrm{oz}$ ) bottle with a lip thread (Figure 8a). There are impressed diamonds on the sides of the bottle, and the base is also embossed. The embossing on the base (an $\mathrm{H}$ over an $\mathrm{A}$ ) indicates it was made by the Hazel-Atlas Glass Company (Wheeling, West Virginia) sometime after 1923 (www.myinsulators. com/glass-factories/bottlemarks2.html, accessed April 13, 2011). The second bottle is a post-1905 bottle made by the Owens Bottle Co. between 1919 and 1930 (Figure 8b). It has a Box O embossed on the base (Lockhart et al. 2010).

The iron pieces appear to be related to farm activities. One is a cinch style iron buckle (ST 708), another piece with bolt holes may be a wagon part or a plow part (ST 705), and the iron may be an iron barrel hoop (ST 698).

\section{LN300, Slimy Oak Site}

$41 \mathrm{LN} 300$ was initially recorded as a late nineteenthcentury house site (an estimated $20 \mathrm{~m}$ in diameter) adjacent to an historical road bed (41LN333), and situated on an upland landform (350 feet amsl). Noted on the site during the 1990s work was a fireplace foundation of ferruginous sandstone rocks, and rock piers and a rectangular mounded area for a structure platform; a second rock fireplace may be present on the southeast side of the pier foundation (Corbin et al. 1994:56-57). These features could not be discerned during the 2010 work.

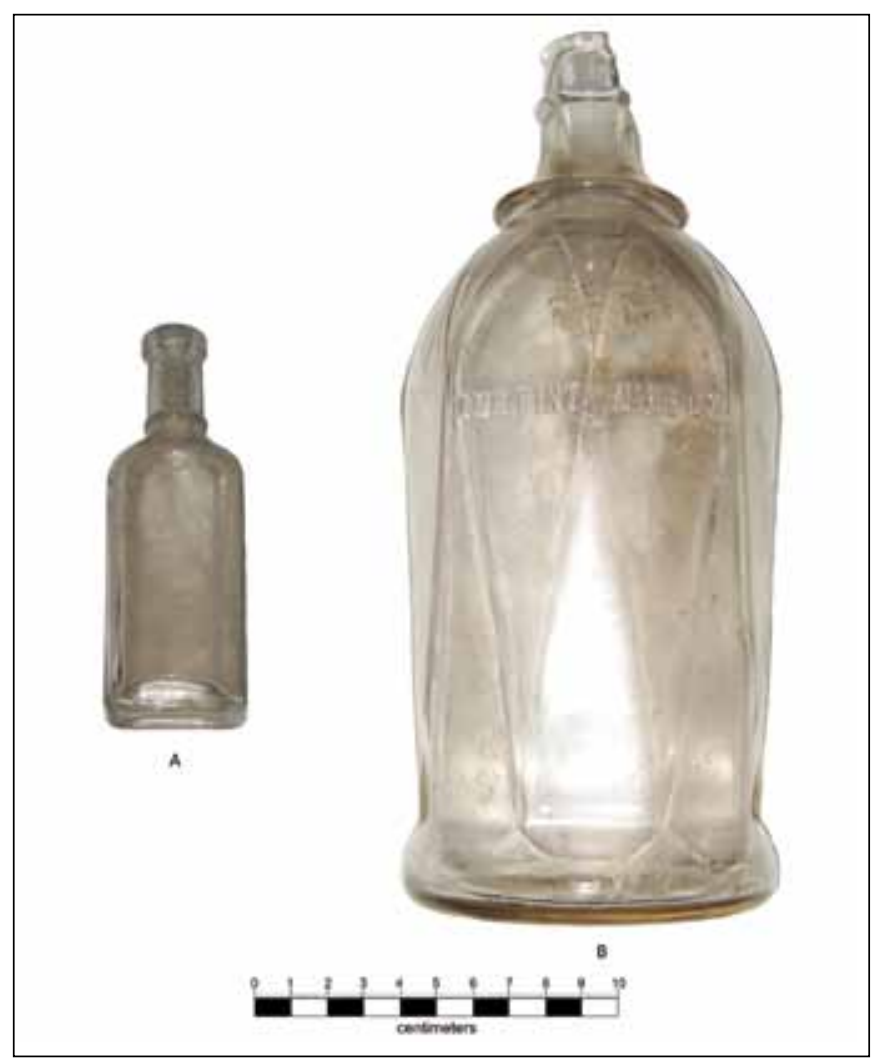

Figure 8. Clear glass bottles from 41 LN299: a, Clear bottle made by the Hazel-Atlas Glass Company; b, Clear bottle made by the Owens Bottle Co. 
Found associated with these features were locally-made bricks and brick fragments $(n=1)$, cut nails ( $n=9,1820-1891$, Wells 2000), wire nails ( $n=3$, post-1891), and glass sherds $(n=3$, including one window glass or flat glass sherd) in four shovel tests (Corbin et al. 1994:Tables 6 and 8). The archaeological deposits occurred at a depth range of $46-77 \mathrm{~cm}$ bs.

The Slimy Oak site was relocated during 2010 shovel testing as being situated along the edge of an old pasture, and between the Stone Cairn site (4lLN298) and 4lLN299, on an upland landform (350 ft. amsl) (Figure 9). The site is bisected by two old road cuts. The landform has a hardwood overstory with an understory of yaupon holly and mustang grapevines; surface visibility was less than $10 \%$.

The site was first noted because of possible sandstone piers and a stacked brick and tabular sandstone pile over a ca. 3 x $1.5 \mathrm{~m}$ area that may be part of a chimney foundation or seat. Shovel tests around these

FIGURE 9 REDACTED

Figure 9. Map of the Slimy Oak site (41 LN300). 
features indicate that the archaeological deposits covered a significantly larger area than indicated by Corbin et al. (1994), namely $3000 \mathrm{~m}^{2}$ (0.74 acres) (see Figure 9).

The historical artifacts recovered from the Slimy Oak site during the recent archaeological investigations came from five shovel tests and Unit 300 (see Figure 9); other artifacts were noted on the surface. The artifacts were found at $0-60 \mathrm{~cm}$ bs, but the majority of the artifacts were found at $0-40 \mathrm{~cm}$ bs. The density of historical artifacts in the shovel tests is 4.8 per positive shovel test, or 38.4 artifacts per $\mathrm{m}^{2}$. In Unit 300 , the density is 232 artifacts per $\mathrm{m}^{2}$, mostly nails. The highest densities of artifacts in the shovel tests are in ST 717 and ST 721. The Slimy Oak site artifacts are dominated by nails, with a few other domestic artifacts (bottle glass sherds, fruit jar milk glass, snuff jar sherds, whiteware sherds, tin can fragments) and hand-made brick fragments. historical artifacts on the surface include whole and fragmentary bricks, a rusted metal bucket, and an iron plow point.

The nails from the site are dominated by cut nails $(1820-1891, n=44)$, although there are a few wire nails (post-1891, $\mathrm{n}=13$ ) in the assemblages. The proportion of cut to wire nails ( $77 \%$ cut nails) suggests an occupation that took place in the late 1880s (cf. Adams 2002), and that a wood-framed house had been built on the site. There are also a few unidentified nail shanks $(n=8)$. Window glass $(n=3)$ from ST 717 and Unit 300 indicates the structure had windows and window panes. The mean thickness of the window glass (2.22 $\mathrm{mm}$ ) suggests that the panes were manufactured ca. 1899.7 \pm 7 years. (see Moir 1987).

Bottle glass sherds are from clear $(n=1)$, aqua $(n=2)$, and brown $(n=2)$ colored bottles. There was a brown snuff glass lid sherd from Unit 300, and a sherd from a late nineteenth-early twentieth-century fruit jar white milk glass lid liner (ST 718). Other domestic goods in the assemblage include a whiteware base sherd (ST 715), and a tin can fragment (ST 722). Iron artifacts include a washer (ST 721) and a piece of iron chain link (Unit 300, 0-10 cm bs).

There were two kinds of bricks from Unit 300 and ST 721. The first is a red (2.5YR 5/8) oxidized brick with manganese inclusions, while the second kind is a reddish-brown (2.5YR 5/3) with heavy manganese blooms visible in the paste. Both are probably from local brick-making kilns. One complete brick of the latter kind measured 7.75 inches in length, 3.875 inches in width, and 2 inches in thickness.

\section{$41 L N 301$}

Corbin et al. (1994:57) identified this site as an historical site, probably dating to the late nineteenth century on the basis of one cut nail found on the surface, on a small west-facing natural rise and toe slope (310 feet amsl) $75 \mathrm{~m}$ east of an intermittent tributary to Boggy Creek. The site was an estimated $20 \mathrm{~m}$ in diameter, and was situated between two sections of an old road bed (4lLN333). The principal feature on the site was a low rock square mound of stacked rocks $(1.9 \times 1.8 \mathrm{~m}$ in length and width, and $0.4 \mathrm{~m}$ in height) that appeared to be a fireplace or chimney foundation. Two shovel tests were excavated at $41 \mathrm{LN} 301$ at that time, but both were negative (Corbin et al. 1994:57); the site form states that no shovel tests were excavated, however.

In 2010, the site was relocated through shovel testing $(n=10)$ on the western edge of an upland toe slope, adjacent to an intermittent stream that still had pools of water in the summer (Figure 10). The site has an overstory of hardwoods with an understory of huckleberry trees; surface visibility is less than $10 \%$.

The main feature on the site was the previously mentioned mound of stacked sandstone rocks that was apparently part of a rock chimney foundation (1.2 x $1.6 \mathrm{~m}$ in length and width); a huckleberry tree is 


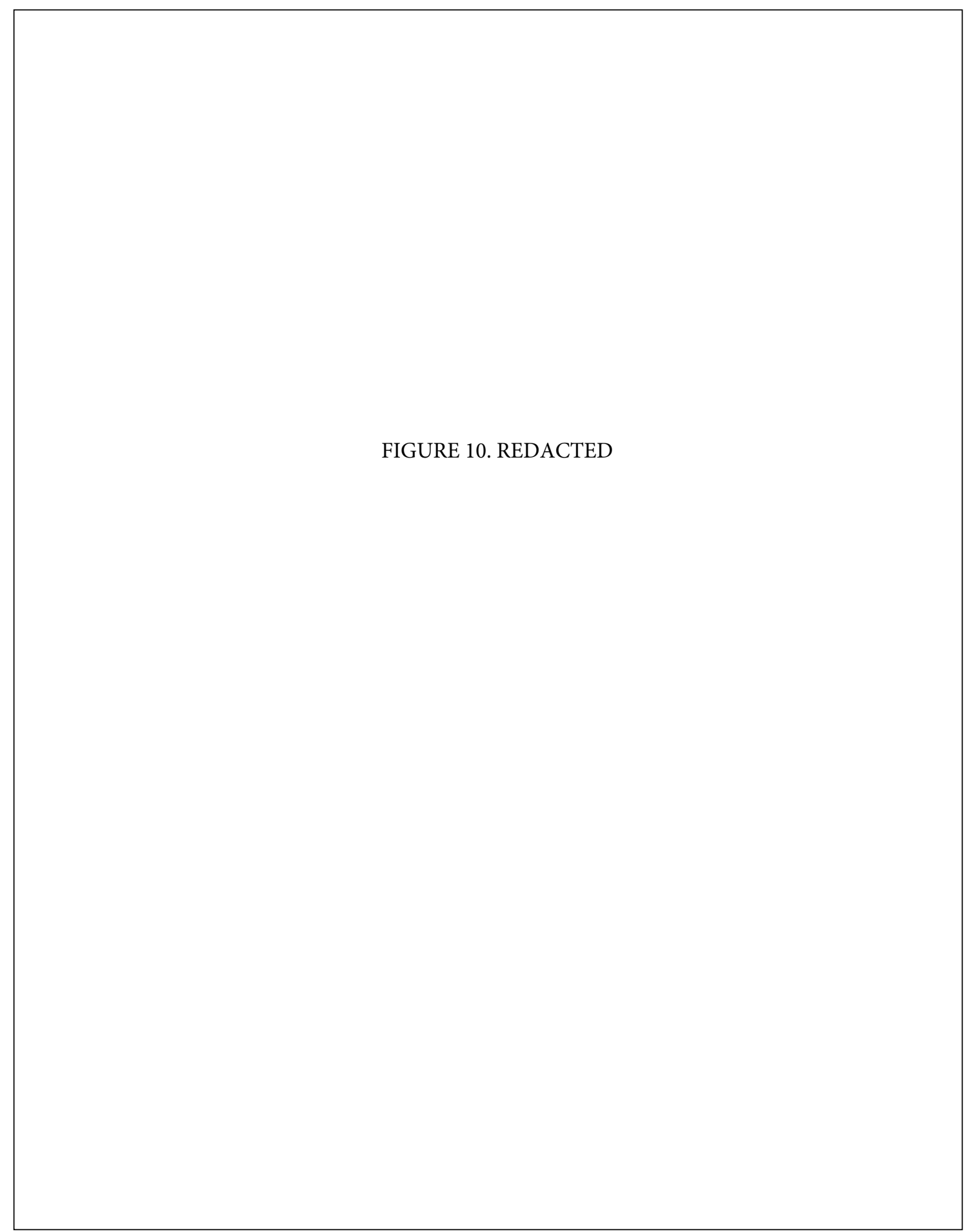

Figure 10. Map of 41 LN301.

growing in the rock feature. The mound stands $40 \mathrm{~cm}$ in height. It is in the northern part of the site, and there is an associated scatter of sandstone rocks north, west, and south of the chimney mound (see Figure 10). 4 lLN301 is estimated to cover a ca. $20 \times 20 \mathrm{~m}$ area (0.1 acres) of the landform. 
In our work, both prehistoric and historical artifacts are present in the archaeological deposits incorporated in the Padina loamy fine sand soil. The prehistoric artifacts, of unknown age, are from one shovel test (ST 744, 20-31 cm bs) (see Figure 10), and include two pieces of non-cortical lithic debris: local petrified wood $(n=1)$ and gray chert $(n=1)$. The prehistoric artifact density in this shovel test is 16 per $\mathrm{m}^{2}$, but the distribution of these remains are very limited at the site.

The historical artifacts are from one shovel test (ST 751, 0-20 cm bs) and Unit 301 (0-20 cm bs) (see Figure 10). These artifacts include two wire nails, an unidentifiable nail shank, a plain porcelain body sherd, and a cupreous overall button with a central hole; "LONE STAR" is embossed on the outside of the button. These materials suggest that 4 lLN301 was occupied after ca. 1890, based on the recovery of several wire nails. The historical artifact density in the shovel tests is 1.0 per positive shovel test, or 8 per $\mathrm{m}^{2}$, while the density in the $50 \times 50 \mathrm{~cm}$ unit is 16 artifacts per $\mathrm{m}^{2}$

\section{$41 L N 302$}

4lLN302 was described as a small (20 $\mathrm{m}$ in diameter) historical house site on a southeast-facing upland slope (340 feet amsl) by Corbin et al. (1994:57-58). The recovery of both cut nails $(n=3)$ and transferprinted whiteware sherds $(n=1)$ from two shovel tests suggested the site may have been occupied prior to 1860; other recovered material culture remains included vessel glass and animal bones. The area where the artifacts were present was marked by a soil discoloration, suggesting yard trash midden deposits may have been present at the site. The site was along a section of an historical road bed (41LN333), and was also marked by a rock fireplace foundation ( $2.5 \times 1.5 \mathrm{~m}$ in size). Southwest of the rock fireplace was a rectangular pattern of smaller rocks (less than $40 \mathrm{~cm}$ in size) that may mark the piers to a rock structural foundation (Corbin et al. 1994:57).

The site when relocated in 2010 was marked by scatters and piles of sandstone rocks in the southern part (Figure 11), but the rock piers to a structure foundation noted in Corbin et al. (1994) could not be identified. The site has an overstory of hardwood trees with an understory of huckleberry and mustang grapevines; surface visible was less than $10 \%$.

Based on shovel testing on the upland landform $(n=12), 41 \mathrm{LN} 302$ covers approximately $1400 \mathrm{~m}^{2}(0.34$ acres). An old road cut parallels the site boundary on the south, with a small stream lying $60 \mathrm{~m}$ farther to the south (see Figure 11). The possible rock chimney remains north of ST 302 measure ca. $1.8 \times 1.1 \mathrm{~m}$.

During our 2010 investigations four shovel tests and Unit 302 contained historical artifacts in archaeological deposits in Padina loamy find sand sediments a maximum of $40 \mathrm{~cm}$ in thickness (see Figure 11). Unit $302(0-10 \mathrm{~cm}$ bs) also had a single prehistoric quartzite non-cortical piece of lithic debris, indicating a transitory use of the landform at some unknown time in the prehistoric era.

The density of historical artifacts at 4 lLN302 is 1.75 per positive shovel test, or 14.0 artifacts per $\mathrm{m}^{2}$. ST 681 has the highest artifact density of the positive shovel tests. In Unit 302, the density is 20.0 artifacts per $\mathrm{m}^{2}$.

The recovered artifacts include both domestic and architectural remains, as well as a few miscellaneous artifacts. These include a 4-hole shirt/dress ceramic or "milk glass" button (cf. Meissner 1997:120), a plain porcelain base sherd, a plain ironstone rim sherd, an olive green wine bottle sherd, a piece of slate, cut nails $(n=2)$, wire nails $(n=1)$, unidentified nail shanks $(n=1)$, aqua-colored window glass $(n=1)$, iron fence staples $(n=1)$, and a piece of lead. 
FIGURE 11. REDACTED

Figure 11. Map of 41 LN302. 
The range of artifacts found at $41 \mathrm{LN} 302$ suggest that the historical occupation here began sometime after 1850 until about the 1890s, and was not just occupied before 1860 as Corbin et al. (1994) had suggested. This includes the ceramic button (ca. 1850-1910), cut (1820-1891) and wire nails (post-1891), and the window glass sherd. The thickness $(2.10 \mathrm{~mm})$ of the window glass sherd from ST 681 suggests it came from a window glass sheet manufactured ca. $1889.6 \pm 7$ (see Moir 1987).

\section{LN303, Well Site}

This site was described by Corbin et al. (1994:58-59) as a house site of unknown age on an upland ridge (354 feet amsl) above a small intermittent tributary that flows east and north into Boggy Creek. A section of an old road bed (4lLN333) was described as running across the southern part of the small (20 $\mathrm{m}$ in diameter) site. Noted at the site during the initial survey investigations were a stacked rock foundation ( $2 \mathrm{x}$ $1 \mathrm{~m}$ in size) for a fireplace and a well depression about $13 \mathrm{~m}$ to the southeast (Corbin et al. 1994:Figure 13); a portion of an iron wagon wheel was also noted about $20 \mathrm{~m}$ away, in the vicinity of the rock foundation. Only one shovel test was excavated at that time at $4 \mathrm{lLN} 303$, and no artifacts were recovered from it.

The probable remains of a rock chimney foundation and a well were noted on the upland ridge at the Well site when the site was reinvestigated in 2010 (Figure 12). The chimney seat was marked by a ca, $5 \times 5$ $\mathrm{m}$ mound of soil and tabular sandstone cobbles and boulders next to a modern access road. The unlined well was southeast of the chimney mound a short distance. It is about $4 \mathrm{~m}$ in diameter and has a depth of ca. 1-1.5 m. The site is covered in immature hardwoods, with a thick understory of yaupon holly, huckleberry, and mustang grapes, along with bull nettles; surface visibility ranges from $10 \%$ to $20 \%$.

The distribution of cultural features, as well as shovel tests $(n=10)$, indicate that the Well site covers ca. $1800 \mathrm{~m}$ (ca. 0.44 acres) (see Figure 12). Three shovel tests and Unit 303 contain ca. 1890s to early twentiethcentury historical artifacts in archaeological deposits in Padina loamy fine sand sediments that are a maximum of $50 \mathrm{~cm}$ in thickness. In Unit 303 , the highest densities occur at $10-20 \mathrm{~cm}$ bs. One shovel test and Unit 303 also have prehistoric lithic debris of an unknown age.

In the shovel tests, the density of historical artifacts is 1.33 per positive shovel test, or 10.6 artifacts per $\mathrm{m}^{2}$. In the $50 \times 50 \mathrm{~cm}$ unit, the density of historical artifacts is a much more substantial 56 per $\mathrm{m}^{2}$. Artifacts from the site include both domestic and architectural categories. Among the former are one plain ironstone rim sherd (ST 667), amber (1916-1930), clear, and aqua-colored bottle glass sherds, and a clear glass sherd from a medicinal container (ST 667). The architectural items include wire nails (post-1891, $\mathrm{n}=8$ ), cut nails $(1820-1891, n=5)$, and unidentified nail shanks $(n=1)$. The proportion of cut nails $(38 \%)$ in the assemblage points to an occupation that took place beginning about 1893 (cf. Adams 2002).

The prehistoric artifacts from the Well site include a piece of lithic debris from 40-60 cm bs in ST 670 and $10-20 \mathrm{~cm}$ bs in Unit 303. One is a light yellowish-gray chert non-cortical flake and the other is a noncortical flake of red chert. Chipped stone tool knapping or sharpening activities took place at the site, but not in a concentrated manner.

\section{$41 L N 304$}

This presumably historical site, on the crest of an upland landform (390 feet amsl) overlooking the Boggy Creek floodplain, was marked when first recorded in 1992 by a $3 \mathrm{~m}$ diameter oval depression (about $60 \mathrm{~cm}$ 
FIGURE 12. REDACTED

Figure 12. Map of the Well site (41 LN303). 
in depth), and an adjacent mound of clay sediments, that may have represent the attempted excavation of a well (Corbin et al. 1994:85). No artifacts were noted on the surface, and none were recovered in the two excavated shovel tests reported by Corbin et al. (1994).

This site was marked by several surface features when it was relocated during the 2010 archaeological investigations. These include several depressions with berms of soil or an area of fill dirt in Area $A$ and B (Figure 13). The largest of the depressions, at the southern part of the site, is $2.4 \mathrm{~m}$ in diameter and 0.6 $\mathrm{m}$ in depth, with a $1.2 \mathrm{~m}$ red clay berm around it; the berm stands $0.45 \mathrm{~m}$ in height. The function of these depressions is unknown, and it is by no means certain that they are historical cultural features, such as a well.

FIGURE 13. REDACTED

Figure 13. Map of 41 LN304. 
The site area has an overstory of hardwoods, with an understory of huckleberry bushes and green brier; surface visibility is less than $10 \%$. The site, based on shovel testing $(n=10)$ and the distribution of the depressions, covers an area of ca. $1000 \mathrm{~m}^{2}$ (0.25 acres).

No historical artifacts were observed on the surface at 4 lLN304 in the 2010 work, and none were recovered during either the shovel testing or $50 \times 50 \mathrm{~cm}$ unit excavation. It is extremely doubtful that it was occupied during historical times, and the depressions most likely represents nothing more than natural features, perhaps tree tips. This site, however, does have prehistoric archaeological deposits, of an unknown age, with a low density of lithic artifacts from two shovel tests (see Figure 13). These include three pieces of lithic debris: brown chert ( $n=2,50 \%$ cortical) and gray chert ( $n=1$, non-cortical). These are from $0-80 \mathrm{~cm}$ bs in Hearne fine sandy loam sediments. The density of the prehistoric artifacts is 1.0 per positive shovel test (ca. 8 artifacts per $\mathrm{m}^{2}$ ) and a very low 4.0 per $\mathrm{m}^{2}$ in the $50 \times 50 \mathrm{~cm}$ unit.

ST 763 at the northern end of $41 \mathrm{LN} 304$ encountered three unmodified sandstone rocks $(621.4 \mathrm{~g})$, ranging from $12 \times 6 \mathrm{~cm}$ in size, at a depth of $54 \mathrm{~cm}$ bs in the west wall of the shovel test. Such rocks may be part of a prehistoric rock feature, even though unmodified, given their context in relatively thick and nonrocky sandy sediments, but without further investigations, the function of the rocks is unknown.

\section{$41 \mathrm{LN} 305$}

Corbin et al. (1994:60) identified this historical (early twentieth-century) house site on a northwest-facing upland slope (315 feet amsl), about $1.6 \mathrm{~km}$ from Boggy Creek to the north. An old road bed (41LN334) led up to and apparently ended at the site. Noted on the surface at that time was a large brick fireplace foundation ( $4 \times 2 \mathrm{~m}$ on length and width and an estimated $1.6 \mathrm{~m}$ in height), along with a scatter of local and imported TEXAS and MEXIA bricks (ca. 1915-1925), ferruginous sandstone rocks for possible foundation piers, pre-1920s Ford car parts, a Garrett's snuff bottle, and an enameled tin-ware vessel sherd (Corbin et al. 1994:60). Other artifacts reported from the site included plain whiteware sherds, bottle glass sherds, and wire nails ( $n=5$, post-1891, see Wells 2000) (Corbin et al. 1994:Table 8). Two negative shovel tests were excavated at the site. The site covered an estimated $30 \mathrm{~m}$ in diameter.

41 LN305 was relocated along the edge of an upland slope that has an overstory of hardwoods, yaupon holly, and huckleberry bushes; an old road cut bisected the site (Figure 14). The western part of the site has large eroded areas and gullies with sparse ground cover and scattered trees; surface visibility at the site s a whole ranged from $20 \%$ to $30 \%$.

There is one prominent historical cultural feature at the site, a sandstone and brick chimney seat or foundation, along with an associated chimney fall mound and a low mound of sandstone rocks that may be part of the piers to a farmstead structure (see Figure 14). There are also two trash dump areas of surface artifacts just north of the old road cut. The easternmost dump has body parts from a Ford Model A truck, a No. 2 wash tub, buckets, and brick fragments, while the western dump has discarded structure building materials, including roofing sheet metal, CORSICANA BRICK CO., MEXIA (1915-1925), and TEXAS brick fragments, and rusted metal. Based on the shovel testing $(n=14)$, the visible features, and the two dumps, 4 lLN305 covers ca. $2800 \mathrm{~m} 2$ ( 0.7 acres).

During the 2010 archaeological investigations at the site, four shovel tests and Unit 305 recovered early twentieth-century historical artifacts at $0-40 \mathrm{~cm}$ bs in Rader fine sandy loam sediments (see Figure 14). The 
FIGURE 14. REDACTED

Figure 14. Map of $41 \mathrm{LN} 305$. 
density of artifacts in the shovel tests is 4.25 per positive shovel test, or 34.0 artifacts per $\mathrm{m} 2$. The density of artifacts in Unit 305 is 32.0 artifacts per $\mathrm{m} 2$.

The artifacts represent both domestic use at this farmstead, as well as the construction of a wood framed structure after 1891. The domestic artifacts are represented by clear bottle glass sherds $(n=8)$ and aqua-colored bottle glass sherds $(n=2)$; a zinc fruit jar lid and a white milk glass fruit jar lid liner; plain whiteware body sherds $(n=2)$; and plain porcelain body sherds $(n=2)$. The architectural artifacts include wire nails ( $n=6$, post-1891) and two unidentified nail shanks. The absence of cut nails in the artifact assemblage suggests that the site was occupied after ca. 1904 (cf. Adams 2002).

For indications of the age of the occupation other than the wire nails, the fruit jar lid and lid liner provide helpful information. Zinc lid liners, along with the milk glass lid liner inserts, were used up until about 1940 for fruit jars (Brantley 1975).

\section{$41 L N 306$}

41 LN306 was described by Corbin et al. (1994:60-61) as an early twentieth-century house site (ca. $80 \mathrm{~m}$ in diameter) on a northwest-facing upland slope (345 feet amsl); an old road bed (41LN334) ran past the site. There were two rock foundations recorded on the site, along with a $4 \mathrm{~m}$ diameter well depression ( $20 \mathrm{~m}$ west of the house area). The first rock foundation was a $12 \times 7 \mathrm{~m}$ house foundation with rock piers and a rock fireplace $(4.0 \times 2.5 \mathrm{~m})$ at the western end of the house foundation (Corbin et al. 1994:Figure 14). The second rectangular rock foundation ( $10 \times 5 \mathrm{~m}$ in size) may be the remnant a barn about $45 \mathrm{~m}$ west from the house foundation.

Six shovel tests were excavated at $41 \mathrm{LN} 306$ at the time of the initial survey, but it is not clear if any of them contained historical artifacts (Corbin et al. 1994:61). Artifacts that were noted (on the surface?) included MEXIA brick (ca. 1915-1925), an iron wagon wheel, a iron spur, plain whiteware sherds, a handpainted whiteware sherd, a stoneware sherd, and bottle glass (Corbin et al. 1994:Table 8). The size of the site was estimated at $4000 \mathrm{~m}^{2}$ ( 1 acre).

This site was relocated in an area of abandoned primitive campsites and a park road/trail on an upland slope (320-330 ft. amsl) (Figure 15). The area had once been cleared, an had scattered oak trees, but the site has become overgrown with tall weeds and a thick understory of yaupon holly; surface visibility outside of the park road is less than $10 \%$. A single pear tree remains of the several fruit trees that were present during the 1992 Corbin et al. (1994) survey. There are historical artifacts visible in the road/trail, where surface visibility is better (10-20\%), including three plain porcelain and ironstone sherds and one piece of bottle glass (see below).

Based on shovel testing and the surface distribution of artifacts, $41 \mathrm{LN} 306$ covers a ca. $4800 \mathrm{~m}$ area (1.2 acres). The cultural features visible on the site include a sandstone rock pile from a collapsed chimney and scattered sandstone rocks to the north and east of the chimney that may represent rock piers to a structure; the chimney mound stands $50 \mathrm{~cm}$ in height, and is ca. $3.2 \times 1.8 \mathrm{~m}$ in length and width. A $4 \mathrm{~m}$ diameter depression to the west of the collapsed chimney probably represents an old well.

During the 2010 work, six shovel tests and Unit 306 contained historical archaeological deposits (see Figure 15). These deposits were encountered at a depth ranged of $0-40 \mathrm{~cm}$ bs in shovel tests in Hearne fine sandy loam sediments, but at only $0-10 \mathrm{~cm}$ bs in Unit 306, suggesting the site has been eroded in some 
FIGURE 15. REDACTED

Figure 15. Map of 41 LN306. 
areas. The density of artifacts in the shovel testing is 3.5 per positive shovel test or 28.0 artifacts per $\mathrm{m}^{2}$. In Unit 306, the historical artifact density is 144.0 per $\mathrm{m}^{2}$. As previously mentioned, several artifacts were also noted on the surface of the old road bed, including two plain porcelain rim sherds, a plain ironstone body sherd, and an amber-colored (1916-1930) bottle sherd.

The historical artifacts represent both domestic and architectural activities at $41 \mathrm{LN} 306$. The domestic artifacts include refined earthenware sherds, stoneware sherds, several colors of bottle glass sherds, and brown snuff glass sherds ( $n=4$, Figure 16). Among the refined earthenwares are plain whiteware rim, body, and base sherds $(n=7)$, decalcomania whiteware sherds $(n=1$, ca. 1880-1920 and later, see Majewski and O'Brien [1987:147]), red hand-painted whiteware sherds ( $=1$, Figure 17), plain porcelain rim and body sherds $(n=3)$, and plain ironstone body sherds $(n=1)$. Stoneware sherds in the assemblage include Bristolglazed $(n=1)$ and brown lead-glazed $(n=1)$ wares. These would have been manufactured from ca. 1870 to the early twentieth century.

Other domestic artifacts include glass bottle containers, as well as the previously mentioned brown snuff glass. The bottle glass sherds are clear ( $n=8$, including one with embossing), brown ( $n=10)$, purple $(n=5,1880-1915)$, aqua $(n=1)$, and amber $(n=1,1916-1930)$. There is also a milk glass decorative piece from Unit 306.

Among the architectural artifacts are aqua-colored window glass sherds ( $\mathrm{n}=$ 6 , mean thickness $=2.19 \mathrm{~mm}$, estimated manufacture date based on Moir [1987] is $1897.1 \pm 7$, wire nails $(n=2)$, unidentified nail shanks $(n=1)$. These indicate that a wood-framed structure with windows had been built at $41 \mathrm{LN} 306 \mathrm{ca} .1900$.

Other metal in the artifact assemblage includes five pieces from an unidentified cast iron object with a hole for attachment (Unit 306), and a thin iron strap (ST 144, 0-20 cm bs). Lastly, there is an iron fence staple from Unit 306.

\section{$41 L N 307$}

This late nineteenth to early twentiethcentury house site was found on the crest of an upland ridge (340 feet amsl), a short distance south of an old road bed (41LN334) (Corbin et al. 1994:62). It was estimated to cover a $40 \mathrm{~m}$ diameter area of the landform.

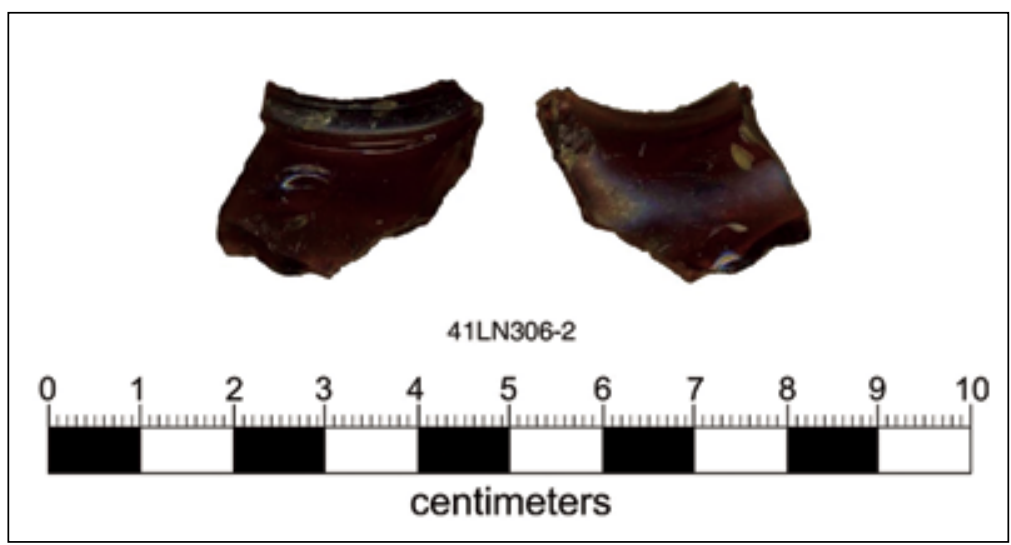

Figure 16. Brown snuff glass sherd.

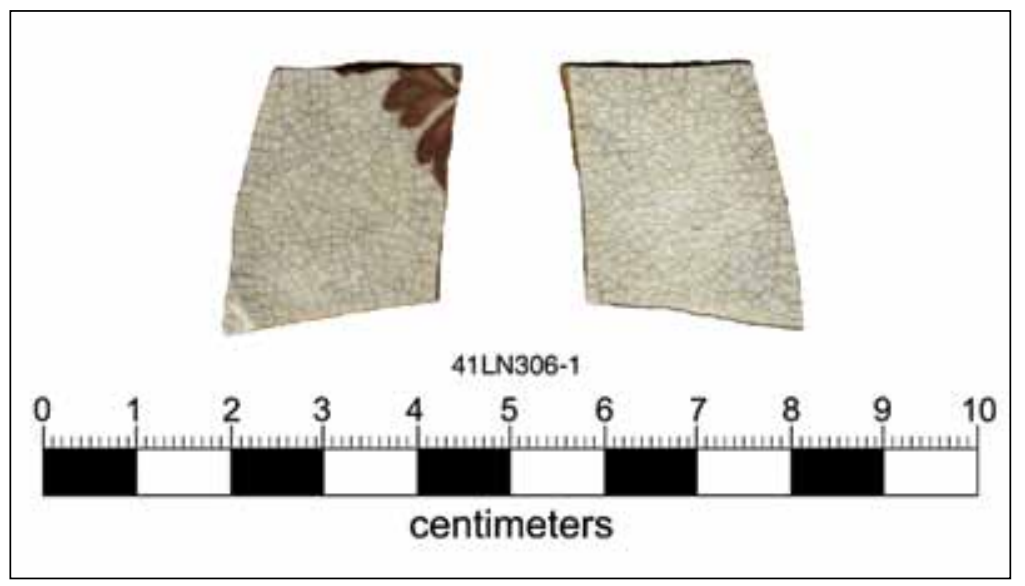

Figure 17. Red hand-painted whiteware body sherd from 41LN306. 
Features identified at $41 \mathrm{LN} 307$ at the time the site was first recorded included a raised house mound platform (2.5 x $2.5 \mathrm{~m}$ in size), stone rubble from a fireplace foundation, two well depressions (ca. $1.5 \mathrm{~m}$ in diameter and 30-40 cm deep) north and east of the house locale, and an associated artifact scatter; a trash dump was also noted in a nearby gully (Corbin et al. 1994:60). No artifacts were recovered from the two shovel tests excavated at the site at that time, but a variety of historical artifacts were noted on the surface and in the dump. These included green transfer-printed sherds, plain whiteware sherds, late nineteenth-century to early twentieth-century decalcomania and repousse sherds (cf. Majewski and O'Brien 1987), stoneware (of an unspecified kind), hand-blown bottle glass lips (Corbin et al. 1994:Figure 37c), CORSICANA brick, cut nails, slate, a piece of lead, a lamp burner base, and a glass flask (Corbin et al. 1994:62 and Table 8).

$41 \mathrm{LN} 307$ was relocated in an old upland clearing, bisected by an old road cut, that has become overgrown with high grass (Figure 18); the overstory is scattered hardwood trees; surface visibility is less than $10 \%$. There are a number of eroded gullies along the margins of the upland ridge, one used for trash dumping. Shovel tests $(n=11)$, historical features, and the distribution of surface artifacts, indicate that the site covers a $1750 \mathrm{~m}^{2}$ area (0.43 acres).

The principal historical cultural feature on the site is a $10 \times 10 \mathrm{~m}$ raised house mound $(30-40 \mathrm{~cm}$ in height) platform. To its south is an irregular $1 \times 1 \mathrm{~m}$ pile of sandstone rocks; their function is unknown, but perhaps the pile represents part of a chimney fall or remnants of a chimney foundation. A small and shallow midden deposit was detected in ST 136 (see Figure 18), perhaps in a yard context, and along the old road between ST 136 and ST 137. Of the wells reported by Corbin et al. (1994), only one possible old well (ca. $3 \mathrm{~m}$ in diameter, but very shallow) was identified near the northeast end of the raised house mound platform; the other could not be detected and may have been destroyed or buried by a modern pipeline and road.

A ca. $10 \mathrm{~m}$ and $4 \mathrm{~m}$ deep gully along the eastern boundary of the site was used as a trash dump (see Figure 18). The dump area had window glass; window screen and wood frames with window screen attached; rusted oil cans; galvanized metal; chicken wire; barbed wire; hog wire; ceramic sewer tubing; a barrel hoop; processed meat cans; and marble fragments. Much of this trash dump material postdates the farmstead occupation.

Three shovel tests and Unit 307 in the 2010 work had historical archaeological deposits (see Figure 18). These deposits in Hearne fine sandy loam sediments occurred in a range of $0-20 \mathrm{~cm}$ bs. The density of artifacts in the shovel tests is 11.0 per positive shovel test or 88.0 artifacts per $\mathrm{m}^{2}$. In Unit 307 , the artifact density is a very high 320.0 per $\mathrm{m}^{2}$.

Most of the historical artifacts at 4 lLN307 are domestic and architectural items. Domestic artifacts include refined earthenware sherds, bottle glass, brown snuff glass $(n=2)$, as well as aquamarine fruit jar glass sherds with a beaded lip $(n=1)$ and milk glass lid liners $(n=4)$. The refined earthenware sherds are plain whiteware body sherds $(n=6)$, decalcomania whiteware $(n=1,1880-1920$ or later), embossed whiteware (dots, $n=1$, see Majewski and O'Brien 1987:Figure 4e), and plain ironstone body sherds $(n=2)$.

The bottle glass sherds are various colors: brown $(n=15)$, clear $(n=20)$, purple $(n=11,1880-1915)$, amber $(n=1,1916-1930)$, blue $(n=1)$, red $(n=1)$, aquamarine $(n=1$, with K3 embossed on the base), and aqua ( $n=15$ ). Milk glass lid liner inserts were used up until about 1940 for fruit jars (Brantley 1975). The one glass fruit jar has a continuous screw thread finish, and is likely from a Mason's Patent closure jar, first 
FIGURE 18. REDACTED

Figure 18. Map of 41LN307. 
patented in 1858, and made up to ca. 1915 (Society for Historical Archaeology 2010), or an early to midtwentieth-century Ball Perfect Mason jar.

Other ceramic artifacts include a six-sided ceramic disk in Unit 307, and a possible ceramic insulator sherd from ST 138. This ceramic disk may be a gaming piece, as have been found in other Texas sites (see Perttula and Nelson 2003:Figure 11). There is also a scalloped white milk glass rim sherd that may be from a decorative piece that was found on the surface.

Artifacts belonging to the architectural group include wire nails $(n=10)$, cut nails $(n=2)$, unidentified nail shanks $(n=6)$, hand-made brick fragments $(n=2)$, and aqua-colored window glass $(n=10)$. Aquacolored window glass was also present in the gully trash dump (see Figure 18). The proportion of cut nails $(16.7 \%)$ suggests that the wood-framed structure built on the site was constructed around 1897 (see Adams 2002). The window glass sherds from Unit 307 has a mean thickness of $1.98 \mathrm{~mm}$, suggesting they are from panes manufactured in $1879.5 \pm 7$; those in the gully trash dump are thicker $(2.35 \mathrm{~mm})$, with a manufacture date of $1910.6 \pm 7$, suggesting two periods of window glass installation at the farmstead structure.

One cast iron piece with a bolt hole was recovered in ST $138(0-18 \mathrm{~cm}$ bs).

\section{LN309, Cedar House Site}

41 LN309 was described as an historical farmstead by Corbin et al. (1994:62) that was adjacent to two old road beds (4lLN331 and 4lLN332) that crossed an alluvial terrace landform (310 feet amsl) north of Boggy Creek. Artifacts noted on the surface (Corbin et al. 1994:64 and Table 8) suggested that the site (estimated at $60 \mathrm{~m}$ in diameter, 0.9 acres) may have been occupied from as early as the mid-nineteenth century (transfer printed whiteware and cut nails) to as late as the early twentieth century (MEXIA bricks, ca. 19151925 and 1933 USDA aerial photographs). Other artifacts on the surface included stoneware sherds ( $n=$ 7 ), bottle glass sherds $(n=2)$, and farm equipment $(n=3)$. Four shovel tests excavated at $41 \mathrm{LN} 309$ did not contain any historical artifacts.

Identified features at the site at that time included two $3 \mathrm{~m}$ in diameter well depressions, and a rock and brick fireplace foundation ( $2.5 \times 3 \mathrm{~m}$ in size) associated with a $6 \mathrm{~m}$ diameter scatter of rocks and bricks around it. MEXIA bricks were in the fireplace rubble. About $4 \mathrm{~m}$ north of the fireplace foundation was a $4 \mathrm{~m}$ lone line of rocks that may be piers from a structure (Corbin et al. 1994:Figure 15). An outbuilding may be marked by several large rocks $50 \mathrm{~m}$ northwest of the $41 \mathrm{LN} 331$ road bed.

When it was relocated in 2010, part of the Cedar House site was in an old clearing now grown up in grasses, while the northern part of the site has an overstory of hardwoods; surface visibility is less than $10 \%$. There are several trees in the northern part of the site that were likely deliberately planted during the time of the historical occupation, including a very large cedar tree about $3 \mathrm{~m}$ in diameter, several large crepe myrtles, and a bois d'arc tree (Figure 19). A road bisects the western half of the site.

The main historical cultural feature visible at the Cedar House site is a sandstone and brick mound, ca. $7 \times 3.4 \mathrm{~m}$ in length and width, that may be the remnants of a chimney foundation. There is a $6 \mathrm{~m}$ line of sandstone rocks to the immediate northeast that may represent the same foundation piers identified by Corbin et al. (1994), and there are midden deposits are present just to the south of this feature in ST 438 (see Figure 19). There are also two shallow $(30-40 \mathrm{~cm})$ depressions north and east of the chimney/structure area, and these may be an abandoned well and a privy hole. Fifteen shovel tests excavated at the site, along with 
FIGURE 19. REDACTED

Figure 19. Map of the Cedar House site (41LN309). 
visible cultural features, indicate that it is $6000 \mathrm{~m}^{2}$ in area ( 1.5 acres), about $65 \%$ larger than estimated by Corbin et al. (1994).

In the course of the 2010 archaeological investigations at Fort Boggy State Park, seven shovel tests and Unit 309 contained historical archaeological deposits in Marques very fine sandy loam sediments at the Cedar House site (see Figure 19). These deposits ranged from $0 \mathrm{~cm}$ bs to $40 \mathrm{~cm}$ bs. ST 438 had very dark grayish-brown to dark grayish-brown midden deposits that ranged from $0 \mathrm{~cm}$ bs to $25 \mathrm{~cm}$ bs. One shovel test (ST 443) and Unit 309 also had prehistoric archaeological materials between $0 \mathrm{~cm}$ bs and $30 \mathrm{~cm}$ bs (Table 7). The density of historical artifacts is 12.9 per positive shovel test or 103.2 artifacts per $\mathrm{m}^{2}$. In Unit 309 , the artifact density is 32.0 artifacts per $\mathrm{m}^{2}$. The prehistoric artifact density is much lower at the site, namely 1.0 per positive shovel test or 8.0 artifacts per $\mathrm{m}^{2}$; in Unit 309 , the prehistoric artifact density is only 4.0 per $\mathrm{m}^{2}$.

Table 7. Distribution of historical artifacts at the Cedar House site (41 LN309)

\begin{tabular}{lcccccccc}
\hline Provenience & Ceramics & $\begin{array}{c}\text { Bottle } \\
\text { Glass }\end{array}$ & Milu Glass & Nails & Brick & $\begin{array}{c}\text { Window } \\
\text { Glass }\end{array}$ & $\begin{array}{c}\text { Metal } \\
\text { Animal } \\
\text { Bone }\end{array}$ \\
\hline Surface & 1 & 1 & 1 & - & - & - & - & - \\
ST 435 & - & 6 & - & 3 & 1 & - & 1 & - \\
ST 438 & 1 & 6 & - & 22 & - & 5 & 4 & 2 \\
ST 439 & - & 1 & - & - & - & - & - & - \\
ST 442 & 1 & 1 & - & 3 & - & - & 3 & - \\
ST 443 & 1 & 1 & - & - & 1 & - & - & - \\
ST 444 & 5 & 13 & - & 2 & 1 & - & 1 & 2 \\
ST 445 & - & - & - & - & - & - & 1 & - \\
Unit 309 & 4 & 1 & - & 2 & - & - & - & 1 \\
\hline
\end{tabular}

The historical artifacts from the Cedar House site are dominated by bottle glass and nails (see Table 7), and the assemblage itself is composed of domestic, personal, and architectural items from a farmstead occupation, along with a few pieces of animal bone.

The historical ceramics on the site include plain ( $n=7$, including one with a bluish tint that may actually be a piece of pearlware found on the site's surface) and decorated ( $n=5)$ whiteware rim and body sherds, as well as one sherd of ca. 1870-1900 brown lead-glazed stoneware. One decorated sherd (Unit 309) has part of an unidentified black transfer maker's mark: "EA...," while another from the unit has a pre-1860s red hand-painted floral design. A third decorated sherd from Unit 309 has a post-1837 Royal Arm's black transfer-printed maker's mark (see Godden 1964:552). This is a compact icon symbol (a quartered shield) with part of a ribbon below it. The best match to this maker's mark from the Cedar House site is the Royal Arm's mark of C. and W. K. Harvey (1835-1853, see Godden 1964:314). Other possibilities include Henry Meakin (1873-1876) or Morley \& Ashworth (1859-1862) (Godden 1964:426, 429). A decorated whiteware sherd from ST 442 is from a pre-1860s blue annular ware. In ST 444, a green floral transfer-printed body sherd was found at 0-20 cm bs (Figure 20). According to Samford (2000:Table 5), the production range 
for green transfer-printed pottery was between 1818 and 1859, with mean beginning and ending production dates of 1830-1846.

Among the bottle glass sherds from the Cedar House site are the following colors: olive green ( $n=1$, pre-1880), aqua $(n=5)$, clear $(n=9)$, brown $(n=11)$, purple ( $n=3,1880-1915$, including one sherd in ST 444 from a decorative platter). Fruit jars were in use at the site, based on the recovery of a milk glass lid liner from the surface. These lids would have been in use throughout the late nineteenth and early twentieth centuries (Brantley 1975). There are also tin can fragments (ST 435).

The final domestic artifact in the sire's

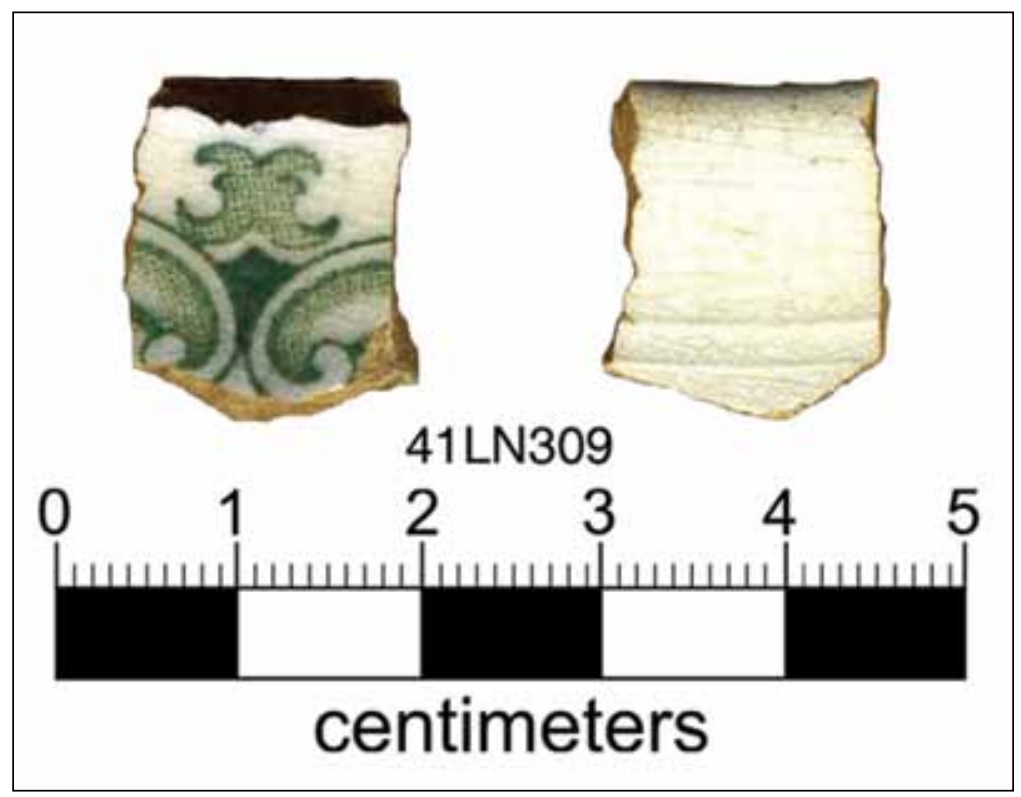

Figure 20. Green transfer-printed sherd from the Cedar House site (41LN309). assemblage is pieces of cast iron kettles $(n=2)$. These are from ST 444 and ST 445 (see Figure 19).

The personal items in the assemblage include a clay marble fragment (ST 444) and a piece of slate. Clay marbles were popular in the United States between ca. 1840 and 1920 (Zapata 1997:108). There are also thin unidentified cuprous fragments that may be from personal items $(n=3)$.

There are also several metal iron tools in the assemblage. These include an iron blade with a hook (ST 442), an iron knife blade fragment (ST 438), and an unidentified piece of iron with a handle (ST 438). Lastly, there are iron fence staples in the assemblage $(n=1)$.

Artifacts that represent architectural activities at the site include machine-made and hand-made brick fragments, some with glazed surfaces $(n=3)$, wire nails $(n=19)$, cut nails $(n=5)$, unidentified nail shanks ( $=8)$, and aqua-colored window glass $(n=5)$. The proportion of cut nails in the assemblage $(20.8 \%)$ suggests that house construction activities at the Cedar House site took place primarily after 1897 (see Adams 2002). The mean thickness of the window glass, on the other hand, at $1.81 \mathrm{~mm}$, suggests that the panes of glass were manufactured in 1865.1 \pm 7 (see Moir 1987). These contrary findings may point to two periods of architectural activity at the site, the first marked by cut nails (1820-1891) and the thin window glass, and the second marked by post-1891 wire nails.

The prehistoric artifacts from the Cedar House site are two pieces of non-cortical lithic debris. They are on petrified wood and dark brown chert raw materials.

\section{LN311, Brick Site}

This historical site was identified as a late nineteenth-early twentieth-century brick kiln (Corbin et al. 1994:64) adjacent to an old road bed (4lLN331) that crosses the large alluvial terrace landform (310 feet amsl) north of Boggy Creek. The principal feature on the site (estimated to cover a $40 \mathrm{~m}$ diameter area) was an $8 \times 8 \mathrm{~m}$ brick rubble platform ( $0.3 \mathrm{~m}$ in height; this may be the brick kiln itself) with dark brown salt 
glazed and orange bricks near the center and outside edges of the platform, respectively. There were also noted two square depressions ( $4 \times 4 \mathrm{~m}$ in size) about $28 \mathrm{~m}$ east of the brick platform/kiln, which may be "slurry/mud pits for mixing mud for bricks" (Corbin et al. 1994:64).

Two shovel tests excavated at that time the site did not contain any historical artifacts. A 1 x $1 \mathrm{~m}$ unit was then excavated in one of the square depressions. The excavations in this unit encountered a large metal plate that may be a door to the brick kiln (Corbin et al. 1994:65), but apparently no other artifacts (Corbin et al. 1994:Table 8).

When the Brick site was relocated during the 2010 work along the eastern edge of the alluvial terrace, the brick kiln platform and the two possible associated depressions where clay may have been obtained were readily apparent on the landform (Figure 21); scattered bricks were also noted on the surface. The site area itself has large oak trees with a thick understory of yaupon holly bushes and mustang grapevines; surface visibility was less than $10 \%$.

The brick platform and likely kiln area covers an $8 \times 8 \mathrm{~m}$ area and stands 50-60 cm in height. The platform is now soil-covered, but there are stacked burials apparent immediately under the surface, along with glazed bricks and fired sediments. The two depressions or uniform-sized pits to the southeast of the brick platform are $10 \times 5 \mathrm{~m}$ in size and about $1 \mathrm{~m}$ deep (see Figure 21). It is not known if they were areas mined for clay to make bricks, or slurry pits, although the latter seems more likely given their size, shape, and depth. The site is estimated to cover a $40 \times 45 \mathrm{~m}$ area ( 0.44 acres).

Two different kinds of hand-made brick fragments $(n=34)$ were the only historical artifacts recovered from $41 \mathrm{LN} 311$ in the 2010 investigations. These were recovered in two shovel tests and Unit 311 at 0-30 cm bs in the brick platform/kiln (see Figure 21). The density of brick fragments is 10.5 per positive shovel test or 84.0 per $\mathrm{m}^{2}$. In Unit 311 , the density is 52.0 brick fragments per $\mathrm{m}^{2}$. The first kind of brick (Type $\mathrm{A}, \mathrm{n}=$ $24)$ is a red color, and several retain a vitrified glaze on one surface. Type $B$ bricks $(n=10)$ have a reddishbrown color, with visible manganese blooms; several also have a vitrified glaze on one surface.

\section{$41 L N 313$}

Site 4 lLN313 was recorded as an early twentieth-century house site (visible on 1936 USDA aerial photographs) situated on an upland slope (310 feet amsl) along the east side of a small intermittent tributary to Boggy Creek, and near an old road bed (4lLN330) (Corbin et al. 1994:65). About $40 \times 20 \mathrm{~m}$ in size (0.2 acres), the principal feature noted on the site was a $1.8 \times 1.5 \mathrm{~m}$ ferruginous sandstone rock fireplace foundation. East of the fireplace was a small scatter of brick (DENTON CORSICANA) and metal fragments (including a leather strap with a metal buckle and what was described on the site form as a metal fireplace roof cover). A single shovel test excavated at $41 \mathrm{LN} 313$ did not contain any historical artifacts.

This site was relocated in 2010 through shovel testing of the upland landform upon which Corbin et al. (1994) reported it to have been situated. The sandstone chimney was marked by an oval pile of rocks about $2.2 \times 1.8 \mathrm{~m}$ in size, along with both hand-made and machine-made bricks (Figure 22). The oval rock pile is ca. $40 \mathrm{~cm}$ in height. There is a metal smokestack north of the chimney, suggesting the direction of chimney fall; bricks are scattered south of the chimney. The site has an overstory of hardwoods, with a thick understory of yaupon holly bushes and mustang grapevines; surface visibility is less than 10\%. To the southeast a short distance is 4 lLN375, a corral marked by a hog wire fence corner, three No. 2 wash tubs, and an enamel bucket or pail (Figure 22). 
FIGURE 21. REDACTED

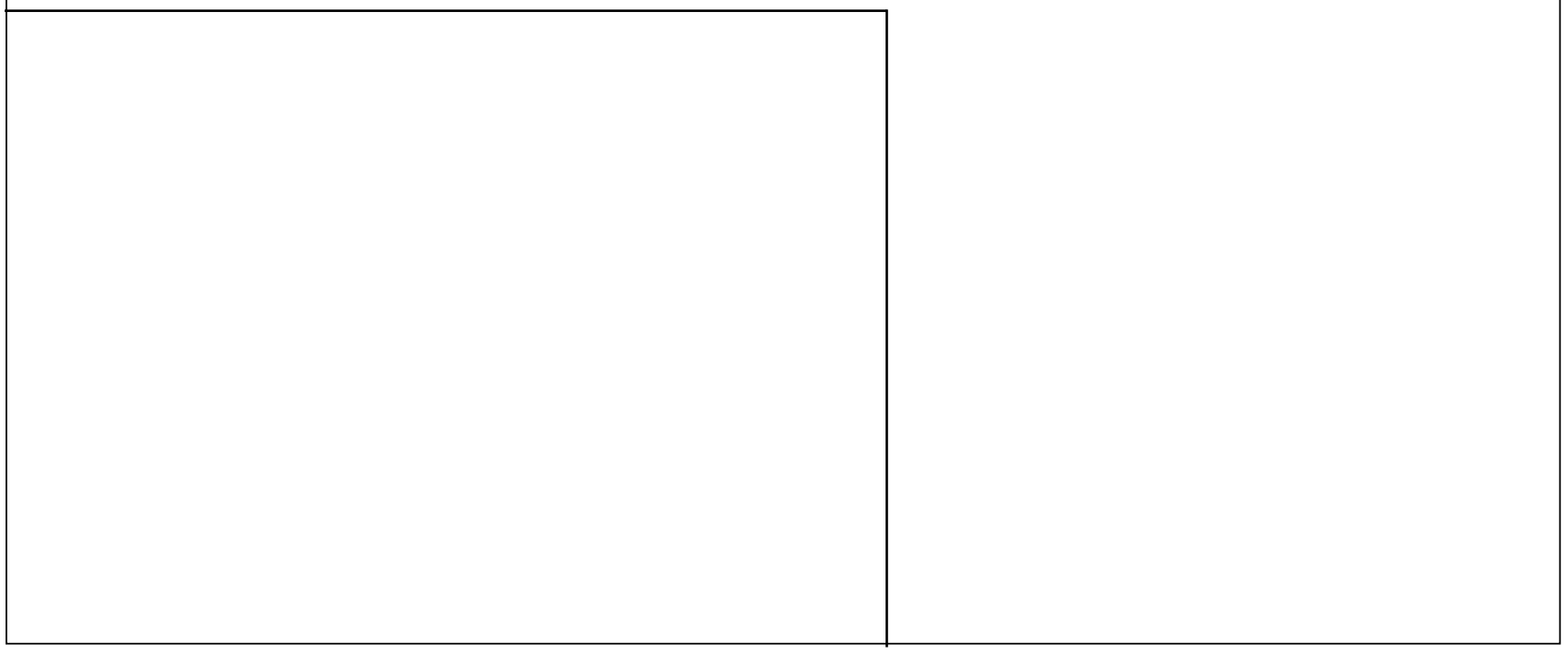

Figure 21. Map of the Brick site. 
FIGURE 22. REDACTED

Figure 22. Map of $41 \mathrm{LN} 313$. 
The site covers a $1050 \mathrm{~m}^{2}$ area $(0.28$ acres), as determined by shovel tests $(\mathrm{n}=16)$, cultural features, and the surface distribution of artifacts, primarily bricks and sandstone rocks. The historical artifacts $(\mathrm{n}=$ 24) recovered from $41 \mathrm{LN} 313$ during the 2010 investigations include a range of domestic and architectural items from five shovel tests and Unit 313 (see Figure 22). They include: wire nails ( $n=7$, post-1891), wire (n $=1$ ), barbed wire $(n=1)$, an unidentified $80 \mathrm{~mm}$ in diameter circular piece of iron (perhaps from a piece of farm equipment), clear and aqua-colored bottle glass $(n=4)$, fruit jar glass $(n=2)$, aqua-colored window glass $(n=5)$, plain whiteware sherds $(n=2)$, and a green circular bead $(8.0 \mathrm{~mm}$ in diameter) from Unit 313. The wire nails are indicative of a post-1890s occupation, as is the bright blue bottle glass (Society for Historical Archaeology 2010). Supporting this age determination is the mean thickness of the window glass $(2.18 \mathrm{~mm}$ ), which is consistent with a production date of $1896.3 \pm 7$ (see Moir 1987, 1988).

These historical artifacts occur from depths of 0-40 cm bs in Wolfpen loamy fine sand sediments. A single ceramic door knob was noted on the surface adjacent to ST 163 (see Figure 22). The density of artifacts in the shovel testing is 2.0 per positive shovel test, or ca. 16 artifacts per $\mathrm{m}^{2}$. In Unit 313 , the artifact density is a more robust 56 per $\mathrm{m}^{2}$.

\section{$41 L N 314$}

This historical site was also recorded as an early twentieth-century house site, about $20 \mathrm{~m}$ in diameter in size, by Corbin et al. (1994:66). It was located on an upland ridge (350 feet amsl) in the northeastern part of the Park. A low mound of ferruginous sandstone rocks that was visible at $41 \mathrm{LN} 314$ marked a fireplace foundation for a farm house. Metal artifacts occurred in scatters around the fireplace and $25 \mathrm{~m}$ to the northeast; both included plow parts, a wagon wheel axle, barrel hoops, and pieces from a large kettle. The one shovel test excavated at the site did not contain any historical artifacts (Corbin et al. 1994:66).

41 LN314 was relocated in 2010 on that upland ridge landform, west of two old road cuts (Figure 23). A barbed wire fence ran across the northern part of the site, with a few metal artifacts (cast iron pot and barrel hoops) to the north of the fence in this area probably associated with $41 \mathrm{LN} 381$, a corral recorded by Corbin et al. (1994), about $35 \mathrm{~m}$ north of the structural features documented during our work as well as Corbin et al.'s (1994) investigations. The site has an overstory of oak, black walnut, and pine trees, with an understory of yaupon holly, mustang grapevines, grasses, and bull nettles; surface visibility was less than $10 \%$.

Two historical cultural features were noted at the site, both mounds of soil ( $1 \times 2$ and $1 \times 3 \mathrm{~m}$ in size) with sandstone rocks and hand-made brick fragments, in the southern part of the site (Figure 23). These may be the bulldozed piles of an old chimney and associated structure piers. The distribution of these features and the results of the shovel testing $(n=18)$ suggest that $41 \mathrm{LN} 314$ covers $2150 \mathrm{~m}(0.5$ acres $)$, much larger than was noted during the initial site recording effort (see above).

In the 2010 investigations at $41 \mathrm{LN} 314$, seven shovel tests and Unit 314 (see Figure 23) had historical artifacts at 0-90 cm bs in Pickton loamy fine sand sediments. The great depth of the historical artifacts suggests there has been considerable artifact movement from fairly recent bioturbation in the deposits. Unit $314(20-30 \mathrm{~cm}$ bs) also had a single prehistoric artifact, of unknown age, a cortical heat-treated quartzite piece of lithic debris. The density of historical artifacts is 2.14 in the positive shovel tests or 17.1 per $\mathrm{m}^{2}$. In Unit 314 , the density of historical artifacts is 12.0 per $\mathrm{m}^{2}$.

The historical artifacts from 4 lLN314 include both domestic and architectural items from a farmstead 


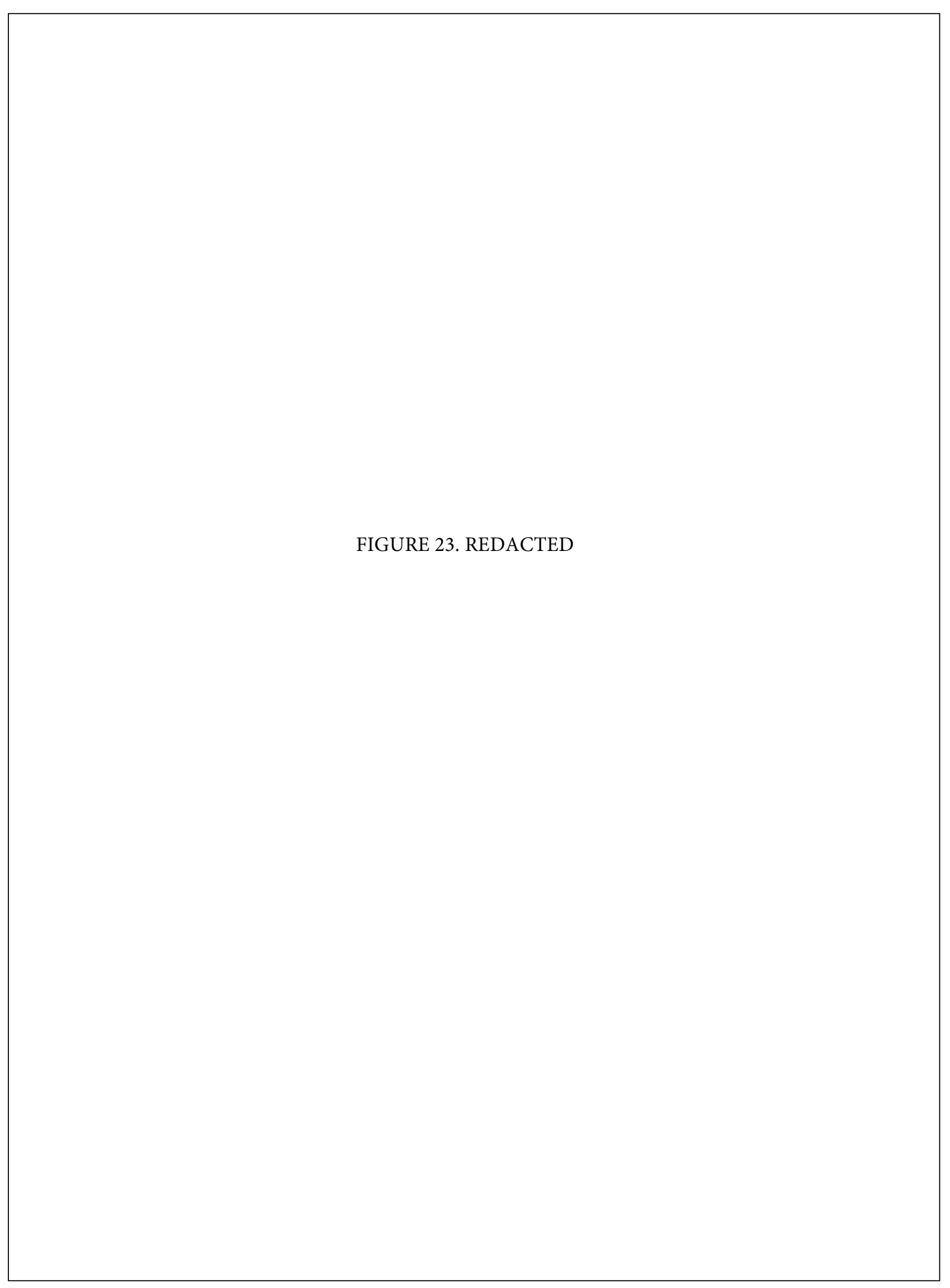

Figure 23. Map of 41 LN314. 
occupation that appears to have been occupied from the late nineteenth to the early twentieth century. The domestic artifacts include plain whiteware rim and body sherds $(n=4)$, clear bottle glass sherds (n $=6$, including one from a very thin medicinal container), purple bottle glass ( $n=1,1880-1915)$, brown bottle glass $(n=1)$, aqua-colored bottle glass sherds $(n=1)$, green bottle glass sherds $(n=1)$, and a purple tableware glass sherd. The architectural remains from the site are represented by aqua-colored window glass (2.10 mm thick, $1889.6 \pm 7$, see Moir 1987), cut nails $(n=1)$, and wire nails $(n=1)$. One of the clear bottle sherds (ST $273,20-40 \mathrm{~cm}$ bs) has letters from an unidentifiable embossed label:

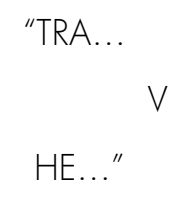

\section{$41 L N 315$}

Like the aforementioned $41 \mathrm{LN} 304$ in this section, this site may represent nothing more than the attempted excavation of an historical twentieth-century well (Corbin et al. 1994:86). The attempted well, on an upland slope (330 feet amsl) as described by Corbin et al. (1994), was marked by a $25 \mathrm{~cm}$ deep depression with an associated $2.3 \mathrm{~m}$ diameter mound of ferruginous sandstone rock and soil. There was also noted a concentration of metal (tin cans, barrel hoops, and unidentified metal fragments) ca. $50 \mathrm{~m}$ to the northwest of the possible well. The one shovel test excavated at the site at that time did not contain any historical artifacts.

In our 2010 relocation work, the possible well identified by Corbin et al. (1994) at this site may be marked by three large sandstone rocks and cobbles in the area of ST 250 (Figure 24), although no depression was visible. The area has an overstory of hardwoods and a thick understory of yaupon holly and mustang grapevines; surface visibility was less than $10 \%$. About $50 \mathrm{~m}$ to the south-southwest a small scatter of metal cans, a wash tub, and MEXIA brick (ca. 1915-1925) pieces was located on the surface. The location of this historical artifact scatter does not match that of Corbin et al. (1994), who noted that a concentration of metal artifacts were found ca. 50 m northwest of the well; no such concentration of metal northwest of the possible well was identified during our investigations, and they may represent two areas of trash discard at the site. $41 \mathrm{LN} 315$, including the area with the sandstone rock concentration, covers a ca. $50 \times 20 \mathrm{~m}(0.25$ acres) of the upland landform.

The possible well depression was noted at the site during our work, but not the associated mound of rock and soil, although there were several pieces of metal cans and a wash tub at the site's plotted location (see Figure 24). The only artifact recovered at $41 \mathrm{LN} 315$ in the 2010 investigations at Fort Boggy State Park is the handle to an iron spade from Unit $315(0-10 \mathrm{~cm}$ bs in the Wolfpen loamy fine sand sediments). Given the absence of other artifacts across the landform, and the dubious possibilities that a depression recorded by SFASU marks an unexcavated well, it is unlikely that this location is in fact an archaeological site.

\section{LN318, Black Walnut House Site}

41 LN318 was recorded as an early twentieth-century house site that was visible on a 1936 USDA aerial photograph and also is apparent on the Leona 7.5-minute topographic quadrangle as an abandoned structure. The site, estimated by Corbin et al. (1994) to have been $25 \mathrm{~m}$ in diameter in size, was adjacent to 
FIGURE 24. REDACTED

Figure 24. Map of 41 LN315. 
an old road bed (41LN330) and situated on an upland slope (320 feet amsl). A scatter of locally-made bricks and rocks may represent the remnants of both a structure and an associated fireplace foundation (Corbin et al. 1994:66-67). Two shovel tests were excavated at that time at 41LN318, but neither contained any historical artifacts (Corbin et al. 1994:Table 6).

Site 41 LN318 is situated in what used to be a hunting camp on an upland slope landform, but is now the residence for the Texas Parks and Wildlife Department (TPWD) Park Manager, as well as a TPWD maintenance area with a large barn (Figure 25) and a tiled well; there is an older wood barn ( $9 \times 9.5 \mathrm{~m}$ in size) with wood and concrete piers about $20 \mathrm{~m}$ to the north. The roads are paved in this area, and there are

FIGURE 25. REDACTED

Figure 25. Map of the Black Walnut House site. 
multiple underground utilities connecting the modern barns and the ranger's residence. The site area is a mowed lawn and four large black walnut trees; surface visibility is less than $10 \%$.

One area on the eastern part of the Black Walnut House site has possible sandstone pier stones from an historical structure foundation (see Figure 25). Early twentieth-century artifacts were found in four shovel tests and Unit 318 at 0-60 cm bs in Wolfpen loamy fine sand sediments (see Figure 25). These artifacts are from domestic and architectural activities at this farmstead. The estimated site size is $3825^{2} \mathrm{~m}(0.95$ acres $)$.

Artifact density in the shovel tests is 3.0 per positive shovel test, or 24.0 artifacts per $\mathrm{m}^{2}$. ST 240 had the highest artifact among the shovel tests. The artifact density in Unit 318, including the one animal bone found at $40-50 \mathrm{~cm}$ bs, is 92 per $\mathrm{m}^{2}$. These artifacts are concentrated at $0-20 \mathrm{~cm}$ bs.

Artifacts of a domestic and/or personal nature from the 2010 investigations at the Black Walnut House site include ceramic sherds, bottle glass and fruit jar sherds, tin can fragments $(n=2)$, a thin piece of wire, and a cupreous 4 -hole clothing button with embossed lettering. The outside of the button is embossed with:

\section{MILLER \\ DALLAS}

On the inside it is embossed with:

\section{P.S. Co.}

\section{Pat. Applied For}

The ceramic sherds are represented by plain whiteware rim and body sherds $(n=2)$. Bottle glass sherds are from brown $(n=5)$, clear $(n=4)$, bright green $(n=3)$, aqua $(n=1)$, and there is a bright green fruit jar glass sherd from Unit 318. The bright green jar glass may have been made by Owens-Illinois Co. as late as ca. 1940 (Society for Historical Archaeology 2010).

The architecturally-related artifacts at the Black Walnut House site include wire nails $(n=10)$ and aqua-colored window glass. The structure built at the site must have been wood-framed and had glass windows. The absence of cut nails suggests an occupation that began after 1904 (see Adams 2002), and this is generally corroborated by the mean thickness of the window glass $(2.18 \mathrm{~mm})$, pointing to a manufacture date on the window glass of $1896.3 \pm 7$ (see Moir 1987).

\section{$41 L N 319$}

This site was reported by Corbin et al. (1994:67) to be an early twentieth-century house site near an old road bed (4lLN331). It was situated on the large alluvial terrace landform (310 feet amsl) north of Boggy Creek. Present at the site was a $4 \times 2$ m rock fireplace foundation consisting of an $80 \mathrm{~cm}$ high mound of stacked rocks, as well as probable rock piers to a 13-14 m long house structure. A rectangular pattern of rocks (rock piers?) $27 \mathrm{~m}$ north of the rock fireplace possibly marked an outbuilding or barn area about $8 \mathrm{~m}$ in length, and the house structure itself was apparent on an 1936 USDA aerial photograph. With an associated scatter of local brick, ceramics (plain whiteware and stoneware), bottle glass, tin cans, and metal artifacts, site size was estimated at $50 \mathrm{~m}$ in diameter (Corbin et al. 1994:67 and Table 8). One negative shovel test was excavated at $41 \mathrm{LN} 319$. 
This site was relocated during the 2010 work by a combination of pedestrian survey and shovel testing $(n=18)$. Much of the site is situated between two old road cuts (Figure 26) on the northern edge of the alluvial terrace, and it is $120 \mathrm{~m}$ from a tributary to Boggy Creek. It has an overstory of hardwood trees and a thick understory of yaupon holly and mustang grapevines; surface visibility is less than $10 \%$.

FIGURE 26. REDACTED

Figure 26. Map of $41 \mathrm{LN} 319$. 
There are several historical cultural features visible at 4lLN319; they had been previously noted by Corbin et al. (1994). They include a sandstone chimney and associated chimney fall, as well as two areas of sandstone piers for structures. The chimney remains cover a ca. $2.3 \times 1.1 \mathrm{~m}$ area, with $1-4$ courses of rock still standing to a height of 10-60 cm above the modern ground surface. Rocks from the chimney fall extend in all directions (see Figure 26), with the heaviest fall to the north and east of the chimney seat.

The first set of piers are mainly 2-4 m east of the rock chimney, and are likely piers to a house foundation (see Figure 26). The second set of piers is north of the house structure remains, and north of one of the old road cuts. These piers may mark the location of an outbuilding, probably a barn. The distribution of positive shovel tests and cultural features indicate that $41 \mathrm{LN} 319$ is ca. $4750 \mathrm{~m}^{2}$ in size (1.2 acres).

Historical archaeological remains were recovered in 10 shovel tests and Unit 319 (see Figure 26). These artifacts were found at 0-52 cm bs in Marques very fine sandy loam sediments, but the majority of the artifacts are concentrated at $0-20 \mathrm{~cm}$ bs. The density of historical artifacts is 2.67 per positive shovel test or 21.4 artifacts per $\mathrm{m}^{2}$. In Unit 319 , the density is 60.0 per $\mathrm{m}^{2}$. One shovel test (ST 461) had a single piece of prehistoric lithic debris (cortical piece of local petrified wood) at 0-20 cm bs. A portion of a machinemade brown bottle was also noted on the surface of $41 \mathrm{LN} 319$ in the $41 \mathrm{LN} 331$ road cut during the 2010 investigations (see Figure 26).

Both artifacts of domestic and architectural use are in the historical artifact assemblage at 4 lLN319. Artifacts of a domestic nature are plain whiteware rim, body, and base sherds $(n=6)$, a late nineteenth-early twentieth-century embossed whiteware body sherd, a plain ironstone base sherd, an early twentieth-century Bristol glaze stoneware sherd with an interior cobalt glaze (see Greer 1981), brown ( $n=3)$ and pre-1905 clear $(n=4)$ bottle glass sherds, and tin can fragments $(n=5)$. Lastly, six pieces of barbed wire were found in ST 470.

The architectural category includes cut nails $(n=1)$, wire nails $(n=2)$, unidentified nail shanks $(n=3)$, and reddish-brown machine-made brick fragments (ST 464), and aqua-colored window glass. The window glass ( $n=5$ sherds) is anomalously thin $(1.84 \mathrm{~mm}$ ) for a twentieth-century farmstead, as that mean thickness corresponds to a manufacture date of $1867.7 \pm 7$ in Moir's (1987) correlation of thickness and manufacture age. An iron wing nut was recovered in ST 463.

\section{$41 L N 324$}

$41 \mathrm{LN} 324$ was recorded as a historical house site, thought to have been occupied after 1890 to the 1930s, based on the recovery of a wire nail from a shovel test and a 1933 USDA aerial photograph (Corbin et al. 1994:67-68 and Table 8). A section of an old road bed (4lLN334) was $20 \mathrm{~m}$ southwest of the site, which was located on a gentle upland slope (340 feet amsl).

The site had a rectangular arrangement of ferruginous sandstone rocks that may mark the remnants of a structure foundation; its size was not noted by Corbin et al. (1994:68). Ten shovel tests were excavated across the $40 \mathrm{~m}$ in diameter site at the time of initial site recording, and plain whiteware, post- 1890 decalcomania whiteware, stoneware (part of a molded ceramic pipe), brick, and brown bottle glass were collected from an unknown number of the shovel tests. Metal artifacts (metal barrel straps and plow parts were mentioned on the site form) were apparently collected from 41LN324, but they are not included in the artifact inventory (Corbin et al. 1994:Table 8). 
The relocation of $41 \mathrm{LN} 324$ in 2010 was aided by the occurrence and visibility of a mound of sandstone rocks that stood about $70-80 \mathrm{~cm}$ in height adjacent to an old road cut (Figure 27). This mound, approximately $3.65 \times 2.70 \mathrm{~m}$ in length and width, and its associated scatter of rocks, likely represents the chimney seat for a rock chimney and its associated historical structure. There was also a shallow depression to the east of the chimney area, and this may be the remnants of an old privy. There are scattered post oak trees on the upland landform, as well as open areas with grasses; surface visibility is less than $10 \%$.

FIGURE 27. REDACTED

Figure 27. Map of $41 \mathrm{LN} 324$. 
During the 2010 archaeological investigations, six shovel tests and Unit 324 contained historical archaeological deposits (see Figure 27 and Table 8). The estimated site size is $2500 \mathrm{~m}^{2}$, more than $50 \%$ larger than was recorded during the initial site recording effort in 1992 . These deposits ranged from $0 \mathrm{~cm}$ bs to $60 \mathrm{~cm}$ bs in Gasil fine sandy loam sediments. The density of historical artifacts at the site is 9.9 per positive shovel test and 79.2 per m. In Unit 324 , the artifact density is 228.0 per m. Prehistoric artifacts-one piece of heat-treated non-cortical quartzite lithic debris-were found in Unit 324 at $20-30 \mathrm{~cm}$ bs.

Table 8. Distribution of historical artifacts at $41 \mathrm{LN} 324$.

\begin{tabular}{lccccccc}
\hline Provenience & Ceramics & Bottle Glass & Snuff Glass & Nails & $\begin{array}{c}\text { Window } \\
\text { Blass }\end{array}$ & Iron/Lead & N \\
\hline ST 65 & 2 & 1 & - & - & - & 2 & 5 \\
ST 66 & 1 & - & 1 & 2 & - & - & 4 \\
ST 71 & 4 & 19 & - & 1 & - & - & 24 \\
ST 72 & 4 & 6 & - & 9 & 3 & - & 22 \\
ST 73 & - & 3 & - & - & - & - & 3 \\
ST 74 & - & - & - & - & - & 1 & - \\
Unit 324 & $8+$ & 15 & - & 30 & 3 & 1 & 57 \\
\hline
\end{tabular}

As with many of the Fort Boggy State Park historical archaeological sites, the best represented historical artifacts at $41 \mathrm{LN} 324$ are bottle glass sherds and nails (see Table 8). As a group, they are indicative of domestic activities (i.e., the serving and containing of food and liquids) and architectural activities, most particularly the construction of a wood-framed structure with a glass-covered window.

The domestic ceramics at $41 \mathrm{LN} 324$ are represented by refined earthenware sherds, including plain porcelain rim and body sherds $(n=4)$, decorated porcelain rim sherds $(n=1)$, plain ironstone body sherds $(n=2)$, decorated whiteware rim sherds $(n=4)$, and plain whiteware rim, body, and base sherds $(n=7)$. The decorated porcelain and whiteware sherds have floral embossed designs $(n=2)$ on the interior surface (Figure 28, bottom), and Majewski and O'Brien (1987:155) suggest these floral motifs were in common use on refined earthenwares between ca. 1870s and 1905. The other decoration, only present on the whitewares, is a green floral decalcomania (ca. 1880-1920s, or later).

The bottle glass and brown snuff glass are from domestic contexts at $41 \mathrm{LN} 324$. The different colors of bottle glass are aqua $(n=3)$, clear $(n=11)$, brown $(n=11)$, green $(n=1)$, aquamarine $(n=17)$, and purple $(n=1,1880-1915)$. Other glass artifacts in the domestic goods category include a clear tableware glass lip sherd from ST 71.

Architectural items at the site include cut nails $(n=5)$, wire nails $(n=29)$, unidentifiable nail shanks and heads ( $(n=8)$, and aqua-colored window glass $(n=6)$. The proportion of cut nails (only $14.7 \%$ ) in the nail assemblage indicates that the main period of architectural activities at $41 \mathrm{LN} 324$ was ca. 1901 (see Adams 2002). The estimated age of the window glass based on its mean thickness (2.14 mm) is $1892.9 \pm 7$ (see Moir 
1897), corroborating the nail data with respect to the timing of the construction of a wood-framed structure with at least one glass window.

The two possible personal items in the artifact assemblage are the stone ware pipe sherd from Unit $324(20-30 \mathrm{~cm}$ bs) (see Figure 28, top) and the piece of slate from Unit $324(0-10 \mathrm{~cm}$ bs). The stoneware pipe sherd is part of the stem and the lower bowl (see Figure 28, top). It is a brown glazed pipe with a molded and fluted body. The two pieces of lead sprue found in ST 65 (20-40 cm bs) indicate that lead bullets were being made on site for hunting activities.

Two miscellaneous pieces of iron are in the $41 \mathrm{LN} 324$ assemblage. These are an iron bracket or handle from ST 74 (0-20 cm bs), perhaps from a piece of furniture, and a large iron bolt (Unit 324, $30-40 \mathrm{~cm} \mathrm{bs}$ ).

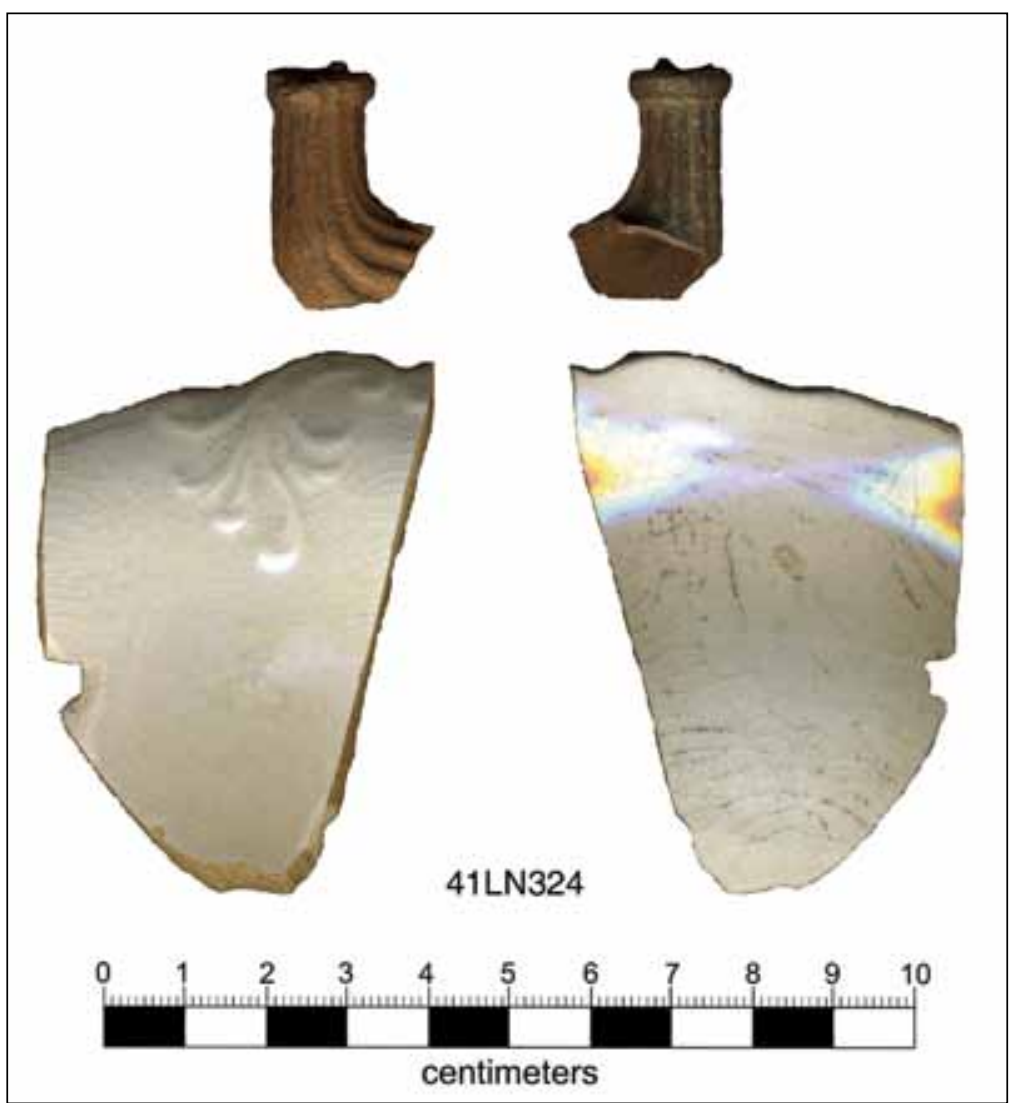

Figure 28. historical artifacts from 41LN324: top, stoneware pipe; bottom, embossed whiteware rim sherd.

\section{$41 L N 337$}

$41 \mathrm{LN} 337$ was reported by Corbin et al. (1994:69) as an early twentieth-century house site (40 m in diameter) by an old road bed (4lLN334) in the southern part of the Park. It was located on an upland slope (360 feet amsl). The house itself, visible on an 1933 USDA aerial photograph, was marked by rock piers; these are still visible today. A single shovel test was excavated at the site by Corbin et al. (1994), but it contained no historical artifacts. There were bottle and flat glass and brick fragments visible on the surface, along with repousse whiteware, and metal fragments (Corbin et al. 1994:Table 8).

In the 2010 site relocation effort at Fort Boggy State Park, 4 lLN337 was marked by a scattered of sandstone rocks that are probably piers to the historical structure that may have stood on the central part of the site (Figure 29). The site has hardwoods over parts of the landform, along with a thick understory of yaupon holly, mustang grapevines, and green brier. In the western part of the site, where there is severe erosion, surface visibility is $50 \%$; elsewhere it is less than $10 \%$.

Twentieth-century artifacts were also recovered from 4 lLN337 during the 2010 archaeological investigations from two shovel tests and the $50 \times 50 \mathrm{~cm}$ unit (see Figure 29). The estimated site size is 2400 $\mathrm{m}^{2}(0.6$ acres). These artifacts were found at $0-20 \mathrm{~cm}$ bs in Rader fine sandy loam sediments. The density of historical artifacts is 2.0 per positive shovel (ca. 16 artifacts per $\mathrm{m}^{2}$ ), and 8.0 artifacts per $\mathrm{m}^{2}$ in Unit 337 . These artifacts include one plain ironstone body sherd and a plain whiteware rim, as well as a ca. 1930s piece of blue Fiesta ware (see Majewski and O'Brien 1987:164), two clear bottle glass sherds-among them 
FIGURE 29. REDACTED

Figure 29. Map of 41 LN337. 
a clear glass base from Owens Bottle Company manufacturers and made between 1903 and 1929 (www. myinsulators.com/glass-factories/bottlemarks2.html, accessed April 13, 2011)_and a tin can fragment.

Several historical artifacts were also noted on the surface at $41 \mathrm{LN} 337$ or near it. These include Model A automobile parts, a No. 2 wash tub, a metal 5 gallon bucket, sewing machine parts, and a gas can (see Figure 29). MEXIA (1915-1925) brick fragments were also present, possibly from a chimney foundation that is not presently visible at the surface.

\section{$41 L N 353$}

This late nineteenth-century to ca. 1930s farm house was reported to have been located on the western side of an upland ridge (350 feet amsl) near an historical road bed (4lLN330). The standing structure, a woodframed (board and batten) building $4.3 \times 4.3 \mathrm{~m}$ in size (and $3.5 \mathrm{~m}$ in height) had a galvanized metal roof, wood flooring, four wood corner piers, and a stone pier supporting the center joist (Corbin et al. 1994:50). It also had at that time a $3 \mathrm{ft}$. door on one side of the building, and one $2 \mathrm{ft}$. window opening. Newspapers lining the interior walls of the building were from an issue (July 8) of the 1904 Leon County Democrat. In 1992, the structure was being used as a barn.

The one shovel test excavated at the site during the SFASU survey did not contain any artifacts, but a cut nail (ca. 1820-1891) and window glass sherds were noted on the surface along the drip line (Corbin et al. 1994:52).

The structure documented in 1992 during the initial survey at Fort Boggy State Park was still standing in 2010, although the structure flooring evidenced increased buckling. It was located on an upland ridge, north of a hog wire fence, and ca. $28 \mathrm{~m}$ west of a cattle feed trough (Figure 30). The landform had an overstory of hardwoods and scattered pine trees, as well as a thick understory of yaupon holly and mustang grapevines. Surface visibility was less than $10 \% 4$

During the 2010 investigations a post-1905 machine-made clear glass bottle was noted by a fence line at the site. It had a screw top, and an embossed base with " 440 WINE." Three of the 10 shovel tests excavated at $41 \mathrm{LN} 353$ and Unit 353 contained historical archaeological deposits at 0-60 cm bs in Wolfpen fine sandy loam (see Figure 30); the majority of the artifacts were found at $0-20 \mathrm{~cm}$ bs, however. Site size is estimated at $1200 \mathrm{~m}^{2}(0.3$ acres $)$. The density of historical artifacts at the site is quite high: 15.3 per positive shovel test or 122.4 per $\mathrm{m}^{2}$, and 292 artifacts per $\mathrm{m}^{2}$ in Unit 353.

The majority of the artifacts from $41 \mathrm{LN} 353$ are clear bottle glass sherds $(n=96)$. Several of these sherds have embossed letters from unidentifiable advertising text on the side of the bottles, including: "...TL," “...ORB...,”“...ART...,”“...E... LE,”"'DS SA...BOTT,” and "W FORB...OF THIS.”

The only other artifacts recovered in the 2010 investigations are wire nails ( $n=15$, post-1891) and cut nails ( $n=1,1820-1891)$; there are also one unidentifiable nail shank (ST 290), and two pieces of iron wire. The low proportion of cut nails (5\%) suggests an occupation that primarily occurred after 1900 (see Adams 2002).

\section{$41 L N 355$}

41 LN355 was reported by Corbin et al. (1994:71) as a house site near two old road beds (41LN331 and $41 \mathrm{LN} 361$ ), on an alluvial terrace landform (320 feet amsl) north of Boggy Creek. The site was marked by a 
FIGURE 30. REDACTED

Figure 30. Map of 41 LN353. 
$50 \mathrm{~cm}$ high stacked rock mound, probably part of a fireplace foundation; site size was estimated at $20 \mathrm{~m}$ in diameter. Only a single shovel test was excavated here at the time of the 1992 survey, and it did not contain any historical artifacts. However, plain whiteware sherds, a brick fragment, bottle glass sherds, and metal farm equipment were collected from the surface of the site (Corbin et al. 1994:Table 8). It is likely that $41 \mathrm{LN} 355$ was occupied from the late nineteenth century to the early twentieth century, like many of the other historical sites at Fort Boggy State Park (see Corbin et al. 1994:52).

The 2010 site relocation effort for 41 LN355 consisted of shovel testing $(n=15)$ across part of an alluvial terrace landform, adjacent and just west of a gas pipeline right-of-way (Figure 31); an old road depression runs just to the north of the site. The overstory on the landform is hardwoods, with an understory of mustang grapevines and yaupon holly. Surface visibility is less than $10 \%$.

The principal historical cultural feature at 4 lLN355 is a circular mound ( $2.5 \times 2.7 \mathrm{~m}$ in length and width) of sandstone rocks and hand-made bricks, probably the foundations to a chimney (see Figure 31); the mound stands $35 \mathrm{~cm}$ in height. During the 2010 work at the site, six positive shovel tests and Unit 355 contained historical archaeological deposits at a range of 0-32 cm bs (see Figure 31) in Silstid loamy fine sand sediments. Site size has been estimated at $2500 \mathrm{~m}^{2}$ (0.6 acres), considerably larger in size than determined during the initial site survey in 1992. The highest densities of artifacts in Unit 355 occurred at $10-30 \mathrm{~cm}$ bs. In the shovel tests, the mean artifact density is 4.3 per positive shovel test, or 34.4 artifacts per

$\mathrm{m}^{2}$; ST 488 had the highest density (ca. 136.0 artifacts per $\mathrm{m}^{2}$ ). The artifact density in Unit 355 is 172.0 per $\mathrm{m}^{2}$. Artifacts noted at the surface at $41 \mathrm{LN} 355$ include metal barrel bands and hand-made brick fragments, all within the sandstone mound/probable buried chimney foundation.

The historical artifacts from $41 \mathrm{LN} 355$ represent domestic, personal, and architectural activities. The domestic artifacts include sherds from ceramic plates (plain porcelain, $n=5$; plain whiteware, $n=2$ ), sherds from bottles (brown, $n=3$; clear, $n=20$; aqua, $n=2$ ), and a cast iron fragment from ST 488. The personal artifacts include a ceramic/milk glass 4-hole button (ST 488). The artifacts that represent architectural activities are wire nails $(n=16$, post-1891), cut nails $(n=4,1820-1891)$, and unidentified nail shanks $(n=$ $5)$. A wood-framed structure had been built on the site. The proportion of cut nails in the assemblage (20\%) suggests that the occupation at the site, or at least the construction of the house structure, may have started ca. 1897 (see Adams 2002).

Two pieces of burned clay/daub are also present in the assemblage (perhaps these are remnants of a mud cat chimney), along with an iron can key, an iron ball and hook, an iron fence staple, a thin piece of wire, a thin piece of hard plastic, and three charred nutshells (Unit 355, 10-20 cm bs).

\section{$41 L N 356$}

This site was recorded as another historical house site on the alluvial terrace (310-320 feet amsl) landform north of Boggy Creek, probably occupied in the late nineteenth to early twentieth century, and situated adjacent to two old road beds (41LN331 and 4lLN361) (Corbin et al. 1994:71). It was marked by a low mound (a chimney seat) of locally-made brick and a surface scatter of bottle glass, brick, and metal fragments over a $20 \mathrm{~m}$ diameter area. One shovel test was excavated at $41 \mathrm{LN} 356$, but it contained no historical artifacts (Corbin et al. 1994:Tables 6 and 8). 
FIGURE 31. REDACTED

Figure 31. Map of $41 \mathrm{LN} 355$.

Site $41 \mathrm{LN} 356$ was readily relocated in the 2010 archaeological investigations because of the intact mound ( $1.6 \times 1.8 \mathrm{~m})$ of sandstone rocks and hand-made bricks adjacent to an old road cut on the alluvial terrace north of Boggy Creek (Figure 32). The mound, which is now only 5-10 cm in height, is likely a chimney foundation or chimney seat. The landform has an overstory of hardwoods and a thick understory of yaupon holly and mustang grapevines. Surface visibility is less than 10\%. 
FIGURE 32. REDACTED

Figure 32. Map of 41 LN356.

Five of the 14 excavated shovel tests at the site, as well as Unit 356, from the 2010 work at $41 \mathrm{LN} 356$ have historical archaeological deposits (see Figure 32). The site covers an estimated $2000 \mathrm{~m}^{2}$ (0.5 acres). The historical archaeological deposits range from $0 \mathrm{~cm}$ bs to $20 \mathrm{~cm}$ bs in Silstid loamy fine sand sediments. The density of artifacts in the shovel tests is 3.2 per positive shovel test and 25.6 artifacts per $\mathrm{m}^{2}$. In Unit 356 , the artifact density is 40 per $\mathrm{m}^{2}$. Artifacts only occurred to $10 \mathrm{~cm}$ bs in Unit 356, however. 
The historical artifacts from the site represent domestic, architectural, and farm activities. The domestic category artifacts include plain whiteware rim, body, and base sherds $(n=6)$, a late nineteenth-early twentieth-century floral embossed whiteware sherd (from ST 498), and bottle glass sherds of different colors (clear, $n=4$; aqua, $n=3$; and brown, $n=1$ ). Architectural artifacts at 41 LN356 are represented by wire nails $(n=5)$ and unidentified nail shanks $(n=3)$. The absence of cut nails in the artifact assemblage suggests that this site was occupied after ca. 1904 (see Adams 2002). The farm activities artifacts include an iron plow part from ST 503 and a piece of iron wire from ST 494. A single piece of animal bone was found in ST 498.

\section{$41 L N 358$}

This likely late nineteenth-early twentieth-century historical site (estimated at $30 \mathrm{~m}$ in diameter in size) was situated in the fork of an old road bed (4lLN333). The site was located on an upland ridge (350 feet amsl) in the southwestern part of the Park.

Present at $41 \mathrm{LN} 358$ were flat rocks that were likely foundation piers from two different buildings of unstated size. In addition to plow parts and a barrel hoop visible on the surface, a cut nail (1820-1891) was recovered from one of the three shovel tests excavated at $41 \mathrm{LN} 358$; the cut nail was not included in the artifact inventory for the site, however (Corbin et al. 1994:72 and Table 8).

Site 41 LN358 was marked by a scatter of sandstone cobbles in the central and southern part of the site, which was on an upland ridge adjacent to an old road cut (Figure 33). The sandstone rocks had no discernible pattern, nor was it evident that they represented foundation piers from two distinct buildings, as Corbin et al. (1994) had suggested. The landform had an overstory of hardwoods with a thick understory of yaupon holly and mustang grapevines. Surface visibility was less than $10 \%$.

Three of the 12 shovel tests excavated across the landform, as well as Unit 358, in the 2010 work contain historical and/or unknown prehistoric artifacts (see Figure 33). Site size is estimated at $20 \times 20 \mathrm{~m}(0.1$ acres). The historical archaeological deposits range from $0 \mathrm{~cm}$ bs to $40 \mathrm{~cm}$ bs in Padina loamy fine sand sediments, while the prehistoric artifacts have been recovered from 60-100 m bs; the deeper occurrence of the prehistoric artifacts suggests the possibility that $41 \mathrm{LN} 358$ contains stratified archaeological remains. The density of historical artifacts is a very low 1.0 per positive shovel test or 8 artifacts per $\mathrm{m}^{2}$. In Unit 358 , the historical artifact density is 4.0 per $\mathrm{m}^{2}$. For the prehistoric artifacts, the density in shovel tests is also low at 1.0 or 8 artifacts per $\mathrm{m}^{2}$; the prehistoric artifact density in Unit 358 is also 4.0 per $\mathrm{m}^{2}$.

The few historical artifacts recovered in the shovel testing and Unit 358 include two plain porcelain body sherds and a clear bottle glass sherd. Additionally, a rim from a ca. 1870-1900 stoneware crock was noted on the surface adjacent to ST 736, outside the defined boundaries of the site (see Figure 33). The sherd has a salt-glazed exterior and a brown lead-glazed interior surface (Figure 34).

The prehistoric artifacts from the site consist of two pieces of lithic debris, one each from ST 742 and Unit 358. They are a petrified wood cortical flake and a non-cortical brown chert hard hammer flake.

\section{$41 L N 365$}

41LN365 was recorded as an early twentieth-century structure, possibly an outbuilding visible on a 1933 USDA aerial photograph (Corbin et al. 1994:72), that was located on an upland ridge (370 feet amsl). The 
FIGURE 33. REDACTED

Figure 33. Map of $41 \mathrm{LN} 358$.

structure location was marked by a level area visible on the ground. An old road bed passes adjacent the small site (ca. $20 \mathrm{~m}$ in diameter in size). Four shovel tests were excavated at the time at the site, but none of them contained historical artifacts. 
The most prominent feature at the site that was noted during the 2010 relocation effort were two large sandstone rocks $(30+\mathrm{cm}$ in length and width) next to each other that may be structure foundation piers. These rocks were ca. $3 \mathrm{~m}$ south of Unit 365 (Figure 35). There were also pieces of angle iron (ca. $70 \mathrm{~cm}$ in length) in the same general vicinity. The site was in an old field, next to an old road cut, with a few large oak trees. The second growth is composed of small hardwoods, yaupon holly, and mustang grapevines.

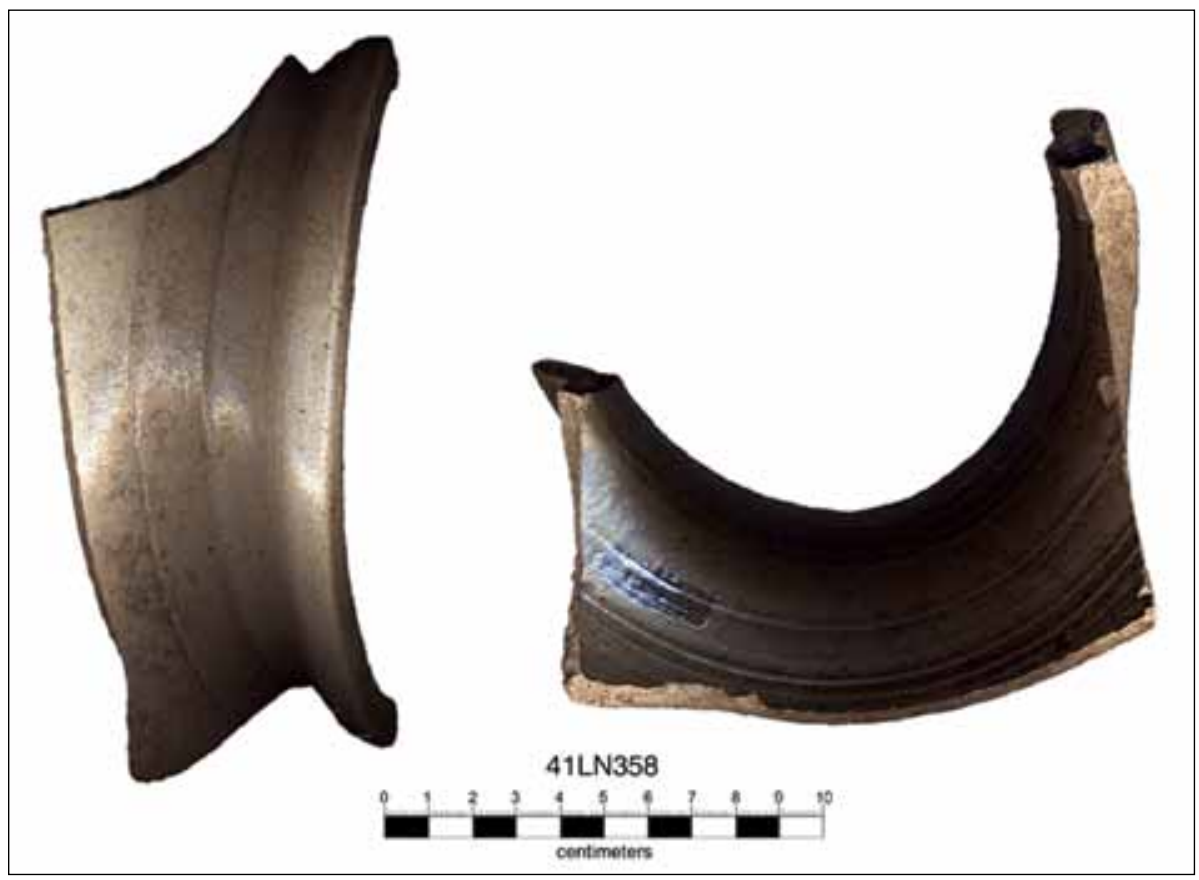

Figure 34. Salt-glazed-lead-glazed stoneware rim from the surface at 41 LN358. Surface visibility is less than $10 \%$.

Only two shovel tests and Unit 365 contain historical archaeological deposits (see Figure 35), delimiting a site area of $20 \times 20 \mathrm{~m}$ in size ( 0.1 acres). These deposits in Padina loamy fine sand sediments range from only 10 to $20 \mathrm{~cm}$ in thickness. The density of historical artifacts is 2.5 per positive shovel test or 20.0 artifacts per $\mathrm{m}^{2}$. In Unit 365 , the historical artifact density is 16.0 per $\mathrm{m}^{2}$.

The artifact assemblage from $41 \mathrm{LN} 365$ is limited to wire nails $(n=6)$, unidentified nail shanks $(n=1)$, and tin can fragments $(n=2)$. Other than evidence of the construction of a wood-framed structure after ca. 1904 as indicated by the wire nails (see Adams 2002), and perhaps by the two large sandstone rocks, as well as the consumption of food stuffs from a tin can, there is little evidence that this site saw much, if any, domestic use. It may indeed mark the location of an early twentieth-century outbuilding.

\section{$41 L N 372$}

1LN372 represented a structure that was visible on a 1933 USDA aerial photograph, although it may not have been occupied on that late of a date (Corbin et al. 1994:75). An old road bed (4lLN373) leads up to the structure location, which was situated on an upland landform (360 feet amsl) in the northeastern corner of the Park. Four negative shovel tests were excavated at the site, but glass and ceramic sherds of unspecified kinds were noted on the surface (Corbin et al. 1994:76).

$41 \mathrm{LN} 372$ was relocated in 2010 through a combination of pedestrian survey and shovel testing $(n=9)$ on an upland landform (Figure 36). The site was marked by a ca. $8 \mathrm{~m}$ diameter circular mounded area (20 $\mathrm{cm}$ in heigh with sandstone rocks and hand-made brick fragments. The mound may represent the remnants of a chimney foundation and chimney fall. Other sandstone rocks encountered in the investigations may be from the collapsed chimney or represent buried pier stones. A second probable historical cultural feature 
FIGURE 35. REDACTED

Figure 35. Map of 41 LN365. 
FIGURE 36. REDACTED

Figure 36. Map of 41 LN372. 
was an oblong depression southwest of the probable chimney area (see Figure 36). The depression was about $1.2 \times 0.6 \mathrm{~m}$ in length and width, and $0.6 \mathrm{~m}$ in depth; this may be a filled-in old well. At the time of the most recent investigations, the site had only a ground cover with grasses and bull nettles (surface visibility was 10-20\%), with hardwoods, pines, and cedar trees surrounding this open area; the latter area also had a thick understory of yaupon holly and mustang grapevines. Surface visibility across parts of the landform was less than $10 \%$.

During the 2010 archaeological investigations at Fort Boggy State Park, three positive shovel tests and Unit 372 contained historical archaeological deposits (see Figure 36). These deposits were 0-60 cm bs in depth in Pickton loamy fine sand sediments, with the majority of the artifacts found from 0-40 cm bs. Unit 372 also had one prehistoric chipped stone artifact (see below). The site size is estimated at $1125 \mathrm{~m}^{2}(0.28$ acres).

The density of historical artifacts at the site, including the animal bone and teeth $(n=15)$, eggshell fragments $(n=11)$, wood charcoal $(n=15)$, is 8.7 per positive shovel test, or 69.6 artifacts per $\mathrm{m}^{2}$. In Unit 372 , the artifact density is considerable, at 284.0 per m². $41 \mathrm{LN} 372$ was the only historical site at Fort Boggy State Park where eggshell fragments were recovered in the archaeological deposits, suggesting there may be a patch of trash midden deposits in the area of Unit 372, the only context where eggshell fragments were recovered at the site.

Both domestic, personal, and architectural categories of artifacts are represented in the assemblage from 4lLN372. The domestic artifacts include refined earthenwares and bottle glass. The refined earthenwares are plain whiteware rim and body sherds $(n=4)$. The bottle glass includes aqua $(n=7$, among them a lip to a medicine bottle), brown ( $n=2$, from a mid-nineteenth-century paneled bottle), and clear $(n=$ 1) glass sherds.

The personal items include a possible cuprous suspender attachment (ST 283, 20-40 cm bs) and a cuprous collar/cuff stud. Mainfort and Davidson (2006:Figure 126b-c) recovered a similar stud in an 1890 context, and patent records indicate this type of stud was patented in 1885 (Mainfort and Davidson 2006:188). A third item, a thin cuprous band with attachment holes, may also represent a fragment of another personal item, even though it is unidentifiable.

The architectural group is represented by cut nails $(n=7)$, unidentified nail shanks $(n=3)$, handmade brick fragments $(n=5)$, and pieces of burned clay/daub $(n=24)$; the latter are possibly remnants of a mud cat chimney on a rock and brick foundation. The absence of wire nails is indicative of an historical occupation that took place sometime prior to 1886 (see Adams 2002). There is also an iron screw from Unit 372 .

The prehistoric chipped stone artifact from $41 \mathrm{LN} 372$ is a perforator or borer made from a brown chert. The working edge of the tool is $6.8 \mathrm{~mm}$ in length.

\section{Historical Sites that were Documented by Photography and Field Observations}

This section of the report discusses the sites that were not shovel tested during the 2010 archaeological investigations at Fort Boggy State Park (see Figure 1). Instead, their current conditions were documented through photography and field observations. 


\section{LN330, DCD Road}

This road bed (estimated by Corbin et al. [1994] as $1200 \mathrm{~m}$ north to south) ran across Fort Boggy State Park (see Figure 1) and has between one and four separate 1.5-4 m deep road cuts and 7-10 m wide, except where it crosses the Boggy Creek floodplain, where it was marked by a 2-4 m wide and 1.5-2 m elevated road bed (Corbin et al. 1994:78-80). The road crossed over Boggy Creek on two bridges, both marked by evidence for bridge pylons. Corbin et al. (1994:78) suggest that this road bed was originally part of an aboriginal trail used prior to ca. 1690, and was the main north-south road for Leon County prior to 1929; its use after 1929 was apparently limited. The road bed passed near a number of historical house sites (4lLN312-314, 4lLN318, 4lLN353, and 41LN372) in the northeastern part of the Park.

Based upon our investigations in 2010, the DCD Road runs for $1580 \mathrm{~m}$ through Fort Boggy State Park, beginning at the Boggy Creek floodplain and runs north. The road cut as we detected it is about $4 \mathrm{~m}$ in width, and up to $3 \mathrm{~m}$ in depth.

\section{$41 L N 331$}

41LN331 was recorded as an east-west historical road bed, $1700 \mathrm{~m}$ in length from east to west, still in active use as late as 1933. The road bed was marked by a 0.5-1.5 m road cut (Corbin et al. 1994:80) that ranged from $4 \mathrm{~m}$ to $80 \mathrm{~m}$ wide, due to multiple road cuts in occasionally impassable areas. Within the Park, this road ran near several house sites on the large alluvial terrace landform north of Boggy Creek, including 4lLN309, 41LN319, 4lLN355, and 4lLN356, as well as an apparent brick kiln site (41LN311).

In our relocation efforts in 2010, the $41 \mathrm{LN} 331$ road bed was determined to run for $1900 \mathrm{~m}$ through the Park, beginning in a floodplain of a tributary to Boggy Creek, then traverses upland landforms to the west and I-45. The road was $4 \mathrm{~m}$ in width, and had road cuts that ranged from very shallow to $1.5 \mathrm{~m}$ bs.

\section{$41 L N 332$}

This historical road bed began at an intersection with $41 \mathrm{LN} 330$, and ran for $1.3 \mathrm{~km}$ across the Park. $41 \mathrm{LN} 309$, a mid-nineteenth to early twentieth-century farmstead on a large Boggy Creek alluvial terrace landform, was just south of the road's beginning point (Corbin et al. 1994:81). The road bed depression was 0.5-1 m deep. Local brick (from the 4 lLN31 1 brick kiln?) was noted at various locations along this old road bed.

Only $833 \mathrm{~m}$ of the $41 \mathrm{LN} 332$ road could be identified as running through the Park in our 2010 relocation effort. It was $4 \mathrm{~m}$ in width, and the road cut a maximum of $1 \mathrm{~m}$ in depth.

\section{$41 L N 333$}

The bed of this historical road, known as the old Leona to Jewett road, cuts across the southwestern part of the Park, but in several sections (Corbin et al. 1994:81-82). The road cut was between 0.5 and $1.5 \mathrm{~m}$ in depth when first documented in 1992. Along its route, it ran near several historical house sites, among them 41LN298-303, and 4lLN358.

The $41 \mathrm{LN} 333$ road, as documented in 2010, traverses upland landforms over a distance of more than $2820 \mathrm{~m}$ in the Park. The old road is $4 \mathrm{~m}$ in width, with a road cut reaching to $1.5 \mathrm{~m}$ bs.

\section{$41 L N 334$}


This old road bed ran across the Park in several sections (totaling ca. $2.5 \mathrm{~km}$, according to the initial site recording effort in 1992), and was marked by a 0.5-2 m road cut (Corbin et al. 1994:83). It ran to or by several historical house sites, including 4lLN305-307, 41LN324, and 41LN337 in the south central part of the Park. One section of the old road had locally-made brick fragments and a broken wagon axle (Corbin et al. 1994:83).

As documented in the 2010 site relocation investigations, the $41 \mathrm{LN} 334$ road bed and its several branches (see Figure 1) traverses more than $3450 \mathrm{~m}$ of upland landforms in the Park. The old road is ca. $4 \mathrm{~m}$ wide, with road cuts up to $1.5 \mathrm{~m}$ in depth.

\section{$41 L N 335$}

This site was recorded by Corbin et al. (1994:83) as a $300 \mathrm{~m}$ long section of an old road bed. It had a 0.5-1 m deep and $3 \mathrm{~m}$ wide road cut. This road was visible on the 1933 USDA aerial photograph.

Based on the 2010 site relocation effort, the 41 LN335 road bed within Fort Boggy State Park, on the east side of I-45, was $276 \mathrm{~m}$ in length, up to $4 \mathrm{~m}$ in width, and $0.5 \mathrm{~m}$ in depth.

\section{$41 L N 336$}

$41 \mathrm{LN} 336$ was recorded by Corbin et al. (1994:69) as a $4560 \mathrm{~m}^{2}$ (1.1 acres) rock quarry of limestone in an area of dissected uplands ( 320 feet amsl) in the southeastern part of the Park that was used in 1933 for building materials on Highway 75. After the limestone was removed, the area was apparently leveled off, and road construction materials were stored on-site. No shovel tests were excavated here at that time, but metal straps and glass sherds (of unknown kind, but mentioned on the site forms as modern in age) were apparently collected from the site (Corbin et al. 1994:69).

In 2010, the area of $41 \mathrm{LN} 336$ was a grasses-covered upland slope (Figure 37), but surface visibility was $30-40 \%$. In addition to wooden planks visible on the surface, there was a pile of modern bricks, culvert pipes, a mason jar, pieces of unidentifiable metal, and glass sherds.

\section{$41 L N 352$}

Corbin et al. (1994:49) described this site as a ca. 1940s "recreation site" on a west facing upland slope (310 feet amsl) in the southeastern corner of the Park, adjacent to a small lake constructed on a northward-facing tributary to Boggy Creek. The site had a brick-lined well, remnants of a wood fishing pier, a corral, a brick barbecue pit, a fishing cabin (an old school bus), a bath house, and a marble picnic table top. The site was estimated to cover 80 meters in diameter (1.6 acres). No shovel tests were excavated during this earlier work, and no artifacts were recovered; the site form noted that glass, cans, brick, and metal artifacts were present at the site.

When the site was relocated in 2010, most of the facilities of the abandoned family camping area (donated to TPWD by the Sullivan family) were noted over a $40 \times 40 \mathrm{~m}$ area of an upland slope, about $50 \mathrm{~m}$ east of a tributary to Boggy Creek, along the eastern shore of an TPWD lake. The landform has an overstory of hardwoods, and surface visibility is less than $10 \%$.

The camping area facilities that remain at $41 \mathrm{LN} 352$ include a picnic table, a brick and mortar well, camp grill, a fire ring, a lantern hanger, a railroad tie, a metal can and brick scatter that may be the remnants 
FIGURE 37. REDACTED

Figure 37. Map of $41 \mathrm{LN} 336$.

of a barbeque pit, and the remains of an old bath house. The fishing cabin/old school bus has been removed since the site was initially recorded, but the school bus door was noted on the surface during the site visit. 


\section{$41 L N 354$}

This site was recorded as an historical boundary line and fence along the northern boundary of Fort Boggy State Park (Corbin et al. 1994:70). This boundary line was traced back to an 1839 land division between tracts owned by J.W. Irwin and James Irwin (Corbin et al. 1994:70). The boundary was marked by a $2700 \mathrm{~m}$ long barbed wire fence, some strands of which were identified as the 'Winner" brand patented in 1874. The boundary line and fence also crossed an old road bed (4lLN331).

In 2010, there are remnants of barbed wire fencing (either embedded in trees, laying along the surface, or buried in the ground) along the $2040 \mathrm{~m}$ that marks the historical property boundary line at Fort Boggy State Park. The 4 lLN354 fence started in the southern part of the Park in the Boggy Creek floodplain, and runs roughly north-south to the northern boundary of the Park (see Figure 1).

\section{$41 L N 359$}

41 LN359 was reported to be a $100 \mathrm{~m}$ long section of an old north-south running road bed that ran by $41 \mathrm{LN} 345$, a multi-component late nineteenth-early twentieth-century house site and prehistoric lithic scatter (Corbin et al. 1994:106-107). It was marked by a $0.5 \mathrm{~m}$ deep road cut (Corbin et al. 1994:84).

In 2010, the road bed remains the same as it was described in Corbin et al. (1994), with a $100 \mathrm{~m}$ section within the boundaries of Fort Boggy State Park. It is approximately $3 \mathrm{~m}$ in width and up to $50 \mathrm{~cm}$ in depth.

\section{$41 L N 360$}

Corbin et al. (1994:84) recorded this site as a $400 \mathrm{~m}$ long section of an old road bed that intersects 4lLN331, another old road bed; it was also visible on a 1933 aerial photograph. The road bed was apparently heavily eroded and had 1-2 m deep road cuts.

Approximately $480 \mathrm{~m}$ of the $41 \mathrm{LN} 360$ road bed are within the western part of Fort Boggy State Park, beginning at I-45 along the park's western boundary. The old road bed is $3-4 \mathrm{~m}$ wide and up to $4 \mathrm{~m}$ deep.

\section{$41 L N 361$}

This site was recorded as a $2.4 \mathrm{~km}$ section of an old north to northeast-running road bed marked by $0.5-2$ $\mathrm{m}$ deep road cuts (Corbin et al. 194:84) and scattered brick fragments; the road eventually ran northeast to Centerville. On its route, it ran by two house sites (4lLN355 and 4lLN356) located on the large alluvial terrace landform north of Boggy Creek.

The old road bed in 2010 is marked by a linear depression that runs for approximately $1.45 \mathrm{~km}$ through Fort Boggy State Park. This old road ranges from $3 \mathrm{~m}$ to $4 \mathrm{~m}$ in depth and has ruts that are up to $2 \mathrm{~m}$ in depth; in several places where the road ran upslope, there are multiple road cuts. The road begins along the western boundary of the Park near I-45, and ran parallel to a small tributary of Boggy Creek, before angling to the northeast and exiting at the northern boundary of the Park (see Figure 1).

\section{$41 L N 362$}

$41 \mathrm{LN} 362$ was reported to be a short section (ca. $0.75 \mathrm{~km}$ ) of old road bed that intersected and ended at another old road (41LN330) (Corbin et al. 1994:85). It passed by 4lLN353, a late nineteenth-century to 1930s 
house site in the northeastern part of the Park, and terminated at the DCD Road (41LN330). The road cut was 0.5-1 $\mathrm{m}$ in depth.

In the 2010 site relocation work, the $41 \mathrm{LN} 362$ road was determined to run within the Park for a distance of approximately $1.08 \mathrm{~km}$. It was ca. $4 \mathrm{~m}$ in width, and had road cuts that ranged from $0 \mathrm{~m}$ to $1 \mathrm{~m}$ in depth. The road itself entered the Park along its eastern boundary, north of 4lLN353, and ran northeast until it exited along the Park's northern boundary (see Figure 1).

\section{$41 L N 366$}

This site was recorded as a corral adjacent to and west of $41 \mathrm{LN} 309$, a mid-nineteenth- to early twentiethcentury farmstead (see above) on the large alluvial terrace landform (310 feet amsl) north of Boggy Creek. An old road bed (4lLN332) ran between the two sites (Corbin et al. 1994:73). The fenced corral was visible as a square soil discoloration on 1933 and 1989 aerial photographs, and metal-detecting noted that nails (of an unspecified kind) were present at this location. No shovel tests were excavated at that time at 41 LN366.

The old corral location was marked in 2010 by a modern $20 \times 20 \mathrm{~m}$ T-post barbed wire enclosure. This modern feature was situated in an overgrown field at the location recorded by Corbin et al. (1994) with a ground cover of tall grasses; surface visibility was less than $10 \%$.

\section{$41 L N 367$}

This historical corral was also near $41 \mathrm{LN} 309$, but located to the south along the southern edge of the alluvial terrace (300 feet amsl) north of Boggy Creek, and another old road bed (41LN331). It was visible on a 1989 color infrared aerial photograph as a soil discoloration (ca. $40 \mathrm{~m}$ in diameter), and metal detecting noted that nails (of an unknown kind) were present there (Corbin et al. 1994:73). One shovel test excavated at the site contained a pre-1890 cut nail and a glass sherd, although the artifact inventory for the archaeological did not include these finds (Corbin et al. 1994:73 and Table 8).

Other than visiting and confirming the location of $41 \mathrm{LN} 367$ in the 2010 relocation effort at Fort Boggy State Park, no further work was conducted here. The area was situated in an overgrown pasture with a ground cover of tall grasses.

\section{$41 \mathrm{LN} 368$}

4lLN368 was reported by Corbin et al. (1994:73-74) to be an old cattle-dipping tank, possibly associated with the $41 \mathrm{LN} 309$ farmstead to the northeast a short distance, that was subsequently used as a trash dump. The dipping tank was $10 \times 2 \mathrm{~m}$ in length and width, and it was apparently lined with metal. A single shovel test was excavated at the site, but it did not contain any historical artifacts. There were locally-made bricks and metal farm equipment visible on the surface (Corbin et al. 1994:74).

In the 2010 relocation effort, we were unable to identify the reported cattle dipping tank at $41 \mathrm{LN} 368$, although there was a $10 \times 4 \mathrm{~m}$ depression (30-40 cm in depth) there that we have interpreted instead as a small section of an old road cut that was later used as a trash dump. This depression (30-40 cm in depth) was $10 \mathrm{~m}$ long and $4 \mathrm{~m}$ wide, and was only $4 \mathrm{~m}$ east of another old road cut (4lLN332); both were the same width. The road cut/dump was in an oak grove in an old overgrown field, with an understory of mustang grapevines; surface visibility was less than $10 \%$. 


\section{$41 L N 369$}

This historical corral was reported to be about $200 \mathrm{~m}$ south of $41 \mathrm{LN} 309$ and an old road bed (4lLN332), located on the large alluvial terrace landform (300 feet amsl) north of Boggy Creek. It was visible on both 1933 aerial and 1989 color infrared aerial photograph as a soil discoloration (ca. $40 \mathrm{~m}$ in diameter), and metal detecting noted that nails (of an unknown kind) were present there (Corbin et al. 1994:73). No shovel tests were excavated at 4 lLN369 during the initial site recording work in 1992.

Other than visiting and confirming the location of $41 \mathrm{LN} 369$ in the 2010 relocation effort at Fort Boggy State Park, no further work was conducted here. The area was situated in an overgrown field with a ground cover of tall grasses and bull nettles. Surface visibility was less than $10 \%$.

\section{$41 L N 370$}

This site was reported by Corbin et al. (1994:74-75) to be an early twentieth-century site on the southern slopes of an alluvial terrace landform (280 feet amsl) overlooking Boggy Creek and the Boggy Creek floodplain, adjacent to an old road bed (4lLN332). A 1933 USDA aerial showed a structure, probably a pole barn, at this location; site size is estimated at $20 \mathrm{~m}$ in diameter. Six shovel tests were excavated at 4 lLN370, but none of them contained any historical artifacts (Corbin et al. 1994:75 and Table 6).

No evidence of the barn at $41 \mathrm{LN} 370$ was obtained during the 2010 site relocation effort at the location identified by Corbin et al. (1994), although shovel tests were excavated in the area as part of the relocation and evaluation of the archaeological deposits at 41 LN321 (see below), specifically about $60 \mathrm{~m}$ south of a nineteenth-century component area at the site. None of those shovel tests recovered any archaeological materials. The area where $41 \mathrm{LN} 370$ was reported has scattered oak trees and a grass ground cover.

\section{$41 L N 371$}

$41 \mathrm{LN} 371$ was recorded as a $390 \mathrm{~m}$ section of a boundary line and barbed wire fence. The fence line was also visible on an 1933 USDA aerial photograph (Corbin et al. 1994:75). No shovel tests were excavated at the site at the time.

In 2010, the boundary line was still occasionally marked by post-1890s barbed wire (Waukegan patented) embedded in several trees, or barbed wire laying on the surface along the old fence line boundary. The $250 \mathrm{~m}$ section ran along one boundary of the T. J. Oden land tract within the Park.

\section{$41 L N 373$}

This short $(250 \mathrm{~m})$ section of old road bed intersected with a larger old road (4lLN330), and ended in a clearing associated with $41 \mathrm{LN} 372$, an early twentieth-century structure in the northeastern corner of the Park. The road cut ranged from $3 \mathrm{~m}$ in width and 0.5-1.5 $\mathrm{m}$ in depth (Corbin et al. 1994:85).

As documented in 2010, during the site relocation effort, $41 \mathrm{LN} 373$ consisted of a $200 \mathrm{~m}$ section of an old road bed in Fort Boggy State Park. The road, which ran along the eastern boundary of the park, and in its northeastern section, was $3 \mathrm{~m}$ in width and $20-60 \mathrm{~cm}$ in depth.

\section{$41 L N 374$}


This site was recorded as a corral visible on an 1933 USDA aerial photograph on $n$ upland toe slope (300 feet amsl), about $30 \mathrm{~m}$ south of $41 \mathrm{LN} 312$, an early twentieth-century house site, and near an old road bed (41LN330) (see Corbin et al. 1994:76). The estimated size of $41 \mathrm{LN} 374$ was $40 \mathrm{~m}$ in diameter. No shovel tests were excavated at the site during the initial site recording effort.

No archaeological evidence of the $41 \mathrm{LN} 374$ corral was recovered during the 2010 site relocation effort, even though the purported location of the corral was extensively shovel tested during the assessment of $41 \mathrm{LN} 310$ (a prehistoric site) and the Halfway House (4lLN312), an historical site dating between the midnineteenth century and ca. 1930; the corral may have been associated with this farmstead. There were two modern (i.e., post-dating 1960) livestock feeders with corrugated sheet metal roofing at the corral location reported by Corbin et al. (1994). There were oak and pine trees in the old corral location as well as open areas with a ground cover of grasses and bull nettles.

\section{$41 L N 375$}

41 LN375 was another early twentieth-century corral detected on a 1933 USDA aerial photograph, and a soil discoloration was also visible on a 1989 color infrared aerial photograph (Corbin et al. 1994:76). The corral, situated on an upland slope (310 feet amsl), was near $41 \mathrm{LN} 313$, an early twentieth-century house site and an old road bed (4lLN330) (see Figure 22). The estimated size of 4 lLN375 was $40 \mathrm{~m}$ in diameter. No shovel tests were excavated at the site when it was first recorded in 1992.

This corral was relocated during the 2010 archaeological survey as a $20 \times 20 \mathrm{~m}$ area marked by a downed hog wire fence (see Figure 22) a short distance east of an historical farmstead at 4lLN313. This area also had four wash tubs and a blue enamel pot visible on the ground surface. The estimated site size is 0.1 acres. It was in an area of hardwoods and a thick understory of yaupon holly and mustang grapevines; surface visibility was less than $10 \%$.

\section{$41 L N 380$}

This site was an early twentieth-century corral detected on a 1933 USDA aerial photograph, and a soil discoloration was also visible on a 1989 color infrared aerial photograph (Corbin et al. 1994:77). The corral, situated on an upland slope (320 feet amsl) was near 41LN318, an early twentieth-century house site, and an old road bed (4lLN330). The estimated size of $41 \mathrm{LN} 380$ was $40 \mathrm{~m}$ in diameter. No shovel tests were excavated at the site during the 1992 site recording work.

The corral at $41 \mathrm{LN} 380$ is marked today by a concrete tiled livestock watering trough at the northern edge of $41 \mathrm{LN} 318$ (see Figure 25), an early twentieth-century farmstead to which the corral was probably associated. The trough appears to have been located in the southwestern corner of the old corral. The trough had underground piping attached to a float that kept the water supply at a constant level; the piping has been disconnected, and only holds rain water at the present time.

\section{$41 L N 381$}

This site was an early twentieth-century corral on an upland ridge (340 feet amsl) detected on a 1933 USDA aerial photograph, and a soil discoloration was also visible on a 1989 color infrared aerial photograph (Corbin et al. 1994:77). The corral was near 4lLN314, an early twentieth-century house site, and an old road 
bed (4lLN330) (see Figure 23). The estimated size of $41 \mathrm{LN} 381$ was $40 \mathrm{~m}$ in diameter. No shovel tests were excavated at the site during the initial site recording work.

In our 2010 archaeological investigations, the remnants of this corral, probably associated with $41 \mathrm{LN} 314$, was marked by a cast iron pot or washtub, rusted bucket fragments, barrel straps, plow points, and a hog wire fence that covered a rectangular $40 \times 20 \mathrm{~m}$ area. There was an associated soil berm that followed the hog wire fencing.

\section{Prehistoric Sites}

\section{$41 L N 308$}

This site was recorded as a prehistoric habitation site of Woodland period age on a large alluvial terrace (300-305 feet amsl) that projected east into the Boggy Creek floodplain; the site was estimated to cover a $300 \times 100 \mathrm{~m}$ area (7.4 acres) (Corbin et al. 1994:88-89 and Figure 22) and had archaeological deposits in sandy sediments more than $1.6 \mathrm{~m}$ in thickness. An old road bed (4lLN331) ran along the northern and western parts of the site.

A total of 80 shovel tests were excavated at $41 \mathrm{LN} 308$ during the initial site recording effort, and 27 of them contained prehistoric artifacts (Corbin et al. 1994:Figure 22). Recovered artifacts included 12 plain sandy paste Goose Creek Plain, var. unspecified (cf. Story 1990) sherds-all from shovel tests at the southern end of the ridge-lithic debris $(n=76$ ), and two petrified wood lithic tools (a scraper and a chopper, see Corbin et al. 1994:Figures 30d and 32).

$41 \mathrm{LN} 308$ is one of the larger and more complex of the prehistoric sites at Fort Boggy State Park. It was relocated in 2010 with extensive shovel testing $(n=52)$ on a relatively narrow part of an alluvial terrace overlooking the Boggy Creek floodplain (Figure 38). The terrace landform is covered in high grasses, yucca, and bull nettles, and there are a few hardwood trees on the site; surface visibility is less than $10 \%$. Old and modern roads cut cross the main portion of the site as well as an area at its northern end.

During the 2010 archaeological investigations at 4 lLN308, a total of 28 shovel tests and Unit 308 had prehistoric archaeological deposits in Padina loamy fine sand sediments (see Figure 38 and Table 9). The estimated size of $41 \mathrm{LN} 308$ is $18,000 \mathrm{~m}^{2}$ (4.5 acres). These archaeological deposits are thickest at the far southeastern part of the site, with depth ranges of 80-100+ $\mathrm{cm}$ bs, with the exception of ST 412 at the far northern end of the site, which also has deposits $100+\mathrm{cm}$ in depth. Across the remainder of $41 \mathrm{LN} 308$, the prehistoric archaeological deposits occurred at only 0-60 cm bs. Prehistoric midden deposits have been identified as a very dark grayish-brown and organically stained loamy fine sand that is about $20 \mathrm{~m}$ in diameter at the southern tip of the landform. The midden ranges from $0 \mathrm{~cm}$ bs to $59 \mathrm{~cm}$ bs in Unit $308,79 \mathrm{~cm}$ thick in ST 363, and $80 \mathrm{~cm}$ thick in ST 403 (see Figure 38).

Three radiocarbon dates have been obtained from single charred hickory nutshells from the midden deposits at $41 \mathrm{LN} 308$ (Table A6.1). OxCal, version 4.1.7 (Bronk Ramsey 2009) and IntCal 09 (Reimer et al. 2009) were used to calibrate the dates and determine the 2 sigma relative area under the probability distribution for each of the three dates. 
FIGURE 38. REDACTED

Figure 38. Map of 41 LN308. 
The two sigma calibrated age ranges of the hickory shell in the midden at $41 \mathrm{LN} 308$ are as early as 1400-1518 B.P. (A.D. 432-550) to as late as 963-1015 B.P. (A.D. 935-987). These calibrated age ranges indicate that much of the midden deposits accumulated during the latter half of the Woodland period, with some use of the midden area in the early part of the Late Prehistoric period.

Including hickory nutshells $(n=26)$, wood charcoal of indeterminate species and not fully carbonized $(n=8)$ (see Appendix 6), and animal bones ( $n=20$, see Appendix 5), the densities of prehistoric artifacts in the shovel tests is 5.6 per positive shovel test, or 44.8 artifacts per $\mathrm{m}^{2}$. In Unit 308 , the artifact density is 176.0 per $\mathrm{m}^{2}$. The highest densities of artifacts in the shovel tests occur in the midden deposits at the southeastern end of the site; this is particularly so for the shovel tests containing burned clay, charred nutshells, and pieces of animal bone (Table 9 and see Figure 38). The most common constituents of the midden deposits are lithic debris, nutshell, and animal bone. The prehistoric ceramic sherds are distributed mainly in the southeastern end of the site, in the Woodland and early Late Prehistoric midden deposits (at 40-60 cm bs), but were also recovered from ST 381 in the south central part of the site as well as ST 409 and ST 411 in the central and northern part of the landform.

There are three chipped stone tools in the $41 \mathrm{LN} 308$ lithic assemblage, including two dart points. The first dart point, from ST 398 (0-20 cm bs) in the far northwestern part of the site (see Figure 38), is a heavily resharpened Early Archaic (ca. 8800-8000 years B.P.) Angostura point (Figure 39a). The blade has been reworked into a bifacial drill, and the blade has been broken laterally. It has a slightly contracting stem and a concave base, no barbs, and light grinding along the stem. The point is made from a yellowish-gray chert, possibly a non-local lithic raw material. The Angostura is $34.0+\mathrm{mm}$ in length, $16.0 \mathrm{~mm}$ in width, $7.9 \mathrm{~mm}$ thick, and it has a stem width of $14.0 \mathrm{~mm}$.

The second dart point is a Woodland period Godley point (see Turner and Hester 1999:125) from ST $411(20-40 \mathrm{~cm} \mathrm{bs})$ in the northern part of the site. The point is made from a local petrified wood, has an expanding stem, a flat base, and small outward-pointed barbs (see Figure 38b). Its measurements are: 41.5 $\mathrm{mm}$ in length; $22.8 \mathrm{~mm}$ in width; $9.2 \mathrm{~mm}$ thick; and the stem width is $12.9 \mathrm{~mm}$.

The last of the chipped stone tools is a bifaciallyworked hafted drill fragment from ST $370(0-20 \mathrm{~cm}$ bs). It is made on a gray chert, and has a $6.5 \mathrm{~mm}$ thick bit.

The one ground stone tool in the assemblage (see Table 9) is a mano fragment (25.0 mm thick) made from a local quartzite cobble. There are grinding areas on both surfaces of the mano.

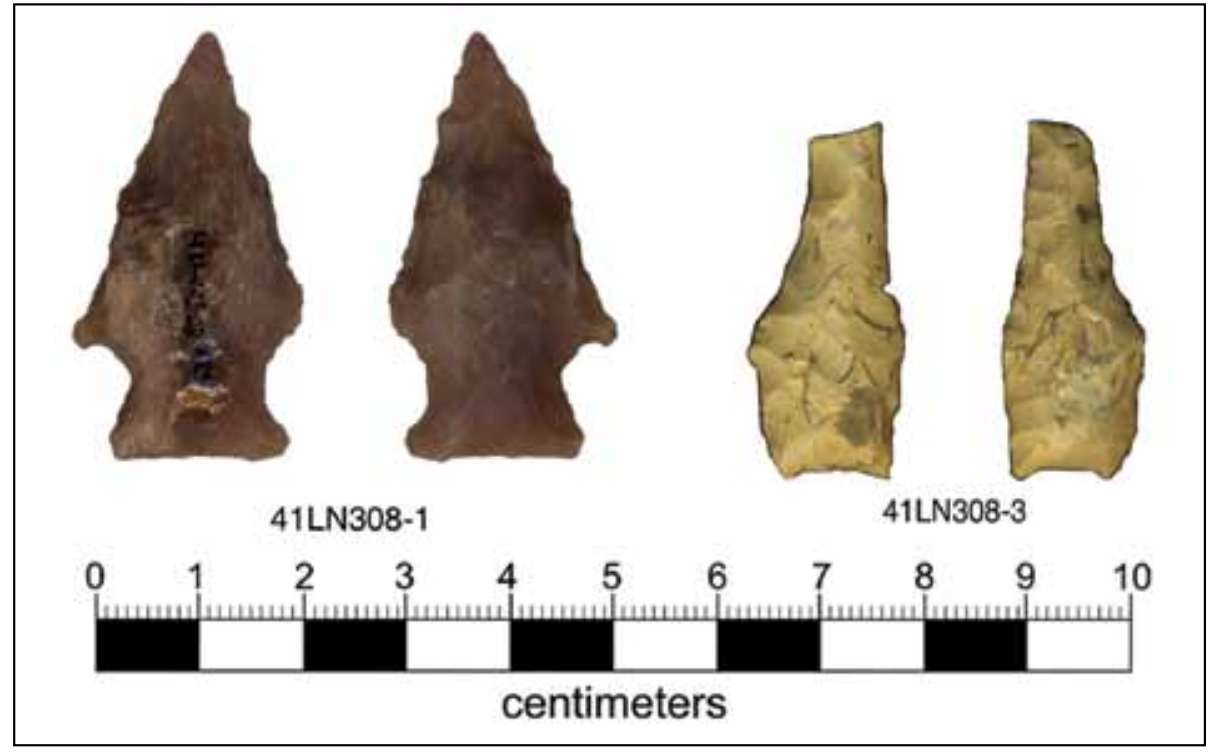

Figure 39. Dart points from 41LN308: a, Angostura; b, Godley. 
Table 9. Distribution of prehistoric artifacts at 41 LN308.

\begin{tabular}{|c|c|c|c|c|c|c|c|c|c|c|}
\hline PROVENIENCE & $\mathrm{DS}$ & PS & $\mathrm{DP}$ & $\mathrm{T}$ & GS & $\mathrm{LD}$ & $\mathrm{BC}$ & NS & WC & $A B$ \\
\hline Surface & - & - & - & - & - & 2 & - & - & - & - \\
\hline ST 363 & 1 & 1 & - & - & - & 6 & 6 & 2 & 1 & 9 \\
\hline ST 364 & - & - & - & - & - & 2 & - & 2 & - & - \\
\hline ST 365 & 1 & - & - & - & - & 4 & - & - & 5 & - \\
\hline ST 367 & - & - & - & - & - & 2 & - & - & - & - \\
\hline ST 368 & - & - & - & - & - & 1 & - & - & - & - \\
\hline ST 370 & - & - & - & 1 & - & 4 & - & - & - & - \\
\hline ST 371 & - & - & - & - & - & 3 & - & - & - & - \\
\hline ST 372 & - & - & - & - & - & 3 & - & - & - & - \\
\hline ST 373 & - & - & - & - & - & 2 & - & - & - & - \\
\hline ST 377 & - & - & - & - & - & 1 & - & - & - & - \\
\hline ST 378 & - & - & - & - & - & 5 & - & - & - & - \\
\hline ST 380 & - & - & - & - & - & 4 & - & - & - & - \\
\hline ST 381 & - & 2 & - & - & - & 1 & - & - & - & - \\
\hline ST 383 & - & - & - & - & - & 2 & - & - & - & - \\
\hline ST 388 & - & - & - & - & - & 7 & - & - & - & - \\
\hline ST 389 & - & - & - & - & - & 2 & - & - & - & - \\
\hline ST 390 & - & - & - & - & - & 3 & - & - & - & - \\
\hline ST 391 & - & - & - & - & - & 2 & - & - & - & - \\
\hline ST 397 & - & - & - & - & - & 1 & - & - & - & - \\
\hline ST 398 & - & - & 1 & - & - & 2 & - & - & - & - \\
\hline ST 403 & - & - & - & - & - & 5 & 1 & 6 & - & 2 \\
\hline ST 404 & - & - & - & - & - & 5 & - & 6 & - & 5 \\
\hline ST 405 & - & - & - & - & - & 3 & - & - & - & - \\
\hline ST 406 & - & - & - & - & - & 3 & - & - & - & - \\
\hline ST 407 & - & - & - & - & 1 & 1 & - & - & - & - \\
\hline ST 409 & 1 & - & - & - & - & - & - & - & - & - \\
\hline ST 410 & - & - & - & - & - & 1 & - & - & - & - \\
\hline ST 411 & - & - & 1 & - & - & 8 & - & - & 4 & - \\
\hline ST 412 & - & - & - & - & - & 1 & - & - & 1 & - \\
\hline Unit 308 & 1 & 2 & - & - & - & 30 & 2 & 10 & 1 & 4 \\
\hline Totals & 4 & 5 & 2 & 1 & 1 & 116 & 9 & 26 & 12 & 20 \\
\hline \multicolumn{11}{|c|}{$\begin{array}{l}\text { DS = decorated sherd; } \mathrm{PS}=\text { plain sherd; } \mathrm{DP}=\text { dart point; } \mathrm{T}=\text { flake tool; } \mathrm{GS}=\text { ground stone tool; } \mathrm{BC}= \\
\text { burned clay; NS = nutshell;WC = wood charcoal; } \mathrm{AB}=\text { animal bone } \\
\text { Does not include fire-cracked rock from ST } 363(\mathrm{n}=1,0.1 \mathrm{~kg}) \text { and ST } 411(\mathrm{n}=1,0.1 \mathrm{~kg})\end{array}$} \\
\hline
\end{tabular}

The lithic debris from 4 lLN308 includes two cores and 114 pieces of lithic debris. The first core (ST 371, $20-40 \mathrm{~cm} \mathrm{bs}$ ) is a multi-platform flake core, with cortical remnants, on a local quartzite (65 mm in length, 73 $\mathrm{mm}$ in width, and $52 \mathrm{~mm}$ thick). The other cores (Unit 308,0-10 cm) is a bipolar core on a cortex-covered reddish-gray chert. It is $20.8 \mathrm{~mm}$ in length, $21.5 \mathrm{~mm}$ in width, and $8.6 \mathrm{~mm}$ thick. The occurrence of a bipolar 
core suggests some knapping activities were designed specifically for the reduction of pebbles for flakes.

The lithic debris itself includes pieces of local quartzite $(n=11 / 5$ cortical debris), petrified wood ( $n=$ $46 / 14)$, and chalcedony ( $n=1 / 0)$, as well as a variety of cherts. The cherts, from a probable mixture of local and non-local (Central Texas) source areas, are represented by red chert $(n=3 / 1)$, reddish-brown chert ( $n$ $=1 / 1)$, brown chert $(n=6 / 4)$, yellowish-brown chert $(n=1 / 0)$, yellowish-gray chert $(n=3 / 1)$, dark brown chert $(n=1 / 0)$, dark brown chert with blue inclusions $(n=1 / 0)$, light gray chert $(n=8 / 0)$, gray chert $(n=$ $14 / 1)$, grayish-brown chert $(n=9 / 1)$, brownish-gray chert $(n=2 / 0)$, dark grayish-brown chert $(n=1 / 0)$, dark gray chert $(n=2 / 0)$, dark gray-black chert $(n=1 / 0)$, white chert $(n=3 / 1$, including one with a roughened limestone cortex). One of the pieces of lithic debris is wedge-shaped. Shafer (2011:99) has identified wedge-shaped flakes from several Early Caddo period contexts in East Texas, and they are distinctive flakes that were "produced by hard-hammer flaking and retain the striking platform (often of cortex) on the proximal end and a wide, feather, edge on the other."

Nine aboriginal ceramic sherds, eight body sherds and one rim, have been recovered in the 2010 work at 4 lLN308 (Table 10). Two of the sherds, from Unit 308 in the midden, are plain sandy paste Goose Creek Plain, var. unspecified body sherds from two different vessels. These are probably from bowls, based on their body wall thickness $(5.1 \pm 0.9 \mathrm{~mm})$; one has a smoothed exterior, while the other has been smoothed only on the interior vessel surface. One of the sherds is from a vessel that was fired and cooled in a low oxygen environment, while the other came from a vessel that was fired and cooled in a high oxygen environment.

Table 10. Aboriginal ceramic sherds from 41LN308.

\begin{tabular}{|c|c|c|c|c|}
\hline Provenience (CM BS) & SHERD TYPE & TEMPER & Paste & DECORATION \\
\hline \multirow[t]{2}{*}{ ST 363, 40-60 } & body & bone & sandy & plain \\
\hline & body & bone & sandy & parallel brushed \\
\hline ST $365,20-40$ & body & grog & sandy & $\begin{array}{l}\text { opposed and cross-hatched } \\
\text { engraved lines }\end{array}$ \\
\hline ST 381, 0-20 & body & bone & clayey-silty & plain \\
\hline ST $381,40-60$ & body & bone & clayey-silty & plain \\
\hline ST 409, 0-20 & body & grog & sandy & $\begin{array}{l}\text { closely-spaced parallel incised } \\
\text { lines }\end{array}$ \\
\hline \multirow[t]{2}{*}{ Unit 308, 40-50 } & body & - & sandy & plain \\
\hline & body & - & sandy & plain \\
\hline Unit $308,50-60$ & rim & grog & clayey-silty & $\begin{array}{l}\text { horizontal and diagonal incised } \\
\text { lines }\end{array}$ \\
\hline
\end{tabular}

The other sandy paste sherds from $41 \mathrm{LN} 308(n=4)$ are from vessels tempered with either grog $(50 \%)$ or bone (50\%). All four of the sherds are from vessels fired in a reducing environment, and only one sherd (the engraved sherd from ST 365, 20-40 cm bs) has been smoothed (interior surface only). The range of vessel wall thickness is $6.7-9.5 \mathrm{~mm}$, suggesting some large vessels were in use at the site, and the mean thickness is $7.6 \pm 0.95 \mathrm{~mm}$. One of these sherds is plain, but the other three are decorated. The first of the decorated sherds is an engraved fragment from a carinated grog-tempered sandy paste bowl (Figure 40a). The design consists of a zone of cross-hatching next to a zone of opposed engraved lines. Similar sherds have been noted from the ca. A.D. 1260-1410 occupation at the McGuire's Garden site (41FT425) at the 
Jewett Mine (Gadus et al. 2002:Figure 50b-d), also in the Post Oak Savannah in the Trinity River basin. The second decorated sherd is a grog-tempered sandy paste jar with closelyspaced parallel incised lines (Figure 40b). It is from a vessel that was fired in a reducing environment, but cooled in the open air (see Teltser 1993:Figure 2f). The third decorated sherd is a parallel brushed jar body sherd. Brushed sherds are present in post-A.D. 1200 Caddo sites in East Texas as well as

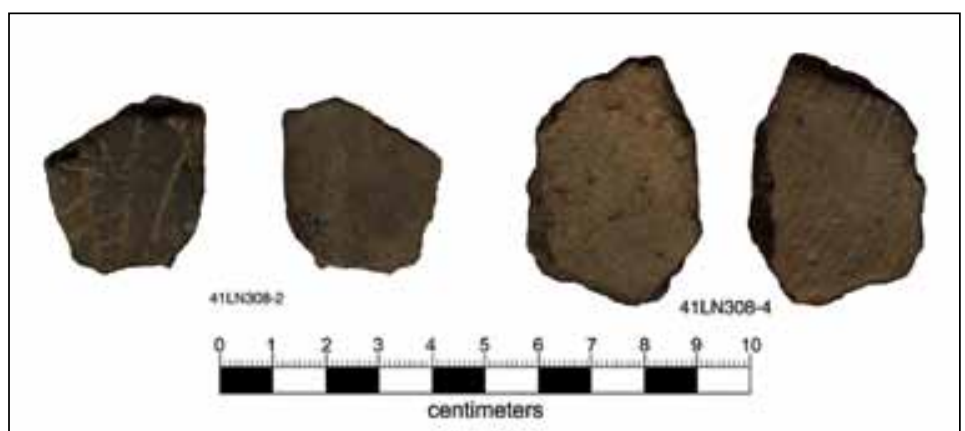

Figure 40. Decorated ceramic sherds from 41LN308: a, engraved; $b$, closely-spaced parallel incised lines. contemporaneous sites in East Central Texas that likely were not occupied by Caddo peoples. Brushed pottery may have been locally made or obtained in trade with a Caddo community.

The last three sherds have a clayey to silty paste and are tempered with either bone or grog (see Table 10). They are from vessels that were fired in a reducing environment, have no surface treatment, and have thin rim $(5.1 \mathrm{~mm}$ ) and body (mean thickness $6.25 \pm 0.5 \mathrm{~mm}$ ) walls. The one decorated sherd (Unit 308, $50-60 \mathrm{~cm} \mathrm{bs}$ ) is a jar rim with a horizontal incised line encircling the vessel, and with at least one diagonal incised line on the rest of the rim; these diagonal lines appear to be widely-spaced on the rim, but no doubt continue around the rim as part of the motif (cf. Dunkin Incised).

Based on the depths of the different temper-paste wares at $41 \mathrm{LN} 308$, it is impossible to differentiate any that are stratigraphically earlier or later, although it is suspected that the Goose Creek Plain, var. unspecified sandy paste sherds represent the earliest, and Woodland age, ceramics at the site. The sandy paste sherds are found at $40-50 \mathrm{~cm}$ bs; the tempered sandy paste wares occur at 0-60 cm bs; and the clayey to silty wares were also recovered at 0-60 $\mathrm{cm}$ bs, all in a distinct midden deposit, as well as in non-midden deposits. It is possible that all three wares represent distinct parts of a single ceramic assemblage, one that likely dates after the thirteenth century A.D. based on the few decorated sherds that are present, although that is unlikely. It is more probable, based in large measure on the three radiocarbon dates from the midden, that the few recovered sherds from temporally distinct ceramic wares have become mixed in the midden deposits by bioturbation.

Lastly, a single plain whiteware body sherd (post-1830s) was noted on the surface at 4 lLN308 in the modern road cut.

\section{LN316, Dogwood Beaver Site}

$41 \mathrm{LN} 316$ was reported to be a small (20 $\mathrm{m}$ in diameter) prehistoric site of unknown age on a south-facing upland ridge and toe slope (320 feet amsl) in the northern part of the Park. Nine shovel tests were excavated here, and they contained two pieces of lithic debris, a core, possible ferruginous sandstone fire-cracked rock, and animal bone that was found at $35-50 \mathrm{~cm}$ bs (Corbin et al. 1994:90 and Table 7). The B-horizon clay was apparently encountered at $75 \mathrm{~cm}$ bs.

A 1997 seismic survey project led to the excavation of at least three additional shovel tests at the Dogwood Beaver site, which contained prehistoric lithic debris at $80-140 \mathrm{~cm}$ bs. The size of the site was expanded to "at least $100 \mathrm{~m}$ in diameter" (Corbin 1997:4). 
In 2010, shovel testing $(n=16)$ on an upland ridge and toe slope (310-320) led to the relocation of the Dogwood Beaver site adjacent to a gas pipeline right-of-way (Figure 41) and along the southern side of the landform. The landform has a hardwood overstory and a thick understory of yaupon holly, mustang grapevines, and green brier; surface visibility was less than $10 \%$.

FIGURE 41. REDACTED

Figure 41. Map of the Dogwood Beaver site. 
Shovel tests indicate that the site covers a ca. $40 \times 15 \mathrm{~m}$ area ( 0.15 acres). A low density of prehistoric lithic artifacts of unknown age was recovered from the Dogwood Beaver site in the 2010 investigations. These artifacts occurred at 0-40 cm bs in Pickton loamy fine sand sediments in two shovel tests and Unit 316 (see Figure 41). A possible charcoal-stained pit feature (Feature 316-1) was identified in Unit 316 at 28-42 $\mathrm{cm}$ bs; it is at least an estimated $60 \mathrm{~cm}$ in diameter at $35 \mathrm{~cm}$ bs; the profile suggests the pit has straight sides and a nearly flat base. The feature fill is a dark gray fine sandy loam with charcoal chunks, flecking, and organic staining. The presence and preservation of the pit features suggests that the Dogwood Beaver site may have been used in prehistoric times for more than simply chipped stone tool manufacture activities.

The density of prehistoric artifacts in the shovel testing is 2.0 per positive shovel test (ca. 16 artifacts per $\mathrm{m}^{2}$ ). That density increases to 32 artifacts per $\mathrm{m}^{2}$ in the $50 \times 50 \mathrm{~cm}$ unit (but only 12 artifacts per $\mathrm{m}^{2}$ if the wood charcoal from the $30-40 \mathrm{~cm}$ bs depth is excluded as possibly unrelated and of more recent age).

The recovered artifacts consist of seven pieces of lithic debris and five pieces of wood charcoal (Unit $316,30-40 \mathrm{~cm}$ bs). The lithic debris includes pieces of petrified wood ( $\mathrm{n}=4 / 25 \%$ cortical), gray chert (a wedge-shaped flake [see Shafer 2011], $n=1)$, brown chert $(n=1)$, and brownish-gray chert $(n=1 / 100 \%$ cortical). The two cortical pieces of lithic debris have smooth surfaces, suggesting they came off pieces of raw material gathered from stream gravels.

\section{LN317, Clear Cut Site}

Corbin et al. (1994:90) recorded this site as a small (20 $\mathrm{m}$ in diameter) scatter of chipped stone lithic artifacts on a westward-facing upland ridge slope (310 feet amsl) above a small intermittent tributary that flows east to Boggy Creek. Fourteen shovel tests were excavated at $41 \mathrm{LN} 317$ at that time, along with apparently two $1 \times 1 \mathrm{~m}$ units in the west central part of the site (mentioned on the site form, but not in Corbin et al. [1994]), and recovered from them from depths of less than $15 \mathrm{~cm}$ bs were four pieces of lithic debris, fire-cracked rock, and a Late Archaic (ca. 4000 years B.P.) Williams dart point (Corbin et al. 1994:Figure 29f).

The Clear Cut site was relocated by shovel testing $(n=18)$ on the upland ridge slope, and adjacent to a road cut (Figure 42). The area had been cleared for pasture in the past, but in recent years, and currently, the landform is covered with small hardwood trees, yaupon holly, american beauty, mustang grapevines, green brier, bull nettles, and grasses; surface visibility outside of the road cut is less than $10 \%$.

Site size is estimated at only $20 \times 20 \mathrm{~m}$ ( 0.1 acres). A low density of prehistoric artifacts were recovered at the Clear Cut site in the 2010 investigations at $10-50 \mathrm{~cm}$ bs in Pickton loamy fine sand sediments. These include a petrified wood core fragment with a smoothed stream-rolled cortex, three pieces of lithic debrispetrified wood ( $n=2,50 \%$ cortical) and a very coarse grayish-white quartzite ( $n=1$, non-cortical)_and two pieces of wood charcoal (possibly of more recent age than the chipped stone artifacts) from two shovel tests and Unit 317 (see Figure 42). The density of prehistoric artifacts at the site is 1.5 per positive shovel test (ca. 12 artifacts per $\mathrm{m}^{2}$ ) and only 4.0 artifacts per $\mathrm{m}^{2}$ in the $50 \times 50 \mathrm{~cm}$ unit (excluding the wood charcoal).

\section{$41 L N 320$}

This small (30 m diameter) prehistoric site of probable Woodland period age was found on a naturally sandy rise on an alluvial terrace ( 310 feet amsl) on the north side of Boggy Creek. There are deep sandy sediments here, probably Big Brushy sandy mantle deposits as well as alluvial deposits (Corbin et al. 1994:91). Four 
FIGURE 42. REDACTED

Figure 42. Map of the Clear Cut site.

pieces of lithic debris were collected from three of the 10 shovel tests excavated at the site during these initial investigations (the site form states that only one of seven shovel tests excavated at the site contained prehistoric artifacts), and these were recovered at 25-90 cm bs (Corbin et al. 1994:91 and Table 7). 
According to the SFASU site form, a $1 \times 1 \mathrm{~m}$ unit was also excavated at the site to a depth of $115 \mathrm{~cm}$ bs; whether this unit contained any prehistoric artifacts is not known. The site form also mentions the excavation of a $50 \times 50 \mathrm{~cm}$ unit at $41 \mathrm{LN} 319$, and a possible feature was encountered in it (at an unspecified depth) that had small burned ferruginous sandstone rocks and small pieces of wood charcoal. The locations of these units are not known with any certainty.

The 2010 relocation work determined that $41 \mathrm{LN} 320$ was confined to a small natural rise in an old field (Figure 43). The old field was in tall grasses and bull nettles, and surface visibility was less than $10 \%$. Shovel tests indicated that the extent of the archaeological deposits here was ca. $25 \times 20 \mathrm{~m}$ (0.12 acres).

During the 2010 archaeological investigations, a small amount of prehistoric artifacts were recovered in two shovel tests and the $50 \times 50 \mathrm{~cm}$ unit excavations at $41 \mathrm{LN} 320$ (see Figure 43). These artifacts were found at a depth of 60-100 cm bs in Hearne fine sandy loam sediments in the shovel tests, suggesting that a buried component was present at the site, but unfortunately, prehistoric artifacts were only found to depths of 0-20 cm in Unit 320. This disparity in the depth and thickness of the archaeological deposits also suggests that there is considerable variability in the thickness of the sandy mantle deposits here, as well as localized erosion and removal of portions of the sandy mantle. The artifact density in the shovel tests is 1.0 per positive shovel test (ca. 8 artifacts per $\mathrm{m}^{2}$ ), and only 8 artifacts per $\mathrm{m}^{2}$ in Unit 320 .

Lithic artifacts in the small sample include two pieces of non-cortical chert debris, grayish-brown chert $(n=1)$ and gray chert $(n=1)$, as well as a petrified wood core fragment (Unit 320, 0-10 c bs); the core has stream-rolled cortical remnants. A single thin $(5.1 \mathrm{~mm}$ ) sandy paste body sherd (Goose Creek Plain, var. unspecified) of probable Woodland period age was found at $60-80 \mathrm{~cm}$ bs in ST 359 .

\section{LN323, Sweetgum Site}

The Sweetgum site (4lLN323) was recorded as a prehistoric Woodland and Late Prehistoric period site located on a naturally sandy rise (261 feet amsl) in the Boggy Creek floodplain; the estimated site size was $100 \mathrm{~m}$ in diameter (Corbin et al. 1994:92-93). A 1933 USDA aerial photograph discerned what may be the signature of a circular prehistoric house structure and other features. Twenty-eight shovel tests were excavated at the site by Corbin et al. (1994), and 14 of them contained prehistoric lithic and ceramic sherds at 50-110 cm bs. The site form mentioned that a charcoal lens was exposed at $50 \mathrm{~cm}$ bs in the shovel testing, but the location or number of shovel tests with the charcoal lens was not specified. Furthermore, no confirmation was apparently obtained in the shovel testing done at that time that there was a prehistoric house structure stain at the site.

The lithic artifacts included 62 pieces of lithic debris and a broken quartzite biface (Corbin et al. 1994:1 11 and Table 7), as well as fire-cracked rock. The site description mentioned that Woodland period sandy paste sherds $(n=2)$ were found in the shovel testing, but Corbin et al. (1994:121 and Table 3) also mentioned a bone-tempered engraved Caddo body sherd that had been decorated with two parallel engraved lines.

The floodplain rise at the presumed Sweetgum site plotted location was readily identified. Shovel tests $(n=19)$ across the rise along the edge of the Boggy Creek floodplain confirmed that this was the location of the site, and that it contained deep prehistoric archaeological deposits (Figure 44). The landform has several large oak trees, as well as an understory of yaupon holly and american beauty bushes; surface visibility was less than $10 \%$. 
FIGURE 43. REDACTED

Figure 43. Map of 41 LN320. 
FIGURE 44. REDACTED

Figure 44. Map of the Sweetgum site. 
The site extent as established in the shovel testing at the Sweetgum site is ca. $2100 \mathrm{~m}$ ( 0.5 acres). During the 2010 archaeological investigations at the site, nine shovel tests and Unit 323 were found to contain prehistoric archaeological deposits (see Figure 44). The archaeological deposits ranged from $20 \mathrm{~cm}$ to $100 \mathrm{~cm}$ bs in depth in the Hearne fine sandy loam sediments, with the thickest deposits in the southern and western part of the site (ST 588, ST 591, and Unit 323). Artifact density in the shovel tests, including nutshells $(n=2)$, is 5.0 per positive shovel test or 40.0 artifacts per $\mathrm{m}^{2}$. In Unit 323 , also including nutshells (n $=2$ ), the artifact density is 76.0 per $\mathrm{m}^{2}$. Artifacts were most common between 30 and $50 \mathrm{~cm}$ bs.

One of the recovered artifacts from the Sweetgum site is a plain sandy paste Goose Creek Plain, var. unspecified body sherd ( $6.6 \mathrm{~mm}$ thick) from Unit $323(30-40 \mathrm{~cm}$ bs). The sherd is from a vessel that received no surface treatment, and had been incompletely oxidized during firing (see Teltser 1993:Figure 2e). This sherd may be reflective of the Woodland period component identified in the earlier work, as is a petrified wood Gary point preform from ST $591(80-100 \mathrm{~cm}$ bs). The preform has a rough cortex on both faces, suggesting the raw material was obtained from a bedrock source), and is $41.1 \mathrm{~mm}$ in length, $20.0 \mathrm{~mm}$ in width, and $10.5 \mathrm{~mm}$ thick.

The remainder of the prehistoric artifacts from the Sweetgum site is pieces of lithic debris from chipped stone tool manufacture, maintenance, and resharpening activities. Various raw materials were employed: quartzite ( $n=20 / 40 \%$ cortical), petrified wood ( $n=3 / 0 \%$ cortical), and different colors of chert: grayish-brown ( $n=1 / 100 \%$ cortical), light gray ( $n=6 / 0 \%$ cortical), gray ( $n=6 / 50 \%$ cortical), dark gray ( $n=1 / 0 \%$ cortical), reddish-brown ( $n=1 / 100 \%$ cortical), brown ( $n=1 / 100 \%$ cortical), and dark brown ( $n=1 / 0 \%$ cortical). Quartzite and gray chert pebbles and cobbles were apparently gathered from stream gravels and brought back to the site for reduction, producing high proportions of cortical flakes. Lithic debris from other raw materials that do not have cortex may have been produced when completed or nearcompleted tools were shaped and/or resharpened

One light gray chert flake from Unit $323(10-20 \mathrm{~cm}$ bs) is a distinctive wedge-shape, like pieces of lithic debris from 41LN308, the Dogwood Beaver site (4lLN316), and the Sweetgum site (41LN323). As previously mentioned, Shafer (2011:99) has identified wedge-shaped flakes from several Early Caddo period contexts in East Texas, suggesting that this Caddo knapping technology may have been in use during the site's occupation.

\section{LN325, Black Finger Tip Site}

This prehistoric habitation site of Woodland and Late Prehistoric age was reported to have been located on a natural sandy rise on an alluvial terrace or floodplain (265 feet amsl) along the north side of Boggy Creek; an old channel of the creek was $40 \mathrm{~m}$ to the south (Corbin et al. 1994:93 and Figure 21). A dark brown organic stain or midden deposit that was a ca. $30 \mathrm{~m}$ in diameter was present at the southern end of the rise. Site size was estimated at ca. 150 × $80 \mathrm{~m}$ (ca. 3.0 acres).

A total of 34 shovel tests were excavated at 41 LN325 during the initial site recording effort, and although the number of shovel tests that contained prehistoric artifacts was not noted, lithic debris $(\mathrm{n}=106)$, one lithic core, four sandy paste Goose Creek Plain sherds, and three bone-tempered sherds (see Corbin et al. 1994:Tables 3 and 7) were recovered from a depth of 14-120 cm bs; charred nutshells, wood charcoal, and fire-cracked rock were apparently also present, but they were not noted as being collected (Corbin et al. 1994:93 and Table 7). One of the bone-tempered sherds, a rim sherd likely from a carinated bowl, was engraved with opposed lines on either side of an excised triangle element (Corbin et al. 1994:Figure 34). 
Although it was described as a "Late Caddoan [sic] style" engraved sherd by Corbin et al. (1994:Figure 34), it appears more plausibly on stylistic grounds to be from an Early Caddo style (ca. pre-A.D. 1300) Holly Fine Engraved vessel (see Suhm and Jelks 1962:Plate 39e, g, i) than any specific Late Caddo pottery type.

Extensive shovel testing $(n=38)$ on the alluvial landform on the north side of Boggy Creek, and which projected into the Boggy Creek floodplain, led to the relocation of the Black Finger tip site in 2010 (Figure 45). The landform has an overstory of hardwoods with a thick understory of yaupon holly and mustang grapevines. Surface visibility across the site is less than $10 \%$.

Shovel testing at the site located a prehistoric midden deposit (very dark grayish-brown to dark brown in color, with organic staining) at the southern tip of the landform. The midden is $20 \mathrm{~m}$ in diameter and ranges from $80 \mathrm{~cm}$ to more than $100 \mathrm{~cm}$ in thickness in ST 608, ST 609, ST 635, and ST 636, and $82 \mathrm{~cm}$ in thickness in Unit 325 (see Figure 45). The primary constituents of the midden are lithic debris, hickory nutshell, acorn nut meat, animal bone, (see Appendix 5), hickory wood charcoal (see Appendix 6), and burned clay.

Two radiocarbon dates have been obtained from a single charred hickory nutshell from midden deposits (UCIAMS-95420) and a single charred nutshell beneath the midden (UCIAMS-95421) at the Black Finger Tip site (Table A6.2). As with the $41 \mathrm{LN} 308$ dates, OxCal, version 4.1.7 (Bronk Ramsey 2009) and IntCal 09 (Reimer et al. 2009) were used to calibrate the dates and determine the 2 sigma relative area under the probability distribution for each of the two dates.

The two sigma calibrated age range of the hickory shell from near the top of the midden at the Black Finger tip site is A.D. 664-720 and A.D. 748-764, during the latter part of the Woodland period. These calibrated age ranges suggest that much of the midden deposits accumulated during the Woodland period. The two sigma calibrated age range of the hickory shell from archaeological deposits below the midden is 824-904 B.C., during the latter part of the Archaic period. The midden apparently began to accumulate sometime after this calibrated age range.

During the 2010 archaeological investigations at Fort Boggy State Park, a total of 26 shovel tests and Unit 325 were found to contain prehistoric archaeological deposits (see Figure 45 and Table 11). One of the shovel tests (ST 619) and Unit $325(0-10 \mathrm{~cm}$ bs) also contained historical archaeological material remains. The site is estimated to cover a $18,900 \mathrm{~m}^{2}$ area (4.7 acres).

The prehistoric archaeological deposits range from $20 \mathrm{~cm}$ to $100 \mathrm{~cm}+\mathrm{bs}$ in Rader fine sandy loam sediments, with the deepest deposits found primarily in the southern and northern parts of the site; two shovel tests in the central part of the site (ST 611 and ST 619) also have prehistoric deposits of at least 100 $\mathrm{cm}$ thickness. Shovel tests with archaeological deposits that are less than $40 \mathrm{~cm}$ thick occur only in the central (ST 628) and northern (ST 630,631, and 640) parts of the site. The historical artifacts were found at 0-20 cm bs and 60-80 cm bs in ST 619 (see Figure 45).

The density of prehistoric artifacts, including nutshells $(n=75)$, wood charcoal $(n=20)$, and animal bones $(n=36)$ from the archaeological deposits at the Black Finger Tip site is substantial, and higher than any of the prehistoric sites/components at Fort Boggy State Park. In the shovel testing, the prehistoric artifact density is 8.8 per positive shovel test or 70.4 artifacts per $\mathrm{m}^{2}$. The highest artifact densities in the shovel tests occur in ST 608-61 1, ST 627, ST 635-636, and ST 638-639 in the southern and central parts of the site (see 
FIGURE 46. REDACTED

Figure 45. Map of the Black Finger Tip site. 
Table 11 and Figure 45). In Unit 325, the prehistoric artifact density is a very high 356.0 per $\mathrm{m}^{2}$ in the midden deposits. Prehistoric artifacts are concentrated in the $10-30 \mathrm{~cm}$ bs level as well as in the $40-90 \mathrm{~cm}$ bs levels, suggesting the presence of two stratigraphically distinct components; both of these components are likely to be of Woodland period age. The density of historical artifacts is 3.0 in the one positive shovel test $(24.0$ artifacts per $\mathrm{m}^{2}$ ) and 4.0 per $\mathrm{m}^{2}$ in Unit 325 .

Table 11. Distribution of prehistoric artifacts at the Black Finger Tip site.

\begin{tabular}{|c|c|c|c|c|c|c|c|c|c|c|}
\hline PROVENIENCE & DS & PS & AP & FT & GS & $\mathrm{LD}$ & BC & NS & WC & $A B$ \\
\hline ST 608 & - & 2 & - & - & - & 10 & 1 & 2 & 3 & 4 \\
\hline ST 609 & - & - & - & - & - & 4 & - & 12 & 4 & - \\
\hline ST 610 & 1 & 1 & - & - & - & 10 & - & 4 & 1 & - \\
\hline ST 611 & 1 & - & - & - & - & 7 & - & 7 & - & - \\
\hline ST 612 & - & 1 & 1 & - & - & 6 & - & 3 & - & - \\
\hline ST 613 & - & - & - & - & - & 2 & - & 3 & - & - \\
\hline ST 614 & - & - & - & - & - & 1 & - & 2 & - & - \\
\hline ST 616 & - & - & - & - & - & 3 & - & - & - & - \\
\hline ST 617 & - & - & - & - & - & 6 & - & - & - & - \\
\hline ST 618 & - & 1 & - & 1 & - & 7 & - & 2 & - & - \\
\hline ST 619 & - & - & - & - & - & 6 & - & - & - & - \\
\hline ST 620 & - & - & 1 & - & - & 6 & - & - & - & - \\
\hline ST 621 & - & 2 & - & - & 1 & 3 & - & - & - & - \\
\hline ST 624 & - & 1 & - & - & - & 2 & - & - & - & - \\
\hline ST 626 & 1 & 2 & - & - & - & 3 & - & - & - & - \\
\hline ST 627 & - & 1 & - & - & - & 11 & - & - & - & 1 \\
\hline ST 628 & - & 1 & - & - & - & 2 & - & - & - & - \\
\hline ST 629 & - & - & - & - & - & 3 & - & - & - & - \\
\hline ST 630 & - & - & - & - & - & 1 & - & - & - & - \\
\hline ST 631 & - & - & - & - & - & 1 & - & - & - & - \\
\hline ST 632 & - & - & - & - & - & 4 & - & - & - & - \\
\hline ST 635 & - & - & - & - & - & 8 & - & 10 & - & 4 \\
\hline ST 636 & - & - & - & - & - & 6 & 3 & 4 & - & - \\
\hline ST 638 & 1 & 1 & - & - & - & 6 & - & 4 & - & - \\
\hline ST 639 & - & - & - & - & - & 8 & - & 5 & - & - \\
\hline ST 642 & - & - & - & - & - & 2 & - & - & - & - \\
\hline ST 643 & - & - & - & - & - & 3 & - & - & - & - \\
\hline Unit 325 & 1 & 1 & - & 1 & - & 18 & 11 & 17 & 12 & 27 \\
\hline Totals & 5 & 14 & 2 & 2 & 1 & 149 & 15 & 75 & 20 & 36 \\
\hline
\end{tabular}


Nutshell and wood charcoal was recovered in shovel tests and Unit 325 in the southern and central parts of the Black Finger Tip site (see Table 11); the highest densities of these paleobotanical remains are in shovel tests near the southern tip of the landform, in prehistoric Woodland period midden deposits. Pieces of animal bone are found in the midden deposits at the southern tip of the landform, in densities ranging between 8 and 108 pieces per $\mathrm{m}^{2}$.

There are four chipped stone tools in the Black Finger Tip site lithic assemblage: two arrow point fragments and two expedient flake tools (see Table 11). The two arrow points are from shovel tests (ST $612,60-80 \mathrm{~cm}$ bs and ST $620,20-40 \mathrm{~cm} \mathrm{bs}$ ) in the central part of the site. The first arrow point may be a contracting stem Perdiz point made from a light gray chert (Figure 46a), although the stem is broken. It is bifacially flaked, has serrated blades, and expanding barbs. The length of the blade is $18.3 \mathrm{~mm}$ in length, $17.1 \mathrm{~mm}$ in width, $2.9 \mathrm{~mm}$ thick, and has a $4.5 \mathrm{~mm}$ stem width. The occurrence of a Perdiz point on the site implies that it was also occupied after ca. A.D. 1200, and this occupation may have lasted into the seventeenth century (Turner and Hester 1999:227). The second arrow point is a tip/blade fragment made from a grayish-brown chert (Figure 46b). It has a serrated blade (perhaps suggesting it might also be a Perdiz arrow point) that is $2.1 \mathrm{~mm}$ thick.

Both of the chipped stone flake tools are from the southern part of the site, one in the midden deposits at the southern tip of the landform (Unit 325, 90-100 cm bs), and the second from ST 618 (60-80 cm bs) (see Figure 45). Both are expedient flake tools with unilateral (cortical grayish-brown chert) or bilateral (cortical brown chert) use-wear/retouch. The range of use-wear lengths is 7.0-20.0 mm on these flake tools.

The lithic debris ( $n=149$, including one core) from the Black Finger Tip site was derived from the reduction of both locally available quartzite and petrified wood pebbles and cobbles for tool manufacture, as well as a wide variety of cherts, some of local origin, and others likely from Central Texas sources (see Gadus et al. 2002:Table 2). The one core (ST 638, 20-40 cm bs) is a multi-platform flake core with smooth cortical remnants on a light gray chert. The core is $21.2 \mathrm{~mm}$ in length, $22.0 \mathrm{~mm}$ in width, and $7.8 \mathrm{~mm}$ thick.

Raw material frequencies and the proportion of cortical flakes among the lithic debris are as follows: quartzite ( $n=17 / 59 \%$ cortical), petrified wood ( $n=29 / 31 \%$ cortical), chalcedony ( $n=1 / 0 \%$ cortical), red chert ( $n=8 / 25 \%$ cortical), dark red chert $(n=1 / 0 \%$ cortical), brown chert ( $n=9 / 56 \%$ cortical), reddishbrown chert ( $n=1 / 100 \%$ cortical), yellowish-brown chert $(n=2 / 50 \%$ cortical), yellowish-gray chert $(n=1 / 0 \%$ cortical), brownish-gray chert ( $n=6 / 0 \%$ cortical), grayish-brown chert ( $n=2 / 0 \%$ cortical), reddish-gray chert ( $n=1 / 0 \%$ cortical), dark brown chert ( $n=4 / 0 \%$ cortical), light gray chert ( $n=13 / 8 \%$ cortical), gray chert $(n=$ $34 / 12 \%$ cortical, one of the cortical flakes is limestone-covered), dark gray chert ( $n=12 / 8 \%$ cortical), grayishwhite chert ( $n=1 / 0 \%$ cortical), and white chert ( $n=1 / 0 \%$ cortical). One of the quartzite flakes is wedgeshaped, perhaps derived from a technology seen in Early Caddo knapping (see Shafer 2011).

The most common raw materials employed in chipped stone tool manufacture and maintenance/ resharpening at the Black Finger Tip site are gray chert (23\%), petrified wood (20\%), quartzite (11\%), light gray chert $(9 \%)$, and dark gray chert ( $8 \%)$. Quartzite, petrified wood, and chalcedony together constitute $32 \%$ of the debris, while cherts of different colors and origins account for the remaining $68 \%$ of the lithic debris sample. In the clearly local raw materials (quartzite, petrified wood, and chalcedony), more than $40 \%$ of the debris have cortex, suggesting that these materials were obtained near the site and reduced there for tool production using flakes suitable for arrow points and flake tools. The proportion of cortical flakes in the earth-toned cherts (red, dark red, brown, reddish-brown, and yellowish-brown) is $53 \%$, and these materials 


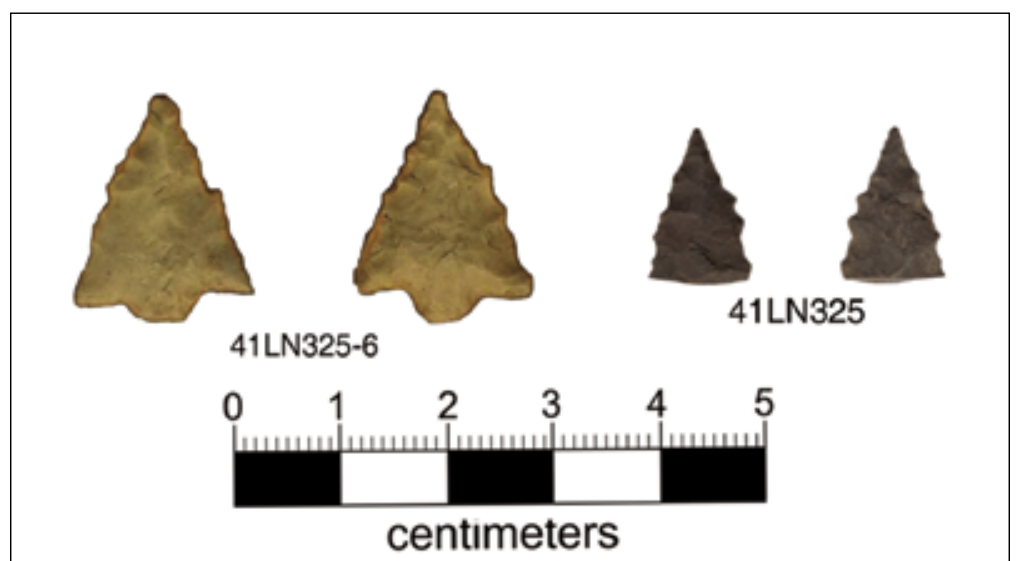

Figure 46. Arrow points from the Black Finger Tip site (41LN325): $a$, possible Perdiz; b, tip and blade fragment. were likely also collected from a nearby and local gravel source, and reduced on site during knapping tools. In the other cherts (see above)-mainly gray, dark brown, white, and various combinations, but dominated by the gray chert raw material-cortex-covered lithic debris pieces represent only $8 \%$ of the sample. These pieces of lithic debris, accounting for more than $50 \%$ of the entire lithic debris assemblage, are most likely from non-local sources, almost certainly of Central Texas derivation.

The one ground stone tool is from ST $621(0-20 \mathrm{~cm} \mathrm{bs})$ in the central part of the site (see Figure 45). It is a quartzite mano with one grinding surface. The mano is $54.8 \mathrm{~mm}$ in length, $67.0 \mathrm{~mm}$ in width, and $46.1 \mathrm{~mm}$ thick.

The prehistoric ceramic assemblage from the Black Finger Tip site is the largest ( $n=19$ sherds) of the Fort Boggy State Park sites investigated in 2010 (Table 12). This includes four rim sherds, 12 body sherds, and three base sherds. Given the small size of the ceramic assemblage, there are a number of temper and paste classes represented in these sherds: sandy paste $(n=4)$, grog-tempered-sandy paste $(n=4)$, bonetempered-sandy paste $(n=2)$, grog-bone-tempered-sandy paste $(n=1)$, grog-hematite-tempered-sandy paste $(n=2)$, no temper-clayey-silty paste $(n=1)$, grog-tempered-clayey-silty paste $(n=4)$, and bonetempered-clayey-silty paste $(n=1)$. Sherds with a sandy paste (with or without temper) constitute $68 \%$ of the assemblage, and the sherds with a clayey-silty paste (with or without temper) account for the remaining $32 \%$ of the assemblage. Of those sherds that are tempered $(n=14)$ and that have either one or two kinds of temper, $79 \%$ have grog inclusions, $28 \%$ have bone inclusions, and 14\% have crushed hematite inclusions.

Table 12. Plain and decorated sherds from the Black Finger Tip site.

\begin{tabular}{|c|c|c|c|c|}
\hline PROVEnIENCE (CM BS) & SHERD TYPE & TEMPER & PASTE & DECORATION \\
\hline \multirow[t]{2}{*}{ ST 608, 60-80 } & body & - & sandy & plain \\
\hline & body & - & sandy & plain \\
\hline ST $610,20-40$ & rim & bone-grog & sandy & plain \\
\hline ST $610,40-60$ & rim & grog & clayey-silty & horizontal incised lines \\
\hline ST $611,60-80$ & body & grog & clayey-silty & $\begin{array}{l}\text { parallel incised lines and } \\
\text { faint opposed brushing }\end{array}$ \\
\hline ST $612,60-80$ & body & - & sandy & plain \\
\hline ST $618,40-60$ & body & grog & sandy & plain \\
\hline ST $621,40-60$ & base & bone & sandy & plain \\
\hline ST $621,80-100$ & base & - & clayey/silty & plain \\
\hline ST $624,80-100$ & base & grog-hematite & sandy & plain \\
\hline
\end{tabular}


Table 12, continued.

\begin{tabular}{lllll}
\hline PROVEnIENCE (CM BS) & SHERD TYPE & \multicolumn{1}{c}{ TEMPER } & \multicolumn{1}{c}{ PASTE } & \multicolumn{1}{c}{ DeCORATiON } \\
\hline ST 626, 0-20 & rim & - & sandy & possible lip notched \\
& body & grog & sandy & plain \\
& body & grog & sandy & plain \\
ST 627, 0-20 & body & grog-hematite & sandy & plain \\
ST 628, 0-20 & rim & bone & sandy & plain \\
ST 638, 20-40 & body & grog & clayey-silty & parallel incised lines \\
ST 638, 40-60 & body & grog & sandy & plain \\
Unit 325, 0-10 & body & bone & clayey-silty & plain \\
Unit 325, 20-30 & body & grog & clayey-silty & opposed incised lines \\
\hline
\end{tabular}

The sandy paste sherds from the Black Finger Tip site are from the central and southern parts of the site, and occur from depths of $0-20 \mathrm{~cm}$ to $60-80 \mathrm{~cm}$ bs. The sandy paste sherds are from vessels fired in a reducing or low oxygen environment, and have been smoothed on either one or both vessel surfaces. Body sherds are thin-walled, 5.4-6.3 $\mathrm{mm}$ thick, with a mean thickness of $5.8 \pm 0.5 \mathrm{~mm}$. One of the sherds is a rim (8.4 mm thick) that appears to have been lip notched, but it is eroded. Lip-notched sandy paste sherds in the Woodland period sandy paste pottery assemblages from Lake Naconiche in East Texas-otherwise dominated by plain vessels, as are all Mossy Grove sites-come from archaeological deposits dated at 2230-1830 years B.P., during the early part of the Woodland period (Perttula 2008). Ellis (2010:45) indicates, however, that lip notched sherds also have been found on Late Prehistoric sites along the Texas Gulf Coast in southeast Texas, particularly on sites in the Middle Coast, so the temporal context of the Black Finger Tip site lip notched rim sherd remains uncertain.

The flat base sherd ( $11.7 \mathrm{~mm}$ thick) from a non-tempered vessel is from ST 621 (80-100 cm bs) in the central part of the site. This base sherd was from a vessel that was fired in a reducing environment and cooled in the open air (see Teltser 1993:Figure 2f).

Almost half of the sherds from the Black Finger Tip site are sandy paste sherds with temper inclusions, either grog, bone, or hematite. The bone-grog-tempered sandy paste sherd is from ST $610(20-40 \mathrm{~cm}$ bs) in the central part of the site (see Figure 45). It is a plain rim sherd (with a direct rim profile and a rounded lip) (Figure 47a) that has been burnished on its interior surface; the vessel was fired and cooled in a reducing environment (see Teltser 1993:Figure 2b). Rim walls are $8.1 \mathrm{~mm}$ in thickness.

The plain bone-tempered sandy paste sherds are from two shovel tests in the central part of the site (ST 621 and ST 628, 0-20 cm bs and 40-60 cm bs). One is a rim with a direct profile and a rounded, exterior folded lip, with $7.6 \mathrm{~mm}$ thick walls; it has been smoothed on both interior and exterior surfaces. The other is a flat base sherd (10.5 mm thick). The sherds are from two different vessels fired in a reducing environment. The plain grog-hematite-tempered sandy paste sherds are from the southern part of the site (ST 624 and ST 627 , from $0-20 \mathrm{~cm}$ bs and $80-100 \mathrm{~cm}$ bs. One is a large circular but flat base sherd (Figure 48) that is $8.2 \mathrm{~cm}$ in diameter and $11.3 \mathrm{~mm}$ thick; it has been smoothed on its exterior surface. It is from a vessel, probably a jar, that was fired in a reducing environment and cooled in the open air. The second grog-hematitetempered sandy paste sherd is from the body ( $7.2 \mathrm{~mm}$ thick) of a vessel that was incompletely oxidized during firing (see Teltser 1993:Figure 2d). 


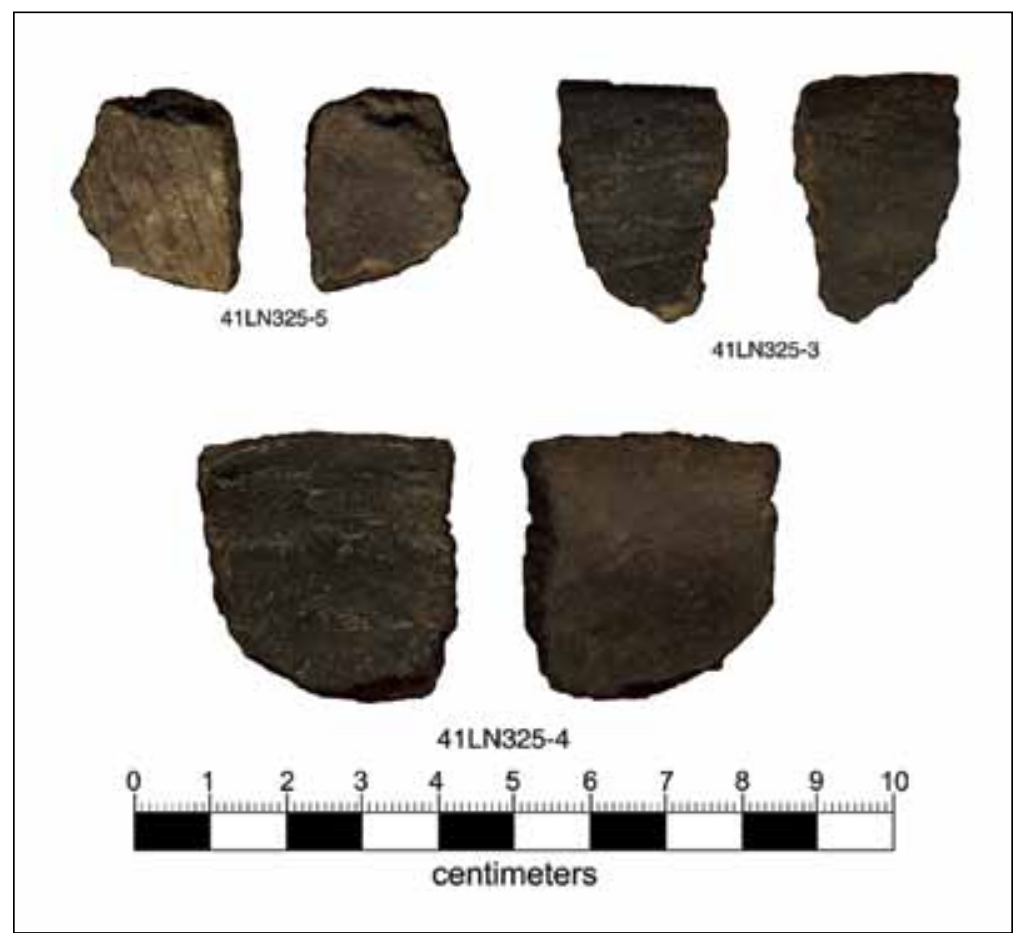

Figure 47. Plain and decorated sherds from the Black Finger Tip site (41LN325): a, plain rim; b, horizontal incised rim; c, parallel incised body sherd.

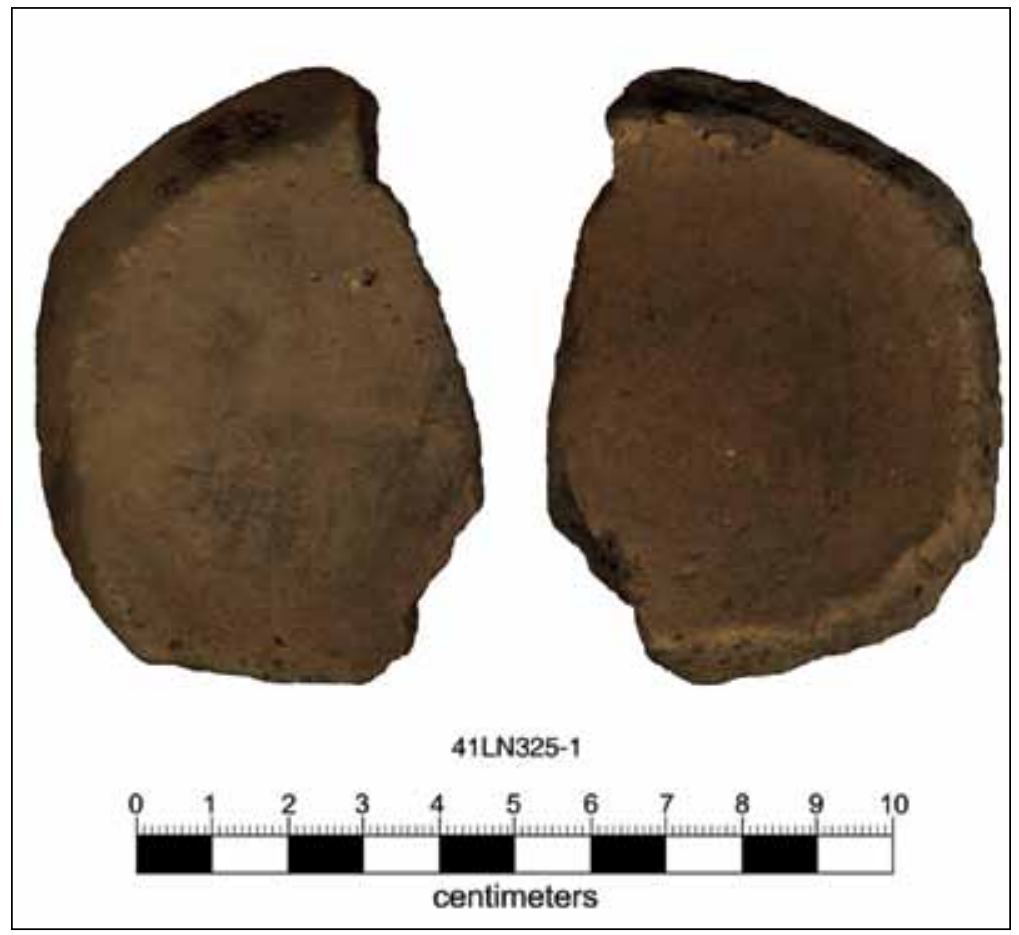

Figure 48. Base sherd from the Black Finger Tip site (41LN325).
The grog-tempered sandy paste sherds are from both central (ST 638) and southern (ST 618 and ST 626) parts of the site, and from depths of $0-20 \mathrm{~cm}$ bs and 40-60 cm bs (see Table 12). They are plain, and $50 \%$ have interior-exterior surface burnishing and/or floating. Based on the firing conditions, each sherd is from a different vessel. Three of the sherds are from vessels fired in a reducing environment, with two of them subsequently cooled in the open air. The other sherd was from an incompletely oxidized vessel (see Teltser 1993:Figure 2e). The grog-tempered sandy paste sherds have moderately thick vessel walls, with a mean thickness of $7.43 \pm 0.48$ $\mathrm{mm}$ and a range of 6.9-8.2 $\mathrm{mm}$.

The non-sandy paste and tempered sherds in the Black Finger Tip site ceramic sherds account for only $26 \%$ of the assemblage. The plain bone-tempered body sherd (7.0 mm thick), from the southern part of the site (Unit 325, 0-10 $\mathrm{cm}$ bs), came from a vessel that was fired in a reducing environment and cooled in the open air (see Teltser 1993:Figure 2g).

The grog-tempered sherds are from both the central (ST 610, ST 611, and ST 638) and southern (Unit 325) parts of the site, and from depths of $20-80 \mathrm{~cm}$ bs. All four of the grog-tempered clayey to silty paste sherds are from decorated vessels. Three have incised decorations on the rim and upper body, including an opposed line element (Unit 325, 20-30 cm bs), a horizontal incised rim (see Figure $47 \mathrm{~b}$ ) from ST 610 (40-60 cm bs), and a sherd with parallel incised lines (see Figure 47c, ST $638,20-40 \mathrm{~cm}$ bs). The last decorated grog-tempered sherd (ST 611, 60-80 
$\mathrm{cm}$ ) has faint opposed brushed marks on the body, while the lower rim appears to have a series of vertical incised lines. The presence of a brushed sherd in the Black Finger Tip site ceramic assemblage points to at least some use of the site after ca. A. D. 1200, which is in concordance with the previously mentioned Perdiz point also recovered in the archaeological deposits.

Three of the four grog-tempered sherds were from vessels fired and cooled in a reducing environment, while the other was from an incompletely oxidized vessel. Two of the sherds have been either smoothed or burnished on interior surfaces. The one rim sherd (7.2 $\mathrm{mm}$ thick) has a direct rim profile and a rounded lip. The range of wall thickness of three body sherds is $5.5-7.5 \mathrm{~mm}$, with a mean thickness of $6.7 \pm 0.8 \mathrm{~mm}$.

The diversity in temper-paste classes in the ceramics at the Black Finger Tip site is impressive, as is the dominance of Woodland period sandy paste sherds and non-sandy paste decorated sherds with resemblances to Caddo decorated pottery made in East Texas. The spatial and vertical distribution of the different kinds of wares suggests that there may have been two prehistoric occupations at the site where the peoples made and used pottery vessels. In the southern part of the site, plain sandy paste and plain grogand grog-hematite-tempered sherds are found at 30-100 cm bs, and this may be the earliest occupation in this area; the one radiocarbon date from the upper part of the midden deposits $(20-40 \mathrm{~cm}$ bs) suggests that these sherds predate ca. A.D. 800. Possible later ceramics in this area (0-30 cm bs) include an incised grog-tempered and plain bone-tempered sherds, plain grog-tempered sandy paste sherds, and plain groghematite-tempered sandy paste sherds, as well as the sandy paste lip notched rim sherd, and may date after ca. A.D. 800. Conversely, in the central part of the site, the deepest and perhaps oldest sherds are from 80-100 cm bs, but this only includes a base sherd with no apparent temper. From 0-80 cm bs in this area, however, there are three decorated grog-tempered sherds that may be part of a component that dates after ca. A.D. 1200 (because one of them has a brushed decoration). This possible component does have bonetempered sandy paste, grog-bone-tempered sandy paste, grog-bone-tempered sandy paste, and sandy paste (from 60-80 cm bs) sherds. Radiocarbon dates from each of these deposits are warranted to refine the temporal character of the Black Finger Tip ceramic wares and assemblage.

As previously mentioned, the historical artifacts $(n=4)$ from the Black Finger Tip site are from ST 619 $(0-20 \mathrm{~cm}$ bs and $60-80 \mathrm{~cm}$ bs) in the central part of the site. They include three pre-1880 olive green bottle glass sherds and a thin $(1.3 \mathrm{~mm})$ piece of aqua-colored window glass from Unit $325(0-10 \mathrm{~cm}$ bs). Moir's (1987) regression equation suggests this window glass sherd was from a pane of glass manufactured in $1822.58 \pm 7$, which seems anomalously early. Nevertheless, the olive green bottle glass and thin window glass found at the site suggest there was a transitory use of the site in the nineteenth century.

\section{LN326, Boggy Bridge Site}

41LN326 was recorded as a small ( $40 \mathrm{~m}$ in diameter, 0.4 acres) Woodland period site with sandy archaeological deposits that ranged between 4 and $170 \mathrm{~cm}$ bs in thickness. This site was situated on the southern edge of a large alluvial terrace and/or alluvial fan (280 feet amsl), not far from the Boggy Creek channel or its floodplain. Shovel testing $(n=22)$ recovered lithic debris $(n=19)$ and three plain sandy paste Goose Creek Plain, var. unspecified sherds (Corbin et al. 1994:94 and Table 7), and fire-cracked rock and burned clay are mentioned on the site form as being recovered from a post hole dug shovel test. The depth of artifact recovery was 50-100 cm bs, again as mentioned on the site form. 
During a 1997 seismic survey project at Fort Boggy State Park, two new shovel tests were excavated at the Boggy Bridge site, and they contained lithic debris to below $70 \mathrm{~cm}$ bs. These shovel tests expanded the estimated size of the site to $80 \mathrm{~m}$ in diameter (1.6 acres) (Corbin 1997:3).

In 2010, the alluvial terrace landform at the Boggy Bridge site had a few hardwoods, and the ground cover was dominated by grasses and bull nettles. Surface visibility was less than $10 \%$. Extensive shovel testing $(n=19)$ on the landform identified prehistoric archaeological deposits that cover a 50 x $30 \mathrm{~m}$ area (0.4 acres) (Figure 49).

The 2010 shovel testing and 50 x $50 \mathrm{~cm}$ unit excavations recovered only lithic debris $(\mathrm{n}=6)$, firecracked rock ( $n=1,80-100 \mathrm{~cm}$ bs in ST 658) (see Figure 49), and charred nutshells $(n=1)$ in deposits that range from $20 \mathrm{~cm}$ bs to $100 \mathrm{~cm}$ bs in Rader fine sandy loam sediments; $87.5 \%$ of the artifacts came from 50-100 cm bs. We were unable to confirm that the site was occupied in the Woodland period because no temporally diagnostic artifacts were recovered in our work. The density is low: 1.67 per positive shovel test (ca. 13.4 artifacts per $\mathrm{m}^{2}$ ) and 12.0 artifacts per $\mathrm{m}^{2}$ in Unit 326. Raw material represented in the lithic debris includes petrified wood ( $2 / 100 \%$ cortical), heat-treated quartzite $(n=2 / 50 \%$ cortical) and gray chert $(n=$ $2 / 0 \%$ cortical). The cortical flakes are from stream-rolled cobbles and pebbles that were reduced on the site, perhaps during the initial knapping of a pebble or stream cobble.

\section{LN328, Bull Nettle Alley Site}

This prehistoric site of unknown age was located on the large alluvial terrace (310 feet amsl) north of Boggy Creek; Corbin et al. (1994:94) inexplicably described the landform setting as a west-facing slope. It was estimated to cover a $60 \mathrm{~m}$ diameter area ( 0.9 acres), and a soil discoloration (a possible midden or structure area?) was noted on a 1933 USDA aerial photograph (Corbin et al. 1994:94). Twenty shovel tests were excavated at the site, but they recovered only a low density of lithic debris $(n=7)$ (Corbin et al. 1994:Table 7), wood charcoal, and burned rock to a depth of $100 \mathrm{~cm}$ bs.

The Bull Nettle Alley site as relocated in 2010 was small ( $800 \mathrm{~m}$ or 0.2 acres) in size, and situated on an alluvial terrace landform with hardwoods (Figure 50). The understory was yaupon holly. Open areas on the landform had grasses and bull nettle. Surface visibility was less than $10 \%$.

Additional prehistoric lithic artifacts (lithic debris only) of unknown age were recovered in two of the 12 shovel tests excavated across the landform as well as in the $50 \times 50 \mathrm{~cm}$ unit (Unit 328) at the Bull Nettle Alley site during the 2010 work (see Figure 50). They were found at $20-100 \mathrm{~cm}$ bs in Silstid loamy fine sand sediments. The density of prehistoric artifacts is low: 2.0 per positive shovel test (ca. 16.0 artifacts per $\left.\mathrm{m}^{2}\right)$ and only 4.0 artifacts per $\mathrm{m}^{2}$ in Unit 326. The five pieces of lithic debris are from quartzite $(\mathrm{n}=2 / 50 \%$ cortical), chalcedony ( $n=1 / 0 \%$ cortical), and light gray/gray chert $(n=2 / 0 \%$ cortical) raw materials.

\section{$41 L N 329$}

Corbin et al. (1994:94-95) described $41 \mathrm{LN} 329$ as being situated on a $30 \mathrm{~m}$ diameter sandy rise on an upland toe slope (275 feet amsl) that extended into the Boggy Creek floodplain. It was occupied during an unknown prehistoric period. Shovel tests excavated at that time $(n=16)$ recovered lithic debris $(n=3)$ and a bifacial tool fragment (Corbin et al. 1994:115 and Figure 30a) made from a red chert at 40-140 cm bs. 
FIGURE 49. REDACTED

Figure 49. Boggy Bridge site map. 
FIGURE 50. REDACTED

Figure 50. Map of the Bull Nettle Alley site.

Shovel testing across this landform in 2010 led to the identification of two small areas at 41 LN328 that have prehistoric archaeological deposits (Figure 51). An old and deep (2-4 m) road cut lies at the southern end of the landform. The spatial discontinuity between them suggests that there are very low 
FIGURE 51. REDACTED

Figure 51. Map of 41 LN329.

density archaeological densities between the two site areas, sufficiently low in density that they could not be identified through shovel testing. The landform is in a hardwood forest with a thick understory of yaupon holly and mustang grapevines, as well as bull nettle and yucca. 
Additional prehistoric lithic artifacts (lithic debris only) of unknown age were recovered in one shovel test and the $50 \times 50 \mathrm{~cm}$ unit (Unit 329) at $41 \mathrm{LN} 329$ during the 2010 work (see Figure 51). Site size is estimated at a maximum of $20 \times 20 \mathrm{~m}$. They were found at $80-100 \mathrm{~cm}$ bs in the Hearne fine sandy loam sediments, suggesting there are relatively deeply buried archaeological deposits at the site. The density of prehistoric artifacts is low, however: 2.0 per positive shovel test (ca. 16.0 artifacts per $\mathrm{m}^{2}$ ) and only 8.0 artifacts per $\mathrm{m}^{2}$ in Unit 326. The four pieces of lithic debris are from heat-treated quartzite ( $n=1 / 100 \%$ cortical), petrified wood ( $n=1,0 \%$ cortical), and brown chert $(n=2 / 50 \%$ cortical) raw materials.

\section{$41 L N 338$}

This prehistoric site of unknown age was located on a south-facing upland slope (300 feet amsl), and covered only an estimated $20 \mathrm{~m}$ diameter area (Corbin et al. 1994:95). In addition to poorly preserved animal bones and teeth, shovel testing $(n=22)$ also recovered one piece of lithic debris at $80-90 \mathrm{~cm}$ bs (Corbin et al. 1994:95 and Table 7).

As a result of the 2010 archaeological investigations, 41 LN338 lies along the eastern boundary of Fort Boggy State Park, adjacent to the U.S. Hwy 75 right-of-way, covering a small area (ca. $15 \times 15 \mathrm{~m}$ ) of a southern-facing upland slope (Figure 52). The site has a hardwood overstory with a thick understory of yaupon holly and mustang grapevines. The western part of the landform is more open, with a ground cover of grasses and bull nettles; surface visibility is less than $10 \%$.

None of the shovel tests $(n=13)$ excavated at $41 \mathrm{LN} 338$, or in its vicinity, in 2010 contained any prehistoric artifacts (see Figure 52), but a low density of lithic debris and wood charcoal was recovered in the $50 \times 50 \mathrm{~cm}$ unit (Unit 338) at $20-40 \mathrm{~cm}$ and $90-100 \mathrm{~cm}$ bs in Hearne fine sandy loam sediments; there may be deeper and more deeply buried archaeological deposits at the site but it is clear that these deposits contain a hard to detect low artifact density. The density of prehistoric artifacts is low: only 16.0 artifacts per $\mathrm{m}^{2}$ in Unit 338, not including the pieces of wood charcoal at $20-40 \mathrm{~cm}$ bs. The four pieces of lithic debris are from heat-treated quartzite ( $n=2 / 0 \%$ cortical) and petrified wood ( $n=2 / 50 \%$ cortical) raw materials. The one cortical piece of petrified wood lithic has a rough cortex, suggesting it was gathered from a local bedrock or non-stream-rolled source.

\section{LN339, Fallen Tree Site}

4lLN339 was reported by Corbin et al. (1994:95) as a prehistoric site of unknown age on a south-facing upland slope (270-280 feet amsl) overlooking the Boggy Creek floodplain. The site, apparently defined by shovel testing, was estimated at that time to be $20 \mathrm{~m}$ in diameter. Only three pieces of lithic debris were recovered at ca. $90 \mathrm{~cm}$ bs in two of the excavated 24 shovel tests.

In the 2010 site relocation effort, shovel testing $(n=12)$ succeeded in looking the Fallen Tree site near an old road cut (Figure 53). The landform has an overstory of hardwoods, with a thick yaupon holly and mustang grapevines understory; surface visibility was less than $10 \%$. The site is ca. $20 \times 20 \mathrm{~m}$ in size.

During the 2010 investigations, a low density of lithic debris and wood charcoal was recovered at 60-100 cm bs in Wolfpen loamy fine sand sediments at the Fallen Tree site in one shovel test and the $50 \times 50$ cm unit (Unit 339) (see Figure 53); there may be deeper and buried archaeological deposits at the site. The density of prehistoric artifacts is only 1.0 per positive shovel test (ca. 8 artifacts per $\mathrm{m}$ ), and 4.0 artifacts per $\mathrm{m}^{2}$ in Unit 339. The two lithic debris are from non-cortical pieces of brown chert and yellowish-gray chert. 
FIGURE 52. REDACTED

Figure 52. Map of $41 \mathrm{LN} 338$.

\section{LN340, Karma Ridge Site}

This site was reported by Corbin et al. (1994:95) to also be a small (30 $\mathrm{m}$ in diameter) prehistoric site of unknown age. It was located on a low sandy rise at the edge of a northwest-facing upland toe slope (290 feet amsl) overlooking the floodplain of an intermittent tributary to Boggy Creek and Boggy Creek. Nineteen shovel tests recovered low densities of lithic debris $(n=4)$ and fire-cracked rocks $(n=4)$ from depths of 30-111 cm bs (Corbin et al. 1994:96 and Table 7). The fire-cracked rock was concentrated in two shovel tests in the northernmost part of the site and the toe slope landform. 
FIGURE 53. REDACTED

Figure 53. Map of the Fallen Tree site.

The Karma Ridge site was relocated in 2010 , and it is situated in a Park area with primitive camp sites and a road/trail (Figure 54). This area has an overstory of hardwoods, and an understory of yaupon holly and mustang grapevines. More open areas have a ground cover of grasses and bull nettle; surface visibility is uniformly less than $10 \%$. 
FIGURE 54. REDACTED

Figure 54. Map of the Karma Ridge site.

In investigations in 2010 at the Karma Ridge site, a moderate density of prehistoric artifacts of unknown age has been recovered from three of 26 shovel tests and Unit 340, the $50 \times 50 \mathrm{~cm}$ unit (see Figure 54). The estimated site size is $20 \times 40 \mathrm{~m}$ ( 0.2 acres). These prehistoric artifacts are from depths of $40-100 \mathrm{~cm}$ bs in Hearne fine sandy loam sediments in the shovel tests, and 10-100 cm bs in Unit 340 sediments. Small pieces 
of fire-cracked rock are relatively common at the site $(n=8,0.60 \mathrm{~kg})$, suggesting some hot rock cooking activities of geophytes (e.g., Thoms 2008b) took place at the site. Also present are pieces of lithic debris $(n=16)$ and charred nutshells $(n=2)$ from $80-90 \mathrm{~cm}$ bs in Unit 340 . The density of prehistoric artifacts is 5.3 per positive shovel test (ca. 42.4 artifacts per $\mathrm{m}^{2}$ ), and 40.0 artifacts per $\mathrm{m}^{2}$ in Unit 340 , including the charred nutshells. The lithic debris are from several different raw materials, including heat-treated quartzite ( $n=13 / 46 \%$ cortical), brown chert ( $n=1 / 100 \%$ cortical), gray chert ( $n=1 / 0 \%$ cortical), and a brownishgray chert ( $n=1 / 0 \%$ cortical). The relative frequency of quartzite use $(81 \%)$ in the lithic debris is notable, suggesting there may have been a nearby stream gravel source, although the sample size is slow. The pieces with cortex were struck off of stream-rolled gravel sources.

\section{LN341, Last Chance Quarry Site}

41 LN34 1 was recorded as a large (250 $\mathrm{m}$ in diameter, ca. 15.6 acres) Woodland and possible Late Prehistoric habitation site and lithic procurement area on a north-facing upland slope (270-300 feet amsl) overlooking the Boggy Creek floodplain (Corbin et al. 194:96-97 and Figure 26). Prehistoric artifacts were visible during the 1992 initial site recording in eroded surface areas across the site as well as recovered to depths of at least $75 \mathrm{~cm}$ bs in 56 shovel tests, two of which were $50 \times 50 \mathrm{~cm}$ in size; prehistoric pottery sherds were concentrated near the lower and northern slope of the upland landform. The lithic procurement areas at the southern end of the site were six areas that may have been dug out along a $100 \mathrm{~m}$ long area of eroded Sparta Sand and Weches Formation outcrop that may have contained siliceous pebbles that could have been used for stone tool knapping (Corbin et al. 1994:96 and Figure 26).

The recovered artifacts consisted of lithic debris $(n=241)$ and cores $(n=7)$, as well as bifacial tools, preforms, and Woodland period style projectile points (Corbin et al. 1994:Figure 29a-b) and fragments, a hammerstone, two ground stone tools (likely pitted stones, but not specified in the report), and fire-cracked rocks $(n=10)$. There were also 10 sandy paste pottery sherds in the artifact assemblage. One of the sandy paste pottery sherds had a single engraved line on it (Corbin et al. 1994:121), suggesting it was the product of a Late Prehistoric occupation, as Woodland and Late Prehistoric period sandy paste pottery in East central Texas is mostly plain (see Story 1990; Ricklis 2004) and unlikely to have been decorated with engraved lines.

When relocated in 2010, the Last Chance Quarry site had been bisected by a gas pipeline right-of-way that cuts north-south across a north-facing upland slope (Figure 55). There was also a plank fenced area and a burned and abandoned feeder. The vegetation on the landform ranges from a hardwood overstory with a thick understory of yaupon holly and mustang grapevines to open areas with grasses and bull nettles. Surface visibility is less than $10 \%$, except in the pipeline right-of-way, where it is $20-30 \%$.

The 2010 archaeological investigations at the Last Chance Quarry site encountered prehistoric archaeological deposits in 10 of 29 shovel tests and Unit 341 (see Figure 55 and Table 13). The site covers an estimated $5600 \mathrm{~m}^{2}$ (1.4 acres). These deposits range in thickness from 20 to $100 \mathrm{~cm}+$ bs in Hearne fine sandy loam sediments, although all but one shovel test (ST 90 in the northern part of the site) had deposits that actually extended to less than $60 \mathrm{~cm}$ bs. The shallowest deposits (a maximum of $20 \mathrm{~cm} \mathrm{bs}$ ) are concentrated in the central part of the site (ST 87, 93, 95, and 101), between the 298 and $300 \mathrm{ft}$. topographic contours. In Unit 341 , the archaeological deposits are a maximum of $50 \mathrm{~cm}$ in thickness from the modern ground surface. Midden deposits (i.e., very dark grayish-brown and organically stained sediments) about $10 \mathrm{~m}$ in diameter 
FIGURE 55. REDACTED

Figure 55. Map of the Last Chance Quarry site. 
were identified in the central part of the site (ST 78-79, ST 100, and Unit 341) that range from 0 to $73 \mathrm{~cm}$ in thickness; the thickest midden deposits are in ST 79. The primary artifactual constituents of these midden deposits are lithic debris, plain sandy paste pottery sherds, nutshell, burned clay, and fire-cracked rocks.

Table 13. Distribution of prehistoric artifacts from the Last Chance Quarry site.

\begin{tabular}{lccccccc}
\hline \multicolumn{1}{c}{ Provenience } & PLAIN Sherd & $\begin{array}{c}\text { DeCORATEd } \\
\text { Sherd }\end{array}$ & ToOl & LD & FCR & BC & NS \\
\hline Surface & - & - & 1 & 3 & - & - & - \\
ST 78 & - & - & - & 7 & - & - & - \\
ST 79 & 2 & - & - & 5 & - & - & 1 \\
ST 83 & - & - & - & 1 & - & - & - \\
ST 87 & - & - & - & 1 & - & - & - \\
ST 90 & 1 & - & - & 1 & - & - & - \\
ST 93 & 1 & - & - & - & - & - & - \\
ST 95 & - & 1 & - & - & - & - & - \\
ST 99 & - & - & - & 1 & - & - & - \\
ST 100 & - & - & - & 10 & - & - & - \\
ST 101 & - & - & - & 1 & 1 & - & - \\
Unit 341 & 1 & - & - & 21 & - & 1 & - \\
\hline Totals & 5 & 1 & 1 & 51 & 1 & 1 & 1 \\
\hline
\end{tabular}

$\mathrm{LD}=$ lithic debris; FCR = fire-cracked rock; $\mathrm{BC}=$ burned clay; NS = nutshell

We were unable to document evidence of the use of the Last Chance Quarry site as a prehistoric quarry. While it is the case that there are siliceous stone gravels eroding out of the pipeline cut, as well as large sandstone rocks, no quarry pits or concentrations of lithic knapping debris were noted on the site. The siliceous stones, probably quartzite, petrified wood, and chert raw materials, are small and pebble-sized, and appear to be too small to have been readily worked as ought to be expected at a quarry location. We interpret these exposed siliceous stones as a natural gravel deposit on the slope of the landform.

The density of artifacts at the Last Chance Quarry site, including nutshell $(n=1)$ and fire-cracked rock ( $\mathrm{n}=1,0.1 \mathrm{~kg}$ ), in the shovel tests is 3.9 per positive shovel test or 31.2 artifacts per $\mathrm{m}^{2}$. The shovel tests with the highest artifact densities are ST 78, ST 79, and ST 100 in midden deposits in the central part of the site (see Figure 55). In Unit 341 , the artifact density is 92.0 per $\mathrm{m}^{2}$. Prehistoric artifacts are concentrated at 0-30 $\mathrm{cm}$ bs in this excavation unit.

Among the prehistoric lithic artifacts found at the Last Chance Quarry site in the 2010 archaeological investigations is a brownish-gray chert bifacial tool fragment (Figure 56) found on the surface at the southern end of the site (see Figure 55). It is $4.4 \mathrm{~mm}$ thick and has been fractured longitudinally across the blade.

The lithic debris recovered from the site is derived from the prehistoric use of a combination of locally and non-locally obtained lithic raw materials (see Gadus et al. 2002:42-43 and Table 2), particularly quartzite and petrified wood. These include locally available quartzite $(n=13 / 69 \%$ cortical) and petrified wood ( $n=7 / 43 \%$ cortical), red chert $(n=2 / 100 \%$ cortical), yellow chert $(n=1 / 0 \%$ cortical), brown chert ( $n$ 
$=1 / 0 \%$ cortical), brownish-yellow chert $(n=1 / 100 \%$ cortical), grayish-brown ( $n=5 / 0 \%$ cortical), as well as probable non-local (Central Texas) raw materials: light gray ( $n=1 / 0 \%$ cortical), dark gray ( $n=4 / 0 \%$ cortical), bluish-gray chert ( $n=1 / 100 \%$ cortical), and dark brown chert with blue inclusions ( $n=1 / 0 \%$ cortical). Raw materials that have an indeterminate source include gray chert ( $n=4 / 0 \%$ cortical). The initial reduction of local raw materials, in the form of pebbles and cobbles of siliceous materials, was more often done at the Last Chance Quarry sites that was the resharpening and refurbishing of tools or nearly completed tools that had been made from non-local raw material sources and brought to the site for use.

Six aboriginal ceramic sherds were found in

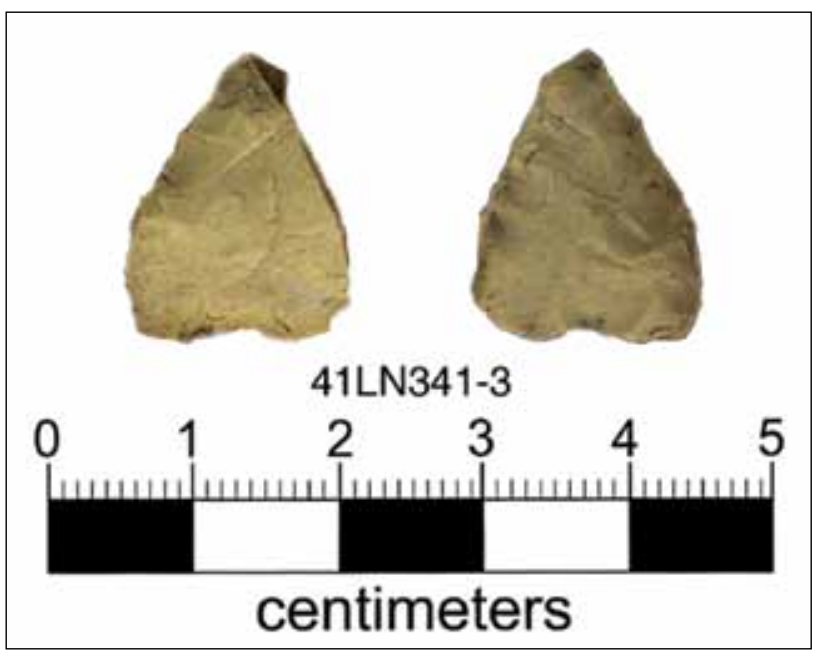

Figure 56. Bifacial tool fragment from the Last Chance Quarry site, found on the surface. the 2010 work in the prehistoric archaeological deposits at the Last Chance Quarry site (Table 14). These are concentrated in the central and northern parts of the site (see Figure 55), with several sherds coming from the midden deposits. As with Corbin et al.'s (1994) findings, plain sandy paste Goose Creek Plain, var. unspecified sherds are by far the most abundant pottery ware at the site, and these occur in three shovel tests (either in or north of the midden deposits) and Unit 341 at 0-30 cm bs as well as $60-80 \mathrm{~cm}$ bs; the discontinuity in depth suggests there may have been two periods of manufacture and use of sandy paste pottery at the site during the accumulation of the midden deposits. The shallower sandy paste sherds may be directly associated with the decorated grog tempered sherd from $11 \mathrm{~cm}$ bs (Table 14), it dating after ca. A.D. 1200, and thus may be younger in age than the more deeply buried and possibly Woodland period plain sandy paste sherds.

Table 14. Plain and decorated ceramic sherds from the Last Chance Quarry site.

\begin{tabular}{lcccc}
\hline PROVENIENCE (CM BS) & SHERD TYPe & TEMPER & PASTE & DECORATION \\
\hline ST 79, 0-20 & body & - & sandy & plain \\
ST 79, 60-75 & body & - & sandy & plain \\
ST 90,60-80 & body & - & sandy & plain \\
ST 93, 0-20 & body & - & sandy & plain \\
ST 95, 11 & body & grog & clayey-silty & parallel brushed \\
Unit 341, 20-30 & rim & - & sandy & plain \\
\hline
\end{tabular}

These sandy paste sherds include a plain rim sherd with a direct profile and a rounded lip (Figure 57a), and four plain body sherds. All of them have been smoothed on either one or both sherd surfaces, and are relatively thin walled: $5.7 \mathrm{~mm}$ for the one rim and a mean of $7.33 \pm 0.68 \mathrm{~mm}$ for the body sherds. With respect to vessel firing, $60 \%$ of the sandy paste sherds are from vessels fired in a reducing environment and cooled in the open air; $20 \%$ are from an incompletely oxidized vessel; and $20 \%$ are from a sherd with a distinctive core with a dark exterior/light exterior cross-section or a lighter core than its surface (see Appendix 4). Aten and Bollich (2002:54-55) note that this manner of vessel firing is characteristic of Goose 
Creek Plain, var. unspecified. They also suggest that vessels with this kind of firing may have been placed in a fire with the "orifice [of the vessel] facing into the fire." Furthermore, the sherds with cores lighter than the surfaces may have come from vessels where "after extended firing that burned off all organics, the fire may have been smothered to cause reduction and darkening of the exterior surface."

The one grog-tempered sherd is from a utility ware jar incompletely oxidized during firing. It has moderately thick vessel walls $(7.4 \mathrm{~mm})$ and has been smoothed on the interior of the vessel, as are most utility ware vessels. The sherd has parallel brushing marks on its exterior surface (see Figure 57b), which

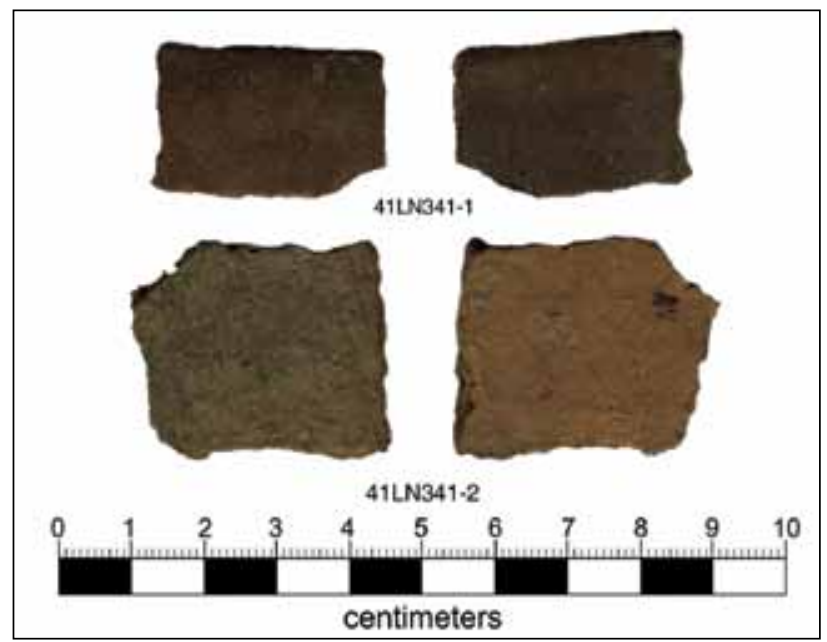

Figure 57. Plain and decorated sherds: a, plain sandy paste rim; $b$, brushed body sherd. is a common decorative method on East Texas Caddo pottery made after ca. A.D. 1200. It is suspected that this sherd came from a vessel manufactured by Caddo peoples in the East Texas region, but this has not been confirmed by either petrographic or instrumental neutron activation analysis.

\section{$41 L N 342$}

This small (20 $\mathrm{m}$ in diameter) prehistoric site of unknown age was located during the initial 1992 survey work at Fort Boggy State Park on an upland ridge slope (340 feet amsl) southeast of the Boggy Creek floodplain (Corbin et al. 1994:98). Nine shovel tests recovered lithic debris $(n=5)$ and fire-cracked between 27 and $95 \mathrm{~cm}$ bs (Corbin et al. 1994:98 and Table 7).

Extensive shovel testing $(n=17)$ in 2010 led to the relocation of 41 LN342 in a partially wooded upland slope, adjacent to a pipeline right-of-way and road (Figure 58). The wooded part of the landform had a thick understory of yaupon holly and mustang grapevines. Open areas on the landform have a ground cover of tall grasses and bull nettles. Surface visibility was less than $10 \%$.

In investigations in 2010 at $41 \mathrm{LN} 342$, a moderate density of prehistoric artifacts of unknown age has been recovered from two of the 17 excavated shovel tests and Unit 342, the 50 x $50 \mathrm{~cm}$ unit (see Figure 58). The estimated site size, given the non-contiguous nature of the subsurface archaeological deposits (see Figure 58), is $20 \times 20 \mathrm{~m}$ (0.1 acres). These artifacts are from depths of $0-80 \mathrm{~cm}$ bs in Hearne fine sandy loam sediments in the shovel tests, and $50-70 \mathrm{~cm}$ bs in Unit 342, suggesting the deposits in some parts of the site are shallowly buried.

Small pieces of fire-cracked rock are relatively common at the site $(n=8,0.60 \mathrm{~kg})$, suggesting some hot rock cooking activities took place here in the past. Also present are pieces of lithic debris and cores (n = 5) and charred nutshells $(n=2)$ from $50-60 \mathrm{~cm}$ bs in Unit 342 . The density of prehistoric artifacts is 5.0 per positive shovel test (ca. 40.0 artifacts per m), but only 20.0 artifacts per $\mathrm{m}^{2}$ in Unit 342 , including the charred nutshells. The lithic debris are from several different raw materials, including heat-treated quartzite ( $n=2 / 50 \%$ cortical), gray chert $(n=1 / 0 \%$ cortical), and grayish-brown chert $(n=1 / 0 \%$ cortical). The one core (Unit $342,60-70 \mathrm{~cm}$ ) is a multi-platform cortex-covered flake core of reddish-brown chert (17.8 $\mathrm{mm}$ in 
FIGURE 58. REDACTED

Figure 58. Map of $41 \mathrm{LN} 342$.

length, $43.0 \mathrm{~mm}$ in width, and $18.0 \mathrm{~mm}$ in thickness). The lithic pieces with cortex, including the one core, were struck off of stream-rolled gravel sources. 
In addition to the prehistoric artifacts from $41 \mathrm{LN} 342$, a single body/base sherd of plain ironstone (post1850) was found on the surface near ST 115 (see Figure 58).

\section{LN343, Fern Slope Site}

4lLN343 was reported by Corbin et al. (1994:98) as a small (30 $\mathrm{m}$ in diameter) prehistoric site of unknown age on an upland slope ( 280 feet amsl) ca. $6 \mathrm{~m}$ above the Boggy Creek floodplain and the floodplain of a northward-flowing intermittent tributary to Boggy Creek. A small amount of non-diagnostic lithic debris (n = 7) was recovered between 84 and $190 \mathrm{~cm}$ bs in 11 shovel tests excavated during the initial site recording work (Corbin et al. 1994:98 and Table 7).

The Fern Slope site was relocated in 2010 through intensive shovel testing of the upland slope landform adjacent to the floodplains of Boggy Creek and one of its tributaries (Figure 59). The landform has an overstory of hardwoods, and an understory of yaupon holly, american beauty bushes, mustang grapevines, and green brier. Surface visibility is less than $10 \%$.

During the 2010 archaeological investigations, six of the 16 shovel tests excavated across the landform and in Unit 343 were found to contain prehistoric archaeological deposits (see Figure 59). The size covers an estimated $2000 \mathrm{~m}^{2}$ ( 0.5 acres). These deposits ranged from 40 to $100 \mathrm{~cm}+\mathrm{bs}$ in Padina loamy fine sandy sediments, with the deepest deposits in the central and northern part of the Fern Slope site (i.e., ST 876, 888, and 889, as well as Unit 343. The density of artifacts, including animal bone ( $n=3$, see Appendix 5), nutshell ( $n=51$, including both hickory and black walnut) and hickory and oak wood charcoal $(n=14)$ (see Appendix 6), is 7.0 per positive shovel test or 56.0 artifacts per $\mathrm{m}^{2}$. In Unit 343 , the artifact density is a robust 272.0 per $\mathrm{m}^{2}$. By depth, the highest densities of artifacts occur at $30-60 \mathrm{~cm}$ bs.

The prehistoric artifacts from the site include one ceramic body sherd and lithic debris, the evidence of chipped stone tool manufacture and maintenance that took place here in the past. The ceramic sherd (ST $877,20-40 \mathrm{~cm} \mathrm{bs}$ ) is a plain body sherd (6.6 mm in thickness) with a sandy paste and grog-temper. The sherd is from a vessel that has been smoothed on both interior and exterior surfaces, and was fired in a reducing environment. The vessel apparently was pulled from the fire and cooled in the open air, leaving a thin oxidized band on the exterior surface of the sherd (see Teltser 1993:Figure 2g). The grog temper and sandy paste combination for a ceramic vessel in this part of Texas suggests the vessel was made after ca. A.D. 900-1000 (see Ricklis 2004).

A variety of lithic raw materials are represented in the lithic debris from the Fern Slope site. This includes petrified wood ( $n=7 / 28.6 \%$ cortical), chalcedony ( $n=1 / 0 \%$ cortical), and quartzite $(n=3 / 33 \%$ cortical), as well as several different colors of chert: brown ( $n=3 / 66.7 \%$ cortical), reddish-brown $(n=1 / 0 \%$ cortical), red ( $n=2 / 50 \%$ cortical), gray $(n=10 / 20 \%$ cortical); light gray $(n=3 / 0 \%$ cortical), dark gray $(n=$ $2 / 50 \%$ cortical), dark gray to black ( $n=1 / 0 \%$ cortical), and dark brown ( $n=1 / 100 \%$ cortical). The common occurrence of cortical flakes in most of the lithic raw material classes indicates that the initial reduction of locally available pebbles and cobbles was a common knapping activity at the site, presumably one stage in the eventual manufacture of tools from cores and flakes. 
FIGURE 59. REDACTED

Figure 59. Map of the Fern Slope site. 


\section{LN344, Highway Hill Site}

This prehistoric site of unknown age was situated on an upland slope landform (320 feet amsl) overlooking the Boggy Creek floodplain to the northeast as well as the floodplain of an unnamed tributary to Boggy Creek; site size was estimated at $20 \mathrm{~m}$ in diameter (Corbin et al. 1994:98). A small amount of chert lithic debris $(n=4)$ and a quartzite scraper were recovered between 12 and $30 \mathrm{~cm}$ bs in nine shovel tests (Corbin et al. 1994:98 and Table 7); the occurrence of charred nutshells was mentioned on the site form.

The Highway Hill was relocated in 2010 on a rather steep upland slope that is situated a short distance east from the I-45 right-of-way (Figure 60). Weches Formation sandstone outcrops along the slope. The

FIGURE 60. REDACTED

Figure 60. Map of the Highway Hill site. 
overstory consists of hardwoods, and the thick understory is consist with that at other Fort Boggy State Park sites: yaupon holly, mustang grapevines, green brier, and bull nettles. Surface visibility was mess than $10 \%$.

Seven of the 16 excavated shovel tests and Unit 344 at the Highway Hill site have prehistoric archaeological deposits of unknown age that range from $0 \mathrm{~cm}$ bs to $100 \mathrm{~cm}$ bs in Padina fine sandy loam sediments (see Figure 60). The site area covers ca. $3000 \mathrm{~m}^{2}$ (0.74 acres), quite a bit larger than the site estimate offered after the initial site recording effort in 1992. The deepest deposits are in ST 858, ST 864, ST 868 , and ST 873 and Unit 344 . The artifact density in the shovel testing is 1.57 artifacts per positive shovel test or 12.6 artifacts per $\mathrm{m}^{2}$. In Unit 344 , the artifact density is 40 per $\mathrm{m}^{2}$, including the nutshell $(\mathrm{n}=1)$ and wood charcoal pieces $(n=6)$. SAT 858 and ST 859 also have nutshell and wood charcoal fragments.

The prehistoric artifacts from 4 lLN344 include only pieces of lithic debris $(n=12)$. These are on petrified wood ( $n=3 / 33 \%$ cortical), quartzite ( $n=3 / 0 \%$ cortical), gray chert ( $n=3 / 0 \%$ cortical), light gray chert ( $n=1 / 0 \%$ cortical), dark gray chert $(n=1 / 0 \%$ cortical), and dark grayish-brown chert $(n=1 / 100 \%$ cortical).

\section{$41 L N 346$}

$41 \mathrm{LN} 346$ was recorded as a prehistoric site of unknown age situated on an upland toe slope (280 feet amsl) overlooking the Boggy Creek floodplain. The size of the site was estimated at $20 \mathrm{~m}$ in diameter (Corbin et al. 1994:99).

Lithic debris, a pitted stone, and a large biface were found either on the surface, eroding out of a stream cut bank, or were recovered in the nine shovel tests excavated at the site at that time (Corbin et al. 1994:Table 7). The bifacial tool was a large (139 $\mathrm{mm}$ in length) brown chert biface with extensive reworking of the lateral edge. Corbin et al. (1994:118 and Figure 31) suggest this bifacially-chipped tool was made during the Late Archaic, but provide no evidence or reasoning to substantiate this. Given the other artifacts found at $41 \mathrm{LN} 341$, as well as those recovered in the 2010 relocation work, the age of this biface is more reasonably interpreted as currently unknown.

The 2010 archaeological investigations at Fort Boggy State Park determined that 41 LN346 was situated on a hardwood-covered toe slope near an erosional gully/spring and small stretch of floodplain (Figure 61). The landform also had a thick understory of yaupon holly, american beauty bushes, mustang grapevines, and green brier. Surface visibility was less than $10 \%$.

Prehistoric lithic artifacts of unknown age were recovered at $20-40 \mathrm{~cm}$ bs and $90-100 \mathrm{~cm}$ bs in Hearne fine sandy loam sediments in one of 13 shovel tests excavated across the landform, as well as in Unit 346 at the site (see Figure 61). The estimated extent of $41 \mathrm{LN} 346$ is $15 \times 15 \mathrm{~m}$. The depth of the artifacts in Unit 346 (90-100 cm bs) suggests there are buried archaeological deposits at the site. The density of artifacts in the shovel tests is a low 1.0 per positive shovel test or 8.0 artifacts per $\mathrm{m}^{2}$. Including the one piece of wood charcoal, the artifact density in Unit 346 is still a low 12.0 per $\mathrm{m}^{2}$.

The chipped stone artifacts from the site consist of a few pieces of lithic debris, all non-cortical. Raw materials represented are brown chert $(n=1)$, heat-treated quartzite $(n=1)$, and gray chert $(n=1)$.

\section{$41 L N 347$}

This site was recorded as a prehistoric site of unknown age, located on an upland landform (345 feet amsl) 
FIGURE 61. REDACTED

Figure 61. Map of 41LN346.

and estimated at only about $20 \mathrm{~m}$ in diameter (Corbin et al. 1994:99). Shovel testing $(\mathrm{n}=6)$ here recovered the tip of a chert bifacial preform (Corbin et al. 1994:111) and five pieces of lithic debris from 60-70 cm bs.

Extensive shovel testing $(n=11)$ in 2010 relocated $41 \mathrm{LN} 347$ on the upland landform pinpointed by Corbin et al. (1994) (Figure 62). Part of the landform had a hardwood overstory with yaupon holly and 
FIGURE 62, REDACTED

Figure 62. Map of $41 \mathrm{LN} 347$.

mustang grapevines, with the remainder mainly open areas with small hardwoods and a ground cover of grasses and bull nettles. Surface visibility was less than $10 \%$.

Additional work at $41 \mathrm{LN} 347$ during the 2010 archaeological investigations recovered temporally nondiagnostic prehistoric chipped and ground stone artifacts from 0-100 cm bs in Hearne fine sandy loam 
sediments in three shovel tests and Unit 347 (see Figure 62). Site size is estimated at $1000 \mathrm{~m}^{2}(0.25$ acres), a good bit larger than determined during the initial site recording effort by Corbin et al. (1994). The density of prehistoric artifacts in the shovel tests is only 1.33 per positive shovel test or 10.64 artifacts per $\mathrm{m}^{2}$. In Unit 347 , the density of prehistoric artifacts is 32.0 per $\mathrm{m}^{2}$. A cut nail (1820-1891) in Unit 347 (20-30 cm bs) indicates a very limited use of the site in the nineteenth century.

A ferruginous sandstone mano was recovered in Unit 347 at $70-80 \mathrm{~cm}$ bs. The mano had a smoothed grinding surface that was created by the regular grinding of seeds and other plant materials across the surface on a metate or grinding slab. Other prehistoric artifacts from $41 \mathrm{LN} 347$ include lithic debris: petrified wood ( $n=3 / 0 \%$ cortical), light gray chert ( $n=1 / 0 \%$ cortical), gray chert ( $n=5 / 0 \%$ cortical), and dark grayish-brown chert ( $n=2 / 0 \%$ cortical). The absence of cortical flakes suggests that the prehistoric knapping of chipped stone of the site was primarily focused on the maintenance and resharpening of completed tools brought too and presumably used at $41 \mathrm{LN} 347$.

\section{$41 L N 348$}

4 lLN348 was described by Corbin et al. (1994:100) as a prehistoric site of unknown age that was located on the eastern edge of an upland landform (340 feet amsl) south of the Boggy Creek floodplain; a small intermittent tributary to Boggy Creek flows by the site. Site size was estimated at the time as $20 \mathrm{~m}$ in diameter. Supposedly eight shovel tests recovered a small amount of lithic debris $(n=7)$ from $15-90 \mathrm{~cm}$ bs (Corbin et al. 1994:100 and Tables 6 and 7), but the number of positive shovel tests does not accord with what was apparently actually recovered in that work.

The 2010 work at 4 lLN348 determined through extensive shovel testing $(n=17)$ that the site covers a small area of the upland landform (Figure 63). The landform has a hardwood overstory and a thick understory of yaupon holly and mustang grapevines. Surface visibility is less than $10 \%$.

During the 2010 work at the site, only two shovel tests and Unit 348 had prehistoric archaeological deposits of unknown age (see Figure 63). These deposits ranged from $20 \mathrm{~cm}$ bs to $90 \mathrm{~cm}$ bs in Hearne fine sandy loam sediments. Site size is estimated at only $20 \times 20 \mathrm{~m}(0.1$ acres). The density of prehistoric artifacts in the shovel tests is 2.0 per positive shovel test or 16.0 artifacts per $\mathrm{m}^{2}$. In Unit 348 , including nutshell $(n=6)$ and wood charcoal $(n=1)$, the artifact density is 40.0 per $\mathrm{m}^{2}$.

The prehistoric artifacts at 4 lLN348 are pieces of lithic debris. They are from the following knapped and locally available raw materials: quartzite $(n=5 / 0 \%$ cortical, including one piece of a coarse texture and gray color that resembles Garrison quartzite found in the Neches River basin in East Texas, see Perttula and Nelson [2006]) and petrified wood ( $n=3 / 66.7 \%$ cortical).

\section{$41 L N 349$}

This site was also located on an upland landform (340 feet amsl) on the south side of the Boggy Creek valley, and near an intermittent tributary that flows north towards Boggy Creek. The size of this prehistoric site of unknown age was estimated at $20 \mathrm{~m}$ in diameter (Corbin et al. 1994:100) at the time of its initial recording. Shovel testing $(n=14)$ at $41 \mathrm{LN} 349$ recovered lithic debris and fire-cracked rock at $70-90 \mathrm{~cm}$ bs (Corbin et al. 1994:100 and Table 7). 
FIGURE 63. REDACTED

Figure 63. Map of $41 \mathrm{LN} 348$.

Extensive shovel testing $(n=20)$ in the 2010 relocation effort at Fort Boggy State Park determined that 4 lLN349 was on an upland landform about $100 \mathrm{~m}$ west of a tributary to Boggy Creek (Figure 64). The landform had a hardwood overstory with a thick understory of yaupon holly and mustang grapevines. Surface visibility was less than $10 \%$.

In the 2010 work, only two shovel tests and Unit 349 at $41 \mathrm{LN} 349$ had prehistoric archaeological deposits (see Figure 64). Archaeological deposits apparently range from $20 \mathrm{~cm}$ bs to $60 \mathrm{~cm}$ bs in Hearne fine sandy 
FIGURE 64. REDACTED

Figure 64. Map of 41 LN349. 
loam sediments. Site size is estimated at $30 \times 30 \mathrm{~m}$ ( 0.2 acres). The density of artifacts in the shovel testing is 2.0 per positive shovel test or 16.0 artifacts per $\mathrm{m}^{2}$. In Unit 348 , including wood charcoal $(\mathrm{n}=3)$, the artifact density is 20.0 per $\mathrm{m}^{2}$.

A Late Archaic parallel-stemmed and flatbased dart point fragment was found at $30 \mathrm{~cm}$ bs in ST 39 (Figure 65). The point is made from a gray chert (which may be from a local gravel source), and is $5.4 \mathrm{~mm}$ thick on the stem; the stem width is $17.3 \mathrm{~mm}$. The other recovered prehistoric artifacts are lithic debris from the following raw materials: petrified wood ( $\mathrm{n}=1 / 0 \%$ cortical), quartzite $(\mathrm{n}=1 / 100 \%$ cortical), brownish-gray chert ( $n=2 / 100 \%$ cortical, including one flake with a roughened cortex, suggesting it had been obtained from a bedrock source), and a light gray chert $(n=$ $1 / 0 \%$ cortical).

\section{$41 L N 350$}
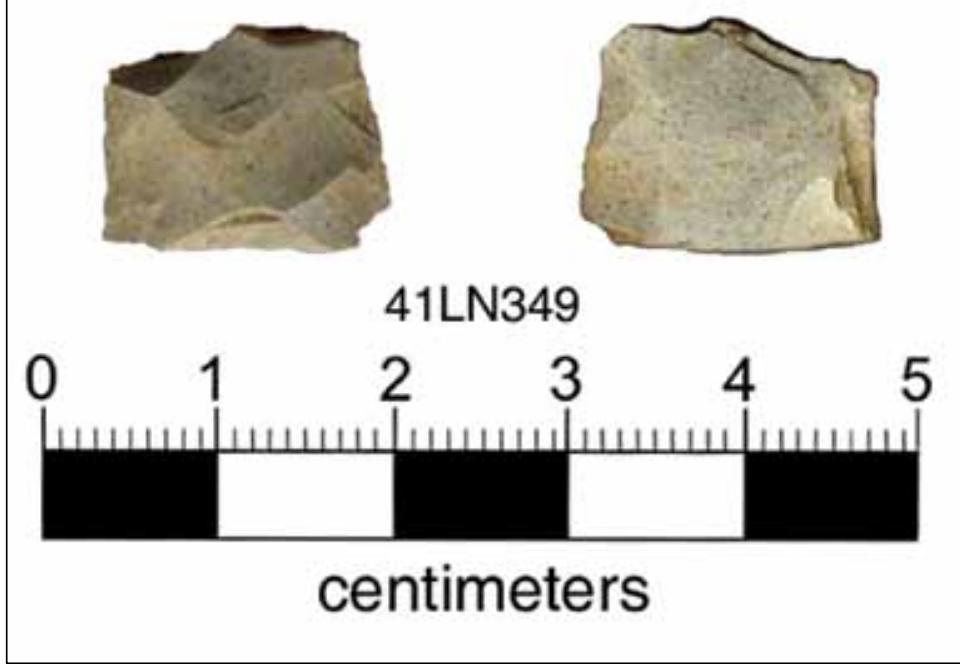

Figure 65. Late Archaic dart point from 41 LN349.

Corbin et al. (1994) reported that 4 lLN350 was a prehistoric site of unknown age located on an upland ridge slope (320 feet amsl). It was estimated to be $30 \mathrm{~m}$ in diameter. Shovel testing $(n=16)$ at the site recovered a small amount of lithic debris $(n=5)$ at $30-80 \mathrm{~cm}$ bs (Corbin et al. 1994:101 and Table 7).

Corbin (1996:2) later suggested that 4 lLN350 "contains archeological materials deep within a sand formation which matches the description of the Big Brushy." The Big Brushy Formation has been identified as a possible middle Holocene colluvial deposit that may contain deeply buried archaeological materials.

41 LN350 was relocated after extensive shovel testing in the 2010 archaeological investigations on an upland ridge slope. The landform has been bisected by an above-ground power line right-of-way as well as an underground AT \& T phone/fiber optic cable (Figure 66). The landform had a hardwood overstory with a thick understory of mustang grapevines and yaupon holly. The powerline right-of-way is open, with a ground cover of bull nettles and grasses. Surface visibility is less than $10 \%$.

Only a single shovel test and $50 \times 50 \mathrm{~cm}$ unit (Unit 350) in the 2010 work contained prehistoric archaeological deposits (see Figure 66); site size is $20 \times 20 \mathrm{~m}$ (0.1 acres). These archaeological deposits occurred at 0-20 cm bs in ST 5 and at 60-90 cm in Unit 350, in Hearne fine sandy loam sediments. The depth of artifacts from the site in the 2010 work does not support the assertions of Corbin (1996) that $41 \mathrm{LN} 350$ contains deeply buried prehistoric artifacts in a Big Brushy Formation. The density of artifacts in the shovel testing is a low 1.0 per positive shovel, or 8.0 artifacts per $\mathrm{m}^{2}$. In Unit 350 the artifact density is only 12.0 per $\mathrm{m}^{2}$.

Recovered artifacts from $41 \mathrm{LN} 350$ consist of prehistoric lithic debris $(n=4)$ of unknown age. All the lithic debris is from a locally available quartzite, $75 \%$ of which was heat-treated to increase its knappability, and $25 \%$ of which were cortical. 
FIGURE 66. REDACTED

Figure 66. Map of 41LN350. 


\section{$41 L N 351$}

Corbin et al. (1994:101) reported that $41 \mathrm{LN} 351$ was located on a lower toe slope (270 feet amsl) overlooking the Boggy Creek floodplain, and that there was an intermittent tributary to Boggy Creek $50 \mathrm{~m}$ east of the site. The site was estimated at that time as being $20 \mathrm{~m}$ in diameter. Shovel testing $(\mathrm{n}=20)$ recovered one plain Woodland period sandy paste body sherd (Goose Creek Plain, var. unspecified) and lithic debris $(\mathrm{n}=$ 2) from 50-100 cm bs (Corbin et al. 1994:101 and Tables 3 and 7).

Extensive shovel testing relocated 4 LLN351 along the northeastern part of a lower toe slope landform (Figure 67). The landform had an overstory of hardwoods with a thick understory of yaupon holly, mustang grapevines, and green brier. Surface visibility was less than $10 \%$.

Only two of the 18 shovel tests excavated at $41 \mathrm{LN} 351$ and Unit 351 in the 2010 work contained prehistoric archaeological deposits, but of unknown age (see Figure 67). Site size is estimated at $20 \times 20 \mathrm{~m}$ (0.1 acres). These archaeological deposits in Hearne fine sandy loam sediments range from $0 \mathrm{~cm}$ bs to 92 $\mathrm{cm}$ bs in thickness; in Unit 351, the prehistoric artifacts are found only between 80 and $92 \mathrm{~cm}$ bs, suggesting there are buried archaeological deposits on the site. The density of prehistoric artifacts in the shovel tests, including wood charcoal $(\mathrm{n}=3)$ in ST $18\left(60-80 \mathrm{~cm}\right.$ bs), is 3.5 per positive shovel test or 28.0 per $\mathrm{m}^{2}$. The prehistoric artifact density in Unit 351 is only 8.0 per $\mathrm{m}^{2}$. A single modern iron fence staple was recovered from 0-10 cm bs in Unit 351.

No temporally diagnostic artifacts were recovered at the site in the 2010 work. An ovoid petrified wood biface fragment was found in Unit 1 at $80-90 \mathrm{~cm}$ bs. The piece, which has a rough cortex and knot of material on one face, has seen little shaping or pressure flaking and is thick $(10.5 \mathrm{~mm})$. It can be classified as an early or Stage 1 biface (see Goode 2002:36-37). The other prehistoric artifacts are lithic debris $(n=5)$. These pieces of chipped stone knapping debris are on petrified wood $(n=1 / 100 \%$ cortical), quartzite ( $n=3 / 33 \%$ cortical), and grayish-brown chert ( $n=1 / 0 \%$ cortical).

\section{$41 L N 357$}

This site was described by Corbin et al. (1994:101) as a small (20 $\mathrm{m}$ in diameter) prehistoric site of unknown age on the north-facing slope (280 feet amsl) of the large alluvial terrace north of Boggy Creek. An intermittent stream was $20 \mathrm{~m}$ north of the site. Shovel testing $(n=16)$ done at that time recovered a very limited amount of lithic debris $(n=3)$ from depths of 38-70 cm bs (Corbin et al. 1994:101 and Table 7).

In the 2010 relocation effort at Fort Boggy State Park, extensive shovel testing along the eroded slope of the alluvial terrace landform north of Boggy Creek (Figure 68), was needed to identify areas with prehistoric archaeological deposits at $41 \mathrm{LN} 357$. The landform had a hardwood overstory and a thick understory of yaupon holly and mustang grapevines; bull nettles also constituted part of the ground cover. Surface visibility at the site was less than $10 \%$.

Two of the 20 shovel tests excavated at 4lLN357, and Unit 357, excavated in the 2010 work contained prehistoric archaeological deposits that ranged from $20 \mathrm{~cm}$ bs to $80 \mathrm{~cm}$ bs (see Figure 68) in Hearne fine sandy loam sediments. The estimated site size is $20 \times 20 \mathrm{~m}$ (0.1 acres). These archaeological deposits are marked by prehistoric lithic debris, which occur at low densities of 2.0 per positive shovel test or 16 artifacts 
FIGURE 67. REDACTED

Figure 67. Map of $41 \mathrm{LN} 351$.

per $\mathrm{m}^{2}$. In Unit 357, the prehistoric artifact density is only 4 per $\mathrm{m}^{2}$. One shovel test (ST 514) also had a wire nail (post-1891) that was recovered at $60-80 \mathrm{~cm}$ bs; this is a testament to considerable bioturbation and artifact movement in the fine sandy loam sediments over the last 100 years at the site.

The lithic artifacts from $41 \mathrm{LN} 357$ includes one cortex-covered petrified wood chunk and four pieces of lithic debris. They are from light gray chert $(n=1 / 0 \%$ cortical), gray chert ( $n=2 / 0 \%$ cortical), and 
FIGURE 68. REDACTED

Figure 68. Map of 41LN357.

gray novaculite ( $\mathrm{n}=1 / 0 \%$ cortical). The novaculite lithic debris likely would have been removed from a completed tool, perhaps during refurbishing or resharpening, obtained in trade, because the nearest source areas for novaculite are several hundred miles to the northeast along the Red River (see Banks 1990). 


\section{$41 L N 363$}

41 LN363 was reported to be a small (20 $\mathrm{m}$ in diameter) prehistoric site of unknown age that was located on an upland slope (310 feet amsl) above the Boggy Creek floodplain. Four shovel tests excavated at the site during the initial site recording work recovered only three pieces of lithic debris between 40 and $100 \mathrm{~cm}$ bs (Corbin et al. 1994:102 and Table 7).

This site was relocated in 2010 during shovel testing $(n=14)$ along an upland slope. The area is traversed by an above-ground powerline as well as a buried phone line right-of-way (Figure 69), along a Park boundary. The I-45 service road right-of-way runs parallel to the site. The landform is a mixture of hardwoods and an understory of yaupon holly and mustang grapevines and cleared areas along the utility line right-of-ways with a ground cover of grasses and bull nettle. Surface visibility is $20-30 \%$ in the right-ofways, but less than $10 \%$ elsewhere at 41 LN363.

A single shovel test, out of the 14 excavated on the landform, and Unit 363 contained a low density of prehistoric chipped stone artifacts of unknown age (see Figure 69). Site size is estimated at $20 \times 20 \mathrm{~m}(0.1$ acres). The density of artifacts is 1.0 per positive shovel test or 8 artifacts per $\mathrm{m}^{2}$. In Unit 363 , the artifact density is 8.0 per $\mathrm{m}^{2}$. These artifacts were recovered between 30 and $47 \mathrm{~cm}$ bs in Padina fine sandy loam sediments, suggesting the prehistoric archaeological deposit is at most shallowly buried.

The prehistoric chipped stone artifacts from $41 \mathrm{LN} 363$ are lithic debris from two different raw materials: quartzite $(n=2 / 0 \%$ cortical) and grayish-brown chert ( $1 / 0 \%$ cortical).

\section{$41 L N 364$}

This prehistoric site of unknown age was located on a northward-facing upland slope (310 feet amsl) overlooking the Boggy Creek floodplain (Corbin et al. 1994:102). It was small (20 $\mathrm{m}$ in diameter) and had prehistoric lithic debris $(n=1)$ from $35 \mathrm{~cm}$ bs in one of the seven shovel tests excavated at $41 \mathrm{LN} 364$ at that time (Corbin et al. 1994:102 and Table 7).

41 LN364 was relocated along a park boundary fence during the shovel testing effort $(n=10)$ during the 2010 archaeological investigations at Fort Boggy State Park. There are right-of-ways for both an aboveground powerline and a buried phone line that traverse the site, certainly disturbing the archaeological deposits, and the service road for I-45 lies just outside the site boundaries (Figure 70). The right-of-way areas have a ground cover of grasses and bull nettles, while the remainder of the landform is wooded with an overstory of hardwoods and an understory of mustang grapevines and yaupon holly.

A single shovel test and Unit 364 contained a low density of prehistoric chipped stone artifacts of unknown age (see Figure 70). The estimated site size is $20 \times 20 \mathrm{~m}$ ( 0.1 acres). The density of artifacts is a very low 1.0 per positive shovel test or 8 artifacts per $\mathrm{m}^{2}$. In Unit 364, the artifact density is an even lower 4.0 per $\mathrm{m}^{2}$. These artifacts were recovered between 80 and $100 \mathrm{~cm}$ bs in Padina loamy fine sandy sediments, suggesting the prehistoric archaeological deposit at the site may be relatively deeply buried.

The prehistoric chipped stone artifacts from $41 \mathrm{LN} 364$ are lithic debris from two different raw materials: quartzite $(n=1 / 0 \%$ cortical) and yellow chert ( $1 / 0 \%$ cortical). 
FIGURE 69. REDACTED

Figure 69. Map of 41 LN363. 
FIGURE 70. REDACTED

Figure 70. Map of 41LN364. 


\section{Multi-component (Prehistoric and Historical) Sites}

\section{$41 L N 310$}

41 LN310 was reported by Corbin et al. (1994:103) as being situated on an upland toe slope (295-300 feet amsl) that projects into the Boggy Creek floodplain. There was an old road bed (41LN330) to the east of the east, and an intermittent tributary to Boggy Creek on the west. Site size was estimated at $100 \mathrm{~m}$ in diameter (2.5 acres), and the site had two areas ( $A$ and $B$ ). Area $A$, at the northern end of the site, had exclusively prehistoric lithic artifacts, while Area B on the southern part of the landform had both prehistoric and historical artifacts (the site form mentions metal artifacts in this area).

Extensive shovel testing $(n=36)$ done at the time of the initial site recording defined both prehistoric Woodland and early twentieth-century (house site) components at $41 \mathrm{LN} 310$, as well as perhaps an occupation at the Late Paleoindian-Early Archaic transition. This latter component may be represented by a basal fragment of a white chert biface (Corbin et al. 1994:Figure 30b) that closely resembles a ca. 10,000 year old San Patrice, var. St. Johns projectile point (Jennings 2008:Figure 1b). The Woodland period component is marked by a well-made chert Gary point (Corbin et al. 1994:Figure 29e). Of unknown temporal associations are lithic debris $(n=31)$ and cores $(n=2)$ (Corbin et al. 1994:Table 7). Shovel testing in Area A may have encountered a prehistoric feature, it being described on the site form as a "compacted clay lens area mottled with charcoal and measures $60 \mathrm{~cm} \mathrm{x} 80 \mathrm{~cm} 12 \mathrm{~cm}$ below the surface. Profile shows it to be approximately $7 \mathrm{~cm}$ thick and the B horizon another $40 \mathrm{~cm}$ below this."

The historical component at $41 \mathrm{LN} 310$ was first noted on an 1933 USDA aerial photograph as an area with a standing structure. During the initial site recording investigations, only a single piece of a plain whiteware sherd was found at the site (Corbin et al. 1994:Table 8).

In the 2010 site relocation effort, there are two areas ( $A$ and $B$ ) on an upland toe slope that were found to have prehistoric archaeological deposits (Figure 71). The area between has been disturbed by a park road, an old AT \& T phone line, and a more recent fiber optic cable. The eastern margin of the site is marked by an old and deep (3-4 m) road cut. Much of the southern part of the site has been severely eroded. The landform has hardwood trees with small groves of yaupon holly bushes; more open areas on the site have grasses, bushes, and bull nettles. Surface visibility ranges from $20 \%$ to $30 \%$ in eroded areas, and less than $10 \%$ elsewhere.

A total of 23 shovel tests were excavated across the landform at $41 \mathrm{LN} 310$ in the 2010 archaeological investigations at Fort Boggy State Park. The distribution of the positive shovel tests as well as surface artifacts indicate the maximum estimated extent of the site is $4900 \mathrm{~m}^{2}$ ( 1.2 acres).

During the 2010 archaeological investigations only four shovel tests and Unit 310 were found to contain prehistoric archaeological deposits in Wolfpen loamy fine sand sediments (see Figure 71). These deposits ranged from $0 \mathrm{~cm}$ bs to $100 \mathrm{~cm}$ bs, with the deepest deposits in ST 184, ST 185, and Unit 310 in Area B. In Unit 310 , the prehistoric deposits are shallowly and probably recently buried (i.e., 0-20 cm bs sediments do not contain artifacts). The artifact density in the shovel tests is 4.25 per positive shovel test or 34.0 artifacts per $\mathrm{m}^{2}$. In Unit 310, the artifact density is 72.0 per $\mathrm{m}^{2}$. No evidence of possible historical archaeological deposits reported by Corbin et al. (1994) were detected during the 2010 relocation work. 
FIGURE 71. REDACTED

Figure 71. Map of $41 \mathrm{LN} 310$. 
The artifacts from $41 \mathrm{LN} 310$ include a single arrow point, lithic debris, and wood charcoal $(n=2)$ from $80-100 \mathrm{~cm}$ bs in ST 184. The arrow point, made from a local petrified wood, is a Friley point with a short contracting stem, flat base, and a unifacial serrated blade (Figure 72). Such points may date from as early as ca. A.D. 700 (the latter part of the Woodland period) (Shafer and Walters 2010:145) to perhaps the early part of the Late Prehistoric period (a. A.D. 1000).

The lithic debris in the assemblage is composed of several raw materials, including locally available petrified wood ( $n=13 / 30.8 \%$ cortical), quartzite ( $n=$
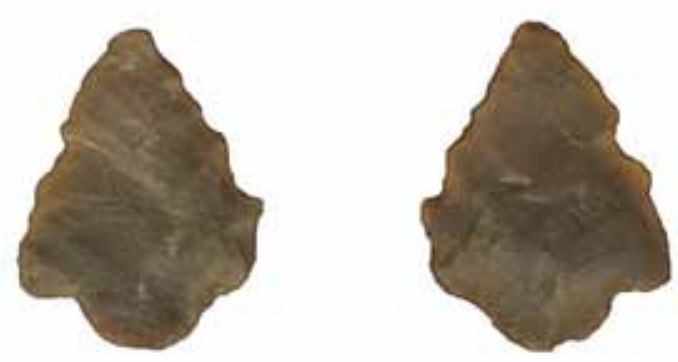

41LN310

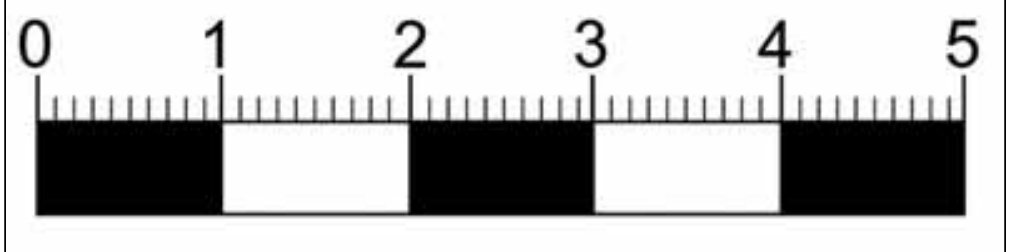

Figure 72. Friley arrow point from $41 \mathrm{LN} 310$, ST $185,40-60 \mathrm{~cm}$ bs. $10 / 30 \%$ cortical), and cherts likely obtained out of stream gravels in the Post Oak Savannah, including the Trinity River. The cherts are various colors: gray ( $n=3 / 0 \%$ cortical), light gray ( $n=2 / 0 \%$ cortical), dark gray ( $n=1 / 100 \%$ cortical), brown ( $n=1 / 100 \%$ cortical), brownish-gray ( $n=1 / 0 \%$ cortical), and brownishred chert ( $n=1 / 0 \%$ cortical). Given the proportions of cortical flakes among the pieces of lithic debris from 4lLN306, it is likely that the site was a locale where the initial decortification of pebbles and cobbles of locally available materials-including some cherts-was a major emphasis of lithic knapping to produce tools.

\section{LN312, Halfway House Site}

This site was located on an upland ridge slope (310 feet amsl) that projected south into the Boggy Creek floodplain. It was estimated to cover a $30 \mathrm{~m}$ diameter area (Corbin et al. 1994:103-104). Surface collections and one shovel test were completed at $41 \mathrm{LN} 312$ during the initial site recording.

The prehistoric component at the site was apparently represented by a single piece of lithic debris. The suspected mid-nineteenth-century-1930s historical house site component was marked by a rectangular structure pattern of large ferruginous sandstone rocks and brick, as well as a surface scatter of historical artifacts. These included a FERRIS (ca. 1901-1926) brick fragment, plain whiteware sherds (n=21), midnineteenth-century transfer-printed whiteware sherds ( $n=4$, cf. Samford 2000), late nineteenth-early twentieth-century repousse whiteware sherds $(n=5)$, stoneware $(n=1)$, porcelain $(n=4)$, bottle glass sherds $(n=2)$, and cut nails $(n=2)$.

The Halfway House site was relocated in 2010 through both pedestrian survey and shovel testing. A few historical artifacts were observed in a road cut (associated with an AT \&T phone line and fiber optic cable right-of-way, and shovel tests indicate that the site extended east to another older road cut (Figure 73). The site itself has several large oak trees and an understory of yaupon holly bushes and green brier; surface visibility outside the western road was less than $10 \%$. 
FIGURE 73. REDACTED

Figure 73. Map of the Halfway House site. 
There are a number of sandstone rocks in the central and southern part of the site, and these may represent piers to the historical rock foundation earlier noted by Corbin et al. (1994), although no obvious rectangular structure pattern is apparent anymore. The western road cut appears to have displaced or removed some of these rocks, because they cannot be relocated. Shovel tests ( $n=12)$, surface artifacts, and sandstone foundation rocks suggest that the Halfway House site covers a ca. $1600 \mathrm{~m}^{2}$ (0.4 acres) area, almost twice as large as area as was originally determined during the initial site recording work done in 1992 by Corbin et al. (1994).

During the 2010 work at the Halfway House site, five shovel tests and Unit 312 were excavated that contained historical archaeological deposits in Wolfpen loamy fine sand (see Figure 73). These deposits ranged from $10 \mathrm{~cm}$ bs to $20 \mathrm{~cm}$ bs in thickness. The density of historical artifacts in the shovel testing is 1.8 per positive shovel test, or 14.4 artifacts per $\mathrm{m}^{2}$. In Unit 312 , the artifact density is 32.0 per $\mathrm{m}^{2}$.

Both domestic and architectural items are represented in the historical artifacts. The domestic artifacts consisted of a sherd that is probably from a milk glass cosmetics container, tin can fragments ( $n$ $=11+$ ), bottle glass (green, $n=1$; clear, $n=1$ ), plain whiteware body and base sherds $(n=9)$, a porcelain decalcomania sherd (ca. 1880-1920 and later), and a piece of cast iron that may have been part of a cast iron stove. The architectural artifacts include wire nails $(n=1$, post-1891) and aqua-colored window glass $(n=5)$. The mean thickness of the window glass $(2.42 \mathrm{~mm})$ suggests the panes of glass used at the Halfway House site were manufactured ca. 1916.5 \pm 7 (see Moir 1987). Surface artifacts noted at the site include six whiteware sherds, sheet metal roofing fragments, preserved structural wood fragments, and a rusted bucket.

The only evidence of the prehistoric component at the site is a single prehistoric multi-platform petrified wood core recovered in Unit 312. This core had a rough cortex, as if it had been obtained from a bedrock source. It is $49.0 \mathrm{~mm}$ in length, $76.8 \mathrm{~mm}$ in width, and $40.8 \mathrm{~mm}$ in thickness.

\section{$41 L N 321$}

Corbin et al. (1994:104 and Figure 27) reported that 41LN321 was located on an alluvial terrace landform (270-290 feet amsl) that projected into the Boggy Creek floodplain, just north of an old channel of Boggy Creek. The site was estimated at that time to cover a $200 \times 80 \mathrm{~m}$ area (ca. 4.0 acres), as defined by artifacts on the surface and artifacts recovered from 96 shovel tests; 28 of the shovel tests were positive, and contained artifacts at depths of $0-120 \mathrm{~cm}$ bs. A 1 x $1 \mathrm{~m}$ unit was also apparently excavated in the northern part of the site, but no information was provided by Corbin et al. (1994) about what was found there.

The prehistoric archaeological component at $41 \mathrm{LN} 321$ apparently dated to the Woodland period, based on the recovery of two contracting stem Gary points (Corbin et al. 1994:114-115). Such dart points may have been made ca. 2500-1200 years B.P. (Turner and Hester 1999:123). Also marking this prehistoric component were a chert scraper, lithic debris $(n=105)$, and fire-cracked rock (Corbin et al. 1994:Table 7). Most of the prehistoric artifacts were recovered in what was referred to as Area $A$ at the southern end of the landform.

The historical component at the site apparently dated from the mid- to the late nineteenth century and was concentrated in Area B at the northern and higher part of the landform (Corbin et al. 1994:104-105 and Figure 27). An old road bed (4lLN332) bisects the site. This area had a raised clay platform for a structure; large rocks in this area may also be from a structure. A shallow depression to the north of the platform may be a filled-in well. historical artifacts from surface collections and shovel testing done at that time included 
mid-nineteenth-century brown transfer-printed whiteware sherds $(n=1)$, late nineteenth to early twentiethcentury decalcomania sherds, stoneware sherds, cut nails (1820-1891), iron kettle fragments, and farm equipment (Corbin et al. 1994:104-105 and Table 8).

In 2010, extensive shovel testing ( $n=49$ ) was conducted on an alluvial terrace landform to relocate 41 LN321 and better define its extent and archaeological character (Figure 14). During that work, both prehistoric and historical archaeological deposits and associated material remains were identified, but the historical raised clay platform, large rocks, or a possible filled-in well could not be relocated during our work; it is possible that the "clay platform" may simply have been an eroded section of the old road cut through the northern part of the site.

The landform at $41 \mathrm{LN} 321$ has an overstory of both large and small hardwoods with an understory of mustang grapevines. Surface visibility is less than $10 \%$ outside of the old road cut. The site is approximately $14,000 \mathrm{~m}^{2}$ in size (3.5 acres).

There are spatially extensive prehistoric archaeological deposits at $41 \mathrm{LN} 321$, based on the 23 positive shovel tests with prehistoric artifacts and Unit 321 findings (see Figure 74 and Table 15). Two shovel tests in the central part of the site (ST 542 and ST 572) also contained historical archaeological material remains. The prehistoric archaeological deposits range from $13 \mathrm{~cm}$ to $100 \mathrm{~cm}+$ in thickness in Hearne fine sandy loam sediments. Those shovel tests with the thickest prehistoric archaeological deposits $(>80 \mathrm{~cm})$ are distributed across all parts of the site, from the north (ST 546 and ST 556), central (ST 554 and ST 581), and southern (ST 550 and ST 576) areas. Outside of these locations, the prehistoric archaeological deposits range only between 13 and $60 \mathrm{~cm}$ bs, with a mean maximum depth of only $33 \mathrm{~cm}$ bs. The historical archaeological materials from the two shovel tests were found only between 0 and $20 \mathrm{~cm}$ bs.

The density of prehistoric artifacts in the shovel testing at $41 \mathrm{LN} 321$, including nutshell $(n=1)$, is 2.0 per positive shovel test or 16.0 artifacts per $\mathrm{m}^{2}$. In Unit 321 , the artifact density is also a low 16.0 artifacts per $\mathrm{m}^{2}$. The highest densities of prehistoric artifacts at the site include those recovered from ST 550 at the southern end of the landform (see Figure 74) and four shovel tests (ST 543,573,681, and 587) in the central part of the landform. Here, the range of prehistoric artifact densities is $24-40$ per $\mathrm{m}^{2}$. The density of historical artifacts at $41 \mathrm{LN} 321$ is 1.0 per positive shovel test or 8.0 artifacts per $\mathrm{m}^{2}$.

There are two chipped stone tools in the lithic assemblage from $41 \mathrm{LN} 321$ (see Table 15). The first is an expanding stem dart point stem fragment from ST 554 made from a dark gray chert (Figure 75). It has a convex base, no evidence of edge grinding, and may be from a broken Late Archaic Bulverde point. It has a stem width of $17.0 \mathrm{~mm}$, and is $5.1 \mathrm{~mm}$ thick. The other chipped stone tool (ST 545) is a cortical brown chert flake with evidence of unilateral use-wear/retouching. The use wear length on the flake tool is $7.1 \mathrm{~mm}$.

A ferruginous sandstone bi-pitted stone was recovered from ST $583(0-20 \mathrm{~cm}$ bs) near the northern end of the site. The pitted stone is $99.0 \mathrm{~mm}$ in length, $72.0 \mathrm{~mm}$ in width, and $39.9 \mathrm{~mm}$ in thickness. The two pits range from 17 to $23.0 \mathrm{~mm}$ in diameter.

The remaining prehistoric lithic artifacts are pieces of lithic debris from chipped stone tool manufacture. Several different kinds of lithic raw materials are present: quartzite ( $n=4 / 75 \%$ cortical), petrified wood ( $n$ $=1 / 0 \%$ cortical), yellow chalcedony $(n=1 / 0 \%$ cortical), red chert $(n=3 / 33 \%$ cortical), dark red chert $(n=$ $1 / 100 \%$ cortical), brownish-red chert ( $n=2 / 50 \%$ cortical), light brown chert ( $n=1 / 0 \%$ cortical), brown chert ( $n=2 / 0 \%$ cortical), light gray chert $(n=9 / 0 \%$ cortical), gray chert $(n=6 / 0 \%$ cortical), dark gray chert $(n=$ 
FIGURE 74. REDACTED

Figure 74. Map of 41LN321. 
$5 / 0 \%$ cortical), grayish-brown chert $(n=1 / 0 \%$ cortical), dark brown chert ( $n=2 / 0 \%$ cortical), dark brownblack chert ( $n=1 / 0 \%$ cortical), white chert ( $n=4 / 0 \%$ cortical), and honey-colored or "beeswax" Central Texas chert ( $n=1 / 100 \%$ cortical). Most of the different kinds and colors of lithic raw materials are represented by non-cortical flakes, suggesting they had been produced from the finishing or resharpening of nearly complete to complete tools brought to the use for use or refurbishing. Quartzite, red chert, dark red chert, and brownish-red chert lithic debris have high proportions of cortical flakes, indicating that these materials were likely brought to the site as pebbles or cobbles, then reduced for tool manufacture and/or the production of flakes for use as expedient flake tools.

Table 15. Distribution of prehistoric artifacts at $41 \mathrm{LN} 321$.

\begin{tabular}{|c|c|c|c|c|c|}
\hline Provenience & Dart PoInt & FLAKE TOOL & $\begin{array}{c}\text { Ground STONE } \\
\text { TOOL }\end{array}$ & LITHIC DEBRIS & NUTSHELL \\
\hline ST 539 & - & - & - & 1 & - \\
\hline ST 540 & - & - & - & 1 & - \\
\hline ST 542 & - & - & - & 2 & - \\
\hline ST 543 & - & - & - & 3 & - \\
\hline ST 544 & 1 & - & - & - & - \\
\hline ST 545 & - & 1 & - & - & - \\
\hline ST 546 & - & - & - & 2 & - \\
\hline ST 549 & - & - & - & 1 & - \\
\hline ST 550 & - & - & - & 3 & - \\
\hline ST 553 & - & - & - & 1 & - \\
\hline ST 554 & - & - & - & 2 & - \\
\hline ST 556 & - & - & - & 1 & - \\
\hline ST 558 & - & - & - & 2 & - \\
\hline ST 560 & - & - & - & 2 & - \\
\hline ST 572 & - & - & - & 1 & - \\
\hline ST 573 & - & - & - & 3 & - \\
\hline ST 575 & - & - & - & 2 & - \\
\hline ST 576 & - & - & - & - & 1 \\
\hline ST 580 & - & - & - & 2 & - \\
\hline ST 581 & - & - & - & 4 & - \\
\hline ST 583 & - & - & 1 & - & - \\
\hline ST 585 & - & - & - & 1 & - \\
\hline ST 586 & - & - & - & 1 & - \\
\hline ST 587 & - & - & - & 5 & - \\
\hline Unit 321 & - & & - & 4 & - \\
\hline Totals & 1 & 1 & 1 & 44 & 1 \\
\hline
\end{tabular}


The two historical artifacts from $41 \mathrm{LN} 321$ attest to a pre-1860 use of the site. Both artifacts were found in the central part of the site (ST 542, 0-16 cm bs and ST 572, 0-20 cm bs) (see Figure 74). The first artifact is a whiteware rim from a tea cup with a green hand-painted line on it, while the second is a plain pearlware body sherd. Pearlware is generally found in pre- 1840 contexts in Texas archaeological sites.

\section{$41 L N 322$}

This site, at the location of the 1936 Fort Boggy Historical Marker, but not apparently the actual location of the 1840 fort (Corbin et al. 1994:14-15), was reported by Corbin et al. (1994:105-106)

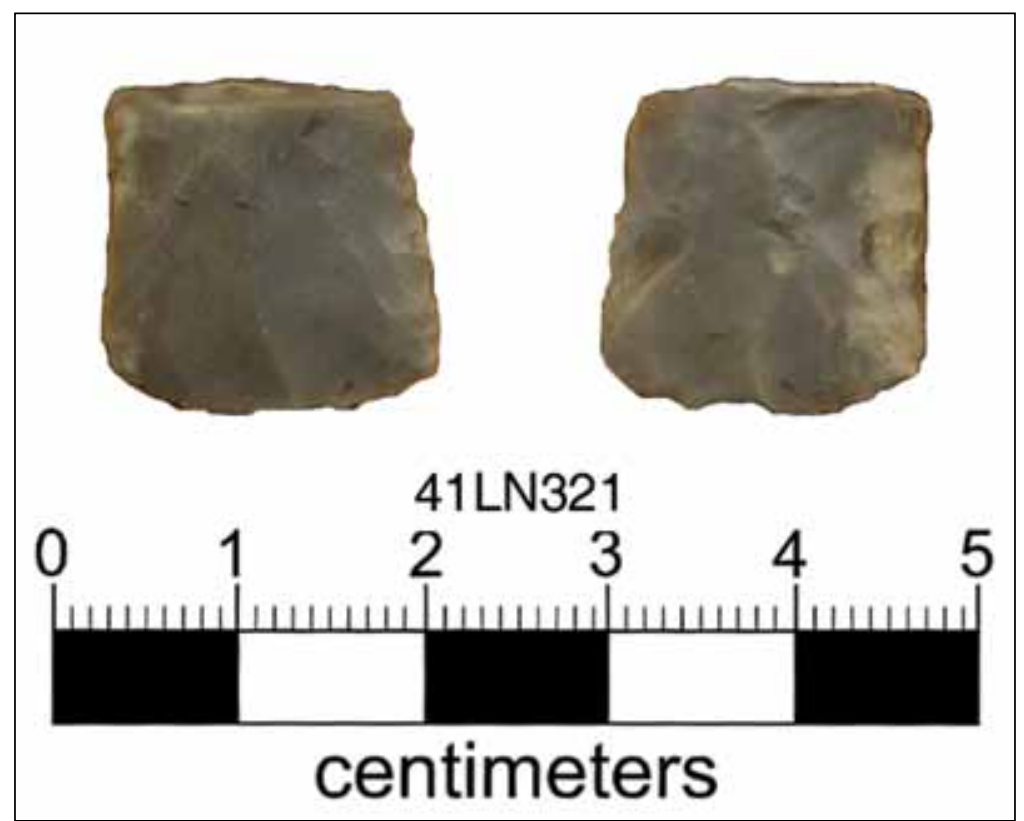

Figure 75. Expanding stem dart point fragment from $41 \mathrm{LN} 321$. to be situated on an eastern extension of a large alluvial terrace landform (300 feet amsl) north of Boggy Creek. An old road bed (41LN331) ran across the site, and an historical boundary fence (4lLN371) was also on 4 lLN322. The site was estimated to cover a 20 m diameter area.

Twelve shovel tests were excavated at 4 lLN322 during the initial site recording effort, and they contained artifacts from 0-60 cm bs. The prehistoric component, of unknown age, included only lithic debris $(n=3)$ (Corbin et al. 1994:106 and Table 7). The more substantial historical archaeological component appeared to date from the mid- to the late nineteenth century, based on the surface collection, metal detecting, and shovel test recovery of mid-nineteenth-century hand-painted whiteware (the site form mentioned the recovery of a green feather-edged or shell-edged sherd as well, but provided no further detail to be able to ascertain its likely age, see Hunter and Miller 1994, 2009), cut nails $(n=2)$, plain whiteware sherds $(n=10)$, bottle glass $(n=2)$, and cast iron fragments $(n=2)$ (Corbin et al. 1994:Table 8).

41 LN322 was readily relocated in our 2010 work because it is situated at the location of the previously mentioned 1936 granite monument to Fort Boggy (Figure 76), which is adjacent to a modern east-west running road that leads to it and then past it. The site area, defined by shovel testing, has an overstory of hardwoods with a thick understory of yaupon holly and mustang grapevines; surface visibility ranged from $10 \%$ to $20 \%$. The area around the 1936 monument is clear, with a ground cover of grasses and bull nettle.

There is a feature of unknown age on $41 \mathrm{LN} 322$, a $1 \times 1.25 \mathrm{~m}$ fire ring of sandstone rocks visible on the surface in the eastern part of the site (see Figure 76); this may represent the remnants of a fairly recent camp fire since some of the rocks are still charcoal-stained. Extensive shovel testing and surface artifacts suggest that $41 \mathrm{LN} 322$ covers a $1600 \mathrm{~m}^{2}$ area ( 0.4 acres), about four times the size estimated during the initial site recording effort. 
FIGURE 76. REDACTED

Figure 76. Map of $41 \mathrm{LN} 322$.

During the 2010 work both prehistoric and historical archaeological deposits were identified in seven positive shovel tests and Unit 322 (see Figure 76). The prehistoric archaeological deposits range from 0 to $40 \mathrm{~cm}$ bs in thickness in the Marques very fine sandy loam sediments, as do the historical archaeological deposits, although the historical and prehistoric artifacts from $41 \mathrm{LN} 322$ are rarely found in the same 
context. The density of prehistoric artifacts in shovel testing is 1.67 per positive shovel test (ST 415,431 , and 432), or 13.4 artifacts per $\mathrm{m}^{2}$. No prehistoric artifacts were found in Unit 322. historical artifacts are better represented on the site, with densities of 4.2 per positive shovel test (ST 418, 420, 424, 431, and 433) or 33.6 artifacts per $\mathrm{m}^{2}$. In Unit 322 , the artifact density is 24.0 artifacts per $\mathrm{m}^{2}$.

Although the collection of historical artifacts from the site is not substantial, it is diverse and temporally wide-ranging. Artifacts are present that represent domestic activities and food storage/consumption, hunting, and architectural activities. The earlier historical archaeological component at $41 \mathrm{LN} 322$, one that may date from ca. 1840 to 1860 , includes two cast iron stove or kettle fragments, plain and decorated whiteware sherds $(n=9)$, two blade gunflints (ST 431 and Unit 322), and one stoneware sherd (Unit 322). Decorated whiteware sherds in this earlier component, all dating from the mid-nineteenth century, include a rim with a blue hand-painted design, as well as a second rim with a blue shell-edged decoration (Figure 77). The non-scalloped rim and impressed lines are indicative of a ca. 1840-1860 style (see Hunter and Miller 1994, 2009). Also dating from this time period is a exterior salt-glazed stoneware sherd; the interior surface is dry (Figure 78 , bottom).

The first gunflint (see Figure 78, top), from Unit 322 , is a blade fragment made from a gray chert. It has been edge trimmed. The flint is $18.9 \mathrm{~mm}$ in width and $3.1 \mathrm{~mm}$ in thickness). The second gunflint is from ST $431(20-40 \mathrm{~cm}$ bs). It is an edgetrimmed blade gunflint made from a dark gray chert (Figure 79). The flint is broken laterally, and is $18.0 \mathrm{~mm}$ in width and 5.4 $\mathrm{mm}$ in thickness.

The later historical archaeological component, dating after 1891 (and perhaps many years after 1891), includes only wire

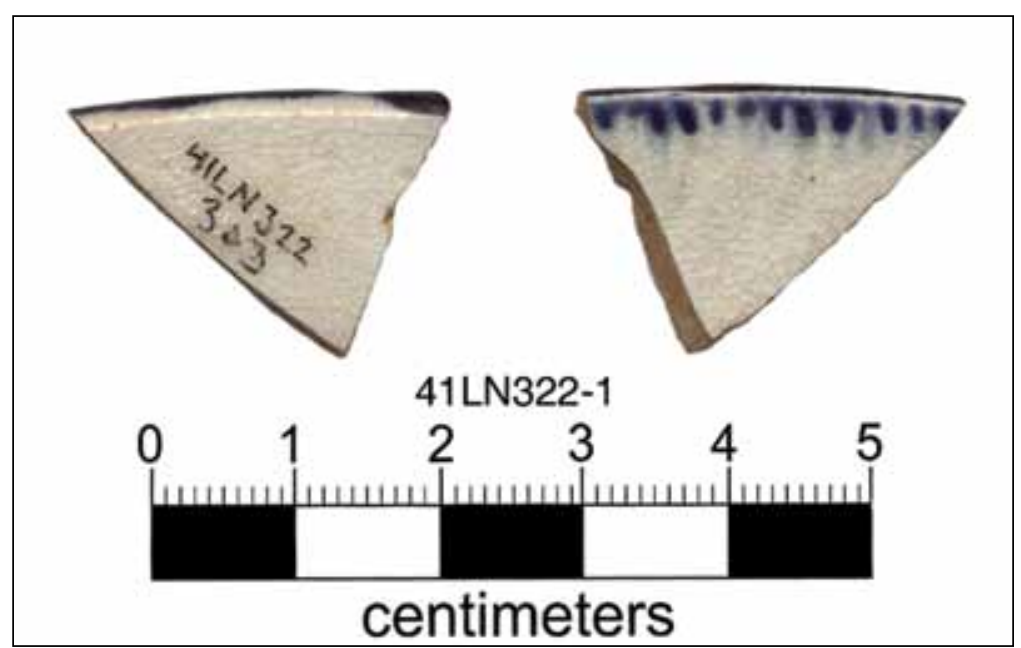

Figure 77. Blue shell-edged whiteware rim sherd from $41 \mathrm{LN} 322$.

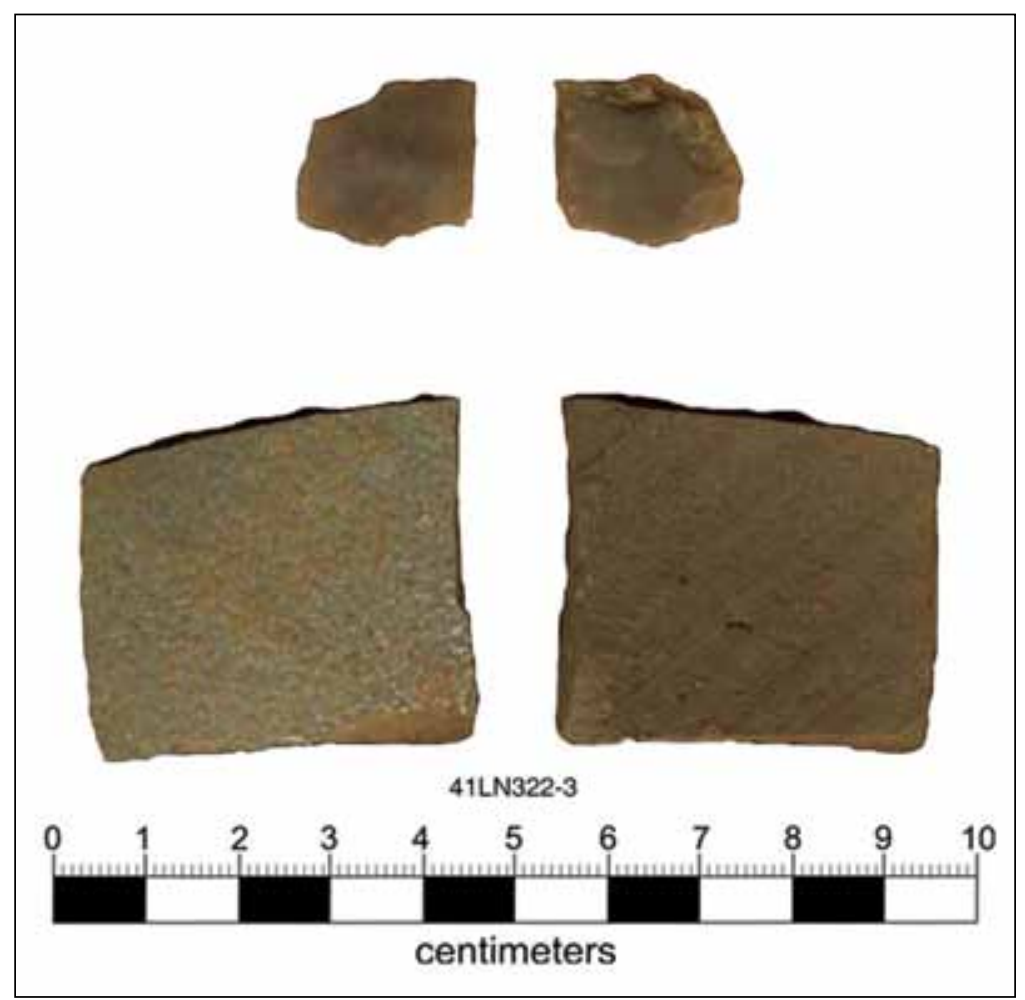

Figure 78. Blade gunflint and salt-glazed stoneware body sherd from 41 LN322: top, blade gunflint (Unit 322, 0-10 cm bs); bottom, salt-glazed stoneware sherd (Unit 322, 0-10 cm bs). 
nails ( $n=16)$, and an iron fence staple. These are from ST 420 and Unit 322 (see Figure 76). These may be the product of the construction of a miniature replica of Fort Boggy that was on the site when the area was open to the public. That replica is currently in storage at the TPWD maintenance area.

The prehistoric artifacts from 41 LN322 include a plain sandy paste pottery sherd, a piece of burned clay (ST $415,0-20 \mathrm{~cm}$ bs), a chert flake tool, and two pieces of lithic debris. The sandy paste body sherd (6.3 $\mathrm{mm}$ thick), Goose Creek Plain, var. unspecified, is from a vessel that was fired and cooled in a

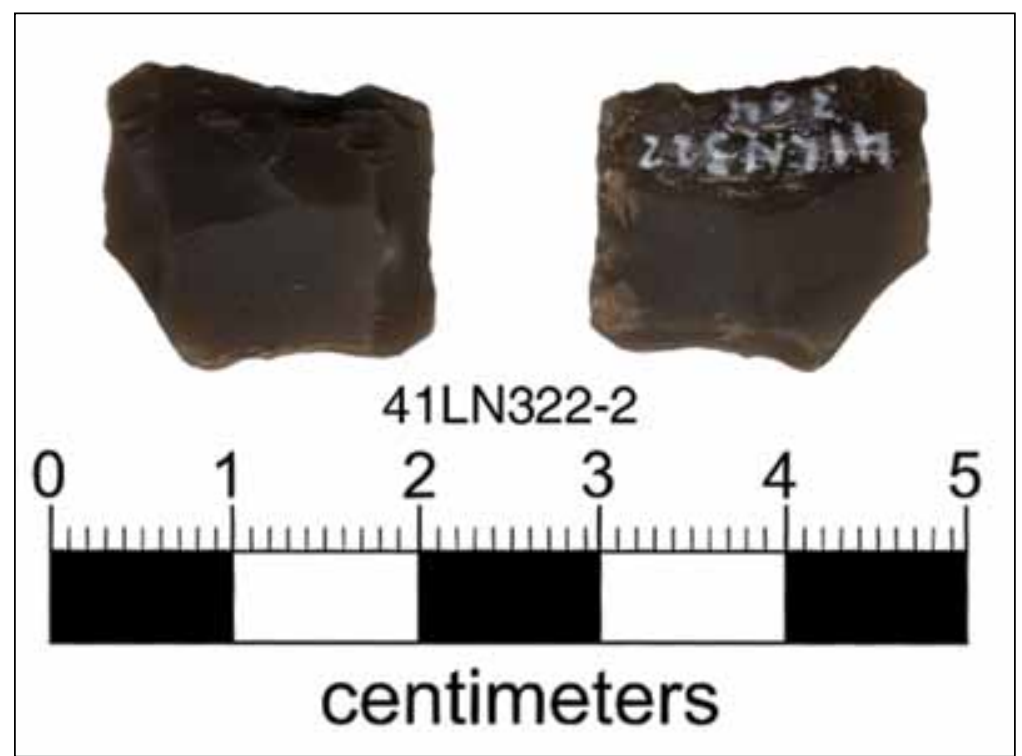

Figure 79. Gunflint from ST 431 at $41 \mathrm{LN} 322$. reducing environment (Teltser 1993:Figure 2b). It was also smoothed on its interior surface.

The chipped stone flake tool has distal use-wear/retouch, with a use length of $11.5 \mathrm{~mm}$. The tool is on a cortical flake of light gray chert. The lithic debris includes a non-cortical flake of petrified wood as well as a non-cortical flake of brownish-gray chert.

\section{LN327, Bull Nettle Site}

41 LN327 was described by Corbin et al. (1994:106) as being situated on an "east-facing ridge," while in actuality the plotted location was on the eastern edge of the large alluvial terrace (290-300 feet amsl) on the north side of Boggy Creek in the central to west-central part of the Park. The site was estimated to cover a $60 \mathrm{~m}$ diameter area ( 0.9 acres). Eighteen shovel test were excavated at $41 \mathrm{LN} 327$, along with metal detecting, and they recovered prehistoric Woodland period artifacts from $0-50 \mathrm{~cm}$ bs during the initial site recording effort.

The prehistoric Woodland period artifacts from the site included a plain sandy paste (Goose Creek Plain, var. unspecified) body sherd, lithic debris $(n=3)$, ground stone tools (two pitted stones), and firecracked rocks (Corbin et al. 1994:106 and Tables 3 and 7).

The historical component was of an unknown age. It was represented by a plain whiteware sherd and a piece of metal chain link (Corbin et al. 1994:106 and Table 8).

The Bull Nettle site, located on the eastern edge of an alluvial terrace (Figure 80), in 2010 had hardwoods with an understory of yaupon holly and mustang grapevines as well as open areas with grasses and bull nettles. Surface visibility was less than $10 \%$.

Extensive shovel testing $(n=23)$ of the landform suggest the Bull Nettle site covers a maximum of ca. $900 \mathrm{~m}^{2}$ in area, but the archaeological deposits are not apparently continuous (or are of such a low density that they could not be detected in the shovel testing) across it. Only prehistoric lithic artifacts were recovered in the 2010 archaeological investigations at the site, but none were temporally diagnostic. These were from 0-20 cm bs in Sildtid loamy fine sand sediments in three shovel tests and Unit 327 . The density 
FIGURE 80. REDACTED

Figure 80. Map of the Bull Nettle site.

of artifacts is 1.33 per positive shovel test (ca. 10.6 artifacts per $\mathrm{m}^{2}$ ) and 8.0 artifacts per $\mathrm{m}^{2}$ in the $50 \times 50$ $\mathrm{cm}$ unit. The lithic debris is from several different raw materials: petrified wood ( $n=2 / 50 \%$ cortical), heattreated quartzite $(n=1 / 0 \%$ cortical), brownish-gray chert ( $1 / 100 \%$ cortical), gray chert ( $1 / 0 \%$ cortical), and brown chert ( $1 / 0 \%$ cortical). These raw materials were likely gathered in nearby stream gravels, or, given the low proportion of cortical flakes among the chert raw materials, previously knapped tools were brought to the site for resharpening and maintenance. 


\section{$41 L N 345$}

Corbin et al. (1994:106-107) reported that 41LN345 was situated on a sandy upland toe slope (300 feet amsl) overlooking the Boggy Creek floodplain. The site was estimated from shovel tests $(n=28)$ to cover a $60 \mathrm{~m}$ diameter area (ca. 0.9 acres), and an old road bed (4 1LN359) ran by its eastern part. Archaeological deposits ranged from 0 to $104 \mathrm{~cm}$ bs.

The prehistoric component at $41 \mathrm{LN} 345$ was of unknown age. Shovel tests excavated at that time recovered only five pieces of lithic debris (Corbin et al. 1994:Table 7).

The historical archaeological component at the site was first noted on an 1933 USDA aerial photograph as a rectangular area, probably a house structure. Shovel tests excavated at that time suggested the site may have first been occupied prior to 1890 because of the recovery of cut nails $(n=5)$. Other historical artifacts from $41 \mathrm{LN} 345$ included plain whiteware sherds $(n=2)$, brick fragments $(n=14)$, flat glass $(n=1$, probably window glass, Corbin et al. 1994:132), cast iron pieces $(n=1)$, and farm equipment $(n=1$, a plow part).

Additional shovel tests $(n=19)$ excavated at $41 \mathrm{LN} 345$ in 2010 indicated that it was situated on a narrow upland toe slope. The site area had a ground cover of grass and bull nettle, with the vegetation on the surrounding parts of the landform including a hardwood overstory and a thick understory of yaupon holly and mustang grapevines. Surface visibility at $41 \mathrm{LN} 345$ is 10-20\%, principally because if an abundance of rodent mounds. There are TPWD primitive campsites at the southern end of the site.

During the 2010 archaeological investigations at Fort Boggy State Park, six shovel tests and Unit 345 contained historical and prehistoric archaeological deposits (see Figure 81). The estimated site extent is $3000 \mathrm{~m}^{2}$ (0.74 acres). The prehistoric deposits were identified in ST 852 at 10-20 cm and in Unit 322 at 80-100 cm bs in Hearne fine sandy loam sediments; the depth of these latter materials initially suggests that the prehistoric archaeological record may be buried to a significant depth. The historical archaeological deposits, on the other hand, also occur at 0-100 cm bs. This suggests there has been a considerable movement of historical artifacts by bioturbation, and this casts doubt on the existence that there are either contextually intact historical or buried prehistoric archaeological deposits. at 41 LN345

The density of prehistoric and historical artifacts in the shovel testing, including animal bone ( $\mathrm{n}=7$, see Appendix 5) from ST 841 , at $41 \mathrm{LN} 345$ is 1.0 and 2.6 artifacts, respectively, per positive shovel test (one shovel test has prehistoric artifacts, while five other shovel tests have only historical artifacts), or 8.0 and 20.8 artifacts per $\mathrm{m}^{2}$. In Unit 345 , the density of prehistoric and historical artifacts is 8.0 and 60.0 per $\mathrm{m}^{2}$, respectively.

The prehistoric artifacts from the site consist of three pieces of lithic debris. All are non-cortical, and they are on gray chert $(n=1)$, petrified wood $(n=1)$, and brownish-gray chert.

The historical artifacts from $41 \mathrm{LN} 345$ suggest that the site was primarily occupied before ca. 1890, and likely also not occupied for a substantial period of time. This is based on the proportion of cut nails (100\%), as such a proportion points to a pre-1886 occupation (see Adams 2002), as does a hand-blown olive green bottle glass lip sherd (Figure 82). The Bristol-glazed stoneware sherd from Unit 345, with blue cobalt squiggles (Figure 83) on its exterior surface, however, implies that the site may have been used in the first quarter of the twentieth century (see Greer 1981) as well. 
FIGURE 81. REDACTED

Figure 81. Map of 41 LN345. 
Overall, the historical artifacts at $41 \mathrm{LN} 345$ are representative of domestic and architectural activities. The domestic artifacts include Bristol-glazed stoneware $(n=1)$, olive green bottle glass sherds $(\mathrm{n}=2)$, and a cast iron fragment.

Architectural items in the assemblage are cut nails ( $n=8)$, unidentified nail shanks ( $n=2)$, and hand-made brick fragments ( $n=7$ ). These suggest a wood-framed structure was built on the site, and it likely had a brick chimney foundation.

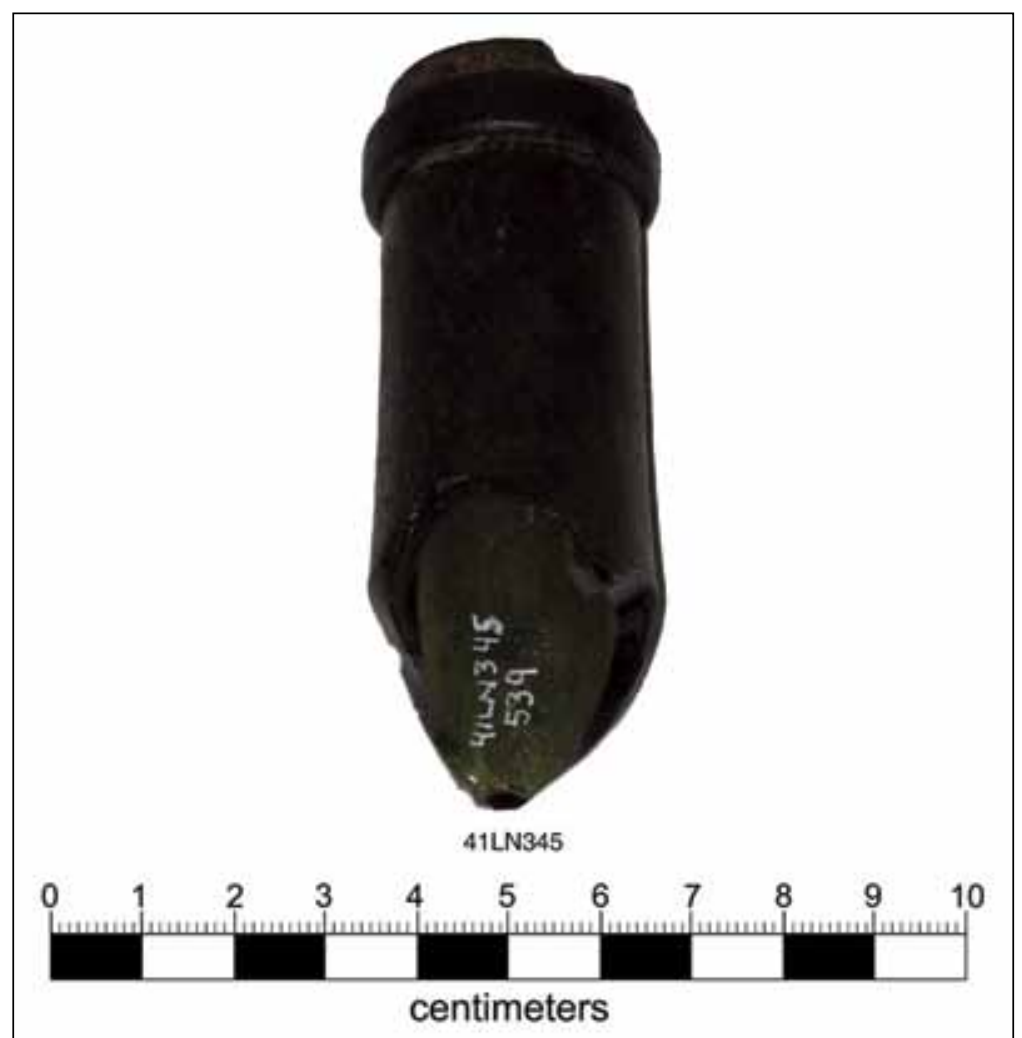

Figure 82. Olive green hand-blown bottle glass lip sherd from 41LN345, Unit 345, 30-40 cm bs.
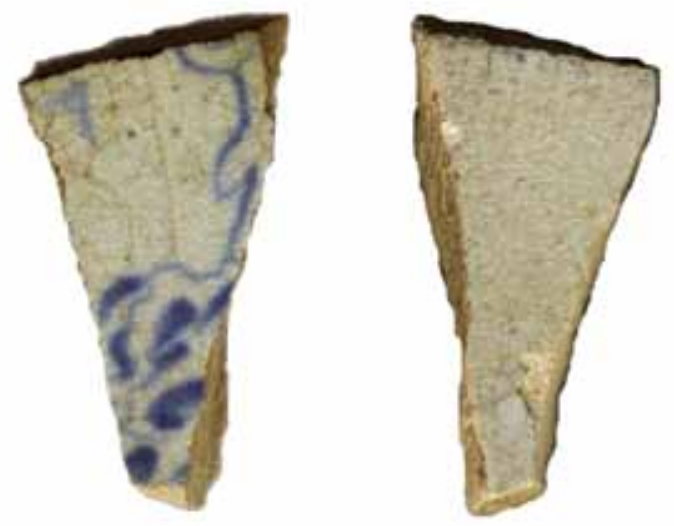

\section{LN345}

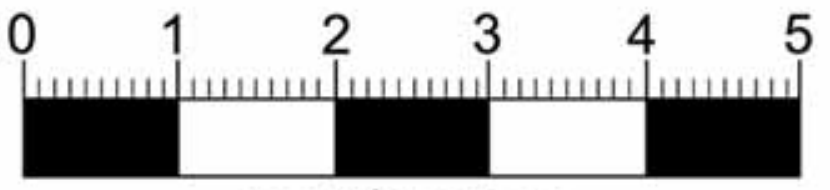

centimeters

Figure 83. Bristol-glazed stoneware with blue cobalt squiggle decorations, Unit 345, 0-10 cm bs. 


\section{Chapter 5}

\section{Summary}

\section{The Known Prehistoric and Historical Archaeological Record}

The 2010 archaeological investigations at Fort Boggy State Park, in conjunction with the Corbin et al. (1994) findings, provide specific information on the use of the park area over time from the artifacts found on them (see above), and thus it is possible to identify likely periods of most intensive use (Table 16) during both prehistoric and historical eras in this part of East Central Texas. In general, based primarily on survey and shovel test investigations, rather than intensive test excavations of data recovery work, the park area was used periodically throughout prehistoric times, beginning about 10,000 years ago, with a few periods of more intensive settlement in the prehistoric era, and then settled and used more continuously for farming after ca. 1870.

Table 16. Estimated age of sites at Fort Boggy State Park, based on Corbin et al. (1994) and the 2010 relocation investigations.* $^{*}$

\begin{tabular}{|c|c|c|c|c|c|c|c|}
\hline Site No. & UID PRE. & A & $\mathrm{W}$ & $\mathrm{LP}$ & PRE-1870 & $1870-1900$ & POST-1900 \\
\hline 41LN298 & $\mathrm{X}$ & - & - & - & $?$ & $?$ & $\mathrm{X}$ \\
\hline 41LN299 & $\mathrm{X}$ & - & - & - & - & - & $\mathrm{X}$ \\
\hline 41LN300 & - & - & - & - & - & $\mathrm{x}$ & - \\
\hline 4lLN301 & $\mathrm{X}$ & - & - & - & - & $\mathrm{X}$ & - \\
\hline 4lLN302 & $\mathrm{x}$ & - & - & - & $\mathrm{X}$ & $\mathrm{x}$ & - \\
\hline 4lLN303 & $\mathrm{x}$ & - & - & - & $?$ & $\mathrm{x}$ & $?$ \\
\hline 4lLN304 & $\mathrm{x}$ & - & - & - & $?$ & $?$ & $?$ \\
\hline 4lLN305 & - & - & - & - & - & - & $\mathrm{X}$ \\
\hline 41LN306 & - & - & - & - & - & $\mathrm{X}$ & $\mathrm{X}$ \\
\hline 41LN307 & - & - & - & - & - & $\mathrm{x}$ & $\mathrm{X}$ \\
\hline 41LN308 & - & $\mathrm{X}$ & $\mathrm{X}$ & $\mathrm{X}$ & $?$ & $?$ & $?$ \\
\hline 41LN309 & $\mathrm{x}$ & - & - & - & $\mathrm{X}$ & $\mathrm{x}$ & $\mathrm{X}$ \\
\hline 41LN310 & - & $\mathrm{X}^{* *}$ & $\mathrm{X}$ & - & - & - & $\mathrm{X}$ \\
\hline 4lLN311 & - & - & - & - & - & $\mathrm{x}$ & $\mathrm{X}$ \\
\hline 4lLN312 & $\mathrm{x}$ & - & - & - & $\mathrm{X}$ & - & $\mathrm{X}$ \\
\hline $41 \mathrm{LN} 313$ & - & - & - & - & - & - & $\mathrm{X}$ \\
\hline 4lLN314 & $\mathrm{x}$ & - & - & - & - & $\mathrm{X}$ & $\mathrm{X}$ \\
\hline $41 \mathrm{LN} 315$ & - & - & - & - & - & - & $\mathrm{X}$ \\
\hline 4lLN316 & $\mathrm{x}$ & - & - & - & - & - & - \\
\hline $41 \mathrm{LN} 317$ & - & $\mathrm{X}$ & - & - & - & - & - \\
\hline \multicolumn{8}{|c|}{$\begin{array}{l}\mathrm{X}=\text { present; } ?=\text { questionable } \\
\text { * Does not include sites documented in } 2010 \text { only through photography and field observations. } \\
\text { ** possible Late Paleoindian-Early Archaic; UID Pre. = unidentified prehistoric; } \mathrm{A}=\text { Archaic; } \mathrm{W}= \\
\text { Woodland; LP = Late Prehistoric }\end{array}$} \\
\hline
\end{tabular}


Table 16, continued.

\begin{tabular}{|c|c|c|c|c|c|c|c|}
\hline Site No. & UID PRE. & $\mathrm{A}$ & $\mathrm{W}$ & $\mathrm{LP}$ & PRE-1870 & $1870-1900$ & POST-1900 \\
\hline 41LN318 & - & - & $\mathrm{X}$ & $\mathrm{X}$ & - & - & $\mathrm{X}$ \\
\hline $41 \mathrm{LN} 319$ & $\mathrm{x}$ & - & - & - & - & $\mathrm{x}$ & $\mathrm{x}$ \\
\hline 41LN320 & $\mathrm{X}$ & - & - & - & - & - & - \\
\hline $41 \mathrm{LN} 321$ & - & $\mathrm{X}$ & $\mathrm{X}$ & - & $\mathrm{x}$ & $\mathrm{x}$ & - \\
\hline $41 \mathrm{LN} 322$ & - & - & $\mathrm{X}$ & - & $\mathrm{X}$ & $\mathrm{x}$ & - \\
\hline $41 \mathrm{LN} 323$ & - & - & $\mathrm{x}$ & $\mathrm{X}$ & - & - & - \\
\hline $41 \mathrm{LN} 324$ & $\mathrm{X}$ & - & - & - & - & $\mathrm{X}$ & $\mathrm{x}$ \\
\hline 4lLN325 & - & $\mathrm{X}$ & $\mathrm{x}$ & $\mathrm{x}$ & $\mathrm{x}$ & $?$ & ? \\
\hline $41 \mathrm{LN} 326$ & - & - & $\mathrm{X}$ & - & - & - & - \\
\hline 4lLN327 & - & - & $\mathrm{X}$ & - & ? & $?$ & $?$ \\
\hline $41 \mathrm{LN} 328$ & $\mathrm{X}$ & - & - & - & - & - & - \\
\hline 4lLN329 & $\mathrm{X}$ & - & - & - & - & - & - \\
\hline 4 lLN336 & - & - & - & - & - & - & $\mathrm{x}$ \\
\hline 41LN337 & - & - & - & - & - & - & $\mathrm{x}$ \\
\hline $41 \mathrm{LN} 338$ & $\mathrm{X}$ & - & - & - & - & - & - \\
\hline 41LN339 & $\mathrm{X}$ & - & - & - & - & - & - \\
\hline 4 lLN340 & $\mathrm{x}$ & - & - & - & - & - & - \\
\hline 4 lLN34 1 & - & - & $\mathrm{X}$ & $\mathrm{x}$ & - & - & - \\
\hline 4 lLN342 & $\mathrm{X}$ & - & - & - & ? & $?$ & $?$ \\
\hline 4 lLN343 & - & - & $\mathrm{X}$ & - & - & - & - \\
\hline 4 lLN344 & $\mathrm{X}$ & - & - & - & - & - & - \\
\hline 41LN345 & $\mathrm{X}$ & - & - & - & $\mathrm{x}$ & $\mathrm{X}$ & $\mathrm{X}$ \\
\hline $41 \mathrm{LN} 346$ & $\mathrm{x}$ & - & - & - & - & - & - \\
\hline 4lLN347 & $\mathrm{x}$ & - & - & - & - & - & - \\
\hline 41LN348 & $\mathrm{X}$ & - & - & - & - & - & - \\
\hline 41LN349 & - & $\mathrm{X}$ & - & - & - & - & - \\
\hline 41LN350 & $\mathrm{X}$ & - & - & - & - & - & - \\
\hline 4lLN351 & - & - & $\mathrm{x}$ & - & ? & $?$ & $?$ \\
\hline 41LN352 & - & - & - & - & - & - & $\mathrm{X}$ \\
\hline 4lLN353 & - & - & - & - & - & $\mathrm{X}$ & $\mathrm{X}$ \\
\hline 4lLN355 & - & - & - & - & - & $?$ & $\mathrm{x}$ \\
\hline 4lLN356 & - & - & - & - & - & $\mathrm{x}$ & $\mathrm{x}$ \\
\hline 41LN357 & $\mathrm{X}$ & - & - & - & - & - & $\mathrm{x}$ \\
\hline 41LN358 & $\mathrm{X}$ & - & - & - & - & $\mathrm{X}$ & $\mathrm{x}$ \\
\hline 4lLN363 & $\mathrm{X}$ & - & - & - & - & - & - \\
\hline 4lLN364 & $\mathrm{X}$ & - & - & - & - & - & - \\
\hline 4lLN365 & - & - & - & - & - & - & $\mathrm{x}$ \\
\hline
\end{tabular}

$\mathrm{X}=$ present; $?=$ questionable

* Does not include sites documented in 2010 only through photography and field observations.

** possible Late Paleoindian-Early Archaic; UID Pre. = unidentified prehistoric; $\mathrm{A}=$ Archaic; $\mathrm{W}=$ Woodland; LP = Late Prehistoric 
Table 16, continued.

\begin{tabular}{|c|c|c|c|c|c|c|c|}
\hline Site No. & UID PRE. & $\mathrm{A}$ & $\mathrm{W}$ & $\mathrm{LP}$ & PRE-1870 & $1870-1900$ & POST-1900 \\
\hline 41LN367 & - & - & - & - & $?$ & - & $?$ \\
\hline $41 \mathrm{LN} 370$ & - & - & - & - & - & - & $\mathrm{X}$ \\
\hline 41LN372 & $\mathrm{x}$ & - & - & - & - & $\mathrm{x}$ & $?$ \\
\hline $41 \mathrm{LN} 380$ & - & - & - & - & - & - & $\mathrm{X}$ \\
\hline 41LN381 & - & - & - & - & - & - & $\mathrm{X}$ \\
\hline $\begin{array}{l}\text { Total } \\
\text { Components }\end{array}$ & 30 & 6 & 12 & 5 & 7 & 18 & 28 \\
\hline $\begin{array}{l}\text { \% Sites with } \\
\text { specific } \\
\text { components }\end{array}$ & $48 \%$ & $9.7 \%$ & $19 \%$ & $8 \%$ & $11.3 \%$ & $29 \%$ & $46 \%$ \\
\hline Total sites & & & \multicolumn{5}{|c|}{62} \\
\hline \multicolumn{5}{|c|}{ Total no. of components, all sites } & \multicolumn{2}{|c|}{106} & \\
\hline \multicolumn{5}{|c|}{$\%$ Sites with prehistoric component only } & \multicolumn{2}{|c|}{$26 \%$} & \\
\hline \multicolumn{5}{|c|}{$\%$ Sites with historical component only } & \multicolumn{2}{|c|}{$27 \%$} & \\
\hline \multicolumn{5}{|c|}{$\%$ Sites with prehistoric and historical components } & \multicolumn{2}{|c|}{$47 \%$} & \\
\hline
\end{tabular}

$\mathrm{X}=$ present; $?$ = questionable

* Does not include sites documented in 2010 only through photography and field observations.

** possible Late Paleoindian-Early Archaic; UID Pre. = unidentified prehistoric; $\mathrm{A}=$ Archaic; $\mathrm{W}=$ Woodland; LP = Late Prehistoric

As Table 16 shows, more than $73 \%$ of the Fort Boggy State Park sites have at least one prehistoric component, even though in most cases that component is indicative of nothing more than a prehistoric component of unknown age with some amount of lithic debris from chipped stone tool manufacturing and maintenance activities (Figure 84; see also Table 16). Almost $47 \%$ of all the sites at the Park have both a prehistoric and historical component (see Table 16).

Of the prehistoric sites where a specific and temporally-bounded archaeological component can be identified, it is sites of Woodland period age (ca. 500 B.C.-A.D. 800) that are most commonly identified on a variety of landforms across the Park (Figure 85). Radiocarbon dates from $41 \mathrm{LN} 308$ and the Black Finger Tip site (4lLN325) also confirm that two extensive midden deposits at the site accumulated primarily during this period, between A.D. 432 and 772. Woodland period sites, or sites with multiple prehistoric components, constitute $55 \%$ of the sample of sites where prehistoric components were identified (see Table 16). Archaic and Late Prehistoric components on prehistoric sites account for $23 \%$, respectively, of all the identified prehistoric components; one radiocarbon date from $41 \mathrm{LN} 308$ identified use of the site during the early part of the late Prehistoric period (A.D. 935-987). Archaic sites are not particularly common at the Park, and temporal diagnostics recovered suggest that much of the Park was only used by Archaic foragers after about 4000 years ago. It is possible, however, that many of the sites that would date to the Archaic period are either deeply buried in alluvial and upland settings, or that pre-4000 years B.P. Archaic sites were eroded away during the warmer and drier middle Holocene period. Late Archaic deposits have been identified beneath the Woodland period midden at the Black Finger Tip site, and these date to 824-904 B.C.

The majority of the Woodland and Late Prehistoric sites at Fort Boggy are situated on landforms that are in proximity to Boggy Creek and the Boggy Creek floodplain, although two of the sites-Clear Cut (4lLN317) and Black Walnut House (4lLN318)—are found along small tributary streams some distance 
from Boggy Creek (see Figure 85). These sites are on upland toe slopes, alluvial terraces, and low lying landforms that project into the Boggy Creek floodplain.

Three of these Woodland to Late Prehistoric sites, 4lLN308, the Black Finger Tip site (41LN325), and the Last Chance Quarry site (4lLN341), have deep midden deposits (see Figure 85); two of the middens have been radiocarbon-dated to Woodland period times. Their preservation indicates that sometime during this period, a more intensive and sustained settlement pattern began to develop among Woodland and Late Prehistoric peoples. Such sites may have seen occupations that were more than seasonal for a number of years, and we would expect such sites to contain other evidence of more permanent settlement, including house structures, storage pits, and small cemeteries (cf. Gadus et al. 2002).

Approximately $74 \%$ of the Fort Boggy State Park sites have historical archaeological components (Figure 86; see also Table 16). Almost $47 \%$ of all the sites at the Park have both a prehistoric and historical component (see Table 16). The historical components occur in several clusters on the north and south sides of Boggy Creek, and perhaps these clusters represent groups of related families. Most of the historical sites are either on the large alluvial terrace just north of Boggy Creek, or along roads that traversed upland ridges and slopes along tributaries to Boggy Creek; water from springs or shallow aquifers may have been more accessible in these settings.

Of the historical sites where a specific and temporally-bounded archaeological component can be identified, it is sites of post-1900 age that are most commonly identified across the Park. Sites with post1900 occupations account for $52 \%$ of the sample of historical sites with identifiable components (see Table 16). Pre-1870 components on historical sites account for $13.2 \%$ of the identified historical components at Fort Boggy (Figure 87), and conversely 34\% of the historical sites with components have a ca. 1870-1900 occupation. Clearly, the Fort Boggy State Park area was occupied intensively in historical times after 1870 through the mid-twentieth century.

The pre-1870 sites contain artifacts (mainly decorated whiteware ceramics) that suggest they may have been occupied as early as ca. 1840, when Fort Boggy was occupied. These early Anglo-American settlements do not cluster together (see Figure 87), as if they were part of a nucleated settlement in and around a fort or blockhouse. Two of the sites are near or at the Fort Boggy marker (the Cedar House site [4lLN309] and 4lLN322) on a large alluvial terrace; three others are in the uplands on either side of Boggy Creek (4lLN302, the Halfway House site [4lLN312], and 41LN345); and the remaining pre-1870 sites are situated along the southern edges of the large alluvial terrace on landforms that project south into the Boggy Creek floodplain (4lLN321 and the Black Finger Tip site [4lLN325]).

Table 17 provides basic information on site size, artifact density, and depth of the archaeological deposits for each of the sites that were shovel tested and had a 50 x $50 \mathrm{~cm}$ unit excavated there. The single component historical sites are small in size, ranging from 0.1 to 1.2 acres in size, with archaeological deposits that are 10-60 cm in thickness; most of these sites have deposits that are less than $40 \mathrm{~cm}$ in thickness, however. They generally have the remains of rock/brick chimney foundations as well as evidence of house structures. Six of these sites (46\%) have considerable densities per $\mathrm{m}^{2}$ of discarded and fragmentary domestic goods and containers (ceramic and glass) and architectural materials (especially nails and/or window glass), while the others do not. This implies either an abundance of material remains in use at some of the sites, or each had more lengthy occupations in the historical era than did the historical sites with a paucity of material remains and trash. 
Table 17. Site Summaries, Fort Boggy State Park.

\begin{tabular}{|c|c|c|c|c|}
\hline Site No. & SITE SIZE (M2) & $\begin{array}{c}\text { SHOVEL TEST ARTIFACT } \\
\text { DENSITY (PER PST) }\end{array}$ & $\begin{array}{c}50 \text { x } 50 \text { CM ARTIFACT } \\
\text { DENSITY (PER M2) }\end{array}$ & $\begin{array}{c}\text { DEPTH OF DEPOSITS } \\
\text { (CM BS) }\end{array}$ \\
\hline \multicolumn{5}{|c|}{ Single component, historical } \\
\hline 41LN300-H & 3000 & 4.8 & 232 & $0-40$ \\
\hline 41LN305-H & 2800 & 4.25 & 32 & $0-40$ \\
\hline 41LN306-H & 4800 & 3.5 & 144 & $0-40$ \\
\hline 41LN307-H & 1750 & 11 & 320 & $0-20$ \\
\hline 41LN311-H & 1800 & 10.5 & 52 & $0-30$ \\
\hline 41LN313-H & 1050 & 2 & 56 & $0-40$ \\
\hline 41LN315-H & 1000 & - & 4 & $0-10$ \\
\hline 41LN318-H & 3825 & 3 & 92 & $0-60$ \\
\hline 41LN337-H & 2400 & 2 & 8 & $0-20$ \\
\hline 4lLN353-H & 1200 & 15.3 & 292 & $0-60$ \\
\hline 41LN355-H & 2500 & 4.3 & 172 & $0-32$ \\
\hline 4lLN356-H & 2000 & 3.2 & 40 & $0-20$ \\
\hline 41LN365-H & 400 & 2.5 & 16 & $0-20$ \\
\hline \multicolumn{5}{|c|}{ Multi-component historical and prehistoric: main component, historical } \\
\hline 41LN298-P & 900 & 1 & 4 & $20-70$ \\
\hline 41LN298-H & - & 1.5 & 8 & $0-40$ \\
\hline 41LN301-P & 400 & 2 & - & $20-31$ \\
\hline 41LN301-H & - & 1 & 16 & $0-20$ \\
\hline 41LN302-H & 1400 & 1.75 & 20 & $0-40$ \\
\hline 41LN302-P & - & - & 4 & $0-10$ \\
\hline 41LN303-H & 1800 & 1.33 & 56 & $0-50$ \\
\hline 41LN303-P & - & 1 & 4 & $10-60$ \\
\hline 41LN309-H & 6000 & 12.9 & 32 & $0-40$ \\
\hline 41LN309-P & - & 1 & 4 & $0-30$ \\
\hline 41LN312-H & 1600 & 1.8 & 32 & $0-20$ \\
\hline 41LN312-P & - & - & 4 & $0-10$ \\
\hline 41LN314-H & 2150 & 2.14 & 12 & $0-90$ \\
\hline 41LN314-P & - & - & 4 & $20-30$ \\
\hline 41LN319-H & 4750 & 2.67 & 60 & $0-52$ \\
\hline 41LN319-P & - & 1 & - & $0-20$ \\
\hline 41LN322-P & 1600 & 1.67 & - & $0-40$ \\
\hline 41LN322-H & - & 4.2 & 24 & $0-40$ \\
\hline 41LN324-H & 2500 & 9.9 & 228 & $0-60$ \\
\hline 41LN324-P & - & - & 4 & $20-30$ \\
\hline 4lLN345-P & 3000 & 1 & 8 & $10-100+$ \\
\hline 41LN345-H & - & 2.6 & 60 & $0-100+$ \\
\hline
\end{tabular}


Table 17, continued

\begin{tabular}{|c|c|c|c|c|}
\hline Site No. & SITE SIZE (M2) & $\begin{array}{c}\text { SHOVEL TeSt ARTIFACt } \\
\text { DENSITY (PER PST) }\end{array}$ & $\begin{array}{l}50 \text { x } 50 \text { CM ARTIFACT } \\
\text { DENSITY (PER M2) }\end{array}$ & $\begin{array}{l}\text { DEPTH OF DEPOSITS } \\
\quad \text { (CM BS) }\end{array}$ \\
\hline 4lLN358-H & 400 & 1 & 4 & $0-40$ \\
\hline 4lLN358-P & - & 1 & 4 & $60-100+$ \\
\hline 4lLN372-H & 1125 & 8.7 & 284 & $0-60$ \\
\hline 4lLN372-P & - & - & 4 & $0-10$ \\
\hline \multicolumn{5}{|c|}{ Singe component, prehistoric } \\
\hline 41LN308-P & 18,000 & 5.6 & 176 & $0-100+$ \\
\hline 41LN310-P & 4900 & 4.25 & 72 & $0-100+$ \\
\hline 41LN316-P & 600 & 2 & 32 & $0-40$ \\
\hline 41LN317-P & 400 & 1.5 & 4 & $10-50$ \\
\hline 41LN320-P & 500 & 1 & 8 & $0-100+$ \\
\hline 41LN323-P & 2100 & 5 & 76 & $20-100+$ \\
\hline 41LN326-P & 1500 & 1.67 & 12 & $20-100+$ \\
\hline 4lLN327-P & 900 & 1.33 & 8 & $0-20$ \\
\hline 4lLN328-P & 800 & 2 & 4 & $20-100+$ \\
\hline 41LN329-P & 400 & 2 & 8 & $80-100+$ \\
\hline 41LN338-P & 225 & - & 16 & $20-100+$ \\
\hline 41LN339-P & 400 & 1 & 4 & $60-100+$ \\
\hline 41LN340-P & 800 & 5.3 & 40 & $0-100+$ \\
\hline 4lLN341-P & 5600 & 3.9 & 92 & $20-100+$ \\
\hline 4lLN342-P & 400 & 5 & 20 & $0-80$ \\
\hline 4lLN343-P & 2000 & 7 & 272 & $0-100+$ \\
\hline 4lLN344-P & 3000 & 1.57 & 40 & $0-100+$ \\
\hline 4lLN346-P & 225 & 1 & 12 & $0-100+$ \\
\hline 4lLN348-P & 400 & 2 & 40 & $20-90$ \\
\hline 4lLN349-P & 900 & 2 & 20 & $20-60$ \\
\hline 41LN350-P & 400 & 1 & 12 & $0-90$ \\
\hline 4lLN363-P & 400 & 1 & 8 & $30-47$ \\
\hline 4lLN364-P & 400 & 1 & 4 & $80-100+$ \\
\hline \multicolumn{5}{|c|}{ Multi-component historical and prehistoric: main component, prehistoric } \\
\hline 41LN299-P & 6000 & 2.4 & 104 & $0-100+$ \\
\hline 4lLN299-H & - & 2.5 & - & $0-60$ \\
\hline 4lLN304-H & 1000 & - & - & - \\
\hline 4lLN304-P & - & 1 & 4 & $0-80$ \\
\hline 41LN321-P & 14,000 & 2 & 16 & $13-100+$ \\
\hline $41 \mathrm{LN} 321-\mathrm{H}$ & - & 1 & - & $0-20$ \\
\hline 41LN325-P & 18,900 & 8.8 & 356 & $0-100+$ \\
\hline 4lLN325-H & - & 3 & 4 & $0-80$ \\
\hline 4lLN347-P & 1000 & 1.33 & 32 & $0-100+$ \\
\hline 4lLN347-H & - & - & 4 & $20-30$ \\
\hline
\end{tabular}


Table 17, continued

\begin{tabular}{|c|c|c|c|c|}
\hline Site No. & SITE SIZE (M2) & $\begin{array}{c}\text { SHOVEL TEST ARTIFACT } \\
\text { DENSITY (PER PST) }\end{array}$ & $\begin{array}{c}50 \text { x } 50 \text { CM ARTIFACT } \\
\text { DENSITY (PER M2) }\end{array}$ & $\begin{array}{c}\text { DEPTH OF DEPOSITS } \\
\text { (CM BS) }\end{array}$ \\
\hline 41LN351-P & 400 & 3.5 & 8 & $0-92$ \\
\hline 4lLN351-H & - & - & 4 & $0-10$ \\
\hline 41LN357-P & 400 & 2 & 4 & $20-80$ \\
\hline 4lLN357-H & - & 1 & - & $60-80$ \\
\hline
\end{tabular}

$\mathrm{P}=$ prehistoric component $\mathrm{H}=$ historical component

The same can be said for the multi-component sites where the historical component represents the primary use of the sites (see Table 17). The sites are small, have a wide range in the thickness of their historical archaeological deposits, and in general artifact densities are relatively low, suggesting that these sites were not occupied for long periods of time. The exceptions are $41 \mathrm{LN} 324$ and 4lLN372, which have substantial deposits of material goods and in the case of $41 \mathrm{LN} 372$, also have preserved faunal remains, eggshell fragments, and pieces of burned clay among the archaeological remains.

The prehistoric components-including the single component sites and the multi-component sites where the prehistoric archaeological deposits represent the primary component-tend to have deep archaeological deposits, with 73\% of the primary prehistoric components have deposits more than 90-100 $\mathrm{cm}$ thick, and another $10 \%$ with deposits $60-80 \mathrm{~cm}$ thick (see Table 17). There are hints in the shovel test and $50 \times 50 \mathrm{~cm}$ findings that some of these deposits may be stratified in the deep sandy sediments along Boggy Creek and in its surrounding upland landforms, while others appear to have been buried by more recent sandy sediments. At the Black Finger Tip site (4lLN325), Late Archaic deposits are buried beneath a thick Woodland period midden.

In general, the primary component prehistoric sites at Fort Boggy State Park, as well as the prehistoric components found at sites where the historical component is primary (see Table 17), have low densities of artifacts, primarily consisting of pieces of lithic debris from chipped stone tool manufacture. More than $72 \%$ of the prehistoric components have artifact densities that are less than 20 artifacts per $\mathrm{m}^{2}$, and another $12 \%$ have densities of 30-40 artifacts per $\mathrm{m}^{2}$. None of them apparently were used in a sustained way during their occupations, but rather may have been used episodically over hundreds of years, leaving a light trace of artifacts that apparently accumulated over lengthy periods time in the sandy sediments in the Boggy Creek basin.

There are only five (12\%) of the prehistoric sites at Fort Boggy State Park that have high densities of archaeological remains (>92 artifacts per $\mathrm{m}^{2}$ ), including chipped stone tools and lithic debris, and/ or ceramic vessel sherds, nutshells, animal bones, and other artifacts: 41LN299, 4 lLN308, Black Finger Tip (4lLN325), Last Chance Quarry (4lLN341), and Fern Slope (4lLN343). Three of the sites have midden deposits (two dated to Woodland period times), and four of the five sites have deposits that range from 1.4 to 4.7 acres. These are sizeable Woodland and Late Prehistoric settlements on Boggy Creek and tributaries (see Figures 84 and 85), with thick archaeological deposits that contain accumulations of remains not generally seen at the other Fort Boggy sites (especially quantities of animal bone, charred plant remains, and burned clay). These sites were apparently occupied over longer spans of time, and/or were more intensively occupied when they were used, and may be characterized as camps that would have had structures and other features marking their residential use (cf. Gadus et al. 2002). 


\section{Untested Historical Sites}

The 24 historical sites at Fort Boggy State Park that were not subjected to shovel testing or $50 \mathrm{x} 50 \mathrm{~cm}$ unit excavations include road cuts, a borrow pit, a family campsite, historical fences/property line, a dump, corrals, and the location of a barn. The locations of each of these sites were visited during the course of the 2010 archaeological site relocation investigations, and UTMs were obtained from them as well as their current conditions. None of these sites appear to have any archaeological potential, and in several cases, although the locations of sites as recorded by Corbin et al. (1994) was confirmed, there was no physical evidence or archaeological remains at those locations.

The sections of 11 different old road cuts (nineteenth and twentieth century in age, 4lLN330, 4lLN331, 41LN332, 4 lLN333, 4 1LN334, 4 lLN335, 4lLN359, 41LN360, 41LN361, 4lLN362, and 4lLN373) are of varying lengths and depths $(0.5-4 \mathrm{~m})$ across the park landscape. The total length of these old road cuts in the park is ca. $14.1 \mathrm{~km}$. These old road cuts appear to be intact.

$41 \mathrm{LN} 336$ is a remnant of a twentieth-century borrow pit used for road construction and is marked by piles of bricks, concrete culvert fragments, and wood planks. The site has been thoroughly disturbed.

The family campsite (4lLN352) was donated to TPWD when the state park was established. It has visible evidence of a picnic table, camp grill, fire ring, and an old bath house.

The historical fences/property line boundaries are simply that: lines of barbed wire fencing along property boundaries, either embedded in trees, on the surface, or buried in the ground (41LN354, 41LN371). The total length of these historical fences is $2.24 \mathrm{~km}$ across the state park.

The twentieth-century dump site (41LN368) was found to be in a section of an old road cut (41LN322). It was marked by bricks, various kinds of metal, and metal cans.

Site 4 lLN370 was recorded by Corbin et al. (1994) as the location of a barn visible on aerial photographs. Because of the UTMs provided on the original site form, the location of this twentieth-century barn was determined in the 2010 archaeological survey. There were no historical artifacts noted at this location (since this barn is within the boundaries of $41 \mathrm{LN} 321$, an expansive prehistoric archaeological sites, shovel tests excavated to determine the boundary of that site crossed the UTM-plotted location of 41LN370, but no artifacts were recovered there), and no structural evidence of the barn itself.

Corbin et al. (1994) recorded from aerial photographs, and only very minimal archaeological work, a number of old corrals at Fort Boggy State Park. These include 4lLN366, 4lLN367, 41LN369, 4lLN374, $41 \mathrm{LN} 375,41 \mathrm{LN} 380$, and $41 \mathrm{LN} 381$. In most cases, these corrals have not left much in the way of archaeological evidence, at least as based on the results of the 2010 archaeological survey investigations. At 4lLN366, 4lLN367, and 4lLN369, these sites as determined by UTM plottings (based on Corbin et al. [1994]) are in large open fields, and no features, fence lines, or artifacts were apparent to assist in the locating of old corral fences. At 4lLN374, there was no evidence of a 1930s corral or any artifacts associated with such a feature, only modern wood and metal sheeting feeding stations. The historical corrals at 41LN375, 41LN380, and 4lLN381 are marked by hog wire fencing, a fence berm, galvanized wash tubs, enamel pots, barrel straps, and bucket fragments (4lLN375 and 4lLN381), as well as a concrete water trough and underground piping (4lLN380). 
FIGURE 84. REDACTED

Figure 84. Map showing the distribution of all sites with prehistoric components at Fort Boggy State Park. 
FIGURE 85. REDACTED

Figure 85. Map showing the distribution of sites with Woodland and/or Late Prehistoric components at Fort Boggy State Park. 
FIGURE 86. REDACTED

Figure 86. Map showing the distribution of all sites with historical components at Fort Boggy State Park. 


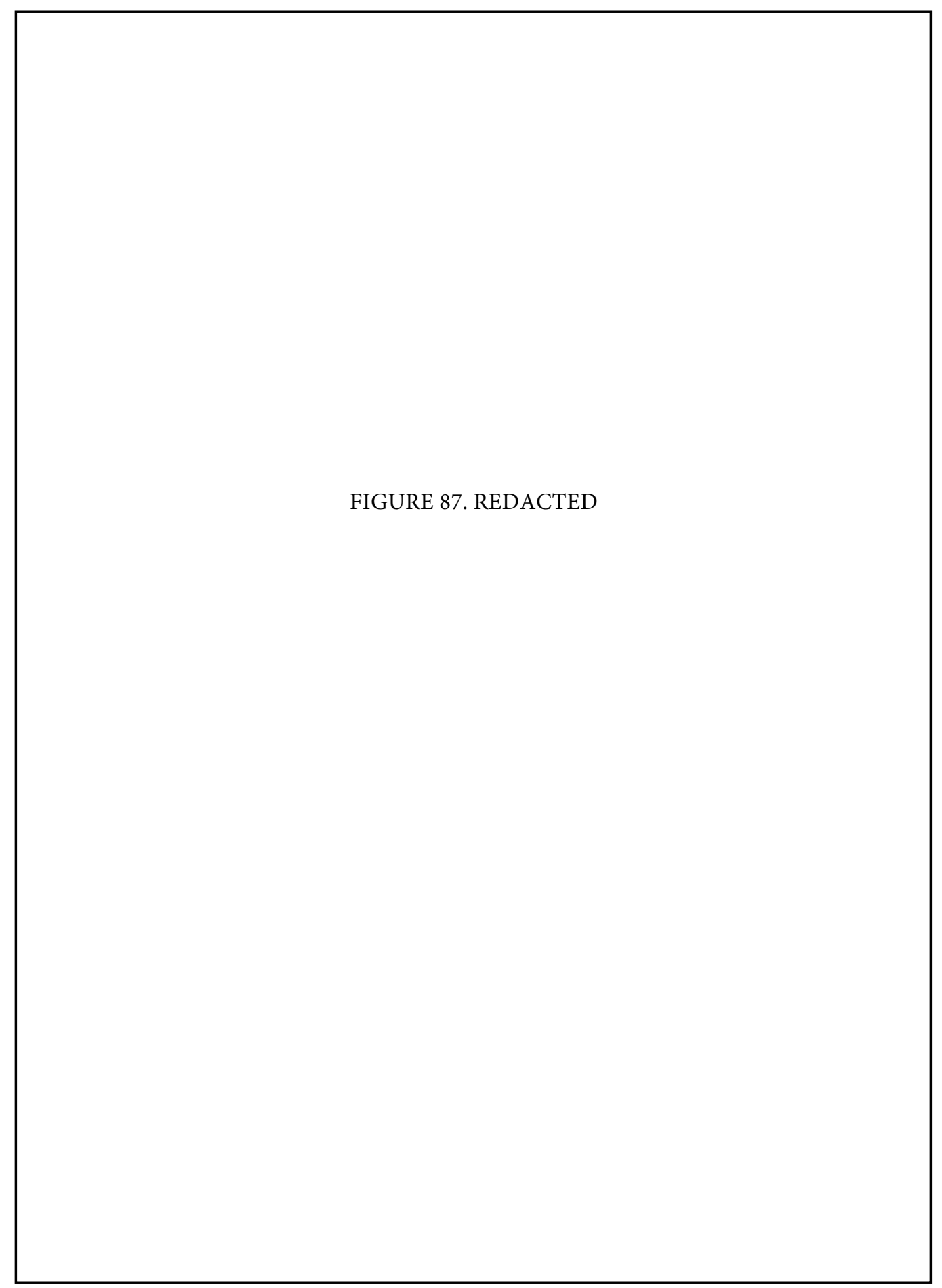

Figure 87. Map showing the distribution of sites with pre-1870 historical components at Fort Boggy State Park. 


\section{Chapter 6}

\section{MANAGEMENT RECOMIMENDATIONS}

\section{National Register of Historic Places Eligibility}

The National Register of Historic Places (NRHP) evaluations of the sites at Fort Boggy State Park are based on two measures: (1) the NRHP criteria of significance (36 CFR Part 60.4), and (2) the integrity of the archaeological deposits. The NRHP criteria apply to districts, sites, buildings, structures, and objects that possess integrity of location, design, setting, materials, workmanship, feelings, and association, and:

A. that are associated with events that have made a significant contribution to the broad patterns of our history; or

B. that are associated with the lives of persons significant in our past; or

C. that embody the distinctive character of a type, period, or method of construction, or that represent the work of a master, or that possess high artistic value, or that represent a significant and distinguishable entity whose components may lack individual distinction; or

D. that have yielded, or may be likely to yield, information important in prehistory or history.

Integrity refers to the "ability of a property to convey its significance....and to retain historic integrity a property will always possess several, and usually most, of the aspects" (Townsend et al. 1993:17). With respect to archaeological resources, integrity is best assessed by ascertaining if sites under consideration have the following characteristics: (1) the archaeological deposits appear contextually intact (Little 2005:117), and features have either been identified, or the potential exists for features to be present; (2) there exists, or the potential exists, for intra-site patterning in features and artifacts; and (3) representative samples are present from undisturbed contexts of artifacts and/or features in different site assemblages, if further investigated. If prehistoric or historical archaeological sites be documented in the project areas that appear to have integrity of content and setting, along with relevant data on settlement location/landform, and the age of the occupation can likely be established, then they will more than likely be able to contribute important information on the prehistory and history of this part of East Central Texas.

Criterion D of the NRHP is the most relevant in the consideration of the Fort Boggy State Park sites because it specifically addresses the important contributions-via the information it can be demonstrated they contain (Little 2005:118)—that prehistoric, multi-component prehistoric-historical sites, and historical sites can make to understanding the native history and American history of the East Central Texas region. Such sites, especially those occupied in historical times, may have the potential, as well, to be eligible for inclusion in the NRHP under Criterion A (36 CFR 60.4a), although a definitive demonstration of research potential is difficult to achieve with archaeological sites known only from survey-level investigations and the excavation of a single $50 \times 50 \mathrm{~cm}$ unit, and minimal archival or historical information. If prehistoric or historical archaeological sites were documented during the archaeological site relocation project that clearly had preserved midden deposits found in the shovel testing (as did three of the prehistoric archaeological sites), discrete archaeological deposits with a range of material of known age, any preserved plant and/or animal remains, and a reasonable likelihood for features to be preserved given their 
depositional context, then such sites would be considered eligible for inclusion in the NRHP under criterion D (36 CFR Part 60.4d).

Finally, prehistoric or historical archaeological sites with poor contextual integrity, a limited artifact assemblage, and as well as extensive disturbances (from such things as timber clear cuts, erosion, road construction, heavy machinery activity, etc.), must be considered ineligible for inclusion in the NRHP because they (1) do not have the potential to contribute to a better understanding of the prehistory or history of the region, and (2) will not add new and important information that would address any pertinent regional research questions or add new information pertinent to regional research problems presented.

Based on the discussion above about integrity and archaeological content/context of the sitesand keeping in mind the limited amount of archaeological investigations that the prehistoric, historic, and prehistoric/historic sites received during this pedestrian survey and shovel testing effort-it is our opinion that none of the sites identified during the Fort Boggy State Park archaeological survey and relocation warrant inclusion in the NRHP at this time. Instead, it is our recommendation that the following 33 sites with prehistoric and/or historical components are of undetermined NRHP eligibility, pending test excavations (along with more extensive archival and historical research on the sites with primary historical archaeological components as well as archival and historical research on the importance of the road cuts and networks of roads within the boundaries of the state park) to determine if they meet any of the criteria specified in 36 CFR Part 60.4 for the NRHP:

$\begin{array}{lll}41 L N 299 & 41 L N 300 & 41 L N 302 \\ 41 L N 303 & 41 L N 304 & 41 L N 306 \\ 41 L N 307 & 41 L N 308 & 41 L N 309 \\ 41 L N 311 & 41 L N 314 & 41 L N 321 \\ 41 L N 322 & 41 L N 323 & 41 L N 324 \\ 41 L N 325 & 41 L N 330 & 41 L N 331 \\ 41 L N 332 & 41 L N 333 & 41 L N 334 \\ 41 L N 335 & 41 L N 340 & 4 l L N 341 \\ 41 L N 343 & 41 L N 345 & 41 L N 355 \\ 41 L N 359 & 41 L N 360 & 41 L N 361 \\ 41 L N 362 & 41 L N 372 & 41 L N 373\end{array}$

Because of their poor contextual integrity, their limited archaeological content and potential, and past disturbances, the remaining 47 recorded archaeological sites at Fort Boggy State Park are considered ineligible for inclusion in the NRHP. It is our opinion that these prehistoric and/or historical sites do not have the potential to contribute to a better understanding of the prehistory or history of East Central Texas or add new and important information that would address pertinent research questions or research problems focusing on the unique character of Texas' Post Oak Savannah archaeology (cf. Fields 1995, 2004; Prikryl 1993). 


\section{State Archeological Landmark Eligibility}

The Criteria for Evaluating Archeological Sites as State Archeological Landmarks (SALs) are listed in Chapter 26.8 of the General Rules of Practice and Procedure (Chapter 26) for the Antiquities Code of Texas. SAL criteria are very similar to those outlined for the NRHP, as archaeological sites should meet the following criteria:

(1) the site has the potential to contribute to a better understanding of the prehistory and/or history of Texas by the addition of new and important information;

(2) the site's archaeological deposits and the artifacts within the site are preserved and intact, thereby supporting the research potential or preservation interests of the site;

(3) the site possesses unique or rare attributes concerning Texas prehistory and/or history;

(4) the study of the site offers the opportunity to test theories and methods of preservation, thereby contributing to new scientific knowledge; and

(5) the high likelihood that vandalism and relic collecting has occurred or could occur, and official landmark designation is needed to insure maximum legal protection, or alternatively further investigations are needed to mitigate the effects of vandalism and relic collecting when the site cannot be protected.

Although all archaeological sites in Fort Boggy State Park are de facto SALs according to Section 191.092 of the Antiquities Code of Texas, a smaller number of these may warrant official designation after their research potential has been evaluated under the previously mentioned General Rules of Practice and Procedure. Our consideration of the SAL eligibility of the 80 known archaeological sites at Fort Boggy State Park is based on Chapter 26.8(1-4). Our determinations are cognizant of the possibility that the Texas Historical Commission and Texas Parks and Wildlife Department may also make a determination of whether or not these site warrant designation under Chapter 26.8(5). With respect to archaeological resources, to have "intact" and preserved archaeological deposits means they have (at the survey and shovel testing level of investigation): (1) the potential for features to be present, and/or features have been identified; (2) there exists, or the potential exists, for intra-site patterning in artifacts and features; and (3) representative samples of artifacts and/or features are present from undisturbed contexts from specific site assemblages and deposits.

In the present set of sites at Fort Boggy State Park, criteria 1 and 2 above are the most relevant because they specifically address the important contributions the sites can make to understanding the history and prehistory of this part of Leon County and East Central Texas. These criteria are also readily employed in site evaluations that are based on the sort of minimal data obtained from archaeological sites identified and documented only through pedestrian survey, shovel testing, and 50 x $50 \mathrm{~cm}$ unit excavations.

In many cases, the eligibility of particular sites for SAL designation cannot be determined with the present limited archaeological information because it is not possible to demonstrate with surface, shovel testing, and $50 \times 50 \mathrm{~cm}$ unit data that they have, or had, information that can contribute to our understanding of human history or prehistory (pre-A.D. 1680) in the region. Without a definitive demonstration-which is difficult to achieve with archaeological sites known only from survey-level investigations-of research 
potential, we can only conclude that their SAL status is undetermined. Our assessments of the SAL eligibility of the prehistoric and historical sites in Forth Boggy State Park are presented in Table 18.

Table 18. State Archeological Landmark (SAL) recommendations for Fort Boggy State Park sites.*

\begin{tabular}{|c|}
\hline SITES RECOMMENDED FOR SAL STATUS BASED ON PREHISTORIC ARCHAEOLOGICAL COMPONENT \\
\hline 4lLN308, $41 \mathrm{LN} 325$ \\
\hline SITES WHERE SAL EVALUATION NEEDED FOR PREHISTORIC ARCHAEOLOGICAL COMPONENT \\
\hline 41LN299, 4 1LN304, 4 lLN32 1, 4 lLN322, 4 lLN323, 41LN340, 41LN34 1, 4 lLN343 \\
\hline SITES NOT RECOMMENDED FOR SAL STATUS BASED ON PREHISTORIC ARCHAEOLOGICAL COMPONENT \\
\hline 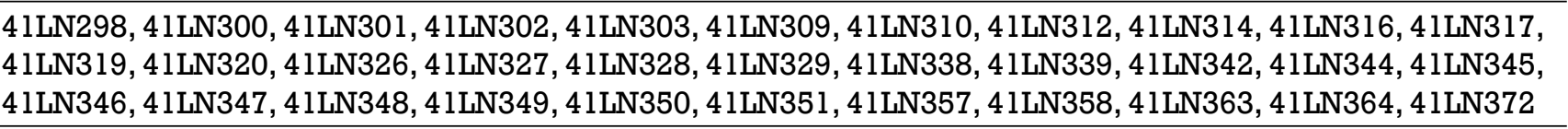 \\
\hline SITES RECOMMENDED FOR SAL STATUS BASED ON HISTORICAL ARCHAEOLOGICAL COMPONENT \\
\hline None at the present time \\
\hline SITES WHERE SAL EVALUATION NEEDED FOR HISTORICAL ARCHAEOLOGICAL COMPONENT \\
\hline 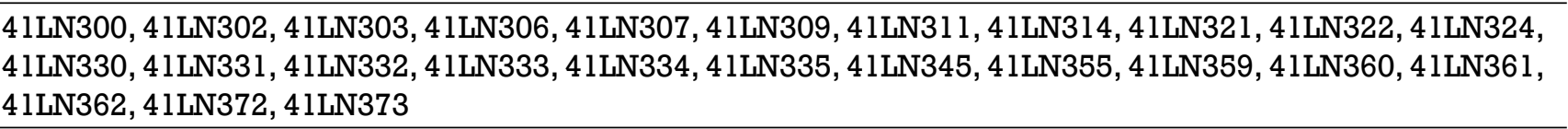 \\
\hline SITES NOT RECOMMENDED FOR SAL STATUS BASED ON HISTORICAL ARCHAEOLOGICAL COMPONENT \\
\hline 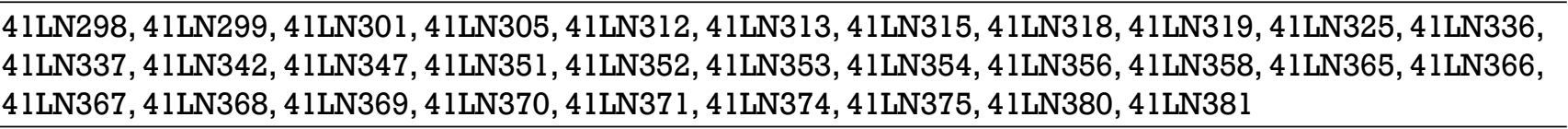 \\
\hline $\begin{array}{l}\text { *since many sites have both prehistoric and historical archaeological components, those that do will be } \\
\text { listed twice in this table. }\end{array}$ \\
\hline
\end{tabular}

The prehistoric archaeological components at 41 LN308 and the Black Finger Tip site (41LN325) have been recommended for SAL designation under criteria 1 and 2 primarily on the basis of the fact that both sites have well preserved midden deposits that are ca. $20 \mathrm{~m}$ in diameter and 59-80 cm thick at $41 \mathrm{LN} 308$ and 80-100 cm+ thick at the Black Finger Tip site (4lLN325). These middens, which apparently accumulated beginning in the Woodland period, and then continued to be occupied in the Late Prehistoric period (e.g., to some time after ca. A.D. 1200), contain animal bone, charred plant remains (Carya sp. nutshell and wood charcoal), burned clay pieces, lithic debris, chipped stone tools, and prehistoric ceramic sherds. These include both sandy paste Goose Creek Plain and later grog- and bone-tempered decorated ceramic wares that share stylistic and technological attributes with East Texas Caddo ceramic wares. The Last Chance Quarry site (4lLN341) also has a midden deposit, but unlike the two aforementioned sites, the midden does not have well-preserved animal bones or charred plant remains. Consequently, it has been placed in the category of prehistoric sites where evaluation of its SAL qualities is warranted (see Table 18).

The prehistoric sites where SAL evaluation is needed (see Table 18), in our opinion, appear to have intact archaeological deposits with the potential for features (based on the recovery of fire-cracked rocks from hot rock cooking features from several of the sites) and intra-site spatial information on cultural activities, particularly the use of local and non-local lithic raw material sources for chipped stone tools, and the manufacture and use of ceramic wares from Woodland and Late Prehistoric occupations. Provided 
that temporally isolable components can be identified during additional archaeological work at each of the above-listed prehistoric sites and prehistoric components, and we know roughly that these sites were occupied from as early as ca. 4000 years B.P. to post-750 years B.P., the investigation of the technological character of the artifact assemblages (and associated features) should provide important insights into the nature of prehistoric habitation across this part of the Post Oak Savannah cultural landscape during at least a 4000 year prehistoric interval, as well as the settlement and long-term use of the Boggy Creek locale by prehistoric groups.

The sites with historical archaeological components at Fort Boggy State Park that warrant further evaluation as SALs (see Table 18) contain evidence for structures (chimney falls or rock foundation piers), yard or trash discard areas, and a relatively abundant material culture record that may be informative about East Central Texas homesteading and cultural adaptations from as early as ca. 1840 to the early twentieth century. They also contain archaeological (and likely as well historical and archival) data about the lives, consumption patterns of material goods, and the migration of Americans in historical times (Groover 2008:11-30, 127-129), essentially contributing to regional studies of rural material life based on archaeological, kinship, and landscape approaches (cf. Brennan 2008, 2009). An appropriate regional research design or historical context should be developed for guiding further investigations of these farmsteads along Boggy Creek and in the Trinity River basin.

\section{Additional Research Needs}

We have identified three additional research needs concerning the better understanding of the archaeological resources at Fort Boggy State Park, and their significance: (1) detailed archival research on contemporaneous historical sites in the Park that may be part of specific communities in the Boggy Creek valley; (2) additional survey with shovel testing in areas that have a high likelihood of containing prehistoric and/or historical sites; and (3) backhoe investigations at a select number of sites with the demonstrated capacity, or the potential, to contain archaeological deposits with research significance, and that have archaeological deposits in deep sand, typically to $100+\mathrm{cm}$ bs.

\section{Archival Research}

Detailed archival research may be warranted on mid nineteenth-early twentieth-century farmstead sites in the Park that may be apparently associated with each other in a community or communities connected by a network of old road cuts and beds, as well as connected by ethnic and kin relationships. The purpose of this research would be to identify the specific occupants and families that may have used the sites during the length of the archaeologically-defined occupations, and to better understand the relative social position of the families and households that may have lived at the sites.

This proposed research would rely on the use of primary materials, particularly deed record and tax information (ad valorem tax records on microfilm at the Texas State Library and Archives) preserved at the Leon County Clerk's office, the Texas General Land Office, and the Texas State Library and Archives. Online resources (such as Heritage Quest ${ }^{\mathrm{TM}}$ Online) may also contain documentation pertinent to these historical archaeological sites, including age, gender, marital status, numbers of children, etc. of the families that may have lived within each of these households. Tax records, along with relevant U.S. Census 
population schedules, and probate records should provide further useful information on the value of the real and personal property held by the various families and households during the estimated periods of site occupations.

\section{Additional Archaeological Survey with Shovel Testing}

Based on the distribution of known prehistoric and historical archaeological sites at Fort Boggy State Park (see Figure 1) that were chosen for use in the past, it is our recommendation that additional survey investigations accompanied by intensive shovel testing, should be conducted in a number of small parcels ( $n=27)$ throughout the Park (Figure 88). These parcels are situated on a range of landforms, with varying distances to Boggy Creek and its floodplain, as well as to certain tributaries, but all occur in settings similar to those settings in the Park where both prehistoric and historical sites have already been identified and recorded.

The work by Corbin et al. (1994:Figures 53-55) at Fort Boggy State Park consisted of extensive survey transects across the Park, but a concentration of shovel testing on located sites (Corbin et al. 1994:Figure 56), not on the survey transects themselves that traversed the Park. The parcels we have identified in Figure 88 that we recommend as warranting new archaeological survey and shovel testing were either in non-site shovel test areas, or in areas that were not shovel-tested in 1992. The shovel test intensity in these non-site shovel test areas that correspond to our recommended survey parcels, was generally low, less than 0.3 to 2 shovel tests per hectare (Corbin et al. 1994:Figure 56). A more extensive survey and shovel testing program would increase the probability that new, and previously unrecorded and overlooked, sites can be found at Fort Boggy State Park. This would complete the inventory of archaeological sites on the Park, but certainly lead to the identification of other sites (beyond those discussed above) that have the potential to contain significant prehistoric and/or historical archaeological deposits.

\section{Backhoe Investigations}

Considering how many prehistoric sites/components at Fort Boggy State Park have archaeological deposits deeper than 80-100 cm bs (see Table 17), before final determinations of SAL or NRHP eligibility are made for those with an undetermined SAL or NRHP eligibility, backhoe trench investigations may be warranted for a sample of the sites with deep sands. The sites in question include $41 \mathrm{LN} 321$, the Sweetgum site (4lLN323), the Karma Ridge site (4lLN340), the Last Chance Quarry site (4lLN341), and the Fern Slope site (41LN343).

These backhoe trench investigations are important to do at Fort Boggy State Park sites for two principal archaeological reasons: (1) to ascertain and clarify the depth, thickness, and depositional context of deep sandy sediments that may contain deep artifact-bearing sediments and buried features; and (2) to contribute archaeological and geoarchaeological information from Fort Boggy State Park on the research issue of "whether prehistoric sites can occur in a primary context buried within the so-called sandy mantle" (Crawford and Nordt 2001:17; see also Lohse and Bousman 2006). Several competing models have been proposed to account for the origins of the sandy mantle deposits and attempt to explain the occurrence of archaeological materials buried in them (Lohse and Bousman 2006:60-63). These alternatives have implications for interpreting the depositional integrity and research potential of sandy mantle sites from more than shovel testing and $50 \times 50 \mathrm{~cm}$ units that can only penetrate to $100 \mathrm{~cm}$ bs (and are rarely likely to encounter features because the spatial area they can investigate is so limited), and bear on the likely research significance of any sandy mantle sites at Fort Boggy State Park. 
FIGURE 88. REDACTED

Figure 88. Areas recommended for additional archaeological survey investigations at Fort Boggy State Park. 
These proposed backhoe trench investigations could consist of the controlled excavation of a series of 8-10 m long backhoe trenches (4-5 per site) at the selected sites, perhaps in 10-20 cm thick levels, to the basal clay. The trenches would be used to prospect for features and/or buried concentrations of prehistoric archaeological remains, both by examining the trench profiles as well as sampling a regular proportion of the trench level sediments for artifacts, fire-cracked rock, charred nutshells, etc. The presence, type, and approximate depth of archaeological remains in the trenches could be recorded for each trench, but the primary goal would be to determine if the sites contained intact cultural features, intact cultural features with preserved plant and/or animal remains for radiocarbon dating, and/or buried archaeological deposits with discrete concentrations of artifacts from one occupation. 


\section{End Notes}

1. The sites to be evaluated for NRHP and SAL eligibility at Fort Boggy State Park in the 2010 work do not include 4lLN427 and 4lLN428, both first recorded during a 1997 seismic survey of receiver lines and shot lines within the boundaries of the Park (Corbin 1997). 



\section{References}

Adams, William H.

2002 Machine Cut Nails and Wire Nails: American Production and Use for Dating 19th-century and Early 20th-Century Sites. Historical Archaeology 36(4):66-88.

Aten, Lawrence E. and Charles N. Bollich

2002 Late Holocene Settlement in the Taylor Bayou Drainage Basin: Test Excavations at the Gaulding Site (41JF27), Jefferson County, Texas. Studies in Archeology 40, Texas Archeological Research Laboratory, The University of Texas at Austin, and Special Publication No. 4, Texas Archeological Society, San Antonio.

Banks, Larry

1990 From Mountain Peaks to Alligator Stomachs: A Review of Lithic Sources in the Trans-Mississippi South, the Southern Plains, and Adjacent Southwest. Memoir No. 4. Oklahoma Anthropological Society, Norman.

Bousman, C. Britt

1998 Paleoenvironmental Change in Central Texas: The Palynological Evidence. Plains Anthropologist 43(164):201-219.

Brantley, W. F.

1975 A Collector's Guide to Ball Jars. Rosemary Humbert Martin, Muncie, Illinois.

Brennan, Mary Z.

2008 Reconstructing the Genealogical Landscape: Kinship and Settlement along Moccasin and Indian Creeks, Pope County, Arkansas. Arkansas Historical Quarterly 57(4):386-397.

2009 Sense of Place: Reconstructing Community through Archeology, Oral History, and GIS. Ph.D. dissertation, Department of Anthropology, University of Arkansas, Fayetteville.

Bronk Ramsey, C.

2009 Bayesian analysis of radiocarbon dates. Radiocarbon 51(1):337-360.

Bruseth, James E. and William A. Martin (editors)

1987 The Bird Point Island and Adams Ranch Sites: Methodological and Theoretical Contributions to North Central Texas Archaeology. Richland Creek Technical Series Volume II. Archaeology Research Program, Institute for the Study of Earth and Man, Southern Methodist University, Dallas.

Bruseth, James E. and Randall W. Moir (editors)

1987 Introduction to the Richland Creek Archaeological Project, Environmental Background and Cultural Setting. Richland Creek Technical Series Volume I. Archaeology Research Program, Institute for the Study of Earth and Man, Southern Methodist University, Dallas. 
Bureau of Economic Geology

1968 Geologic Atlas of Texas, Palestine Sheet. Bureau of Economic Geology, The University of Texas at Austin.

Corbin, James E.

1996 Archaeological Survey of a Proposed Recreation Facilities Construction Project in Fort Boggy State Park, Leon County, Texas. Archaeological Survey Report No. 96-1 1. James E. Corbin, Nacogdoches.

1997 Cultural Resource Assessment of a Seismographic Project in Fort Boggy State Park, Leon County, Texas. Archaeological Survey Report No. 97-2. James E. Corbin, Nacogdoches.

Corbin, James E., Jeffrey M. Williams, Victor J. Galan, and Rebecca St. John

1994 Cultural Resource Survey of Fort Boggy State Park, Leon County, Texas. Texas Parks and Wildlife Department, Austin.

Crawford, C. A. and Lee C. Nordt

2001 Geoarchaeology. In Camp Maxey III:Archaeological Testing of 23 Prehistoric Sites, Lamar County, Texas, by Richard B. Mahoney, pp. 12-18. Archaeological Survey Report No. 314. Center for Archaeological Research, The University of Texas at San Antonio.

Diggs Jr., George M., Barney L. Lipscomb, Monique D. Reed, and Robert J. O'Kennon

2006 Illustrated Flora of East Texas, Volume One: Introduction, Pteridophytes, Gymnosperms, and Monocotyledons. Sida, Botanical Miscellany, No. 26. Botanical Research Institute of Texas, Fort Worth.

Ellis, Linda W.

2010 Prehistoric Ceramics of the Gulf Coast. In Regional Summaries of Prehistoric and Early Historic Ceramics in Texas for the Council of Texas Archeologists, assembled and edited by Linda W. Ellis and Timothy K. Perttula, pp. 42-57. Council of Texas Archeologists, accessed on April 17, 2011, at http://www.counciloftexasarcheologists.org/index.php?option=com content\&task=view\&id=87\&l temid $=94$.

Fields, Ross C.

1995 The Archaeology of the Post Oak Savannah of East Central Texas. Bulletin of the Texas Archeological Society 66:301-330.

1998 Why We Don't Know Much about the Archaic Period in Northeast Texas. Journal of Northeast Texas Archaeology 11:96-99.

2004 The Archeology of the Post Oak Savanna of East-Central Texas. In The Prehistory of Texas, edited by Timothy K. Perttula, pp. 347-369. Texas A\&M University Press, College Station.

Fields, Ross C., L. Wayne Klement, C. Britt Bousman, Steve A. Tomka, Eloise F. Gadus, and Margaret A. Howard 1991 Excavations at the Bottoms, Rena Branch, and Moccasin Springs Sites, Jewett Mine Project, Freestone and Leon Counties, Texas. Reports of Investigations No. 82. Prewitt and Associates, Inc., Austin. 
Foster, William C.

2008 Historic Native Peoples of Texas. University of Texas Press, Austin.

Gadus, E. Frances, Jennifer K. McWilliams, and Ross C. Fields

2002 Data Recovery Excavations at the McGuire's Garden Site (41FT425), Jewett Mine, Freestone County, Texas. Reports of Investigations No. 134. Prewitt and Associates, Inc., Austin.

Goode, Glenn T.

2002 The Anthon Site: A Prehistoric Encampment in Southern Uvalde County, Texas. Report 38.

Environmental Affairs Division, Archeological Studies Program, Texas Department of Transportation, Austin.

Godden, Geoffrey A.

1964 Encyclopaedia of British Pottery and Porcelain Marks. Barrie \& Jenkins, London.

Greer, Georgeanna H.

1981 American Stoneware: The Art and Craft of Utilitarian Pottery. Schiffer Publishing Ltd., Exton, Pennsylvania.

Groover, Mark D.

2008 The Archaeology of North American Farmsteads. University Press of Florida, Gainesville.

Hunter, Robert R. Jr. and George L. Miller

1994 English Shell-edged Earthenware. Antiques CXLV (No. 3):432-443.

2009 Suitable for Framing: Decorated Shell-Edge Earthenware. Early American Life (August):8-19.

Jennings, Thomas A.

2008 San Patrice: An Example of Late Paleoindian Adaptive Versatility in South-Central North America. American Antiquity 73(3):539-559.

Lebo, Susan A.

1987 Local Utilitarian Stonewares: A Diminishing Artifact Category. In Historic Buildings, Material Culture, and People of the Prairie Margin: Architecture, Artifacts, and Synthesis of Historic Archaeology, edited by David H. Jurney and Randall W. Moir, pp. 121-142. Volume V. Archaeology Research Program, Institute for the Study of Earth and Man, Southern Methodist University, Dallas.

Little, Barbara J.

2005 The U.S. National Register of Historic Places and the shaping of archaeological significance. In Heritage of value, Archaeology of Renown: Re-shaping Archaeological Assessment and Significance, edited by Clay Mathers, T. Darvill, and Barbara J. Little, pp. 114-124. University Press of Florida, Gainesville.

Lockhart, Bill, Pete Schultz, Carol Serr, and Bill Lindsey

2010 The Dating Game-The Owens Bottle Co. Bottles and Extras 21:50-62. 
Lohse, Jon C. and C. Britt Bousman

2006 National Register Evaluation of Eight Sites at Camp Swift Army National Guard Training Center, Bastrop County, Texas: Swift V. Archaeological Studies Report No. 8. Center for Archaeological Studies, Texas State University-San Marcos.

Mainfort, Robert C. and James M. Davidson (editors)

2006 Two Historic Cemeteries in Crawford County, Arkansas. Research Series No. 62. Arkansas Archeological Survey, Fayetteville.

Majewski, Teresita and Michael J. O'Brien

1987 The Use and Misuse of Nineteenth-Century English and American Ceramics in Archaeological Analysis. In Advances in Archaeological Method and Theory, Volume 1 1, edited by Michael B. Schiffer, pp. 97-209. Academic Press, Inc., New York.

McGregor, Daniel E. and James E. Bruseth (editors)

1987 Hunter-Gatherers of the Prairie Margin: Summary of the Prehistoric Archaeological Record. Richland Creek Technical Series Volume III. Archaeology Research Program, Institute for the Study of Earth and Man, Southern Methodist University, Dallas.

Meissner, Barbara A.

1997 Making the Man: Remains of Clothing Recovered from the Alamodome Project. In Archaeology at the Alamodome: Investigations of a San Antonio Neighborhood in Transition, Volume III: Artifacts and Special Studies, edited by Anne A. Fox, Marcie Renner, and Robert J. Hard, pp. 119-164. Archaeological Survey Report No. 238. Center for Archaeological Research, The University of Texas at San Antonio.

Moir, Randall W.

1987 Socioeconomic and Chronometric patterning of Window Glass. In Historic Buildings, Material Culture, and People of the Prairie Margin: Architecture, Artifacts, and Synthesis of Historic Archaeology, edited by David H. Jurney and Randall W. Moir, pp. 73-81. Volume V. Archaeology Research Program, Institute for the Study of Earth and Man, Southern Methodist University, Dallas.

1988 Windows and Window Glass. In Historic Farming on the Hogwallow Prairies: Ethnoarchaeological Investigations of the Mountain Creek Area, North Central Texas, Volume II, compiled by David H. Jurney, Susan A. Lebo, and Melissa M. Green, pp. 263-272. Archaeology Research Program, Institute for the Study of Earth and Man, Southern Methodist University, Dallas.

National Park Service

2010 El Camino Real de los Tejas National Historic Trail, Draft Comprehensive Management Plan/ Environmental Assessment. National Trails Intermountain Region, National Park Service, U.S. Department of the Interior, Santa Fe.

Neitsch, C. L., J. J. Castille, and M. R. Jurena

1989 Soil Survey of Leon County, Texas. United States Department of Agriculture, Soil Conservation Service, in cooperation with the Texas Agricultural Experiment Station and the Texas State Soil and Water Conservation Board. U.S. Government Printing Office, Washington D.C. 
Peck, Jay, James T. Abbott, Charles D. Frederick, Patrick L. O'Neill, and Abby C. Treece

1996 Cultural Resource Survey of Area A of the Jewett Mine, Freestone County, Texas. TRC Mariah Associates, Austin.

Perttula, Timothy K.

2004 The Prehistoric and Caddoan Archeology of the Northeast Texas Pineywoods. In The Prehistory of Texas, edited by Timothy K. Perttula, pp. 370-407. Texas A\&M University, College Station.

2009 Caddo Ceramics from two Sites in the Post Oak Savanna, Leon County, Texas. La Tierra 35(4):82-84.

Perttula, Timothy K. (editor)

2008 Lake Naconiche Archeology, Nacogdoches County, Texas: Results of the Data Recovery Excavations at Five Prehistoric Archeological Sites. 2 Vols. Report of Investigations No. 60. Archeological \& Environmental Consultants, LLC, Austin.

Perttula, Timothy K. and Bo Nelson

2003 Archeological Survey along the Lake Bob Sandlin Shoreline, Camp, Franklin, and Titus Counties, Texas. Report of Investigations No. 46. Archeological \& Environmental Consultants, LLC, Austin and Pittsburg.

2006 Test Excavations at Three Caddo Sites at Mission Tejas State Park, Houston County, Texas. Report of Investigations No. 76. Archeological \& Environmental Consultants, LLC, Austin.

Prikryl, Daniel J.

1993 Introduction. In Archeology in the Eastern Planning Region, Texas: A Planning Document, edited by Nancy A. Kenmotsu and Timothy K. Perttula, pp. 191-204. Cultural Resource Management Report 3. Department of Antiquities Protection, Austin.

Reimer, P. J., Baillie, M. G. L., Bard, E., Bayliss, A., Beck, J. W., Blackwell, P. G., Bronk Ramsey, C., Buck, C. E., Burr, G. S., Edwards, R. L., Friedrich, M., Grootes, P. M., Guilderson, T. P., Hajdas, I., Heaton, T. J., Hogg, A. G., Hughen, K. A., Kaiser, K. F., Kromer, B., McCormac, F. G., Manning, S. W., Reimer, R. W., Richards, D. A., Southon, J. R., Talamo, S., Turney, C. S. M., van der Plicht, J., and Weyhenmeyer, C. E.

2009 IntCal09 and Marine09 radiocarbon age calibration curves, 0-50,000 years cal BP. Radiocarbon 51(4): 1111-1150.

Ricklis, Robert A.

2004 The Archeology of the Native American Occupation of Southeast Texas. In The Prehistory of Texas, edited by Timothy K. Perttula, pp. 181-202. Texas A\&M University Press, College Station.

Rogers, R.

1991 National Register Testing of Nine Prehistoric Sites at the Gibbons Creek Third Five-Year Mine Area, Grimes County, Texas. Document No. 900500. EHA, Austin.

1993 National Register Testing of Six Archaeological Sites in the GCLM IV and GCLMV Mine Permit Areas, Grimes County, Texas. Document No. 920937. EHA, Austin.

1994 Excavations at Site 41 GM224 in the Gibbons Creek Lignite Mine Permit 38A Area, Grimes County, Texas. Document No. 930476. EHA, Austin 
Samford, Patricia M.

2000 Response to a Market: Dating English Underglaze Transfer-Printed Wares. In Approaches to Material Culture Research for Historical Archaeologists, compiled by David R. Brauner, pp. 56-85. $2^{\text {nd }}$ Edition. The Society for Historical Archaeology, California, Pennsylvania.

Shafer, Harry J.

2007 People of the Prairie: A Possible Connection to the Davis Site Caddo. Research module published on-line by the Council of Texas Archeologists, Prairiecaddomodule.pdf.

2011 Boxed Springs Mound Site (41UR30) Lithic Analysis. In Archaeological and Archaeogeophysical Investigations at an Early Caddo Mound Center in the Sabine River Basin of East Texas, assembled by Timothy K. Perttula, pp. 78-111. Special Publication No. 15. Friends of Northeast Texas Archaeology, Austin and Pittsburg.

Shafer, Harry J. and Mark Walters

2010 The Browning Site (41SM195A) Lithics: Considering Patterns of Identity and Interaction Through Lithic Analysis. Bulletin of the Texas Archeological Society 81:127-151.

Society for Historical Archaeology

2010 Historic Glass Bottle Identification \& Information Website. http://www.sha.org/bottle/index.htm. Accessed online, July 2, 2010.

Story, Dee Ann

1990 Culture History of the Native Americans. In The Archeology and Bioarcheology of the Gulf Coastal Plain, by Dee Ann Story, Janice A. Guy, Barbara A. Burnett, Martha D. Freeman, Jerome C. Rose, D. Gentry Steele, Ben W. Olive, and Karl J. Reinhard, pp. 163-366. 2 Vols. Research Series No. 38. Arkansas Archeological Survey, Fayetteville.

Suhm, Dee Ann and Edward B. Jelks (editors)

1962 Handbook of Texas Archeology: Type Descriptions. Special Publication No. 1, Texas Archeological Society, and Bulletin No. 4, Texas Memorial Museum, Austin.

Teltser, Patrice A.

1993 An Analytic Strategy for Studying Assemblage-Scale Ceramic Variation: A Case Study from Southeast Missouri. American Antiquity 58(3):530-543.

Thoms, Alston V.

2008a Ancient Savannah Roots of the Carbohydrate Revolution in South-Central North America. Plains Anthropologist 53(205):121-136.

2008b The fire stones carry: Ethnographic records and archaeological expectations for hot-rock cookery in western North America. Journal of Anthropological Archaeology 27(4):443-460.

Thoms, Alston V. (editor)

1997 The Upper Keechi Creek Archaeological Project: Survey and Test Excavations at the Keechi Creek Wildlife Management Area, Leon County, Texas. Technical Report No. 3. Center for Environmental Archaeology, Texas A\&M University, College Station. 
Townsend, Jan, John H. Sprinkle, Jr., and John Knoerl

1993 Guidelines for Evaluating and Registering Historical Archeological Sites and Districts. National

Register Bulletin 36. U.S. Department of the Interior, National Park Service, Interagency Resources

Division, Washington, D.C.

Turner, Ellen Sue and Thomas R. Hester

1999 A Field Guide to Stone Artifacts of Texas Indians. Gulf Publishing, an imprint of Rowan \& Littlefield

Publishers, Inc., Lanham, Maryland.

Wells, Tom

2000 Nail Chronology: The Use of Technologically Derived Features. In Approaches to Material Culture

Research for Historical Archaeologists, compiled by David R. Brauner, pp. 318-339. 2nd Edition. The Society for Historical Archaeology, California, Pennsylvania.

Zapata, Jose E.

1997 Alamodome and Abroad: A Composite Inquiry on Toy Marbles. In Archaeology at the Alamodome: Investigations of a San Antonio Neighborhood in Transition, Volume III: Artifacts and Special Studies, edited by Anne A. Fox, Marcie Renner, and Robert J. Hard, pp. 100-1 18. Archaeological Survey Report No. 238. Center for Archaeological Research, The University of Texas at San Antonio. 



\section{Appendix 1}

\section{Shovel Test Descriptions}

ST 1

ST 2

ST 3

ST 4

ST 5

ST 6

ST 7

ST 8

ST 9

ST 10

ST 11

ST 12

ST 13

ST 14

ST 15

ST 16

ST 17

ST 18

ST 19

ST 20

ST 21

ST 22

ST 23

ST 24

ST 25

ST 26

ST 27

ST 28

ST 29

ST 30

0-100 cm+, yellowish-brown fine sandy loam

$0-100 \mathrm{~cm}+$, yellowish-brown fine sandy loam

0-100 cm+, yellowish-brown fine sandy loam

0-95 cm, yellowish-brown fine sandy loam; 95-100 cm+, yellowish-brown sandy clay

0-97 cm, yellowish-brown fine sandy loam; $97-100 \mathrm{~cm}+$, yellowish-brown sandy clay (fine sandy loam zone contains prehistoric artifacts, 4lLN350)

0-100 cm+, yellowish-brown fine sandy loam

0-5 cm, dark grayish-brown sandy loam; 5-100 cm+, yellowish-brown fine sandy loam

0-50 cm, yellowish-brown fine sandy loam; 50-55 cm+, brownish-yellow sandy clay

0-38 cm, yellowish-brown fine sandy loam; 38-45 cm+, brownish-yellow sandy clay

0-17 cm, brown fine sandy loam; 17-102 cm+, yellowish-brown fine sandy loam

0-17 cm, brown fine sandy loam; 17-89 cm, yellowish-brown fine sandy loam; 89-90 cm+, yellowish-brown sandy clay

0-14 cm, brown fine sandy loam; 14-103 cm+, yellowish-brown fine sandy loam

0-9 cm, brown fine sandy loam; 9-102 cm+, yellowish-brown fine sandy loam

0-19 cm, brown fine sandy loam; 19-103 cm+, yellowish-brown fine sandy loam

0-101 cm+, yellowish-brown fine sandy loam

0-30 cm, brown fine sandy loam; 30-70 cm, yellowish-brown fine sandy loam; 70-100 cm+, pale brown fine sandy loam

0-20 cm, brown fine sandy loam; 20-50 cm, yellowish-brown fine sandy loam; 50-100 cm+, pale brown fine sandy loam

0-100 cm+, yellowish-brown sandy loam (prehistoric artifacts in the sandy loam zone, 4lLN351)

0-15 cm, brown fine sandy loam; 15-103 cm+, yellowish-brown fine sandy loam

0-13 cm, brown fine sandy loam; 13-100 cm+, yellowish-brown fine sandy loam

0-20 cm, yellowish-brown fine sandy loam; $20-25 \mathrm{~cm}+$, yellowish-brown sandy clay

0-50 cm, yellowish-brown fine sandy loam; $50-53 \mathrm{~cm}+$, yellowish-red clay

0-11 cm, brown sandy loam; 11-100 cm+, yellowish-brown fine sandy loam

0-48 cm, brown sandy loam; 48-83 cm, yellowish-brown sandy loam; $83 \mathrm{~cm}+$, yellowishred clay

0-12 cm, brown fine sandy loam; 12-102 cm+, yellowish-brown fine sandy loam

0-104 cm+, yellowish-brown fine sandy loam

0-12 cm, brown fine sandy loam; 12-109 $\mathrm{cm}+$, yellowish-brown fine sandy loam

0-24 cm, brown sandy loam; 24-52 cm, yellowish-brown sandy loam; 52-55 cm+, yellowish-red clay (prehistoric artifacts in the yellowish-brown sandy loam zone, 4lLN349)

0-5 cm, dark grayish-brown sandy loam; 5-27 cm, brown sandy loam; 27-30 cm+, yellowish-red clay

0-29 cm, brown sandy loam; 29-80 cm, yellowish-brown sandy loam; 80-83 cm+, yellowish-red clay 
ST 31

ST 32

ST 33

ST 34

ST 35

ST 36

ST 37

ST 38

ST 39

ST 40

ST 41

ST 42

ST 43

ST 44

ST 45

ST 46

ST 47

ST 48

ST 49

ST 50

ST 51

ST 52

ST 53

ST 54

ST 55

ST 56

ST 57

ST 58

ST 59

ST 60

ST 61

ST 62

0-85 cm, yellowish-brown sandy loam; $85 \mathrm{~cm}+$, yellowish-red clay

0-100 $\mathrm{cm}+$, yellowish-brown sandy loam

0-100 cm+, yellowish-brown sandy loam

$0-100 \mathrm{~cm}+$, yellowish-brown sandy loam

0-100 cm+, yellowish-brown sandy loam

0-113 cm+, yellowish-brown sandy loam

0-100 cm+, yellowish-brown sandy loam

0-15 cm, brown sandy loam; 15-100 cm+, yellowish-brown sandy loam

0-73 cm, yellowish-brown sandy loam; $73 \mathrm{~cm}+$, yellowish-red clay (prehistoric artifacts from the sandy loam zone, 4lLN349)

0-14 cm, brown sandy loam; 14-71 cm, yellowish-brown sandy loam; $71 \mathrm{~cm}+$, yellowishbrown sandy clay

0-10 cm, brown sandy loam; 10-100 cm+, yellowish-brown sandy loam

0-13 cm, brown sandy loam; 13-101 cm+, yellowish-brown sandy loam

0-12 cm, brown sandy loam; $12-50 \mathrm{~cm}$, yellowish-brown sandy loam; 50-53 cm+, yellowish-red clay

0-24 cm, brown sandy loam; 24-80 cm, yellowish-brown sandy loam; 80-84 cm+, yellowish-red clay

0-101 cm+, yellowish-brown sandy loam

0-22 cm, brown sandy loam; 22-106 cm+, yellowish-brown sandy loam

0-14 cm, brown sandy loam; 14-45 cm, yellowish-brown sandy loam; 45-48 cm+, yellowish-red clay

0-14 cm, brown sandy loam; 14-44 cm, yellowish-brown sandy loam; 44-46 cm+, yellowish-red clay

0-85 cm, yellowish-brown sandy loam; 85-89 cm+, yellowish-red clay

0-17 cm, brown sandy loam; 17-20 cm+, yellowish-red clay

0-8 cm, dark grayish-brown sandy loam; 8-100 cm+, yellowish-brown sandy loam (prehistoric artifacts in the lower sandy loam zone, 4lLN348)

0-100 cm+, yellowish-brown sandy loam

0-103 cm+, yellowish-brown sandy loam (prehistoric artifacts in the sandy loam zone, 4lLN348)

0-12 cm, brown sandy loam; 12-45 cm, yellowish-brown sandy loam; 45-47 cm+, yellowish-red clay

0-12 cm, brown sandy loam; 12-100 cm+, yellowish-brown sandy loam

0-20 cm, yellowish-brown sandy loam; $20-23 \mathrm{~cm}+$, yellowish-red clay

0-14 cm, brown sandy loam; 14-50 cm, yellowish-brown sandy loam; 50-53 cm+

0-48 cm, yellowish-brown sandy loam; 48-52 cm+, yellowish-brown sandy clay

0-100 cm+, yellowish-brown sandy loam

0-40 cm, yellowish-brown sandy loam; $40 \mathrm{~cm}+$, yellowish-brown sandy clay

0-7 cm, brown sandy loam; 7-54 cm, yellowish-brown sandy loam; 54-56 cm+, yellowishbrown sandy clay

0-9 cm, brown sandy loam; 9-39 cm, yellowish-brown sandy loam; 39-41 cm+, yellowishbrown sandy clay 

brown sandy clay

ST 64

ST 65

ST 66

ST 67

ST 68

ST 69

ST 70

ST 71

ST 72

ST 73

ST 74

ST 75

ST 76

ST 77

ST 78

ST 79

ST 80

ST 81

ST 82

ST 83

ST 84

ST 85

ST 86

ST 87

ST 88

0-32 cm, yellowish-brown sandy loam; 32-34 cm+, yellowish-brown sandy clay

0-20 cm, brown sandy loam; 20-60 cm, yellowish-brown sandy loam; 60-63 cm+, yellowish-brown sandy clay (yellowish-brown sandy loam zone contains historical artifacts, 4lLN324)

0-19 cm, brown sandy loam; 19-65 cm, yellowish-brown sandy loam; 65-67 cm+, yellowish-brown sandy clay (brown sandy loam zone contains historical artifacts, 4lLN324)

0-19 cm, brown sandy loam; 19-55 cm, yellowish-brown sandy loam; 55-57 cm+, yellowish-brown sandy clay

0-11 cm, brown sandy loam; 11-60 cm, yellowish-brown sandy loam; 60-62 cm+, yellowish-brown sandy clay

0-15 cm, brown sandy loam; 15-40 cm, yellowish-brown sandy loam; 40-43 cm+, yellowish-brown sandy clay

0-18 cm, brown sandy loam; 18-45 cm, yellowish-brown sandy loam; 45-48 cm+, yellowish-brown sandy clay

0-30 cm, brown sandy loam; 30-45 cm, yellowish-brown sandy loam; $45-47 \mathrm{~cm}+$, yellowish-brown sandy clay (the brown and yellowish-brown sandy loam zones contain historical artifacts, 4lLN324)

0-40 cm, brown sandy loam; 40-63 cm+, yellowish-brown sandy loam (the brown and yellowish-brown sandy loam zones contain historical artifacts, 4lLN324)

0-16 cm, brown sandy loam; 16-40 cm, yellowish-brown sandy loam; 40-43 cm+, yellowish-brown sandy clay (brown sandy loam zone contains historical artifacts, 4lLN324)

0-40 cm, yellowish-brown sandy loam; 40-4l cm+, yellowish-brown sandy clay (yellowishbrown sandy loam zone contains historical artifacts, 4lLN324)

0-16 cm, yellowish-brown sandy loam; 16-17 cm+, yellowish-brown sandy clay

0-35 cm, yellowish-brown sandy loam; 35-37 cm+, yellowish-brown sandy clay

0-13 cm, yellowish-brown sandy loam; $13-14 \mathrm{~cm}+$, yellowish-red clay

0-60 cm, very dark gray fine sandy loam midden; 60-64 cm+, yellowish-red clay (prehistoric artifacts are present in the fine sandy loam midden zone, 4lLN34l)

0-73 cm, very dark gray sandy loam midden; 73-75 cm+, yellowish-red clay (prehistoric artifacts are present in the sandy loam midden zone, $41 \mathrm{LN} 341$ )

0-8 cm, dark grayish-brown sandy loam; 8-15 cm+, yellowish-red clay

0-5 cm, dark grayish-brown sandy loam; 5-10 cm+, yellowish-red clay

0-10 cm, dark grayish-brown sandy loam; 10-15 cm+, yellowish-red clay

0-100 cm+, yellowish-brown sandy loam (sandy loam zone contains prehistoric artifacts, 4lLN341)

0-102 cm+, yellowish-brown sandy loam

0-80 cm, yellowish-brown sandy loam; $80-83 \mathrm{~cm}+$, yellowish-red clay

0-20 cm, yellowish-brown sandy loam; $20-28 \mathrm{~cm}+$, yellowish-brown sandy clay

0-50 cm+, yellowish-brown sandy loam (sandy loam zone contains prehistoric artifacts, $41 \mathrm{LN} 341)$

0-38 cm, yellowish-brown sandy loam; 38-40 cm+, yellowish-brown sandy clay 
ST 89

ST 90

ST 91

ST 92

ST 93

ST 94

ST 95

ST 96

ST 97

ST 98

ST 99

ST 100

ST 101

ST 102

ST 103

ST 104

ST 105

ST 106

ST 107

ST 108

ST 109

ST 110

ST 111

ST 112

ST 113

ST 114

ST 115

ST 116

ST 117

ST 118
0-31 cm, yellowish-brown sandy loam; $31-34 \mathrm{~cm}+$, yellowish-brown sandy clay 0-106 cm+, dark grayish-brown sandy loam (sandy loam zone contains prehistoric artifacts, $41 \mathrm{LN} 341$ )

0-15 cm, yellowish-brown sandy loam; $15-20 \mathrm{~cm}+$, yellowish-brown sandy clay 0-77 cm, yellowish-brown sandy loam; 77-80 cm+, yellowish-brown sandy clay 0-12 cm, dark grayish-brown sandy loam; 12-35 cm, yellowish-brown sandy loam; 35-38 $\mathrm{cm}+$, yellowish-red clay (prehistoric artifacts in the sandy loam zones, 4lLN34l)

0-12 cm, dark grayish-brown sandy loam; 12-42 cm, yellowish-brown sandy loam; 42-44 $\mathrm{cm}+$, yellowish-red clay

0-9 cm, dark grayish-brown sandy loam; 9-48 cm, yellowish-brown sandy loam; 48-49

$\mathrm{cm}+$, yellowish-red clay (prehistoric artifacts in the dark grayish-brown sandy loam zone, 41LN341)

0-32 cm, dark grayish-brown sandy loam; $32-41 \mathrm{~cm}$, yellowish-brown sandy loam; 41-42 $\mathrm{cm}+$, yellowish-red clay

0-16 cm, yellowish-brown sandy loam; $16-17 \mathrm{~cm}+$, yellowish-red clay

0-30 cm, yellowish-brown sandy loam; 30-32 cm+, yellowish-red clay

0-20 cm, brown sandy loam; 20-23 cm+, yellowish-red clay (prehistoric artifacts in the sandy loam zone, $41 \mathrm{LN} 341$ )

0-6 cm, very dark grayish-brown sandy loam; $6-43 \mathrm{~cm}$, dark grayish-brown sandy loam; $43 \mathrm{~cm}+$, yellowish-red clay (prehistoric artifacts in the dark grayish-brown sandy loam zone, $41 \mathrm{LN} 341$ )

0-38 cm, dark grayish-brown sandy loam; 38-62 cm, brown sandy loam; $62 \mathrm{~cm}+$, yellowish-red clay (prehistoric artifacts in the dark grayish-brown sandy loam zone, 41LN341)

0-15 cm, brown sandy loam; 15-40 cm, yellowish-brown sandy loam; $40 \mathrm{~cm}+$, yellowishred clay

0-56 cm, brown sandy loam; $56 \mathrm{~cm}+$, yellowish-red clay

0-15 cm, grayish-brown sandy loam; 15-100 cm+, yellowish-brown sandy loam

0-100 cm+, yellowish-brown sandy loam

0-90 cm, yellowish-brown sandy loam; 90-101 cm+, yellowish-brown sandy clay (prehistoric artifacts in the sandy loam zone, 4lLN342)

0-100 cm+, yellowish-brown sandy loam

0-52 cm, yellowish-brown sandy loam; 52-60 cm+, yellowish-brown sandy clay

0-100 cm+, yellowish-brown sandy loam

0-102 $\mathrm{cm}+$, yellowish-brown sandy loam

0-103 cm+, yellowish-brown sandy loam

0-14 cm, grayish-brown sandy loam; 14-80 cm, yellowish-brown sandy loam; 80-82 cm+, yellowish-brown sandy clay

0-7 cm, grayish-brown sandy loam; 7-100 cm+, yellowish-brown sandy loam

0-7 cm, grayish-brown sandy loam; 7-100 cm+, yellowish-brown sandy loam

0-86 cm, yellowish-brown sandy loam; 86-89 cm+, yellowish-brown sandy clay

0-100 cm+, yellowish-brown sandy loam (prehistoric artifacts in the sandy loam zone, 4lLN342)

0-100 cm+, yellowish-brown sandy loam

0-85 cm, yellowish-brown sandy loam; 85-87 cm+, yellowish-red clay 
ST 119

ST 120

ST 121

ST 122

ST 123

ST 124

ST 125

ST 126

ST 127

ST 128

ST 129

ST 130

ST 131

ST 132

ST 133

ST 134

ST 135

ST 136

ST 137

ST 138

ST 139

ST 140

ST 141

ST 142

ST 143

ST 144

ST 145

ST 146

ST 147

ST 148

ST 149

0-61 cm, yellowish-brown sandy loam; 6l-63 $\mathrm{cm}+$, yellowish-red clay

0-49 cm, yellowish-brown sandy loam; $49 \mathrm{~cm}+$, yellowish-red clay

0-10 cm, grayish-brown fine sandy loam; $10-101 \mathrm{~cm}+$, yellowish-brown fine sandy loam (prehistoric artifacts in the sandy loam zones, 4lLN347)

0-15 cm, brown fine sandy loam; 15-70 cm, yellowish-brown fine sandy loam; 70-74 cm+, yellowish-brown sandy clay

0-13 cm, brown fine sandy loam; 13-100 cm+, yellowish-brown fine sandy loam (prehistoric artifacts in lower fine sandy loam zone, 4lLN347)

0-95 cm, yellowish-brown fine sandy loam; 95-97 cm+, yellowish-brown sandy clay

0-108 cm+, yellowish-brown fine sandy loam (prehistoric artifacts in fine sandy loam, 4lLN347)

0-98 cm, yellowish-brown fine sandy loam; $98-100 \mathrm{~cm}+$, yellowish-brown sandy clay

0-18 cm, brown fine sandy loam; 18-102 cm+, yellowish-brown fine sandy loam

0-12 cm, brown fine sandy loam; $12-100 \mathrm{~cm}+$, yellowish-brown fine sandy loam

0-14 cm, brown fine sandy loam; 14-101 cm+, yellowish-brown fine sandy loam

0-17 cm, brown fine sandy loam; 17-100 cm+, yellowish-brown sandy loam

0-100 cm+, yellowish-brown sandy loam

0-29 cm, yellowish-brown fine sandy loam; $29-31 \mathrm{~cm}+$, yellowish-red clay

0-5 cm, dark grayish-brown sandy loam; 5-10 cm+, yellowish-red clay

0-20 cm, brown sandy loam; 20-23 cm+, yellowish-red clay

0-17 cm, yellowish-brown sandy loam; 17-20 cm+, yellowish-red clay

0-5 cm, very dark grayish-brown sandy loam midden; 5-10 cm+, yellowish-red clay (sandy loam zone contains historical artifacts, 4lLN307)

0-18 cm, dark yellowish-brown sandy loam; 18-20 cm+, yellowish-red clay (sandy loam zone contains historical artifacts, 4lLN307)

0-18 cm, dark yellowish-brown sandy loam; $18 \mathrm{~cm}+$, yellowish-red clay (sandy loam sediments contain historical artifacts, 4 lLN307)

0-8 cm, dark grayish-brown sandy loam; 8-54 cm, dark yellowish-brown sandy loam; $54-56 \mathrm{~cm}+$, yellowish-red sandy clay

0-25 cm, dark yellowish-brown sandy loam; 25-27 cm+, yellowish-red sandy clay

0-14 cm, dark yellowish-brown sandy loam; 14-16 cm+, yellowish-red sandy clay

0-16 cm, dark yellowish-brown sandy loam; 16-17 cm+, yellowish-red clay

0-49 cm, yellowish-brown sandy loam; $49-51 \mathrm{~cm}+$, brownish-yellow clay (sandy loam zone contains historical artifacts, $41 \mathrm{LN} 306$ )

0-30 cm, yellowish-brown sandy loam; 30-33 cm+, brownish-yellow clay (sandy loam zone contains historical artifacts, $41 \mathrm{LN} 306$ )

0-60 cm, yellowish-brown sandy loam; 60-62 cm+, brownish-yellow clay

0-38 cm, yellowish-brown sandy loam; $38-43 \mathrm{~cm}+$, brownish-yellow clay (sandy loam zone contains historical artifacts, $41 \mathrm{LN} 306$ )

0-18 cm, dark grayish-brown sandy loam midden; 18-22 cm+, brownish-yellow clay (sandy loam midden zone contains historical artifacts, 4lLN306)

0-15 cm, yellowish-brown sandy loam; 15-18 cm+, brownish-yellow sandy clay (sandy loam zone contains historical artifacts, $41 \mathrm{LN} 306$ )

0-20 cm, yellowish-brown sandy loam; $20-21 \mathrm{~cm}+$, yellowish-red clay 
ST 150

ST 151

ST 152

ST 153

ST 154

ST 155

ST 156

ST 157

ST 158

ST 159

ST 160

ST 161

ST 162

ST 163

ST 164

ST 165

ST 166

ST 167

ST 168

ST 169

ST 170

ST 171

ST 172

ST 173

ST 174

ST 175

ST 176

0-30 cm, yellowish-brown sandy loam; 30-32 cm+, brownish-yellow sandy clay (sandy loam zone contains historical artifacts, $41 \mathrm{LN} 306$ )

0-11 cm, brown sandy loam; 1 1-34 cm, yellowish-brown sandy loam; $34-36 \mathrm{~cm}+$, brownish-yellow sandy clay (sandy loam zones contain historical artifacts, 4lLN306)

0-5 cm, very dark grayish-brown sandy loam; 5-10 cm+, red clay

0-5 cm, very dark grayish-brown sandy loam; 5-10 cm+, red clay

0-55 cm, yellowish-brown sandy loam; 55-58 cm+, yellowish-brown sandy clay (sandy loam zone contains historical artifacts, 41LN313)

0-8 cm, very dark grayish-brown sandy loam; 8-47 cm, yellowish-brown sandy loam; 47-49 cm+, yellowish-brown sandy clay (sandy loam zones contain historical artifacts, 4lLN313)

0-28 cm, yellowish-brown sandy loam; $28-32 \mathrm{~cm}+$, yellowish-brown sandy clay 0-20 cm, brown sandy loam; 20-39 cm, yellowish-brown sandy loam; 39-42 cm+, yellowish-brown sandy clay

0-5 cm, dark grayish-brown sandy loam; 5-39 cm, yellowish-brown sandy loam; 39-41 $\mathrm{cm}+$, yellowish-brown sandy clay

0-45 cm, yellowish-brown sandy loam; $45-47 \mathrm{~cm}+$, yellowish-brown sandy clay

0-45 cm, yellowish-brown sandy loam; 45-48 cm+, yellowish-brown sandy clay (sandy loam zone contains historical artifacts, 41LN313)

0-34 cm, yellowish-brown sandy loam; $34-36 \mathrm{~cm}+$, yellowish-brown sandy clay

0-12 cm, brown sandy loam; 12-30 cm, yellowish-brown sandy loam; 30-32 cm+, yellowish-brown sandy clay

0-48 cm, yellowish-brown sandy loam; 48-49 cm+, yellowish-brown sandy clay (sandy loam zone contains historical artifacts, $41 \mathrm{LN} 313$ )

0-7 cm, brown sandy loam; 7-56 cm, yellowish-brown sandy loam; 56-57 cm+, yellowishred clay (sandy loam zones contain historical artifacts, 41LN313)

0-35 cm, yellowish-brown sandy loam; 35-36 cm+, yellowish-red clay

0-7 cm, brown sandy loam; 7-68 cm, yellowish-brown sandy loam; 68-69 cm+, yellowishred sandy clay

0-8 cm, very dark grayish-brown sandy loam; 8-36 cm, yellowish-brown sandy loam; 36 $\mathrm{cm}+$, yellowish-brown sandy clay

0-45 cm, yellowish-brown sandy loam; 45-47 cm+, red clay

0-17 cm, yellowish-brown sandy loam; 17-20 cm+, red clay (sandy loam zone contains historical artifacts, 4lLN312)

0-15 cm, yellowish-brown sandy loam; 15-20 cm+, red clay (sandy loam zone contains historical artifacts: piece of a 55 gallon drum, not collected, 4lLN312)

0-23 cm, yellowish-brown sandy loam; $23-25 \mathrm{~cm}+$, red clay (sandy loam zone contains historical artifacts, 4lLN312)

0-27 cm, yellowish-brown sandy loam; $27-30 \mathrm{~cm}+$, red clay

0-23 cm, yellowish-brown sandy loam; $23-25 \mathrm{~cm}+$, yellowish-brown sandy clay

0-20 cm, yellowish-brown sandy loam; $20-21 \mathrm{~cm}+$, yellowish-red clay

0-8 cm, yellowish-brown sandy loam; 8-12 cm+, yellowish-red sandy clay (sandy loam zone contains historical artifacts, $41 \mathrm{LN} 312$ )

0-12 cm, yellowish-brown sandy loam; 12-13 cm+, red clay (sandy loam zone contains historical artifacts, 4lLN312) 
ST 186

ST 187

ST 188

ST 189

ST 190

ST 191

ST 192

ST 193

ST 194

ST 195

ST 196

ST 197

ST 198

ST 199

ST 200

ST 201

ST 202

ST 203

ST 204

ST 205

ST 206

ST 207

ST 208

ST 209

ST 210

ST 211

ST 212

0-11 cm, yellowish-brown sandy loam; $11-12 \mathrm{~cm}+$, red clay

0-11 cm, yellowish-brown sandy loam; 11-12 cm+, red clay (sandy loam zone contains historical artifacts, 41LN312)

0-12 cm, yellowish-brown sandy loam; $12-13 \mathrm{~cm}+$, red clay

0-3 cm, red sand; 3-25 cm, brown sandy loam; 25-27 cm+, red clay

0-80 cm, brown sand; $80-83 \mathrm{~cm}+$, red clay (sand zone contains prehistoric artifacts, 41LN310)

0-21 cm, brown sand; $21-24 \mathrm{~cm}+$, red clay

0-100 cm+, yellowish-brown sand

0-26 cm, brown sand; 26-104 cm+, yellowish-brown sand (lower sand zone contains prehistoric artifacts, $41 \mathrm{LN} 310$ )

0-27 cm, brown sand; 27-92 cm, yellowish-brown sand; 92-95 cm+, yellowish-brown sandy clay (both sand zones contain prehistoric artifacts, 4lLN310)

0-25 cm, yellowish-brown sand; $25-27 \mathrm{~cm}+$, yellowish-brown sandy clay

0-24 cm, yellowish-brown sand; $24-25 \mathrm{~cm}+$, red clay

0-15 cm, yellowish-brown sand; 15-18 cm+, red clay

0-100 cm+, yellowish-brown sand (upper part of sand zone contains prehistoric artifacts, $41 \mathrm{LN} 310$ )

0-22 cm, yellowish-brown sand; 22-25 cm+, red clay

0-16 cm, brown sand; $16-17 \mathrm{~cm}+$, red clay

0-15 cm, brown sand; $15-16 \mathrm{~cm}+$, red clay

0-17 cm, brown sand; $17-18 \mathrm{~cm}+$, red clay

0-20 cm, brown sand; $20-21 \mathrm{~cm}+$, red clay

$0-8 \mathrm{~cm}+$, red clay

0-14 cm, brown sand; $14-80 \mathrm{~cm}$, yellowish-brown sand; $80-82 \mathrm{~cm}+$, red clay

0-6 cm, brown sand; 6-18 cm, yellowish-brown sand; 18-19 cm+, red clay

0-12 cm, brown sand; 12-106 cm+, yellowish-brown sand

0-9 cm, brown sand; 9-45 cm, yellowish-brown sand; $45-46 \mathrm{~cm}+$, red clay

0-37 cm, brown sand; $37 \mathrm{~cm}+$, yellowish-red clay

0-25 cm, yellowish-brown sandy loam; $25 \mathrm{~cm}+$, red clay

0-21 cm, brown sand; $21 \mathrm{~cm}+$, yellowish-red clay

0-5 cm, dark grayish-brown sandy loam; 5-103 cm+, dark yellowish-brown sandy loam

0-100 cm+, dark yellowish-brown sandy loam

0-102 cm+, dark yellowish-brown sandy loam

0-5 cm, dark grayish-brown sandy loam; 5-100 cm+, dark yellowish-brown sandy loam

0-100 cm+, dark yellowish-brown sandy loam

0-9 cm, brown sandy loam; 9-102 cm+, dark yellowish-brown sandy loam

0-12 cm, brown sandy loam; $12-103 \mathrm{~cm}+$, dark yellowish-brown sandy loam

0-7 cm, dark grayish-brown sandy loam; 7-54 cm, dark yellowish-brown sandy loam;

54-58 cm+, yellowish-brown sandy clay

0-100 cm+, dark yellowish-brown sandy loam

0-5 cm, dark grayish-brown sandy loam; 5-101 cm+, dark yellowish-brown sandy loam (lower sandy loam zone has prehistoric artifacts, 4lLN339) 

yellowish-brown sandy loam; 83-85 $\mathrm{cm}+$, yellowish-red clay $\mathrm{cm}+$, yellowish-brown sandy clay $\mathrm{cm}+$, yellowish-brown sandy clay

ST 216

ST 217

ST 218

ST 219

ST 220

ST 221

ST 222

ST 223

ST 224

ST 225

ST 226

ST 227

ST 228

ST 229

ST 230

ST 231

ST 232

ST 233

ST 234

ST 235

ST 236

ST 237

ST 238

ST 239

ST 240

ST 241

ST 242 0-36 cm, yellowish-brown sandy loam; $36-40 \mathrm{~cm}+$, yellowish-brown sandy clay 0-49 cm, yellowish-brown sandy loam; 49-52 cm+, yellowish-brown sandy clay 0-14 cm, yellowish-brown sandy loam; 14-15 cm+, yellowish-red clay 0-11 cm, brown sandy loam; 1 1-56 cm, yellowish-brown sandy loam; 56-57 cm+, yellowish-red clay

0-41 cm, brown sandy loam; 41-42 cm+, yellowish-brown sandy clay 0-30 cm, brown sandy loam; 30-32 cm+, yellowish-brown sandy clay 0-9 cm, dark grayish-brown sandy loam; 9-59 cm, brown sandy loam; 59-100 cm+, dark yellowish-brown sandy loam

0-33 cm, brown sandy loam; 33-66 cm, dark yellowish-brown sandy loam; $66 \mathrm{~cm}+$, yellowish-red clay

0-10 cm, dark grayish-brown sandy loam; 10-24 cm, dark yellowish-brown sandy loam; 24-26 cm+, yellowish-red clay

0-10 cm, dark grayish-brown sandy loam; 10-27 cm, yellowish-brown sandy loam; 27-30 $\mathrm{cm}+$, yellowish-red clay 0-5 cm, dark grayish-brown sandy loam; 5-24 cm, yellowish-brown sandy loam; 24-26 $\mathrm{cm}+$, yellowish-red clay 0-24 cm, yellowish-brown sandy loam; $24-26 \mathrm{~cm}+$, yellowish-red clay 0-22 cm, yellowish-brown sandy loam; $22-25 \mathrm{~cm}+$, yellowish-red clay 0-15 cm, yellowish-brown sandy loam; $15-20 \mathrm{~cm}+$, yellowish-red clay 0-80 cm, yellowish-brown sandy loam; $80-82 \mathrm{~cm}+$, yellowish-brown sandy clay 0-53 cm, yellowish-brown sandy loam; 53-54 cm+, yellowish-brown sandy clay $0-5 \mathrm{~cm}+$, red clay 0-8 cm, brown sandy loam; 8-10 cm+, red clay 0-21 cm, brown sandy loam; 21-22 cm+, red clay 0-20 cm, yellowish-brown sandy loam; $20 \mathrm{~cm}+$, yellowish-red clay 0-32 cm, yellowish-brown sandy loam; $32 \mathrm{~cm}+$, yellowish-red clay 0-10 cm, dark grayish-brown sandy loam; 10-50 cm, yellowish-brown sandy loam; 50-52 $\mathrm{cm}+$, brownish-yellow sandy clay 0-10 cm, dark grayish-brown sandy loam; $10-45 \mathrm{~cm}$, yellowish-brown sandy loam; 45-47 $\mathrm{cm}+$, yellowish-brown sandy clay 0-15 cm, dark grayish-brown sandy loam; 15-67 cm, yellowish-brown sandy loam; 67-69 $\mathrm{cm}+$, yellowish-brown sandy clay 0-100 cm+, yellowish-brown sandy loam (upper part of sandy loam zone contains historical artifacts, 4lLN318)

0-92 cm, yellowish-brown sandy loam; 92-94 cm+, yellowish-red clay (historic artifacts in the upper part of the sandy loam zone, 4lLN318)

0-20 $\mathrm{cm}+$, disturbed sediments 
0-22 cm, yellowish-brown sandy loam; $22-25 \mathrm{~cm}+$, yellowish-red clay (sandy loam zone contains historical artifacts, 4lLN318)

ST 244

ST 245

ST 246

ST 247

ST 248

ST 249

ST 250

ST 251

ST 252

ST 253

ST 254

ST 255

ST 256

ST 257

ST 258

ST 259

ST 260

ST 261

ST 262

ST 263

ST 264

ST 265

ST 266

ST 267

ST 268

ST 269

ST 270

ST 271

ST 272

0-100 cm+, yellowish-brown sandy loam

0-22 cm, dark grayish-brown sandy loam; 22-105 cm+, yellowish-brown sandy loam (yellowish-brown sandy loam zone contains historical artifacts, 4lLN318)

0-23 cm, brown sandy loam; 23-102 cm+, yellowish-brown sandy loam

0-17 cm, brown sandy loam; 17-106 cm+, yellowish-brown sandy loam

0-31 cm, brown sandy loam; 31-100 cm+, yellowish-brown sandy loam

0-32 cm, brown sandy loam; 32-110 cm+, yellowish-brown sandy loam

0-15 cm, dark grayish-brown sandy loam; $15-50 \mathrm{~cm}$, yellowish-brown sandy loam; 50-52 $\mathrm{cm}+$, yellowish-brown sandy clay

0-78 cm, yellowish-brown sandy loam; 78-80 $\mathrm{cm}+$, yellowish-brown sandy clay

0-87 cm, yellowish-brown sandy loam; 87-90 cm+, yellowish-brown sandy clay

0-14 cm, dark grayish-brown sandy loam; 14-103 cm+, yellowish-brown sandy loam

0-12 cm, dark grayish-brown sandy loam; 12-71 cm, yellowish-brown sandy loam; 11-72 $\mathrm{cm}+$, yellowish-brown sandy clay

0-14 cm, dark grayish-brown sandy loam; 14-101 cm+, yellowish-brown sandy loam

0-20 cm, dark grayish-brown sandy loam; $20-100 \mathrm{~cm}+$, pale brown fine sandy loam

0-86 cm, pale brown fine sandy loam; 86-89 cm+, yellowish-brown sandy clay (fine sandy loam zone contains historical artifacts, 4lLN314)

0-75 cm, pale brown fine sandy loam; 75-79 cm+, yellowish-brown sandy clay (fine sandy loam zone contains historical artifacts, 4lLN314)

0-30 cm, brown fine sandy loam; $30-80 \mathrm{~cm}$, pale brown fine sandy loam; $80-82 \mathrm{~cm}+$, yellowish-brown sandy clay

0-30 cm, brown fine sandy loam; 30-72 cm+, pale brown fine sandy loam; 72-74 cm+, yellowish-brown sandy clay

0-29 cm, brown fine sandy loam; 29-100 cm+, pale brown fine sandy loam

0-31 cm, brown fine sandy loam; 31-67 cm, pale brown fine sandy loam; $67-69 \mathrm{~cm}+$, yellowish-brown sandy clay

0-70 cm, brown fine sandy loam; 70-100 cm+, pale brown fine sandy loam (upper fine sandy loam zone contains historical artifacts, 41LN314)

0-100 cm+, pale brown fine sandy loam

0-100 $\mathrm{cm}+$, pale brown fine sandy loam

0-100 cm+, pale brown fine sandy loam

0-100 $\mathrm{cm}+$, pale brown fine sandy loam

0-8 cm, brown sandy loam; 8-67 cm, pale brown fine sandy loam; $67 \mathrm{~cm}+$, yellowishbrown sandy clay

0-12 cm, brown sandy loam; 12-102 cm+, pale brown fine sandy loam (fine sandy loam zones contain historical artifacts, 4 lLN314)

0-9 cm, brown sandy loam; 9-102 cm+, pale brown fine sandy loam

0-14 cm, brown sandy loam; 14-108 cm+, pale brown fine sandy loam (both sediment zones contain historical artifacts, $41 \mathrm{LN} 314$ )

0-9 cm, brown sandy loam; 9-101 cm+, pale brown fine sandy loam 
0-43 cm, brown fine sandy loam; 43-93 cm, pale brown fine sandy loam; $93 \mathrm{~cm}+$, yellowish-brown sandy clay (upper fine sandy loam zone contains historical artifacts, 41LN314)

ST 274

ST 275

ST 276

ST 277

ST 278

ST 279

ST 280

ST 281

ST 282

ST 283

ST 284

ST 285

ST 286

ST 287

ST 288

ST 289

ST 290

ST 291

ST 292

ST 293

ST 294

ST 295

ST 296

ST 297

ST 298

0-100 cm+, pale brown fine sandy loam (fine sandy loam zone contains historical artifacts, 41LN314)

0-15 cm, brown sandy loam; 15-72 cm, yellowish-brown sandy loam; $72-74 \mathrm{~cm}+$, brownish-yellow sandy clay

0-19 cm, brown sandy loam; 19-66 cm, yellowish-brown sandy loam; 66-69 cm+, brownish-yellow sandy clay

0-19 cm, brown sandy loam; 19-77 cm, yellowish-brown sandy loam; 77-80 cm+, brownish-yellow sandy clay

0-20 cm, brow sandy loam; 20-73 cm, yellowish-brown sandy loam; 73-76 cm+, brownishyellow sandy clay

0-54 cm, yellowish-brown sandy loam; 54-60 cm+, brownish-yellow sandy clay (sandy loam zone contains historical artifacts, 4lLN372)

0-78 cm, yellowish-brown sandy loam; 78-80 cm+, brownish-yellow sandy clay

0-100 cm+, yellowish-brown sandy loam

0-40 cm, brown sandy loam with red sandy loam mottles; 40-86 cm, yellowish-brown sandy loam; 86-103 cm+, pale brown fine sandy loam (sandy loam zones contain historical artifacts, 4lLN372)

0-10 cm, brown sandy loam; 10-44 cm, yellowish-brown sandy loam; $44 \mathrm{~cm}+$, reddishyellow clay (lower sandy loam zone contains historical artifacts, 4lLN372)

0-100 cm+, yellowish-brown fine sandy loam (upper part of the fine sandy loam zone contains historical artifacts, 4lLN353)

0-12 cm, dark grayish-brown sandy loam; 12-100 cm+, yellowish-brown sandy loam

0-16 cm, dark grayish-brown sandy loam; 16-100 cm+, yellowish-brown fine sandy loam

0-100 cm+, yellowish-brown fine sandy loam

0-38 cm, yellowish-brown fine sandy loam; 38-40 cm+, yellowish-brown sandy clay

0-41 cm, yellowish-brown fine sandy loam; 41-43 cm+, yellowish-brown sandy clay

0-8 cm, brown sandy loam; 8-103 cm+, yellowish-brown fine sandy loam (sandy loam and fine sandy loam zones contain historical artifacts, 4lLN353)

0-12 cm, brown sandy loam; 12-105 cm+, yellowish-brown fine sandy loam (sandy loam and fine sandy loam zones contain historical artifacts, 4 lLN353)

0-9 cm, brown sandy loam; 9-62 cm+, yellowish-brown fine sandy loam

0-6 cm, brown sandy loam; 6-111 cm+, yellowish-brown fine sandy loam

0-5 cm, dark grayish-brown sandy loam; 5-59 cm, yellowish-brown sandy loam; 59-61

$\mathrm{cm}+$, yellowish-brown sandy clay

0-5 cm, dark grayish-brown sandy loam; 5-55 cm, yellowish-brown sandy loam; 55-58

$\mathrm{cm}+$, yellowish-brown sandy clay

0-5 cm, dark grayish-brown sandy loam; 5-48 cm, yellowish-brown sandy loam; 48-50

$\mathrm{cm}+$, yellowish-brown sandy clay

0-5 cm, dark grayish-brown sandy loam; 5-100 cm+, yellowish-brown sandy loam

0-5 cm, dark grayish-brown sandy loam; 5-45 cm, yellowish-brown sandy loam; 45-48

$\mathrm{cm}+$, yellowish-brown sandy clay 

$\mathrm{cm}+$, yellowish-red clay

ST 300

ST 301

ST 302

ST 303

ST 304

ST 305

ST 306

ST 307

ST 308

ST 309

ST 310

ST 311

ST 312

ST 313

ST 314

ST 315

ST 316

ST 317

ST 318

ST 319

ST 320

ST 321

ST 322

ST 323

ST 324

ST 325

ST 326

ST 327

ST 328

ST 329

ST 330

ST 331

0-5 cm, dark grayish-brown sandy loam; 5-25 cm, yellowish-brown sandy loam; 25-27 $\mathrm{cm}+$, yellowish-red clay

0-100 cm+, yellowish-brown sandy loam

0-28 cm, yellowish-brown sandy loam; $28-30 \mathrm{~cm}+$, yellowish-brown sandy clay (sandy loam zone contains prehistoric artifacts, $41 \mathrm{LN} 316$ )

0-68 cm, yellowish-brown sandy loam; 68-72 cm+, yellowish-brown sandy clay

0-59 cm, yellowish-brown sandy loam; 59-61 cm+, yellowish-brown sandy clay

0-49 cm, yellowish-brown sandy loam; 49-51 cm+, yellowish-brown sandy clay

0-92 cm, yellowish-brown sandy loam; 92-93 cm+, yellowish-brown sandy clay

0-7 cm, brown sandy loam; 7-51 cm, yellowish-brown sandy loam; 51-52 cm+, yellowishbrown sandy clay

0-61 cm, yellowish-brown sandy loam; 61-62 cm+, yellowish-brown sandy clay

0-47 cm, yellowish-brown sandy loam; 47-48 cm+, yellowish-brown sandy clay (sandy loam zone contains prehistoric artifacts, 4lLN316)

0-55 cm, yellowish-brown sandy loam; 55-57 cm+, yellowish-brown sandy clay

0-34 cm, yellowish-brown sandy loam; 34-36 cm+, yellowish-brown sandy clay

0-35 cm, yellowish-brown sandy clay; $35-37 \mathrm{~cm}+$, yellowish-brown sandy clay

0-29 cm, yellowish-brown sandy loam; 29-32 cm+, yellowish-brown sandy clay

0-48 cm, yellowish-brown sandy loam; 48-50 cm+, yellowish-brown sandy clay (sandy loam zone contains prehistoric artifacts, 4lLN317)

0-78 cm, yellowish-brown sandy loam; $78-80 \mathrm{~cm}+$, yellowish-brown sandy clay

0-48 cm, yellowish-brown sandy loam; 48-50 cm+, yellowish-brown sandy clay (sandy loam zone contains prehistoric artifacts, 4lLN317)

0-35 cm, yellowish-brown sandy loam; 35-37 cm+, yellowish-brown sandy clay

0-14 cm, brown sandy loam; 14-15 cm+, yellowish-red clay

0-37 cm, yellowish-brown sandy loam; $37-38 \mathrm{~cm}+$, yellowish-red clay

0-30 cm, yellowish-brown sandy loam; $30-31 \mathrm{~cm}+$, yellowish-red clay

0-37 cm, yellowish-brown sandy loam; 37-38 cm+, yellowish-brown sandy clay

0-6 cm, brown sandy loam; 6-45 cm, yellowish-brown sandy loam; 45-46 cm+, yellowishbrown sandy clay

0-27 cm, yellowish-brown sandy loam; $27-28 \mathrm{~cm}+$, yellowish-brown sandy clay

0-34 cm, yellowish-brown sandy loam; 34-35 cm+, yellowish-red clay

0-6 cm, brown sandy loam; 6-48 cm, yellowish-brown sandy loam; $48-49 \mathrm{~cm}+$, yellowishred clay

0-42 cm, yellowish-brown sandy loam; $42 \mathrm{~cm}+$, yellowish-brown sandy clay

0-7 cm, dark grayish-brown sandy loam; 7-23 cm, yellowish-brown sandy loam; $23 \mathrm{~cm}+$, yellowish-brown sandy clay

0-5 cm, dark grayish-brown sandy loam; 5-24 cm, yellowish-brown sandy loam; 24-26

$\mathrm{cm}+$, yellowish-red clay (sandy loam zones contain prehistoric artifacts, 41LN327)

0-48 cm, yellowish-brown sandy loam; 48-50 cm+, yellowish-red clay

0-25 cm, yellowish-brown sandy loam; 25-27 cm+, yellowish-brown sandy clay

0-30 cm, yellowish-brown sandy loam; 30-33 cm+, yellowish-brown sandy clay 
ST 332

ST 333

ST 334

ST 335

ST 336

ST 337

ST 338

ST 339

ST 340

ST 341

ST 342

ST 343

ST 344

ST 345

ST 346

ST 347

ST 348

ST 349

ST 350

ST 351

ST 352

ST 353

ST 354

ST 355

ST 356

ST 357

ST 358

ST 359

ST 360

ST 361

ST 362

ST 363

ST 364
0-43 cm, yellowish-brown sandy loam; 43-45 cm+, yellowish-red clay

0-25 cm, yellowish-brown sandy loam; 25-29 cm+, yellowish-red clay (sandy loam zone contains prehistoric artifacts, 4lLN327)

0-65 cm, yellowish-brown sandy loam; $65-70 \mathrm{~cm}+$, yellowish-red clay

0-22 cm, yellowish-brown sandy loam; $22-25 \mathrm{~cm}+$, yellowish-red clay

0-18 cm, yellowish-brown sandy loam; 18-20 cm+, yellowish-red clay (sandy loam zone contains prehistoric artifacts, 4lLN327)

0-15 cm, yellowish-brown sandy loam; $15-16 \mathrm{~cm}+$, yellowish-red clay

0-25 cm, yellowish-brown sandy loam; $25-26 \mathrm{~cm}+$, yellowish-red clay

0-12 cm, yellowish-red clay

0-26 cm, yellowish-brown sandy loam; $26-27 \mathrm{~cm}+$, yellowish-red clay

0-21 cm, yellowish-brown sandy loam; $21-22 \mathrm{~cm}+$, yellowish-red clay

0-16 cm, yellowish-brown sandy loam; $16-17 \mathrm{~cm}+$, yellowish-red clay

0-6 cm, brown sandy loam; 6-41 cm, yellowish-brown sandy loam; 41-43 cm+, yellowishred clay

0-43 cm, yellowish-brown sandy loam; $43 \mathrm{~cm}+$, yellowish-brown sandy clay

0-43 cm, yellowish-brown sandy loam; $43 \mathrm{~cm}+$, yellowish-red clay

0-5 cm, dark grayish-brown sandy loam; 5-38 cm, yellowish-brown sandy loam; $38 \mathrm{~cm}+$, yellowish-red clay

0-5 cm, dark grayish-brown sandy loam; 5-56 cm, yellowish-brown sandy loam; $56 \mathrm{~cm}+$, yellowish-red clay

0-7 cm, dark grayish-brown sandy loam; 7-44 cm, yellowish-brown sandy loam; $44 \mathrm{~cm}+$, yellowish-red clay

0-8 cm, dark grayish-brown sandy loam; 8-34 cm, yellowish-brown sandy loam; $34 \mathrm{~cm}+$, yellowish-brown sandy clay

0-39 cm, yellowish-brown sandy loam; $39 \mathrm{~cm}+$, yellowish-brown sandy clay

0-70 cm, dark yellowish-brown sandy loam; 70-72 cm+, yellowish-brown sandy clay

0-73 cm, dark yellowish-brown sandy loam; 73-76 cm+, yellowish-brown sandy clay

0-75 cm, dark yellowish-brown sandy loam; 75-79 cm+, yellowish-brown sandy clay

0-82 cm, dark yellowish-brown sandy loam; 82-85 cm+, yellowish-red clay

0-57 cm, dark yellowish-brown sandy loam; 57-60 cm+, yellowish-red clay

0-12 cm, brown sandy loam; 12-102 cm+, dark yellowish-brown sandy loam (lower sandy loam zone contains prehistoric artifacts, 4lLN320)

0-27 cm, dark yellowish-brown sandy loam; 27-29 cm+, yellowish-red clay

0-10 cm, brown sandy loam; 10-12 cm+, yellowish-red clay

0-11 cm, brown sandy loam; 11-100 cm+, dark yellowish-brown sandy loam (lower sandy loam zone contains prehistoric artifacts, $41 \mathrm{LN} 320$ )

0-67 cm, dark yellowish-brown sandy loam; $67 \mathrm{~cm}+$, yellowish-red clay

0-67 cm, dark yellowish-brown clay; $67 \mathrm{~cm}+$, yellowish-red clay

0-62 cm, dark yellowish-brown clay; $62 \mathrm{~cm}+$, yellowish-red clay

0-79 cm, dark brown loamy fine sand midden; 79-100 cm+, brown loamy fine sand (loamy fine sand zones contain prehistoric artifacts, 4 lLN308)

0-10l cm+, brown loamy fine sand (loamy fine sand zone contains prehistoric artifacts, 4lLN308) 
0-103 cm+, brown loamy fine sand (loamy fine sand zone contains prehistoric artifacts, $41 \mathrm{LN} 308$ )

ST 366

ST 367

ST 368

ST 369

ST 370

ST 371

ST 372

ST 373

ST 374

ST 375

ST 376

ST 377

ST 378

ST 379

ST 380

ST 381

ST 382

ST 383

ST 384

ST 385

ST 386

ST 387

ST 388

ST 389

ST 390

ST 391

ST 392

0-45 cm, brown loamy fine sand; 45-47 cm+, yellowish-red clay

0-60 cm, brown loamy fine sand; 60-62 cm+, yellowish-red clay (loamy fine sand zone contains prehistoric artifacts, $41 \mathrm{LN} 308$ )

0-35 cm, brown loamy fine sand; 35-37 cm+, yellowish-red clay (loamy fine sand zone contains prehistoric artifacts, $41 \mathrm{LN} 308$ )

0-20 cm, brown loamy fine sand; 20-21 cm+, yellowish-red clay

0-40 cm, brown loamy fine sand; $40-43 \mathrm{~cm}+$, yellowish-red clay (loamy fine sand zone contains prehistoric artifacts, $41 \mathrm{LN} 308$ )

0-60 cm, brown loamy fine sand; 60-63 cm+, yellowish-red clay (loamy fine sand zone contains prehistoric artifacts, 4lLN308)

0-60 cm, brown loamy fine sand; 60-62 cm+, yellowish-red clay (loamy fine sand zone contains prehistoric artifacts, 4lLN308)

0-99 cm+, brown loamy fine sand (loamy fine sand zone contains prehistoric artifacts, 4lLN308)

0-54 cm, brown loamy fine sand; 54-57 cm+, yellowish-red clay

0-87 cm, brown loamy fine sand; 87-89 $\mathrm{cm}+$, yellowish-red clay

0-5 cm, dark grayish-brown sandy loam; $5-38 \mathrm{~cm}$, yellowish-brown sandy loam; 38-40 $\mathrm{cm}+$, yellowish-brown sandy clay

0-100 $\mathrm{cm}+$, brown loamy fine sand (loamy fine sand zone contains prehistoric artifacts, 4lLN308)

0-100 $\mathrm{cm}+$, brown loamy fine sand (loamy fine sand zone contains prehistoric artifacts, 4lLN308)

0-100 $\mathrm{cm}+$, brown loamy fine sand

0-78 cm, brown loamy fine sand; 78-80 cm+, yellowish-red clay (loamy fine sand zone contains prehistoric artifacts, 4lLN308)

0-57 cm, brown loamy fine sand; 57-60 cm+, reddish-yellow sandy clay (loamy fine sand zone contains prehistoric artifacts, $41 \mathrm{LN} 308$ )

0-8 cm, brown loamy fine sand; 8-12 cm+, yellowish-red sandy clay

0-69 cm, brown loamy fine sand; 69-73 cm+, yellowish-red sandy clay (loamy fine sand zone contains prehistoric artifacts, $41 \mathrm{LN} 308$ )

0-81 cm, brown loamy fine sand; 81-82 $\mathrm{cm}+$, yellowish-red sandy clay

0-76 cm, brown loamy fine sand; 76-79 $\mathrm{cm}+$, yellowish-red sandy clay

0-25 cm, yellowish-brown sandy loam; $25-28 \mathrm{~cm}+$, yellowish-red sandy clay

0-45 cm, yellowish-brown sandy loam; 45-48 cm+, yellowish-red sandy clay

0-104 cm+, brown loamy fine sand (loamy fine sand zone contains prehistoric artifacts, 4lLN308)

0-101 cm+, brown loamy fine sand (loamy fine sand zone contains prehistoric artifacts, 41LN308)

0-104 cm+, brown loamy fine sand (loamy fine sand zone contains prehistoric artifacts, 41LN308)

0-101 cm+, brown loamy fine sand (loamy fine sand zone contains prehistoric artifacts, 4lLN308)

0-32 cm, brown loamy fine sand; $32-33 \mathrm{~cm}+$, yellowish-red sandy clay 
ST 393

ST 394

ST 395

ST 396

ST 397

ST 398

ST 399

ST 400

ST 401

ST 402

ST 403

ST 404

ST 405

ST 406

ST 407

ST 408

ST 409

ST 410

ST 411

ST 412

ST 413

ST 414

ST 415

ST 416

ST 417

ST 418

ST 419

ST 420

ST 421
0-16 cm, reddish-brown sandy loam; 16-17 cm+, yellowish-red sandy clay

0-20 cm, reddish-brown sandy loam; $20-21 \mathrm{~cm}+$, yellowish-red clay

0-11 cm, reddish-brown sandy loam; 11-12 cm+, yellowish-red clay

0-15 cm, reddish-brown sandy loam; 15-16 cm+, yellowish-red clay

0-41 cm, brown loamy fine sand; 4l-42 cm+, yellowish-red sandy clay (loamy fine sand zone contains prehistoric artifacts, 4 lLN308)

0-61 cm, brown loamy fine sand; 61-62 cm+, yellowish-red sandy clay (loamy fine sand zone contains prehistoric artifacts, 4 lLN308)

0-67 cm, brown loamy fine sand; 67-68 cm+, yellowish-red sandy clay

0-57 cm, brown loamy fine sand; 57-58 cm+, yellowish-red sandy clay

0-6 cm, dark grayish-brown sandy loam; 6-30 cm, reddish-brown sandy loam; 30-32 cm+, reddish-yellow clay

0-102 $\mathrm{cm}+$, brown loamy fine sand

0-85 cm, brown loamy fine sand; 85-100 cm+, brown loamy fine sand with clay mottles (loamy fine sand zones contain prehistoric artifacts, 4lLN308)

0-100 cm+, brown loamy fine sand (loamy fine sand zone contains prehistoric lithic artifacts, 4lLN308)

0-28 cm, brown loamy fine sand; $28 \mathrm{~cm}+$, yellowish-red sandy clay (loamy fine sand zone contains prehistoric artifacts, $41 \mathrm{LN} 308$ )

0-23 cm, brown loamy fine sand; $23 \mathrm{~cm}+$, yellowish-red sandy clay (loamy fine sand zone contains prehistoric artifacts, $41 \mathrm{LN} 308$ )

0-23 cm, brown loamy fine sand; $23 \mathrm{~cm}+$, yellowish-red sandy clay (loamy fine sand zone contains prehistoric artifacts, 4lLN308)

0-27 cm, brown loamy fine sand; $27 \mathrm{~cm}+$, yellowish-red sandy clay

0-30 cm, brown loamy fine sand; $30 \mathrm{~cm}+$, yellowish-red clay (loamy fine sand zone contains prehistoric artifacts, $41 \mathrm{LN} 308$ )

0-30 cm, brown loamy fine sand; $30 \mathrm{~cm}+$, yellowish-red clay (loamy fine sand zone contains prehistoric artifacts, $41 \mathrm{LN} 308$ )

0-52 cm, brown loamy fine sand; $52 \mathrm{~cm}+$, yellowish-red clay (loamy fine sand zone contains prehistoric artifacts, 4lLN308)

0-82 cm, brown loamy fine sand; $82 \mathrm{~cm}+$, yellowish-red clay (loamy fine sand zone contains prehistoric artifacts, $41 \mathrm{LN} 308$ )

0-32 cm, yellowish-brown sandy loam; $32 \mathrm{~cm}+$, yellowish-red clay

0-9 cm, dark grayish-brown sandy loam; 9-34 cm, yellowish-brown sandy loam; $34 \mathrm{~cm}+$, yellowish-red clay

0-23 cm, yellowish-brown sandy loam; $23-25 \mathrm{~cm}+$, yellowish-red clay (sandy loam zone contains prehistoric artifacts, 4 lLN322)

0-17 cm, yellowish-brown sandy loam; $17-19 \mathrm{~cm}+$, yellowish-red clay

0-20 cm, yellowish-brown sandy loam; $20-23 \mathrm{~cm}+$, yellowish-red clay

0-20 cm, yellowish-brown sandy loam; 20-22 cm+, yellowish-red clay (historic artifacts contained in the sandy loam zone, $41 \mathrm{LN} 322$ )

0-29 cm, yellowish-brown sandy loam; $29-31 \mathrm{~cm}+$, yellowish-red clay

0-52 cm, yellowish-brown sandy loam; $52-54 \mathrm{~cm}+$, yellowish-brown clay (sandy loam zone contains historical artifacts, 4lLN322)

0-70 cm, yellowish-brown sandy loam; 70-72 cm+, yellowish-red clay 
ST 422

ST 423

ST 424

ST 425

ST 426

ST 427

ST 428

ST 429

ST 430

ST 431

ST 432

ST 433

ST 434

ST 435

ST 436

ST 437

ST 438

ST 439

ST 440

ST 441

ST 442

ST 443

ST 444

ST 445

ST 446

ST 447

0-28 cm, yellowish-brown sandy loam; $28-36 \mathrm{~cm}+$, yellowish-red clay

0-33 cm, yellowish-brown sandy loam; 33-40 $\mathrm{cm}+$, yellowish-red clay

0-48 cm, yellowish-brown sandy loam; 48-52 cm+, yellowish-red clay (sandy loam zone contains historical artifacts, 4lLN322)

0-10 cm, yellowish-brown sandy loam; 10-12 cm+, yellowish-red clay

0-5 cm, very dark grayish-brown sandy loam; 5-7 cm+, yellowish-red clay

0-9 cm, grayish-brown sandy loam; 9-90 cm, yellowish-brown sandy loam; 90-92 cm+, yellowish-red clay

0-5 cm, grayish-brown sandy loam; 5-16 cm, yellowish-brown sandy loam; 16-17 cm+, yellowish-red clay

0-5 cm, grayish-brown sandy loam; 5-18 cm, yellowish-brown sandy loam; $18-19 \mathrm{~cm}+$, yellowish-red clay

0-10 cm+, yellowish-red clay

0-6 cm, grayish-brown sandy loam; 6-70 cm, yellowish-brown sandy loam; 70-71

$\mathrm{cm}+$, yellowish-red clay (sandy loam zones contain historical and prehistoric artifacts, 41LN322)

0-12 cm, grayish-brown sandy loam; $12-72 \mathrm{~cm}$, yellowish-brown sandy loam; $72 \mathrm{~cm}+$, yellowish-brown clay (sandy loam zones contain prehistoric artifacts, 4lLN322)

0-4 cm, grayish-brown sandy loam; 4-16 cm, yellowish-brown sandy loam; $16 \mathrm{~cm}+$, yellowish-red clay (sandy loam zones contain historical artifacts, 4lLN322)

0-5 cm, grayish-brown sandy loam; 5-32 cm, yellowish-brown sandy loam; $32 \mathrm{~cm}+$, yellowish-red clay

0-22 cm, yellowish-brown sandy loam; $22-25 \mathrm{~cm}+$, yellowish-brown clay (sandy loam zone contains historical artifacts, 4 lLN309)

0-25 cm, yellowish-brown sandy loam; $25-28 \mathrm{~cm}+$, yellowish-brown clay

0-24 cm, yellowish-brown sandy loam; 24-26 cm+, yellowish-brown clay

0-13 cm, very dark grayish-brown sandy loam midden; $13-25 \mathrm{~cm}$, dark grayish-brown sandy loam; 25-26 cm+, yellowish-brown clay (sandy loam zones contain historical artifacts, 4lLN309)

0-30 cm, yellowish-brown sandy loam; 30-35 cm+, yellowish-brown clay (sandy loam zone contains historical artifacts, 4lLN309)

0-18 cm, yellowish-brown sandy loam; 18-22 $\mathrm{cm}+$, yellowish-brown clay

0-38 cm, yellowish-brown sandy loam; 38-45 cm+, yellowish-brown clay

0-39 cm, yellowish-brown sandy loam; $39-41 \mathrm{~cm}+$, yellowish-brown clay (sandy loam zone contains historical artifacts, 4 lLN309)

0-7 cm, grayish-brown sandy loam; 7-4l cm, yellowish-brown sandy loam; 41-42 cm+, yellowish-brown clay (sandy loam zones contain historical artifacts, 4 lLN309)

0-6 cm, grayish-brown sandy loam; 6-36 cm, yellowish-brown sandy loam; $36-37 \mathrm{~cm}+$, yellowish-red clay (sandy loam zones contain historical artifacts, 4lLN309)

0-7 cm, grayish-brown sandy loam; 7-31 cm, yellowish-brown sandy loam; 31-32 cm+, yellowish-brown clay (sandy loam zones contain historical artifacts, 4lLN309)

0-26 cm, yellowish-brown sandy loam; $26-27 \mathrm{~cm}+$, yellowish-brown clay

0-5 cm, grayish-brown sandy loam; 5-23 cm, yellowish-brown sandy loam; 23-24 cm+, yellowish-brown clay 
0-5 cm, grayish-brown sandy loam; 5-38 cm, yellowish-brown sandy loam; $38 \mathrm{~cm}+$, yellowish-red clay

ST 449 0-6 cm, grayish-brown sandy loam; 6-15 cm+, brick layer (sandy loam zone contains historical brick fragments, 41LN309)

ST 451

ST 452

ST 453

ST 454

ST 455

ST 456

ST 457

ST 458

ST 459

ST 460

ST 461

ST 462

ST 463

ST 464

ST 465

ST 466

ST 467

ST 468

ST 469

ST 470

ST 471

ST 472

ST 473

ST 474

ST 475
0-15 cm, yellowish-brown sandy loam; $15-18 \mathrm{~cm}+$, yellowish-red clay

0-38 cm, yellowish-brown sandy loam; 38-42 cm+, yellowish-brown clay

0-10 cm+, yellowish-red clay

0-15 cm, yellowish-brown sandy loam; $15-16 \mathrm{~cm}+$, yellowish-brown clay

0-5 cm, grayish-brown sandy loam; 5-45 cm, red sandy loam; 45-46 cm+, yellowish-red

clay (sandy loam zones contain historical brick fragments, 4lLN311)

0-7 cm, grayish-brown sandy loam; 7-32 cm, yellowish-brown sandy loam; $32 \mathrm{~cm}+$, yellowish-brown clay

0-18 cm, yellowish-brown sandy loam; $18 \mathrm{~cm}+$, yellowish-red clay

0-52 cm, yellowish-brown sandy loam; $52 \mathrm{~cm}+$, yellowish-red clay

0-40 cm, yellowish-brown sandy loam; $40 \mathrm{~cm}+$, yellowish-brown clay

0-14 cm, dark yellowish-brown sandy loam; 14-17 cm+, red clay

0-20 cm, dark yellowish-brown sandy loam; $20-24 \mathrm{~cm}+$, red clay (sandy loam zone contains prehistoric artifacts, 4lLN319)

0-27 cm, dark yellowish-brown sandy loam; 27-30 cm+, yellowish-brown clay (sandy loam zone contains historical artifacts, 41LN319)

0-20 cm, dark yellowish-brown sandy loam; $20-23 \mathrm{~cm}+$, red clay (sandy loam zone contains historical artifacts, 41LN319)

0-17 cm, yellowish-brown sandy loam; 17-19 cm+, yellowish-brown clay (sandy loam zone contains historical artifacts, 4lLN319)

0-12 cm, yellowish-brown sandy loam; 12-14 cm+, red clay

0-18 cm, dark yellowish-brown sandy loam; $18-20 \mathrm{~cm}+$, red clay

0-22 cm, dark yellowish-brown sandy loam; $22-25 \mathrm{~cm}+$, red clay

0-48 cm, dark yellowish-brown sandy loam; 48-52 cm+, yellowish-brown clay (sandy loam zone contains historical artifacts, $41 \mathrm{LN} 319$ )

0-20 cm, dark yellowish-brown sandy loam; $20-23 \mathrm{~cm}+$, yellowish-brown clay (sandy loam zone contains historical artifacts, 4lLN319)

0-6 cm, grayish-brown sandy loam; 6-7 cm+, red clay (sandy loam zone contains historical artifacts, 4lLN319)

0-5 cm, grayish-brown sandy loam; 5-16 cm, dark yellowish-brown sandy loam; 16-17 $\mathrm{cm}+$, yellowish-brown clay

0-11 cm, dark yellowish-brown sandy loam; 11-12 cm+, red clay (sandy loam zone contains historical artifacts, 41LN319)

0-5 cm, grayish-brown sandy loam; 5-40 cm, yellowish-brown sandy loam; 40-41 cm+, yellowish-brown clay

0-5 cm, grayish-brown sandy loam; 5-36 cm, yellowish-brown sandy loam; $36-37 \mathrm{~cm}+$, yellowish-brown clay

0-40 cm, yellowish-brown sandy loam; $40 \mathrm{~cm}+$, yellowish-brown clay 
0-24 cm, dark yellowish-brown sandy loam; $24 \mathrm{~cm}+$, red clay (sandy loam zone contains historical artifacts, 41LN319)

ST $477 \quad 0-26 \mathrm{~cm}$, yellowish-brown sandy loam; $26 \mathrm{~cm}+$, red clay (sandy loam zone contains historical artifacts, 4lLN319)

ST $478 \quad$ 0-20 cm, yellowish-brown sandy loam; 20-23 cm+, yellowish-brown clay (sandy loam zone contains historical artifacts, $41 \mathrm{LN} 355$ )

ST 479

0-20 cm, yellowish-brown sandy loam; 20-22 cm+, yellowish-brown clay (sandy loam zone contains historical artifacts, $41 \mathrm{LN} 355$ )

ST 480

0-15 cm, yellowish-brown sandy loam; $15-17 \mathrm{~cm}+$, red clay

ST 481

0-13 cm, yellowish-brown sandy loam; $13-15 \mathrm{~cm}+$, red clay

ST 482

0-27 cm, yellowish-brown sandy loam; $27-29 \mathrm{~cm}+$, yellowish-brown clay (sandy loam zone contains historical artifacts, 4lLN355)

ST 483

0-10 cm, yellowish-brown sandy loam; $10-13 \mathrm{~cm}+$, red clay

ST 484

0-23 cm, yellowish-brown sandy loam; $23-25 \mathrm{~cm}+$, red clay

ST 485

0-35 cm, yellowish-brown sandy loam; $35-38 \mathrm{~cm}+$, yellowish-brown clay

ST 486

ST 487

ST 488

0-37 cm, yellowish-brown sandy loam; $37-40 \mathrm{~cm}+$, yellowish-brown clay (sandy loam zone contains historical artifacts, $41 \mathrm{LN} 355)$

0-15 cm, yellowish-brown sandy loam; $15-18 \mathrm{~cm}+$, red clay

0-32 cm, yellowish-brown sandy loam; $32 \mathrm{~cm}+$, red clay (sandy loam zone contains historical artifacts, 4lLN355)

ST 489

0-16 cm, yellowish-brown sandy loam; $16-17 \mathrm{~cm}+$, yellowish-brown clay

ST 490

ST 491

0-17 cm, yellowish-brown sandy loam; $17-18 \mathrm{~cm}+$, yellowish-brown clay (sandy loam zone contains historical artifacts, $41 \mathrm{LN} 355)$

0-6 cm, grayish-brown sandy loam; 6-53 cm, yellowish-brown sandy loam; 53-54 cm+, yellowish-red clay

ST $492 \quad 0-5 \mathrm{~cm}$, grayish-brown sandy loam; 5-42 cm, yellowish-brown sandy loam; $42-43 \mathrm{~cm}+$, yellowish-red clay

ST $493 \quad 0-10 \mathrm{~cm}$, yellowish-brown sandy loam; 10-13 cm+, red clay

ST $494 \quad 0-15 \mathrm{~cm}$, dark yellowish-brown sandy loam; $15 \mathrm{~cm}+$, red clay (sandy loam zone contains historical artifacts, 4lLN356)

ST $495 \quad$ 0-10 cm, dark yellowish-brown sandy loam; $10 \mathrm{~cm}+$, yellowish-brown clay (sandy loam zone contains historical artifacts, $41 \mathrm{LN} 356$ )

ST 496

ST 497

0-19 cm, yellowish-brown sandy loam; $19 \mathrm{~cm}+$, yellowish-brown clay

ST 498

0-20 cm, yellowish-brown sandy loam; $20-22 \mathrm{~cm}+$, yellowish-brown clay

0-20 cm, dark yellowish-brown sandy loam; $20-22 \mathrm{~cm}+$, red clay (sandy loam zone contains historical artifacts, 4lLN356)

ST 499

0-19 cm, yellowish-brown sandy loam; $19-20 \mathrm{~cm}+$, yellowish-brown clay

ST 500

ST 501

0-14 cm, yellowish-brown sandy loam; 14-16 cm+, yellowish-brown clay

ST 502

0-15 cm, yellowish-brown sandy loam; $15-20 \mathrm{~cm}+$, yellowish-brown clay

ST 503

0-18 cm, yellowish-brown sandy loam; 18-20 cm+, yellowish-red clay

0-40 cm, yellowish-brown sandy loam; $40-43 \mathrm{~cm}+$, yellowish-brown clay (sandy loam zone contains historical artifacts, 4 lLN356)

ST 504

0-8 cm, dark yellowish-brown sandy loam; 8-9 cm+, yellowish-red clay (sandy loam zone contains historical artifacts, 4lLN356)

ST 505

0-5 cm, grayish-brown sandy loam; 5-6 cm+, yellowish-red clay 


\begin{tabular}{|c|c|}
\hline ST 506 & 0-10 cm+, yellowish-red clay \\
\hline ST 507 & $\begin{array}{l}0-19 \mathrm{~cm} \text {, brown sandy loam; 19-52 cm, yellowish-brown sandy loam; } 52-54 \mathrm{~cm}+\text {, } \\
\text { brownish-yellow clay }\end{array}$ \\
\hline ST 508 & 0-39 cm, yellowish-brown sandy loam; $39-41 \mathrm{~cm}+$, red clay \\
\hline ST 509 & 0-15 cm, brown sandy loam; 15-62 cm+, yellowish-brown sandy loam \\
\hline ST 510 & $\begin{array}{l}0-8 \mathrm{~cm} \text {, very dark grayish-brown sandy loam; } 8-52 \mathrm{~cm} \text {, yellowish-brown sandy loam; } \\
52-54 \mathrm{~cm}+\text {, yellowish-red clay (lower sandy loam zone contains prehistoric artifacts, } \\
\text { 4lLN357) }\end{array}$ \\
\hline ST 511 & $\begin{array}{l}0-9 \mathrm{~cm} \text {, very dark grayish-brown sandy loam; } 9-57 \mathrm{~cm} \text {, yellowish-brown sandy loam; } \\
57-59 \mathrm{~cm}+\text {, yellowish-red clay }\end{array}$ \\
\hline ST 512 & 0-39 cm, yellowish-brown sandy loam; 39-43 cm+, yellowish-brown clay \\
\hline ST 513 & 0-25 cm, yellowish-brown sandy loam; $25-30 \mathrm{~cm}+$, yellowish-brown clay \\
\hline ST 514 & $\begin{array}{l}\text { 0-75 cm, yellowish-brown sandy loam; } 75-83 \mathrm{~cm}+\text {, yellowish-brown clay (sandy loam } \\
\text { zone contains prehistoric and historical artifacts, } 4 \text { lLN357) }\end{array}$ \\
\hline ST 515 & 0-25 cm+, yellowish-brown sandy loam \\
\hline ST 516 & 0-15 cm, yellowish-brown sandy loam; $15-16 \mathrm{~cm}+$, yellowish-brown clay \\
\hline ST 517 & 0-45 cm, yellowish-brown sandy loam; 45-47 cm+, yellowish-brown clay \\
\hline ST 518 & $\begin{array}{l}0-5 \mathrm{~cm} \text {, grayish-brown sandy loam; } 5-51 \mathrm{~cm} \text {, yellowish-brown sandy loam; } 51-52 \mathrm{~cm}+\text {, } \\
\text { yellowish-brown clay }\end{array}$ \\
\hline ST 519 & $\begin{array}{l}0-6 \mathrm{~cm} \text {, grayish-brown sandy loam; 6-73 cm, yellowish-brown sandy loam; } 73-74 \mathrm{~cm}+\text {, } \\
\text { yellowish-red clay }\end{array}$ \\
\hline ST 520 & 0-42 cm, yellowish-brown sandy loam; 42-44 cm+, yellowish-brown clay \\
\hline ST 521 & 0-77 cm, yellowish-brown sandy loam; 77-78 cm+, yellowish-brown clay \\
\hline ST 522 & $\begin{array}{l}0-9 \mathrm{~cm} \text {, grayish-brown sandy loam; } 9-42 \mathrm{~cm} \text {, yellowish-brown sandy loam; } 42 \mathrm{~cm}+\text {, } \\
\text { yellowish-brown clay }\end{array}$ \\
\hline ST 523 & $\begin{array}{l}0-10 \mathrm{~cm} \text {, grayish-brown sandy loam; 10-68 cm, yellowish-brown sandy loam; } 68 \mathrm{~cm}+\text {, } \\
\text { yellowish-brown clay }\end{array}$ \\
\hline ST 524 & $\begin{array}{l}0-11 \mathrm{~cm} \text {, grayish-brown sandy loam; } 11-82 \mathrm{~cm} \text {, yellowish-brown sandy loam; } 82-100 \mathrm{~cm}+\text {, } \\
\text { yellowish-brown sandy loam with lamellae }\end{array}$ \\
\hline ST 525 & $\begin{array}{l}0-10 \mathrm{~cm} \text {, grayish-brown sandy loam; 10-75 cm, yellowish-brown sandy loam; } 75 \mathrm{~cm}+\text {, } \\
\text { yellowish-brown clay }\end{array}$ \\
\hline ST 526 & $\begin{array}{l}\text { 0-9 cm, grayish-brown sandy loam; 9-68 cm, yellowish-brown sandy loam; } 68 \mathrm{~cm}+\text {, } \\
\text { yellowish-brown clay }\end{array}$ \\
\hline ST 527 & $\begin{array}{l}0-100 \mathrm{~cm}+\text {, yellowish-brown sandy loam (sandy loam zone contains prehistoric artifacts, } \\
41 \mathrm{LN} 328 \text { ) }\end{array}$ \\
\hline ST 528 & $0-100 \mathrm{~cm}+$, yellowish-brown sandy loam \\
\hline ST 529 & 0-31 cm, brown sandy loam; 31-100 cm+, yellowish-brown sandy loam \\
\hline ST 530 & 0-60 cm, yellowish-brown sandy loam; 60-63 cm+, yellowish-brown clay \\
\hline ST 531 & 0-60 cm, yellowish-brown sandy loam; 60-62 cm+, yellowish-brown clay \\
\hline ST 532 & 0-63 cm, yellowish-brown sandy loam; 63-67 cm+, yellowish-brown clay \\
\hline ST 533 & $\begin{array}{l}\text { 0-61 cm, yellowish-brown sandy loam; } 61-62 \mathrm{~cm}+\text {, yellowish-brown clay (sandy loam } \\
\text { zone contains prehistoric artifacts, } 41 \mathrm{LN} 328 \text { ) }\end{array}$ \\
\hline ST 534 & 0-57 cm, yellowish-brown sandy loam; 57-58 cm+, yellowish-brown clay \\
\hline ST 535 & 0-102 $\mathrm{cm}+$, yellowish-brown sandy loam \\
\hline
\end{tabular}


ST 536

ST 537

ST 538

ST 539

ST 540

ST 541

ST 542

ST 543

ST 544

ST 545

ST 546

ST 547

ST 548

ST 549

ST 550

ST 551

ST 552

ST 553

ST 554

ST 555

ST 556

ST 557

ST 558

ST 559

ST 560

ST 561

ST 562

ST 563

ST 564

0-64 cm, yellowish-brown sandy loam; $64 \mathrm{~cm}+$, yellowish-brown clay

0-65 cm, yellowish-brown sandy loam; $65 \mathrm{~cm}+$, yellowish-brown clay

0-100 cm+, yellowish-brown sandy loam

0-24 cm, yellowish-brown sandy loam; $24-26 \mathrm{~cm}+$, yellowish-red clay (sandy loam zone contains prehistoric artifacts, $41 \mathrm{LN} 321$ )

0-10 cm, yellowish-brown sandy loam; 10-13 cm+, yellowish-red clay (sandy loam zone contains prehistoric artifacts, 4lLN321)

0-5 cm, very dark grayish-brown sandy loam; 5-10 cm+, yellowish-red clay

0-13 cm, yellowish-brown sandy loam; 13-16 cm+, yellowish-red clay (sandy loam zone contains prehistoric and historical artifacts, $41 \mathrm{LN} 321$ )

0-30 cm, yellowish-brown sandy loam; $30-31 \mathrm{~cm}+$, yellowish-brown clay (sandy loam zone contains prehistoric artifacts, $41 \mathrm{LN} 321$ )

0-44 cm, yellowish-brown sandy loam; 44-46 cm+, yellowish-brown clay (sandy loam zone contains prehistoric artifacts, $41 \mathrm{LN} 321$ )

0-79 cm, yellowish-brown sandy loam; 79-81 cm+, yellowish-red clay (sandy loam zone contains prehistoric artifacts, 41LN321)

0-102 cm+, yellowish-brown sandy loam (lowest part of sandy loam zone contains prehistoric artifacts, 4lLN321)

0-27 cm, yellowish-brown sandy loam; $27-29 \mathrm{~cm}+$, yellowish-red clay

0-43 cm, yellowish-brown sandy loam; 43-46 cm+, yellowish-red clay

0-69 cm, yellowish-brown sandy loam; $69-71 \mathrm{~cm}+$, yellowish-brown clay (sandy loam zone contains prehistoric artifacts, 4 lLN321)

0-100 cm+, yellowish-brown sandy loam (the sandy loam zone contains prehistoric artifacts, $41 \mathrm{LN} 321$ )

0-45 cm, yellowish-brown sandy loam; $45 \mathrm{~cm}+$, yellowish-brown clay

0-18 cm, yellowish-brown sandy loam; $18-20 \mathrm{~cm}+$, yellowish-brown clay

0-15 cm, yellowish-brown sandy loam; 15-20 cm+, yellowish-brown clay (sandy loam zone contains prehistoric artifacts, $41 \mathrm{LN} 321$ )

0-100 cm+, yellowish-brown sandy loam (sandy loam zone contains prehistoric artifacts, 4lLN321)

0-100 cm+, yellowish-brown sandy loam

0-100 cm+, yellowish-brown sandy loam (sandy loam zone contains prehistoric artifacts, 4lLN321)

0-43 cm, yellowish-brown sandy loam; $43-45 \mathrm{~cm}+$, yellowish-brown clay

0-100 cm+, yellowish-brown sandy loam (sandy loam zone contains prehistoric artifacts, 41LN321)

0-100 cm+, yellowish-brown sandy loam

0-101 cm+, yellowish-brown sandy loam (sandy loam zone contains prehistoric artifacts, $41 \mathrm{LN} 321$ )

0-6 cm, grayish-brown sandy loam; 6-23 cm, yellowish-brown sandy loam; $23-24 \mathrm{~cm}+$, yellowish-brown clay

0-40 cm, yellowish-brown sandy loam; $40-41 \mathrm{~cm}+$, yellowish-brown clay

0-11 cm, yellowish-brown sandy loam; $11-12 \mathrm{~cm}+$, yellowish-brown clay

0-10 cm, grayish-brown sandy loam; 10-56 cm, yellowish-brown sandy loam; 56-57 cm+, yellowish-brown clay 
ST 565

ST 566

ST 567

ST 568

ST 569

ST 570

ST 571

ST 572

ST 573

ST 574

ST 575

ST 576

ST 577

ST 578

ST 579

ST 580

ST 581

ST 582

ST 583

ST 584

ST 585

ST 586

ST 587

ST 588

ST 589

ST 590

ST 591

0-20 cm, yellowish-brown sandy loam; $20-21 \mathrm{~cm}+$, yellowish-brown clay

0-5 cm, grayish-brown sandy loam; 5-6 cm+, yellowish-red clay

0-36 cm, yellowish-brown sandy loam; 36-37 cm+, yellowish-brown clay

0-11 cm, yellowish-brown sandy loam; $11-12 \mathrm{~cm}+$, yellowish-red clay

0-27 cm, yellowish-brown sandy loam; $27-28 \mathrm{~cm}+$, yellowish-red clay

0-5 cm, grayish-brown sandy loam; 5-40 cm, yellowish-brown sandy loam; $40-41 \mathrm{~cm}+$, yellowish-brown clay

0-15 cm, yellowish-brown sandy loam; 15-17 cm+, yellowish-red clay

0-10 cm, grayish-brown sandy loam; 10-62 cm, yellowish-brown sandy loam; 62-64 cm+, yellowish-brown clay (sandy loam zones contain prehistoric and historical artifacts, $41 \mathrm{LN} 321$ )

0-6 cm, grayish-brown sandy loam; 6-60 cm, yellowish-brown sandy loam; 60-61 cm+, yellowish-red clay (sandy loam zones contain prehistoric artifacts, 4lLN321)

0-8 cm, grayish-brown sandy loam; 8-76 cm, yellowish-brown sandy loam; 76-77 cm+, yellowish-brown clay

0-83 cm, yellowish-brown sandy loam; 83-84 cm+, yellowish-red clay (sandy loam zone contains prehistoric artifacts, $41 \mathrm{LN} 321$ )

0-85 cm, yellowish-brown sandy loam; 85-100 cm+, yellowish-brown sandy loam with clay lamellae (lower sandy loam zone contains prehistoric artifacts, 4 lLN321)

0-5 cm+, yellowish-red clay

$0-10 \mathrm{~cm}+$, yellowish-red clay

$0-5 \mathrm{~cm}+$, yellowish-red clay

0-49 cm, yellowish-brown sandy loam; $49 \mathrm{~cm}+$, yellowish-brown clay (sandy loam zone contains prehistoric artifacts, $41 \mathrm{LN} 321$ )

0-75 cm, yellowish-brown sandy loam; 75-100 cm+, yellowish-brown sandy loam with clay inclusions (sandy loam zones contain prehistoric artifacts, 4lLN321)

0-10 cm, grayish-brown sandy loam; 10-88 cm, yellowish-brown sandy loam; $88 \mathrm{~cm}+$, yellowish-brown clay

0-8 cm, grayish-brown sandy loam; 8-40 cm, yellowish-brown sandy loam; $40 \mathrm{~cm}+$, yellowish-red clay (sandy loam zones contain prehistoric artifacts, 4lLN321)

0-10 cm+, yellowish-red clay

0-68 cm, yellowish-brown sandy loam; $68 \mathrm{~cm}+$, yellowish-red clay (sandy loam zone contains prehistoric artifacts, $41 \mathrm{LN} 321$ )

0-8 cm, grayish-brown sandy loam; 8-55 cm, yellowish-brown sandy loam; $55 \mathrm{~cm}+$, yellowish-brown clay (lower sandy loam zone contains prehistoric artifacts, 4lLN321)

0-7 cm, grayish-brown sandy loam; 7-36 cm, yellowish-brown sandy loam; $36 \mathrm{~cm}+$, yellowish-brown clay (sandy loam zones contain prehistoric artifacts, 4lLN32 l)

0-104 cm+, dark yellowish-brown fine sandy loam (sandy loam zone contains prehistoric artifacts, 4lLN323)

0-80 cm, yellowish-brown fine sandy loam; 80-100 cm+, grayish-brown sandy loam (upper sandy loam zone contains prehistoric artifacts, 4lLN323)

0-75 cm, yellowish-brown fine sandy loam; 75-100 cm+, grayish-brown sandy loam

0-19 cm, yellowish-brown fine sandy loam; $19-90 \mathrm{~cm}$, dark yellowish-brown fine sandy loam; 90-101 cm+, grayish-brown sandy loam (fine sandy loam and sandy loam zones contain prehistoric artifacts, 4lLN323) 
ST 592

ST 593

ST 594

ST 595

ST 596

ST 597

ST 598

ST 599

ST 600

ST 601

ST 602

ST 603

ST 604

ST 605

ST 606

ST 607

ST 608

ST 609

ST 610

ST 611

ST 612

ST 613

ST 614

ST 615

ST 616

ST 617

ST 618

0-100 cm+, yellowish-brown sandy loam

0-100 cm+, yellowish-brown sandy loam (sandy loam zone contains prehistoric artifacts, 4lLN323)

0-100 cm+, yellowish-brown sandy loam

0-100 cm+, yellowish-brown sandy loam (sandy loam zone contains prehistoric artifacts, $41 \mathrm{LN} 323)$

0-8 cm, grayish-brown sandy loam; 8-77 cm, yellowish-brown sandy loam; 77-78 cm+, yellowish-brown clay

0-101 cm+, yellowish-brown sandy loam

0-101 cm+, yellowish-brown sandy loam

0-104 cm+, yellowish-brown sandy loam

0-41 cm, yellowish-brown sandy loam; 4l-42 cm+, yellowish-brown clay

0-103 cm+, yellowish-brown sandy loam (sandy loam zone contains prehistoric artifacts, 41LN323)

0-103 cm+, yellowish-brown sandy loam (sandy loam zone contains prehistoric artifacts, $41 \mathrm{LN} 323)$

0-100 cm+, yellowish-brown sandy loam (sandy loam zone contains prehistoric artifacts, $41 \mathrm{LN} 323)$

0-100 cm+, yellowish-brown sandy loam

0-52 cm, yellowish-brown sandy loam; $52 \mathrm{~cm}+$, yellowish-brown clay

0-100 cm+, yellowish-brown sandy loam (sandy loam zone contains prehistoric artifacts, $41 \mathrm{LN} 323)$

0-60 cm+, very dark grayish-brown loamy clay

0-80 cm, very dark grayish-brown loamy fine sand midden; 80-100 cm+, dark brown

loamy fine sand midden (loamy fine sand zones contain prehistoric artifacts, 4lLN325)

0-100 cm+, dark brown loamy fine sand midden (loamy fine sand zone contains prehistoric artifacts, 4lLN325)

0-78 cm, yellowish-brown fine sandy loam; 78-80 cm+, yellowish-brown clay (fine sandy loam zone contains prehistoric artifacts, 4lLN325)

0-100 cm+, yellowish-brown fine sandy loam (fine sandy loam zone contains prehistoric artifacts, $41 \mathrm{LN} 325$ )

0-100 cm+, yellowish-brown fine sandy loam (fine sandy loam zone contains prehistoric artifacts, $41 \mathrm{LN} 325$ )

0-100 cm+, yellowish-brown fine sandy loam (fine sandy loam zone contains prehistoric artifacts, 4lLN325)

0-100 cm+, yellowish-brown fine sandy loam (fine sandy loam zone contains prehistoric artifacts, 41LN325)

0-100 cm+, yellowish-brown fine sandy loam

0-100 cm+, yellowish-brown fine sandy loam (fine sandy loam zone contains prehistoric artifacts, 41LN325)

0-83 cm+, yellowish-brown fine sandy loam (fine sandy loam zone contains prehistoric artifacts, 4 lLN325)

0-90 cm, yellowish-brown fine sandy loam; 90-93 cm+, yellowish-brown clay (fine sandy loam zone contains prehistoric artifacts, 4lLN325) 
ST 619

ST 620

ST 621

ST 622

ST 623

ST 624

ST 625

ST 626

ST 627

ST 628

ST 629

ST 630

ST 631

ST 632

ST 633

ST 634

ST 635

ST 636

ST 637

ST 638

ST 639

ST 640

ST 641

ST 642

ST 643

ST 644

ST 645

ST 646

0-100 cm+, yellowish-brown fine sandy loam (fine sandy loam zone contains prehistoric artifacts, 4 lLN325)

0-80 cm, yellowish-brown fine sandy loam; 80-83 cm+, yellowish-brown clay (fine sandy loam zone contains prehistoric artifacts, 4lLN325)

0-103 cm+, yellowish-brown fine sandy loam (fine sandy loam zone contains prehistoric artifacts, 4 lLN325)

0-100 cm+, yellowish-brown fine sandy loam

0-61 cm, yellowish-brown fine sandy loam; 61-63 cm+, yellowish-brown clay

0-101 cm+, yellowish-brown fine sandy loam (fine sandy loam zone contains prehistoric artifacts, 4 lLN325)

0-65 cm, yellowish-brown fine sandy loam; $65-66 \mathrm{~cm}+$, yellowish-red clay

0-108 cm+, yellowish-brown fine sandy loam (fine sandy loam zone contains prehistoric artifacts, $41 \mathrm{LN} 325$ )

0-104 cm+, yellowish-brown fine sandy loam (fine sandy loam zone contains prehistoric artifacts, 4 lLN325)

0-59 cm, yellowish-brown fine sandy loam; 59-60 cm+, yellowish-brown clay (fine sandy loam zone contains prehistoric artifacts, 41LN325)

0-70 cm, yellowish-brown fine sandy loam; 70-71 cm+, yellowish-brown clay (fine sandy loam zone contains prehistoric artifacts, 4lLN325)

0-105 cm+, yellowish-brown fine sandy loam (fine sandy loam zone contains prehistoric artifacts, $41 \mathrm{LN} 325$ )

0-102 cm+, yellowish-brown fine sandy loam (fine sandy loam zone contains prehistoric artifacts, $41 \mathrm{LN} 325$ )

0-100 cm+, yellowish-brown fine sandy loam (fine sandy loam zone contains prehistoric artifacts, 4lLN325)

0-101 cm+, yellowish-brown fine sandy loam

0-49 cm, yellowish-brown fine sandy loam; $49-50 \mathrm{~cm}+$, yellowish-brown clay

0-77 cm, very dark grayish-brown fine sandy loam midden; 77-100 cm+, dark brown fine sandy loam midden (fine sandy loam zones contain prehistoric artifacts, 4lLN325)

0-70 cm, very dark grayish-brown fine sandy loam midden; 70-100 cm+, dark brown fine sandy loam midden (fine sandy loam zones contain prehistoric artifacts, 4lLN325)

0-55 cm, yellowish-brown fine sandy loam; $55 \mathrm{~cm}+$, yellowish-brown clay

0-79 cm, yellowish-brown fine sandy loam; $79 \mathrm{~cm}+$, yellowish-brown clay (fine sandy loam zone contains prehistoric artifacts, $41 \mathrm{LN} 325$ )

0-79 cm, yellowish-brown fine sandy loam; $79 \mathrm{~cm}+$, yellowish-brown clay (fine sandy loam zone contains prehistoric artifacts, $41 \mathrm{LN} 325)$

0-69 cm, yellowish-brown fine sandy loam; $69 \mathrm{~cm}+$, yellowish-brown clay

0-100 cm+, yellowish-brown fine sandy loam

0-100 cm+, yellowish-brown fine sandy loam (fine sandy loam zone contains prehistoric artifacts, $41 \mathrm{LN} 325$ )

0-100 cm+, yellowish-brown fine sandy loam (fine sandy loam zone contains prehistoric artifacts, 4 lLN325)

0-69 cm, yellowish-brown fine sandy loam; $69 \mathrm{~cm}+$, yellowish-brown clay

0-45 cm, yellowish-brown fine sandy loam; $45-48 \mathrm{~cm}+$, yellowish-brown clay

0-68 cm, yellowish-brown fine sandy loam; $68-71 \mathrm{~cm}+$, yellowish-brown clay 
ST 647

ST 648

ST 649

ST 650

ST 651

ST 652

ST 653

ST 654

ST 655

ST 656

ST 657

ST 658

ST 659

ST 660

ST 661

ST 662

ST 663

ST 664

ST 665

ST 666

ST 667

ST 668

ST 669

ST 670

ST 671

ST 672

ST 673

ST 674

ST 675

ST 676

ST 677

ST 678

ST 679
0-70 cm, yellowish-brown fine sandy loam; 70-72 cm+, yellowish-brown clay

0-78 cm, yellowish-brown fine sandy loam; $78-80 \mathrm{~cm}+$, yellowish-brown clay

0-60 cm, yellowish-brown fine sandy loam; $60-63 \mathrm{~cm}+$, yellowish-brown clay

0-48 cm, yellowish-brown fine sandy loam; 48-52 cm+, yellowish-brown clay

0-64 cm, yellowish-brown fine sandy loam; 64-67 cm+, yellowish-brown clay

0-5 cm, dark grayish-brown sandy loam; 5-20 cm, yellowish-brown fine sandy loam; 20-25 $\mathrm{cm}+$, yellowish-brown clay

0-71 cm, yellowish-brown fine sandy loam; 71-73 cm+, yellowish-brown clay

0-50 cm, yellowish-brown fine sandy loam; $50-51 \mathrm{~cm}+$, yellowish-brown clay

0-55 cm, yellowish-brown fine sandy loam; $55-56 \mathrm{~cm}+$, yellowish-red clay

0-56 cm, yellowish-brown fine sandy loam; $56-57 \mathrm{~cm}+$, yellowish-red clay

0-103 cm+, yellowish-brown fine sandy loam (fine sandy loam zone contains prehistoric artifacts, $41 \mathrm{LN} 326$ )

0-101 cm+, yellowish-brown fine sandy loam (fine sandy loam zone contains prehistoric artifacts, 4lLN326)

0-101 cm+, yellowish-brown fine sandy loam

0-42 cm, yellowish-brown fine sandy loam; $42 \mathrm{~cm}+$, yellowish-brown clay

0-60 cm, yellowish-brown fine sandy loam; $60 \mathrm{~cm}+$, yellowish-brown clay (fine sandy loam zone contains prehistoric artifacts, $41 \mathrm{LN} 326$ )

0-100 cm+, yellowish-brown fine sandy loam

0-100 cm+, yellowish-brown fine sandy loam

0-100 cm+, yellowish-brown fine sandy loam

0-100 cm+, yellowish-brown fine sandy loam

0-100 cm+, yellowish-brown fine sandy loam

0-72 cm+, yellowish-brown fine sandy loam (fine sandy loam zone contains historical artifacts, 4lLN303)

0-100 cm+, yellowish-brown fine sandy loam (fine sandy loam zone contains historical artifacts, $41 \mathrm{LN} 303$ )

0-102 cm+, yellowish-brown fine sandy loam

0-12 cm, grayish-brown sandy loam; 12-106 cm+, yellowish-brown fine sandy loam (both soil zones contain historical or prehistoric artifacts, 4lLN303)

0-8 cm, grayish-brown sandy loam; 8-100 cm+, yellowish-brown fine sandy loam

0-102 cm+, yellowish-brown fine sandy loam

0-104 cm+, yellowish-brown fine sandy loam

0-45 cm, pale brown fine sandy loam; 45-48 cm+, yellowish-brown clay

0-5 cm, grayish-brown sandy loam; 5-29 cm, pale brown fine sandy loam; $29-31 \mathrm{~cm}+$, yellowish-brown clay

0-5 cm, grayish-brown sandy loam; $5-30 \mathrm{~cm}$, pale brown fine sandy loam; $30-33 \mathrm{~cm}+$, yellowish-brown clay

0-28 cm, pale brown fine sandy loam; $28-34 \mathrm{~cm}+$, yellowish-brown clay (fine sandy loam zone contains historical artifacts, 4 lLN302)

0-100 cm+, pale brown fine sandy loam (upper fine sandy loam zone contains historical artifacts, $41 \mathrm{LN} 302$ )

0-100 $\mathrm{cm}+$, pale brown fine sandy loam 
ST 680

ST 681

ST 682

ST 683

ST 684

ST 685

ST 686

ST 687

ST 688

ST 689

ST 690

ST 691

ST 692

ST 693

ST 694

ST 695

ST 696

ST 697

ST 698

ST 699

ST 700

ST 701

ST 702

ST 703

ST 704

ST 705

ST 706

ST 707

0-29 cm, pale brown fine sandy loam; $29-30 \mathrm{~cm}+$, yellowish-brown clay

0-29 cm, pale brown fine sandy loam; $29-30 \mathrm{~cm}+$, yellowish-brown clay (fine sandy loam zone contains historical artifacts, 4 lLN302)

0-57 cm, pale brown fine sandy loam; $57-58 \mathrm{~cm}+$, yellowish-brown clay (fine sandy loam zone contains historical artifacts, 4lLN302)

0-36 cm, pale brown fine sandy loam; $36-37 \mathrm{~cm}+$, yellowish-brown clay

0-69 cm, pale brown fine sandy loam; 69-70 cm+, yellowish-brown clay

0-100 $\mathrm{cm}+$, pale brown fine sandy loam

0-60 cm, pale brown fine sandy loam; 60-62 cm+, yellowish-brown clay (fine sandy loam zone contains historical artifacts, $41 \mathrm{LN} 298$ )

0-50 cm, pale brown fine sandy loam; 50-52 cm+, yellowish-brown clay (fine sandy loam zone contains prehistoric artifacts, 41LN298)

0-5 cm, grayish-brown sandy loam; 5-60 cm, pale brown fine sandy loam; 60-62 cm+, yellowish-brown clay

0-5 cm, grayish-brown sandy loam; 5-60 cm, pale brown fine sandy loam; 60-63 cm+, yellowish-brown clay

0-68 cm, pale brown fine sandy loam; 68-70 cm+, yellowish-brown clay (fine sandy loam zone contains prehistoric artifacts, 4lLN298)

0-15 cm, dark grayish-brown sandy loam; 15-60 cm, pale brown fine sandy loam; 60-64 $\mathrm{cm}+$, yellowish-brown clay (sandy loam and fine sandy loam zones contain historical artifacts, 4lLN298)

0-49 cm, pale brown fine sandy loam; $49-53 \mathrm{~cm}+$, yellowish-brown clay

0-41 cm, pale brown fine sandy loam; 41-42 cm+, yellowish-brown clay

0-72 cm, pale brown fine sandy loam; $72-73 \mathrm{~cm}+$, yellowish-brown clay

$0-103 \mathrm{~cm}+$, pale brown fine sandy loam

0-65 cm, pale brown fine sandy loam; 65-66 cm+, yellowish-brown clay

0-70 cm, pale brown fine sandy loam; 70-71 cm+, yellowish-brown clay

0-100 cm+, pale brown fine sandy loam (fine sandy loam zone contains historical artifacts, 4lLN299)

0-100 cm+, pale brown fine sandy loam (fine sandy loam zone contains prehistoric artifacts, 4lLN299)

0-100 cm+, pale brown fine sandy loam (fine sandy loam zone contains prehistoric artifacts, 4lLN299)

0-102 cm+, pale brown fine sandy loam (fine sandy loam zone contains prehistoric artifacts, $41 \mathrm{LN} 299$ )

0-100 cm, pale brown fine sandy loam (fine sandy loam zone contains prehistoric

artifacts, 4lLN299)

0-100 $\mathrm{cm}+$, pale brown fine sandy loam

0-100 cm+, pale brown fine sandy loam (fine sandy loam zone contains historical artifacts, 4lLN299)

0-102 cm+, pale brown fine sandy loam (fine sandy loam zone contains historical artifacts, 4lLN299)

0-62 cm, pale brown fine sandy loam; $62-63 \mathrm{~cm}+$, yellowish-red clay

0-52 cm, pale brown fine sandy loam; $52-54 \mathrm{~cm}+$, yellowish-red clay 
0-102 cm+, pale brown fine sandy loam (fine sandy loam zone contains historical artifacts, 41LN299)

ST 709

ST 710

ST 711

ST 712

ST 713

ST 714

ST 715

ST 716

ST 717

ST 718

ST 719

ST 720

ST 721

ST 722

ST 723

ST 724

ST 725

ST 726

ST 727

ST 728

ST 729

ST 730

ST 731

ST 732

ST 733

ST 734

ST 735

ST 736

ST 737

ST 738

0-101 $\mathrm{cm}+$, pale brown fine sandy loam

0-42 cm, pale brown fine sandy loam; $42-43 \mathrm{~cm}+$, yellowish-brown clay

0-102 cm+, pale brown fine sandy loam

0-7 cm, grayish-brown sandy loam; 7-77 cm, pale brown fine sandy loam; 77-78 cm+, yellowish-brown clay

0-100 $\mathrm{cm}+$, pale brown fine sandy loam

0-100 cm+, pale brown fine sandy loam (fine sandy loam zone contains paleobotanical materials of likely prehistoric age, 41LN299)

0-10 cm, grayish-brown sandy loam; $10-55 \mathrm{~cm}$, pale brown fine sandy loam; $55-57 \mathrm{~cm}+$, yellowish-brown clay (sandy loam and fine sandy loam zones contain historical artifacts, 41LN300)

0-60 cm, pale brown fine sandy loam; 60-62 cm+, yellowish-brown clay

0-70 cm, pale brown fine sandy loam; 70-72 cm+, yellowish-brown clay (fine sandy loam zone contains historical artifacts, 4 lLN300)

0-92 cm, pale brown fine sandy loam; 90-93 cm+, yellowish-brown clay (fine sandy loam zone contains historical artifacts, $41 \mathrm{LN} 300$ )

0-100 $\mathrm{cm}+$, pale brown fine sandy loam

0-100 $\mathrm{cm}+$, pale brown fine sandy loam

0-16 cm, grayish-brown sandy loam; 16-72 cm, pale brown fine sandy loam; $72-73 \mathrm{~cm}+$, yellowish-brown clay (sandy loam and fine sandy loam zones contain historical artifacts, 41LN300)

0-10 cm, grayish-brown sandy loam; $10-103 \mathrm{~cm}+$, pale brown fine sandy loam (fine sandy loam zone contains historical artifacts, 4lLN300)

0-107 cm+, pale brown fine sandy loam

0-102 $\mathrm{cm}+$, pale brown fine sandy loam

0-69 cm, pale brown fine sandy loam; $69 \mathrm{~cm}+$, yellowish-brown clay

0-100 $\mathrm{cm}+$, pale brown fine sandy loam

0-100 $\mathrm{cm}+$, pale brown fine sandy loam

0-100 $\mathrm{cm}+$, pale brown fine sandy loam

0-100 $\mathrm{cm}+$, pale brown fine sandy loam

0-62 cm, pale brown fine sandy loam; $62-63 \mathrm{~cm}+$, yellowish-brown clay

0-64 cm, pale brown fine sandy loam; 64-68 cm+, yellowish-brown clay

0-100 $\mathrm{cm}+$, pale brown fine sandy loam

0-77 cm, pale brown fine sandy loam; 77-79 cm+, yellowish-brown clay

0-50 cm, pale brown fine sandy loam; 50-52 cm+, yellowish-brown clay (fine sandy loam contains historical artifacts, 4lLN365)

0-38 cm, pale brown fine sandy loam; 38-39 cm+, yellowish-brown clay

0-100 cm+, pale brown fine sandy loam

0-100 cm+, pale brown fine sandy loam

0-100 cm+, pale brown fine sandy loam (fine sandy loam zone contains historical artifacts, 4lLN365) 
ST 739

ST 740

ST 741

ST 742

ST 743

ST 744

ST 745

ST 746

ST 747

ST 748

ST 749

ST 750

ST 751

ST 752

ST 753

ST 754

ST 755

ST 756

ST 757

ST 758

ST 759

ST 760

ST 761

ST 762

ST 763

ST 764

ST 765

ST 766

ST 767

ST 768
0-100 cm+, pale brown fine sandy loam (fine sandy loam zone contains historical artifacts, 4lLN358)

0-100 cm+, pale brown fine sandy loam (fine sandy loam zone contains historical artifacts, 4lLN358)

0-100 $\mathrm{cm}+$, pale brown fine sandy loam

0-106 cm+, pale brown fine sandy loam (fine sandy loam zone contains prehistoric artifacts, 4lLN358)

0-90 cm, pale brown fine sandy loam; $90 \mathrm{~cm}+$, yellowish-brown clay

0-5 cm, very dark grayish-brown sandy loam; 5-29 cm, pale brown fine sandy loam; 29-31 $\mathrm{cm}+$, yellowish-brown clay (sandy loam and fine sandy loam zones contain prehistoric artifacts, 4lLN30l)

0-5 cm, very dark grayish-brown sandy loam; 5-40 cm, pale brown fine sandy loam; 40-42 $\mathrm{cm}+$, yellowish-brown clay

0-5 cm, very dark grayish-brown sandy loam; 5-50 cm, grayish-brown fine sandy loam with yellowish-brown clay mottles; $52 \mathrm{~cm}+$, yellowish-brown clay

0-5 cm, very dark grayish-brown sandy loam; 5-44 cm, pale brown fine sandy loam; 44-46 $\mathrm{cm}+$, yellowish-brown clay

0-5 cm, very dark grayish-brown sandy loam; 5-30 cm, pale brown fine sandy loam; 30-32 $\mathrm{cm}+$, yellowish-brown clay

0-100 cm+, pale brown fine sandy loam

0-40 cm, pale brown fine sandy loam; 40-100 cm+, light gray fine sandy loam

0-29 cm, pale brown fine sandy loam; $29-30 \mathrm{~cm}+$, yellowish-red clay (fine sandy loam zone contains historical artifacts, 4lLN301)

0-42 cm, yellowish-brown fine sandy loam; $42-43 \mathrm{~cm}+$, yellowish-brown clay

0-15 cm, yellowish-brown fine sandy loam; 15-17 cm+, yellowish-brown clay

0-5 cm, very dark grayish-brown sandy loam; 5-100 cm+, yellowish-brown sandy loam (lower sandy loam zone contains prehistoric artifacts, 4lLN304)

0-5 cm, very dark grayish-brown sandy loam; 5-103 cm+, yellowish-brown sandy loam

0-5 cm, very dark grayish-brown sandy loam; 5-101 cm+, yellowish-brown sandy loam

0-100 cm+, yellowish-brown fine sandy loam

0-100 cm+, yellowish-brown fine sandy loam

0-79 cm, yellowish-brown fine sandy loam; 79-82 cm+, yellowish-red clay

0-102 cm+, pale brown fine sandy loam

0-101 $\mathrm{cm}+$, pale brown fine sandy loam

0-100 cm+, pale brown fine sandy loam

0-63 cm, pale brown fine sandy loam; $63 \mathrm{~cm}+$, yellowish-red clay (fine sandy loam zone contains prehistoric artifacts and a possible rock feature [bottom depth of $54 \mathrm{~cm} \mathrm{bs}$ ], 4lLN304)

0-18 cm, yellowish-brown sandy loam; $18-20 \mathrm{~cm}+$, yellowish-brown clay

0-15 cm, disturbed sediments with charcoal; $15-60 \mathrm{~cm}$, pale brown fine sandy loam; 60-62

$\mathrm{cm}+$, yellowish-brown clay

0-5 cm, disturbed sediments; $5-8 \mathrm{~cm}+$, yellowish-brown clay

0-45 cm+, very compact pale brown fine sandy loam (fine sandy loam zone contains prehistoric artifacts, 4lLN363)

0-5 cm, yellowish-brown sandy loam with charcoal; 5-10 cm+, yellowish-brown clay 
ST 769

ST 770

ST 771

ST 772

ST 773

ST 774

ST 775

ST 776

ST 777

ST 778

ST 779

ST 780

ST 781

ST 782

ST 783

ST 784

ST 785

ST 786

ST 787

ST 788

ST 789

ST 790

ST 791

ST 792

ST 793

ST 794

ST 795

ST 796

ST 797

ST 798

ST 799

ST 800

ST 801

ST 802

ST 803
0-88 cm, yellowish-brown sandy loam; $88-90 \mathrm{~cm}+$, yellowish-brown clay

0-38 cm, pale brown sandy loam; 38-39 $\mathrm{cm}+$, yellowish-brown clay

0-28 cm, pale brown sandy loam; $28-30 \mathrm{~cm}+$, yellowish-brown clay

0-17 cm, yellowish-brown sandy loam; 17-18 cm+, yellowish-brown clay

0-36 cm, pale brown sandy loam; $36-37 \mathrm{~cm}+$, yellowish-red clay

0-36 cm, yellowish-brown sandy loam; 36-37 cm+, yellowish-brown clay

0-40 cm, pale brown sandy loam; 40-42 cm+, yellowish-red clay

0-23 cm, pale brown sandy loam; $23 \mathrm{~cm}+$, yellowish-red clay

0-12 cm, grayish-brown sandy loam; 12-77 cm, pale brown sandy loam; $77 \mathrm{~cm}+$, yellowish-brown clay

0-35 cm, disturbed sediments and charcoal; 35-102 cm+, yellowish-brown sandy loam

0-103 cm+, yellowish-brown sandy loam

0-100 cm+, pale brown sandy loam

$0-100 \mathrm{~cm}+$, pale brown sandy loam

0-106 cm+, pale brown sandy loam

0-104 cm+, pale brown sandy loam

0-12 cm, grayish-brown sandy loam; 12-100 cm+, pale brown sandy loam

0-10 cm, grayish-brown sandy loam; 10-100 cm+, pale brown sandy loam (lower sandy loam zone contains prehistoric artifacts, 4lLN364)

0-10 cm, grayish-brown sandy loam; $10-100 \mathrm{~cm}+$, pale brown sandy loam

0-100 $\mathrm{cm}+$, pale brown sandy loam

0-5 cm, grayish-brown sandy loam; 5-7 cm+, yellowish-red clay

$0-5 \mathrm{~cm}+$, yellowish-red clay

$0-5 \mathrm{~cm}+$, red clay

0-40 cm, pale brown fine sandy loam; $40-42 \mathrm{~cm}+$, yellowish-red clay (fine sandy loam zone contains historical artifacts, 4lLN305)

0-42 cm, pale brown fine sandy loam; $42-43 \mathrm{~cm}+$, yellowish-red clay

0-12 cm, pale brown fine sandy loam; $12-15 \mathrm{~cm}+$, red clay

0-10 cm, pale brown fine sandy loam; 10-12 cm+, red clay

0-41 cm, pale brown fine sandy loam; 41-43 cm+, yellowish-red clay (fine sandy loam zone contains historical artifacts, $41 \mathrm{LN} 305)$

0-18 cm, pale brown fine sandy loam; 18-20 cm+, yellowish-red clay

0-40 cm, pale brown fine sandy loam; 40-4l cm+, red clay (fine sandy loam zone contains historical artifacts, 4lLN305)

0-45 cm, pale brown fine sandy loam; $45-46 \mathrm{~cm}+$, red clay (fine sandy loam zone contains historical artifacts, 4lLN305)

0-26 cm, pale brown fine sandy loam; $26-27 \mathrm{~cm}+$, red clay

0-23 cm, pale brown fine sandy loam; $23-24 \mathrm{~cm}+$, red clay

0-17 cm, pale brown fine sandy loam; $17-19 \mathrm{~cm}+$, red clay

0-5 cm, very dark grayish-brown sandy loam; 5-25 cm, pale brown fine sandy loam;

25-27 cm+, yellowish-red clay (sandy loam and fine sandy loam zones contain historical artifacts, 4lLN337)

0-10 cm+, yellowish-red clay 


\begin{tabular}{|c|c|}
\hline ST 804 & $0-5 \mathrm{~cm}+$, yellowish-red clay \\
\hline ST 805 & 0-38 cm, pale brown fine sandy loam; 38-42 cm+, yellowish-red clay \\
\hline ST 806 & 0-47 cm, pale brown fine sandy loam; 47-49 cm+, yellowish-red clay \\
\hline ST 807 & $\begin{array}{l}\text { 0-27 cm, pale brown fine sandy loam; } 27-28 \mathrm{~cm}+\text {, yellowish-red clay (fine sandy loam } \\
\text { zone contains historical artifacts, } 41 \mathrm{LN} 337 \text { ) }\end{array}$ \\
\hline ST 808 & 0-25 cm, pale brown fine sandy loam; $25-26 \mathrm{~cm}+$, yellowish-red clay \\
\hline ST 809 & 0-19 cm, pale brown fine sandy loam; 19-20 cm+, yellowish-red clay \\
\hline ST 810 & 0-25 cm, pale brown fine sandy loam; $25-26 \mathrm{~cm}+$, yellowish-red clay \\
\hline ST 811 & 0-29 cm, pale brown fine sandy loam; $29-30 \mathrm{~cm}+$, red clay \\
\hline ST 812 & 0-38 cm, pale brown fine sandy loam; 38-40 cm+, red clay \\
\hline ST 813 & $\begin{array}{l}\text { 0-10 cm, dark grayish-brown sandy loam; } 10-40 \mathrm{~cm} \text {, light gray fine sandy loam; } 40-42 \\
\mathrm{~cm}+\text {, yellowish-red clay }\end{array}$ \\
\hline ST 814 & $\begin{array}{l}0-10 \mathrm{~cm} \text {, grayish-brown sandy loam; 10-30 cm, yellowish-brown fine sandy loam; 30-32 } \\
\mathrm{cm}+\text {, yellowish-red clay }\end{array}$ \\
\hline ST 815 & $\begin{array}{l}0-5 \mathrm{~cm} \text {, very dark grayish-brown sandy loam; } 5-70 \mathrm{~cm} \text {, yellowish-brown fine sandy loam; } \\
70-72 \mathrm{~cm}+\text {, yellowish-red clay }\end{array}$ \\
\hline ST 816 & $\begin{array}{l}\text { 0-10 cm, grayish-brown sandy loam; 10-90 cm, yellowish-brown fine sandy loam; 90-93 } \\
\mathrm{cm}+\text {, yellowish-red clay }\end{array}$ \\
\hline ST 817 & $\begin{array}{l}0-100 \mathrm{~cm}+\text {, yellowish-brown fine sandy loam (fine sandy loam zone contains prehistoric } \\
\text { artifacts, } 4 \text { lLN340) }\end{array}$ \\
\hline ST 818 & 0-100 cm+, yellowish-brown fine sandy loam \\
\hline ST 819 & 0-37 cm, pale brown fine sandy loam; 37-39 cm+, yellowish-red clay \\
\hline ST 820 & 0-18 cm, pale brown fine sandy loam; $18-22 \mathrm{~cm}+$, yellowish-brown clay \\
\hline ST 821 & 0-16 cm, yellowish-brown fine sandy loam; $16-20 \mathrm{~cm}+$, yellowish-brown clay \\
\hline ST 822 & 0-72 cm, yellowish-brown fine sandy loam; $72-74 \mathrm{~cm}+$, yellowish-brown clay \\
\hline ST 823 & 0-30 cm, pale brown fine sandy loam; $30-32 \mathrm{~cm}+$, yellowish-brown clay \\
\hline ST 824 & $\begin{array}{l}0-100 \mathrm{~cm}+, \text { pale brown fine sandy loam (fine sandy loam zone contains prehistoric } \\
\text { artifacts, } 41 \mathrm{LN} 340 \text { ) }\end{array}$ \\
\hline ST 825 & 0-100 cm+, pale brown fine sandy loam \\
\hline ST 826 & 0-29 cm, pale brown fine sandy loam; $29-30 \mathrm{~cm}+$, yellowish-red clay \\
\hline ST 827 & 0-25 cm, pale brown fine sandy loam; $25-26 \mathrm{~cm}+$, yellowish-brown clay \\
\hline ST 828 & 0-20 cm, yellowish-brown fine sandy loam; $20-21 \mathrm{~cm}+$, yellowish-red clay \\
\hline ST 829 & 0-82 cm, pale brown fine sandy loam; $82-83 \mathrm{~cm}+$, yellowish-brown clay \\
\hline ST 830 & 0-102 cm+, yellowish-brown fine sandy loam \\
\hline ST 831 & 0-104 cm+, pale brown fine sandy loam \\
\hline ST 832 & 0-102 cm+, pale brown fine sandy loam \\
\hline ST 833 & $\begin{array}{l}0-10 \mathrm{~cm} \text {, grayish-brown sandy loam; 10-42 cm, pale brown fine sandy loam; } 42 \mathrm{~cm}+\text {, } \\
\text { yellowish-brown clay }\end{array}$ \\
\hline ST 834 & $\begin{array}{l}\text { 0-12 cm, grayish-brown sandy loam; } 12-92 \mathrm{~cm} \text {, pale brown fine sandy loam; } 92 \mathrm{~cm}+\text {, } \\
\text { yellowish-brown clay }\end{array}$ \\
\hline ST 835 & 0-8 cm, grayish-brown sandy loam; 8-100 cm+, pale brown fine sandy loam \\
\hline ST 836 & 0-8 cm, grayish-brown sandy loam; 8-100 cm+, pale brown fine sandy loam \\
\hline ST 837 & $\begin{array}{l}\text { 0-9 cm, grayish-brown sandy loam; } 9-92 \mathrm{~cm} \text {, pale brown fine sandy loam; } 92 \mathrm{~cm}+\text {, } \\
\text { yellowish-brown clay (fine sandy loam zone contains prehistoric artifacts, } 41 \mathrm{LN} 340 \text { ) }\end{array}$ \\
\hline
\end{tabular}


0-6 cm, grayish-brown sandy loam; 6-74 cm, pale brown fine sandy loam; $74 \mathrm{~cm}+$, yellowish-brown clay

ST 839

ST 840

ST 841

ST 842

ST 843

ST 844

ST 845

ST 846

ST 847

ST 848

ST 849

ST 850

ST 851

ST 852

ST 853

ST 854

ST 855

ST 856

ST 857

ST 858

ST 859

ST 860

ST 861

ST 862

ST 863

ST 864

ST 865

ST 866

ST 867

0-100 $\mathrm{cm}+$, pale brown fine sandy loam

0-102 $\mathrm{cm}+$, pale brown fine sandy loam (fine sandy loam zone contains historical artifacts, 4lLN345)

0-103 cm+, pale brown fine sandy loam (fine sandy loam zone contains animal bones from uncertain historical or prehistoric occupation, 4lLN345)

0-100 $\mathrm{cm}+$, pale brown fine sandy loam

$0-41 \mathrm{~cm}$, pale brown fine sandy loam; $41-43 \mathrm{~cm}+$, yellowish-brown clay

0-100 $\mathrm{cm}+$, pale brown fine sandy loam

0-100 $\mathrm{cm}+$, pale brown fine sandy loam

0-75 cm, pale brown fine sandy loam; 75-77 cm+, yellowish-brown clay (fine sandy loam zone contains historical artifacts, $41 \mathrm{LN} 345)$

0-66 cm, pale brown fine sandy loam; 66-68 cm+, yellowish-brown clay

0-100 cm+, pale brown fine sandy loam (fine sandy loam zone contains historical artifacts, 4lLN345)

0-101 cm+, pale brown fine sandy loam

0-107 cm+, pale brown fine sandy loam

0-102 $\mathrm{cm}+$, pale brown fine sandy loam

0-103 cm+, pale brown fine sandy loam (fine sandy loam zone contains prehistoric artifacts, 4lLN345)

0-37 cm, pale brown fine sandy loam; $37 \mathrm{~cm}+$, yellowish-red clay

0-12 cm, grayish-brown fine sandy loam; $12-46 \mathrm{~cm}$, pale brown fine sandy loam; $46 \mathrm{~cm}+$, yellowish-red clay

0-18 cm, grayish-brown fine sandy loam; $18-100 \mathrm{~cm}+$, pale brown fine sandy loam (fine sandy loam zone contains historical artifacts, $41 \mathrm{LN} 345$ )

0-10 cm, grayish-brown sandy loam; 10-29 cm, pale brown fine sandy loam; $29 \mathrm{~cm}+$, yellowish-red clay

0-6 cm, grayish-brown sandy loam; 6-58 cm, pale brown fine sandy loam; $58 \mathrm{~cm}+$, yellowish-red clay

0-100 cm+, yellowish-brown sandy loam (sandy loam zone contains prehistoric artifacts, 4lLN344)

0-8 cm, dark grayish-brown sandy loam; 8-105 cm+, yellowish-brown sandy loam (lower sandy loam zone contains prehistoric artifacts, $41 \mathrm{LN} 344$ )

0-10 cm, dark grayish-brown sandy loam; 10-102 cm+, yellowish-brown sandy loam

0-5 cm, dark grayish-brown sandy loam; 5-101 cm+, yellowish-brown sandy loam

0-100 cm+, yellowish-brown sandy loam

0-100 cm+, yellowish-brown sandy loam

0-100 cm+, pale brown fine sandy loam (fine sandy loam zone contains prehistoric artifacts, 4lLN344)

0-100 $\mathrm{cm}+$, pale brown fine sandy loam

0-100 $\mathrm{cm}+$, pale brown fine sandy loam

0-97 cm+, pale brown fine sandy loam 
ST 868

ST 869

ST 870

ST 871

ST 872

ST 873

ST 874

ST 875

ST 876

ST 877

ST 878

ST 879

ST 880

ST 881

ST 882

ST 883

ST 884

ST 885

ST 886

ST 887

ST 888

ST 889

ST 890

ST 891

ST 892

ST 893

ST 894

ST 895

ST 896

ST 897
0-108 cm+, pale brown fine sandy loam (fine sandy loam contains prehistoric artifacts, 4lLN344)

0-102 cm+, pale brown fine sandy loam

0-101 cm+, yellowish-brown sandy loam

0-12 cm, grayish-brown sandy loam; $12-105 \mathrm{~cm}+$, pale brown fine sandy loam (fine sandy loam zone contains prehistoric artifacts, 4 lLN344)

0-100 cm+, pale brown fine sandy loam (fine sandy loam zone contains prehistoric artifacts, 4lLN344)

0-13 cm, grayish-brown sandy loam; $13-100 \mathrm{~cm}+$, pale brown fine sandy loam (fine sandy loam zone contains prehistoric artifacts, 4lLN344)

0-10 cm, dark grayish-brown sandy loam; 10-102 cm+, light yellowish-brown sandy loam

0-10 cm, dark grayish-brown sandy loam; 10-99 cm+, yellowish-brown sandy loam

0-10 cm, dark grayish-brown sandy loam; 10-100 cm+, yellowish-brown sandy loam (lower sandy loam zone contains prehistoric artifacts, 4lLN343)

0-10 cm, dark grayish-brown sandy loam; 10-100 cm+, yellowish-brown sandy loam (sandy loam zones contain prehistoric artifacts, 4lLN343)

0-10 cm, dark grayish-brown sandy loam; 10-101 cm+, yellowish-brown sandy loam

0-12 cm, dark grayish-brown sandy loam; $12-100 \mathrm{~cm}+$, yellowish-brown sandy loam

0-100 cm+, dark yellowish-brown sandy loam

0-100 cm+, dark yellowish-brown sandy loam

0-101 cm+, dark yellowish-brown sandy loam

0-100 cm+, dark yellowish-brown sandy loam (sandy loam zone contains prehistoric artifacts, 4lLN343)

0-103 cm+, dark yellowish-brown sandy loam

0-101 cm+, dark yellowish-brown sandy loam

0-102 cm+, dark yellowish-brown sandy loam

0-100 cm+, dark yellowish-brown sandy loam (sandy loam zone contains prehistoric artifacts, 4lLN343)

0-18 cm, grayish-brown sandy loam; 18-100 cm+, dark yellowish-brown sandy loam (lower sandy loam zone contains prehistoric artifacts, 4lLN343)

0-15 cm, grayish-brown sandy loam; 15-100 cm+, dark yellowish-brown sandy loam

(lower sandy loam zone contains prehistoric artifacts, 4lLN343)

0-17 cm, grayish-brown sandy loam; 17-50 cm, yellowish-brown sandy loam; 50-51 cm+, yellowish-brown clay

0-10 cm, grayish-brown sandy loam; 10-60 cm, yellowish-brown sandy loam; 60-62 cm+, yellowish-brown clay

0-100 cm+, yellowish-brown sandy loam

0-5 cm, dark grayish-brown sandy loam; 5-102 cm+, yellowish-brown sandy loam

0-100 cm+, yellowish-brown sandy loam (sandy loam zone contains prehistoric artifacts, 4lLN346)

0-63 cm+, yellowish-brown sandy loam

0-100 cm+, yellowish-brown sandy loam

0-102 cm+, yellowish-brown sandy loam 
ST 898

ST 899

ST 900

ST 901

ST 902

ST 903

ST 904

ST 905

ST 906

ST 907

ST 908

ST 909

ST 910

ST 911

ST 912

ST 913

ST 914

ST 915
0-57 cm, yellowish-brown sandy loam; $57-58 \mathrm{~cm}+$, yellowish-red clay

0-53 cm, yellowish-brown sandy loam; 53-54 cm+, yellowish-brown clay

0-85 cm, yellowish-brown sandy loam; $85-86 \mathrm{~cm}+$, yellowish-brown clay

0-100 cm+, yellowish-brown sandy loam

0-60 cm, yellowish-brown sandy loam; $60-100 \mathrm{~cm}+$, pale brown sandy loam

0-102 cm+, yellowish-brown sandy loam (sandy loam zone contains prehistoric artifacts, 4lLN351)

0-100 cm+, yellowish-brown sandy loam

0-5 cm, dark brown sandy loam; 5-50 cm, yellowish-brown sandy loam; 50-52 cm+, yellowish-brown clay

0-5 cm, dark grayish-brown sandy loam; 5-15 cm, grayish-brown sandy loam; 15-17 cm+, yellowish-red clay

0-104 cm+, yellowish-brown sandy loam

0-100 cm+, yellowish-brown sandy loam (sandy loam zone contains prehistoric artifacts, 4lLN329)

0-102 cm+, yellowish-brown sandy loam

0-10 cm, dark grayish-brown sandy loam; 10-58 cm, yellowish-brown sandy loam; 58-60 $\mathrm{cm}+$, yellowish-brown clay

0-72 cm, yellowish-brown sandy loam; 72-74 cm+, yellowish-brown clay

0-13 cm, grayish-brown sandy loam; 13-100 cm+, yellowish-brown sandy loam

0-5 cm, grayish-brown sandy loam; 5-100 cm+, yellowish-brown sandy loam

0-6 cm, grayish-brown sandy loam; 6-43 cm, yellowish-brown sandy loam; 43-44 cm+, yellowish-brown clay

0-7 cm, grayish-brown sandy loam; 7-103 cm+, yellowish-brown sandy loam 


\section{Appendix 2}

\section{Soil Descriptions, 50 X 50 cm Units}

\begin{tabular}{|c|c|c|}
\hline 4lLN298 & Unit 298 & $\begin{array}{l}0-3 \mathrm{~cm} \text {, very dark grayish-brown fine sandy loam; } 3-21 \mathrm{~cm} \text {, yellowish-brown } \\
\text { fine sandy loam; } 21-58 \mathrm{~cm} \text {, light yellowish-brown fine sandy loam; } 58-60 \mathrm{~cm}+\text {, } \\
\text { yellowish-brown sandy clay }\end{array}$ \\
\hline 4lLN299 & Unit 299 & $\begin{array}{l}0-4 \mathrm{~cm} \text {, grayish-brown fine sandy loam; } 4-100 \mathrm{~cm}+\text {, yellowish-brown fine sandy } \\
\text { loam, with clay lamellae throughout }\end{array}$ \\
\hline $41 \mathrm{LN} 300$ & Unit 300 & $\begin{array}{l}\text { 0-8 cm, very dark grayish-brown fine sandy loam; } 8-28 \mathrm{~cm} \text {, brown fine sandy } \\
\text { loam; } 28-62 \mathrm{~cm} \text {, light yellowish-brown fine sandy loam; } 62 \mathrm{~cm}+\text {, yellowish- } \\
\text { brown sandy clay }\end{array}$ \\
\hline $41 \mathrm{LN} 301$ & Unit 301 & $\begin{array}{l}\text { 0-15 cm, grayish-brown fine sandy loam; } 15-33 \mathrm{~cm} \text {, pale brown fine sandy } \\
\text { loam; 33-37 cm, pale brown fine sandy loam with yellowish-brown clay mottles; } \\
37-40 \mathrm{~cm}+\text {, yellowish-brown sandy clay }\end{array}$ \\
\hline $41 \mathrm{LN} 302$ & Unit 302 & $\begin{array}{l}\text { 0-4 cm, dark grayish-brown fine sandy loam; } 4-20 \mathrm{~cm} \text {, yellowish-brown fine } \\
\text { sandy loam; } 20-30 \mathrm{~cm} \text {, yellow fine sandy loam; } 30 \mathrm{~cm}+\text {, yellowish-brown clay }\end{array}$ \\
\hline $41 \mathrm{LN} 303$ & Unit 303 & 0-30 cm, brown fine sandy loam; 30-100 cm+, yellowish-brown fine sandy loam \\
\hline $41 \mathrm{LN} 304$ & Unit 304 & $\begin{array}{l}\text { 0-5 cm, dark grayish-brown fine sandy loam; } 5-43 \mathrm{~cm} \text {, pale brown fine sandy } \\
\text { loam; 43-100 cm+, reddish-brown fine sandy loam }\end{array}$ \\
\hline $41 \mathrm{LN} 305$ & Unit 305 & $\begin{array}{l}0-2 \mathrm{~cm} \text {, dark grayish-brown fine sandy loam; } 2-12 \mathrm{~cm} \text {, brown fine sandy loam; } \\
12-26 \mathrm{~cm} \text {, pale brown sandy loam; } 26-30 \mathrm{~cm}+\text {, yellowish-red sandy clay }\end{array}$ \\
\hline 41LN306 & Unit 306 & 0-12 cm, very dark gray sandy loam midden; $12 \mathrm{~cm}+$, yellowish-red clay \\
\hline $41 \mathrm{LN} 307$ & Unit 307 & $\begin{array}{l}\text { 0-16 cm, very dark grayish-brown sandy loam midden; } 16-23 \mathrm{~cm} \text {, yellowish- } \\
\text { brown fine sandy loam; } 23-25 \mathrm{~cm}+\text {, yellowish-red clay }\end{array}$ \\
\hline $41 \mathrm{LN} 308$ & Unit 308 & $\begin{array}{l}\text { 0-8 cm, grayish-brown loamy fine sand; } 8-59 \mathrm{~cm} \text {, very dark grayish-brown } \\
\text { loamy fine sand midden; } 59-100 \mathrm{~cm}+\text {, dark yellowish-brown loamy fine sand }\end{array}$ \\
\hline $41 \mathrm{LN} 309$ & Unit 309 & 0-30 cm, yellowish-brown fine sandy loam; $30-32 \mathrm{~cm}+$, red clay \\
\hline $41 \mathrm{LN} 310$ & Unit 310 & $\begin{array}{l}\text { 0-4 cm, dark grayish-brown loamy fine sand; } 4-100 \mathrm{~cm} \text {, light yellowish-brown } \\
\text { loamy fine sand; } 100 \mathrm{~cm}+\text {, strong brown clay }\end{array}$ \\
\hline $41 \mathrm{LN} 311$ & Unit 311 & $\begin{array}{l}0-9 \mathrm{~cm} \text {, strong brown fine sandy loam; } 9-22 \mathrm{~cm} \text {, strong brown fine sandy loam } \\
\text { with bricks; } 22-42 \mathrm{~cm}+\text {, reddish-yellow fine sandy loam }\end{array}$ \\
\hline $41 \mathrm{LN} 312$ & Unit 312 & 0-10 cm, red sandy loam; 10-12 cm+ dark red sandy clay \\
\hline $41 \mathrm{LN} 313$ & Unit 313 & $\begin{array}{l}\text { 0-8 cm, grayish-brown fine sandy loam; } 8-24 \mathrm{~cm} \text {, yellowish-brown fine sandy } \\
\text { loam; } 24-47 \mathrm{~cm} \text {, light yellowish-brown fine sandy loam; } 47-51 \mathrm{~cm}+\text {, strong } \\
\text { brown clay }\end{array}$ \\
\hline $41 \mathrm{LN} 314$ & Unit 314 & $\begin{array}{l}\text { 0-37 cm, yellowish-brown loamy fine sand; } 37-100 \mathrm{~cm}+\text {, light yellowish-brown } \\
\text { loamy fine sand }\end{array}$ \\
\hline $41 \mathrm{LN} 315$ & Unit 315 & $\begin{array}{l}0-8 \mathrm{~cm} \text {, grayish-brown sandy loam; 8-35 cm, yellowish-brown fine sandy loam; } \\
35-100 \mathrm{~cm}+\text {, pale brown sandy loam }\end{array}$ \\
\hline $41 \mathrm{LN} 316$ & Unit 316 & $\begin{array}{l}\text { 0-9 cm, very dark grayish-brown fine sandy loam; } 9-44 \mathrm{~cm} \text {, pale brown fine } \\
\text { sandy loam [Feature } 316-1,30-38 \mathrm{~cm} \text { bs, dark gray fine sandy loam with } \\
\text { charcoal flecking]; } 44 \mathrm{~cm}+\text {, strong brown clay }\end{array}$ \\
\hline $41 \mathrm{LN} 317$ & Unit 317 & $\begin{array}{l}0-18 \mathrm{~cm} \text {, yellowish-brown very fine sand; } 18-42 \mathrm{~cm} \text {, pale brown very fine sand; } \\
42-46 \mathrm{~cm}+\text {, yellowish-brown sandy clay }\end{array}$ \\
\hline
\end{tabular}


4lLN318

Unit 318

41LN319 Unit 319

4lLN320 Unit 320

$41 \mathrm{LN} 321$

$41 \mathrm{LN} 322$

Unit 321

Unit 322

41LN323 Unit 323

41LN324 Unit 324

41LN325

Unit 325

41LN326 Unit 326

41LN327 Unit 327

$41 \mathrm{LN} 328$

41LN329 Unit 329

41LN337 Unit 337

$41 \mathrm{LN} 338$

41LN339 Unit 339

41LN340 Unit 340

41LN341 Unit 341

41LN342 Unit 342

4lLN343 Unit 343

41LN344 Unit 344

41LN345 Unit 345

41LN346 Unit 346
0-8 cm, light brownish-gray loamy fine sand; 8-29 cm, dark yellowish-brown loamy fine sand; $29-80 \mathrm{~cm}$, yellowish-red loamy fine sand; $80-100 \mathrm{~cm}+$, brown loamy fine sand

0-22 cm, yellowish-brown fine sandy loam; 22-28 cm+, yellowish-red sandy clay

0-31 cm, dark yellowish-brown loamy fine sand; $31-41 \mathrm{~cm}$, yellowish-brown loamy fine sand; $41-100 \mathrm{~cm}+$, reddish-yellow loamy fine sand

0-20 cm, yellowish-brown fine sandy loam; $20 \mathrm{~cm}+$, yellowish-red sandy clay 0-15 c, brown sandy loam; 15-51 cm, yellowish-brown sandy loam; 51-52 cm+, yellowish-red sandy clay

0-7 cm, brown fine sandy loam; 7-19 cm, yellowish-brown fine sandy loam; 19-100 $\mathrm{cm}+$, brown sandy loam

0-4 cm, dark grayish-brown loamy fine sand; 4-26 cm, brown fine sandy loam; 26-46 cm, light yellowish-brown fine sandy loam; 46-50 cm+, yellowish-brown sandy clay

0-82 cm, very dark grayish-brown sandy loam midden; 82-100 cm+, dark brown sandy loam

0-3 cm, yellowish-brown loamy fine sand; 3-31 cm, dark yellowish-brown loamy fine sand; $31-100 \mathrm{~cm}+$, yellowish-brown loamy fine sand

0-6 cm, very pale brown fine sandy loam; 6-16 cm, strong brown fine sandy loam; 16-22 cm+, yellowish-red clay

0-15 cm, dark yellowish-brown loamy fine sand; 15-68 cm, yellowish-brown loamy fine sand; $68 \mathrm{~cm}+$, reddish-yellow clay

0-5 cm, dark grayish-brown sandy loam; 5-50 cm, brown sandy loam (lamellae present); 50-100 cm+, yellowish-brown fine sandy loam

0-10 cm, light yellowish-brown fine sandy loam; 10-31 cm, very pale brown fine sandy loam; $31 \mathrm{~cm}+$, strong brown clay

0-4 cm, brown sandy loam; 4-68 cm, brown sandy loam; 68-100 cm+, yellowishbrown fine sandy loam

0-7 cm, dark grayish-brown sandy loam; 7-30 cm, brown fine sandy loam, with lamellae; 30-100 cm+, yellowish-brown sandy loam; lamellae present

0-27 cm, yellowish-brown fine sandy loam; 27-100 cm+, light yellowish-brown fine sandy loam

0-22 cm, very dark grayish-brown sandy loam midden; $22-41 \mathrm{~cm}$, dark grayishbrown sandy loam midden; 41-50 cm+, yellowish-red clay

0-26 cm, brown sandy loam; 26-51 cm, yellowish-brown sandy loam; 51-69 cm, pale brown fine sandy loam; $69-70 \mathrm{~cm}+$, yellowish-red clay

0-15 cm, dark yellowish-brown loamy fine sand; 15-71 cm, brown loamy fine sand; 71-100 $\mathrm{cm}+$, yellowish-brown loamy fine sand

0-10 cm, grayish-brown sandy loam; 10-78 cm, yellowish-brown sandy loam; 78-100 cm+, light yellowish-brown sandy loam

0-28 cm, yellowish-brown loamy fine sand; $28-100 \mathrm{~cm}+$, pale brown loamy fine sand with lamellae

0-7 cm, grayish-brown fine sandy loam; 7-50 cm, brown fine sandy loam; 50$100 \mathrm{~cm}+$, pale brown fine sandy loam 


\begin{tabular}{|c|c|c|}
\hline 41LN347 & Unit 347 & $\begin{array}{l}0-3 \mathrm{~cm} \text {, yellowish-brown fine sandy loam; } 3-46 \mathrm{~cm} \text {, light yellowish-brown fine } \\
\text { sandy loam; } 46-100 \mathrm{~cm}+\text {, pale brown fine sandy loam }\end{array}$ \\
\hline $41 \mathrm{LN} 348$ & Unit 348 & $\begin{array}{l}0-5 \mathrm{~cm} \text {, dark grayish-brown loamy fine sand; } 5-31 \mathrm{~cm} \text {, yellowish-brown loamy } \\
\text { fine sand; } 31-100 \mathrm{~cm}+\text {, light yellowish-brown loamy fine sand }\end{array}$ \\
\hline $41 \mathrm{LN} 349$ & Unit 349 & $\begin{array}{l}0-5 \mathrm{~cm} \text {, dark grayish-brown sandy loam; } 5-29 \mathrm{~cm} \text {, brown sandy loam; } 29-60 \mathrm{~cm} \text {, } \\
\text { yellowish-brown sandy loam; } 60 \mathrm{~cm}+\text {, yellowish-red clay }\end{array}$ \\
\hline $41 \mathrm{LN} 350$ & Unit 350 & $\begin{array}{l}\text { 0-51 cm, yellowish-brown fine sandy loam; } 51-90 \mathrm{~cm} \text {, light yellowish-brown } \\
\text { fine sandy loam; } 90-92 \mathrm{~cm}+\text {, yellowish-brown sandy clay }\end{array}$ \\
\hline 4lLN351 & Unit 351 & 0-90 cm, brown sandy loam; 90-92 cm+, yellowish-red sandy clay \\
\hline $41 \mathrm{LN} 353$ & Unit 353 & $\begin{array}{l}0-8 \mathrm{~cm} \text {, dark grayish-brown loamy fine sand; } 8-37 \mathrm{~cm} \text {, yellowish-brown loamy } \\
\text { fine sand; } 37-100 \mathrm{~cm}+\text {, very pale brown loamy fine sand }\end{array}$ \\
\hline $41 \mathrm{LN} 355$ & Unit 355 & $\begin{array}{l}0-4 \mathrm{~cm} \text {, dark grayish-brown fine sandy loam; } 4-12 \text {, yellowish-brown fine } \\
\text { sandy loam; } 12-26 \mathrm{~cm} \text {, brown to dark brown sandy loam midden; } 26-30 \mathrm{~cm}+\text {, } \\
\text { yellowish-brown sandy clay }\end{array}$ \\
\hline 41LN356 & Unit 356 & $\begin{array}{l}0-5 \mathrm{~cm} \text {, brown fine sandy loam; 5-10 cm, strong brown fine sandy loam; } 10 \\
\mathrm{~cm}+\text {, yellowish-red clay }\end{array}$ \\
\hline 41LN357 & Unit 357 & $\begin{array}{l}0-8 \mathrm{~cm} \text {, dark grayish-brown sandy loam; } 8-50 \mathrm{~cm} \text {, yellowish-brown fine sandy } \\
\text { loam; } 50-52 \mathrm{~cm}+\text {, yellowish-red clay }\end{array}$ \\
\hline 41LN358 & Unit 358 & $\begin{array}{l}\text { 0-9 cm, brown sandy loam; } 9-26 \mathrm{~cm} \text {, yellowish-brown fine sandy loam; } 26-100 \\
\mathrm{~cm}+, \text { pale brown sandy loam }\end{array}$ \\
\hline 4lLN363 & Unit 363 & $\begin{array}{l}0-6 \text {, dark grayish-brown sandy loam; } 6-21 \mathrm{~cm} \text {, yellowish-brown sandy loam; } \\
21-34 \mathrm{~cm} \text {, pale brown fine sand loam; } 34-40 \mathrm{~cm}+\text {, yellowish-red clay }\end{array}$ \\
\hline $41 \mathrm{LN} 364$ & Unit 364 & $\begin{array}{l}\text { 0-2 cm, brown loamy fine sand; } 2-26 \mathrm{~cm} \text {, dark yellowish-brown loamy fine } \\
\text { sand; } 26-100 \mathrm{~cm}+\text {, yellowish-brown loamy fine sand }\end{array}$ \\
\hline $41 \mathrm{LN} 365$ & Unit 365 & $\begin{array}{l}0-10 \mathrm{~cm} \text {, grayish-brown sandy loam; } 10-45 \mathrm{~cm} \text {, brown fine sandy loam; 45-100 } \\
\mathrm{cm}+\text {, pale brown fine sandy loam }\end{array}$ \\
\hline $41 \mathrm{LN}$ & Unit & $\begin{array}{l}\text { 0-25 cm, brown sandy loam; } 25-35 \mathrm{~cm} \text {, dark brown sandy loam midden; 35-55 } \\
\mathrm{cm} \text {, yellowish-brown sandy loam and ash; } 55-60 \mathrm{~cm}+\text {, yellowish-red clay }\end{array}$ \\
\hline
\end{tabular}




\section{Appendix 3}

\section{Artifact Inventory}

41LN298

4lLN299
ST $686,0-20 \mathrm{~cm}$

ST $687,20-40 \mathrm{~cm}$

ST $690,60-70 \mathrm{~cm}$

ST $691,0-20 \mathrm{~cm}$

ST $691,20-40 \mathrm{~cm}$

Unit $298,0-10 \mathrm{~cm}$

Unit $298,30-40 \mathrm{~cm}$

ST $698,0-20 \mathrm{~cm}$

ST $698,20-40 \mathrm{~cm}$

ST $698,40-60 \mathrm{~cm}$

ST $699,20-40 \mathrm{~cm}$

ST $700,0-20 \mathrm{~cm}$

ST $700,40-60 \mathrm{~cm}$

ST $701,20-40 \mathrm{~cm}$

ST $701,60-80 \mathrm{~cm}$

ST 702, 20-40 cm

ST 704, 0-20 cm

ST 705, 0-20 cm

ST 705, 40-60 cm

ST 708, 0-20 cm

ST 714, 20-40 cm

Unit $299,10-20 \mathrm{~cm}$

Unit $299,20-30 \mathrm{~cm}$

Unit $299,30-40 \mathrm{~cm}$

Unit 299, 40-50 cm

Unit 299, 50-60 cm

Unit $299,60-70 \mathrm{~cm}$

Unit $299,80-90 \mathrm{~cm}$

Unit $299,90-100 \mathrm{~cm}$

ST 715, 0-20 cm

ST 717, 0-20 cm
1 wire nail

I non-cortical grayish-brown chert lithic debris

I non-cortical quartzite lithic debris

1 tin can fragment

1 wire nail

1 plain whiteware body sherd; 1 unidentifiable nail shank

1 gray chert lithic debris, non-cortical

1 wire nail; 1 clear bottle glass sherd

1 iron hoop (barrel?) or suspension bar for farm equipment

1 wire nail

1 non-cortical quartzite lithic debris

l non-cortical petrified wood lithic debris; 1 non-cortical quartzite lithic debris

1 charred nutshell; 1 piece of wood charcoal; 1 cortical quartzite lithic debris

1 non-cortical quartzite lithic debris

2 cortical quartzite lithic debris

1 non-cortical gray chert lithic debris

1 aqua window glass sherd

1 tin can fragment; 1 iron piece of farm equipment (with bolt hole attachments); 1 clear machine-made bottle (post-1905)

1 aqua bottle glass sherd

1 iron buckle; 1 clear glass bottle

2 charred nutshells

1 non-cortical petrified wood lithic debris

2 petrified wood lithic debris ( 1 cortical, 1 non-cortical); 1 noncortical gray chert lithic debris

2 non-cortical petrified wood lithic debris

1 cortical gray chert lithic debris

3 charred nutshells; 2 non-cortical petrified wood lithic debris; 1 cortical quartzite lithic debris

3 charred nutshells; 2 pieces of wood charcoal; 1 non-cortical reddish-brown chert lithic debris; 1 cortical petrified wood lithic debris; 1 non-cortical light gray chert lithic debris

1 charred nutshell; 1 piece of wood charcoal; 1 non-cortical quartzite lithic debris

2 pieces of wood charcoal

2 cut nails; 1 plain whiteware base sherd

2 cut nails; 1 cut nail/spike; 1 wire nail 
ST 717, 20-40 cm

ST 717, 40-60 cm

ST 718, 0-20 cm

ST 718, 20-40 cm

ST 721, 0-20 cm

ST 721, 20-40 cm ST $722,20-40 \mathrm{~cm}$

Unit 300, 0-10 cm

Unit 300, 10-20 cm

Unit 300, 20-30 cm

Unit 300, 50-60 cm

$41 \mathrm{LN} 301 \quad$ ST $744,20-31 \mathrm{~cm}$

41LN302

$41 \mathrm{LN} 303$

41LN304
ST 751, 0-20 cm

Unit $301,0-10 \mathrm{~cm}$

Unit 301, 10-20 cm

ST $677,20-40 \mathrm{~cm}$

ST $678,0-20 \mathrm{~cm}$

ST $681,0-20 \mathrm{~cm}$

ST $682,0-20 \mathrm{~cm}$

Unit $302,0-10 \mathrm{~cm}$

Unit 302, 10-20 cm

Unit $302,20-30 \mathrm{~cm}$

ST $667,0-20 \mathrm{~cm}$

ST $668,0-20 \mathrm{~cm}$

ST $670,0-20 \mathrm{~cm}$

ST $670,40-60 \mathrm{~cm}$

Unit $303,0-10 \mathrm{~cm}$

Unit 303, 10-20 cm

Unit 303, 20-30 cm

Unit 303, 30-40 cm

Unit 303, 40-50

ST $754,60-80 \mathrm{~cm}$
1 cut nail/spike; 1 aqua bottle glass sherd; 1 aqua window glass sherd

2 cut nails

1 unidentifiable nail shank; 1 clear bottle glass sherd; 1 brown bottle glass sherd

1 white milk glass sherd

1 brown bottle glass sherd; 1 metal washer; 1 cut nail; 1 wire nail; 1 hand-made brick fragment (Brick type $\mathrm{A}$ )

1 cut nail

1 tin can fragment; 1 hand-made brick fragment

1 aqua window glass sherd; 1 hand-made brick fragment (Brick type A); 1 iron link; 2 cut nails/spikes; 1 wire nail; 1 unidentifiable nail head

1 brown snuff glass lip sherd; 1 aqua bottle glass sherd; 1 aqua window glass sherd; 5 wire nails; 29 cut nails; 2 unidentifiable nail shanks

3 wire nails; 4 cut nails/spikes; 4 unidentifiable nail shanks/heads

1 wire nail

I non-cortical petrified wood lithic debris; 1 non-cortical gray chert lithic debris

1 plain porcelain body sherd

2 wire nails; 1 cupreous button (suspender)

1 unidentifiable nail shank

1 iron fence staple; 1 unidentifiable nail shank

1 cut nail

1 cut nail; 1 olive green bottle glass sherd; 1 aqua window glass sherd

1 plain porcelain base sherd

1 non-cortical quartzite lithic debris; 1 piece of slate; 1 milk glass button

1 piece of lead; 1 wire nail

1 plain ironstone rim sherd

1 clear bottle glass sherd; 1 plain ironstone rim sherd

1 aqua bottle glass sherd

1 amber bottle glass sherd

1 non-cortical yellowish-gray chert lithic debris

1 wire nail; 1 clear bottle glass sherd

1 non-cortical red chert lithic debris; 4 cut nails; 3 wire nails; 1 unidentifiable nail shank

1 wire nail/tack

2 wire nails

1 cut nail; 1 wire nail

1 non-cortical gray chert lithic debris 
ST 763, 40-60 cm

Unit 304, 0-10 cm

41LN305

ST 791, 0-20 cm

ST 791, 20-40 cm

ST 795, 0-20 cm

ST 795, 20-40 cm

ST 797, 0-20 cm

ST 798, 0-20 cm

Unit 305, 0-10 cm

Unit 305, 10-20 cm

4lLN306 Surface

ST $143,0-20 \mathrm{~cm}$

ST $143,20-40 \mathrm{~cm}$

ST $144,0-20 \mathrm{~cm}$

ST 146, 0-20 cm

ST $147,0-20 \mathrm{~cm}$

ST 148, 0-18 cm

ST $150,0-20 \mathrm{~cm}$

Unit 306, 0-10 cm

4lLN307 Surface

ST $136,0-5 \mathrm{~cm}$

ST $137,0-20 \mathrm{~cm}$

ST $138,0-18 \mathrm{~cm}$
1 non-cortical brown chert lithic debris; 3 sandstone rocks, unmodified, possibly associated with rock feature $(0.6 \mathrm{~kg})$

1 cortical brown chert lithic debris

1 zinc fruit jar lid; 1 wire nail; 2 clear bottle glass sherds

1 clear bottle glass (with embossed letters)

2 wire nails

2 plain porcelain body sherds; 1 clear bottle glass sherd; 1 unidentifiable nail shank

1 unidentifiable nail shank

3 clear bottle glass sherds; 1 wire nail

1 white milk glass lid liner sherd; 1 plain whiteware body sherd; 2 aqua bottle glass sherds; 1 clear bottle glass sherd

1 plain whiteware body sherd; 2 wire nails

2 plain porcelain rim sherds; 1 plain ironstone body sherd; 1 amber bottle glass sherd

3 clear bottle glass sherds; 1 purple bottle glass sherd; 1 brown bottle glass sherd; 1 brown snuff glass lip sherd

1 brown snuff glass sherd

1 purple bottle glass sherd; 1 thin and unidentifiable iron strip

1 clear bottle glass sherd; 1 plain whiteware base sherd; 1 red hand-painted whiteware body sherd

1 plain whiteware body sherd; 1 plain whiteware rim sherd; 1 purple bottle glass sherd; 1 wire nail

2 brown snuff glass sherds

1 purple bottle glass sherd; 1 clear bottle glass sherd, with embossed letters; 1 plain porcelain body sherd

1 Bristol glaze stoneware body sherd; 1 brown lead-glazed stoneware body sherd; 3 clear bottle glass sherds; 9 brown bottle glass sherds; 1 purple bottle glass sherd; 1 aqua bottle glass sherd; 1 milk glass decorative rim sherd; 3 plain whiteware rim sherds; 1 plain whiteware body sherd; 1 decalcomania whiteware body sherd; 6 aqua window glass sherds; 5 pieces from unidentified cast iron object with hole for attachment; 1 iron fence staple; 1 wire nail; 1 unidentifiable nail shank

1 plain ironstone body sherd; 1 clear bottle glass sherd; 1 white milk glass rim sherd

1 brown snuff glass lip sherd; 2 brown bottle glass sherds; 2 purple bottle glass sherds; 1 aqua bottle glass sherds; 4 milk glass lid liner sherds; 1 aqua window glass sherd; 3 plain whiteware body sherds

1 brown snuff glass lip sherd; 1 wire nail; 1 plain ironstone body sherd; 2 clear bottle glass sherds; 2 purple bottle glass sherds; 1 aqua window glass sherd

1 cast iron piece with bolt hole; 1 ceramic insulator sherd; 1 wire nail; 2 brown snuff glass sherds; 3 clear bottle glass sherds; 3 purple bottle glass sherds 
Unit 307, 0-10 cm

Unit 307, 10-20 cm

\section{4lLN308 Surface}

ST $363,0-20 \mathrm{~cm}$

ST $363,20-40 \mathrm{~cm}$

ST $363,40-60 \mathrm{~cm}$

ST $363,60-80 \mathrm{~cm}$

ST $363,80-100 \mathrm{~cm}$

ST $364,0-20 \mathrm{~cm}$

ST $364,40-60 \mathrm{~cm}$

ST 364, 60-80 cm

ST $365,0-20 \mathrm{~cm}$

ST $365,20-40 \mathrm{~cm}$

ST $365,60-80 \mathrm{~cm}$

ST $365,80-100 \mathrm{~cm}$

ST $367,20-40 \mathrm{~cm}$

ST $368,0-20 \mathrm{~cm}$

ST $370,0-20 \mathrm{~cm}$

ST $370,20-40 \mathrm{~cm}$

ST $371,0-20 \mathrm{~cm}$

ST $371,20-40 \mathrm{~cm}$

ST 372, 20-40 cm

ST $372,40-60 \mathrm{~cm}$

ST $373,20-40 \mathrm{~cm}$
1 cut nail; 4 wire nails; 5 unidentifiable nail shanks; 1 aquamarine fruit jar glass lid sherd; 1 blue bottle glass sherd; 1 red bottle glass sherd; 10 brown bottle glass sherds; 10 aqua bottle glass sherds; 10 clear bottle glass sherds; 3 purple bottle glass sherds; 1 aqua bottle glass sherd with embossing; 2 plain whiteware body sherds; 1 decalcomania whiteware body sherd; 5 aqua window glass sherds

1 cut nail; 4 wire nails; 1 unidentifiable nail shank; 2 hand-made brick fragments; 1 six-sided ceramic disk; 1 embossed whiteware rim sherd; 1 plain whiteware body sherd; 1 aquamarine bottle glass with embossed letters; 4 clear bottle glass sherds; 1 amber bottle glass sherd; 1 purple bottle glass sherd; 1 brown bottle glass sherd; 3 aqua bottle glass sherds; 3 aqua window glass sherds

1 plain whiteware body sherd; 1 non-cortical brown chert lithic debris; 1 non-cortical gray chert lithic debris

2 petrified wood lithic debris ( 1 cortical, 1 non-cortical)

1 wood charcoal piece; 2 animal bones; 1 burned clay; 2 noncortical petrified wood lithic debris

3 animal bones; 2 charred nutshells; 1 non-cortical light gray chert lithic debris; 1 bone-tempered plain body sherd; 1 bone-tempered parallel brushed body sherd

1 ferruginous sandstone fire-cracked rock $(0.1 \mathrm{~kg}) ; 4$ pieces of animal bone

I non-cortical gray chert lithic debris; 5 pieces of burned clay

1 non-cortical grayish-brown chert lithic debris

1 non-cortical white chert lithic debris

2 charred nutshells

2 brown chert lithic debris (l cortical, 1 non-cortical)

1 engraved grog-tempered body sherd

1 non-cortical light gray chert lithic debris; 1 non-cortical quartzite lithic debris

5 pieces of wood charcoal

1 cortical brown chert lithic debris; 1 non-cortical quartzite lithic debris

1 cortical petrified wood lithic debris

1 non-cortical yellowish-gray chert lithic debris; 1 non-cortical gray chert; 1 gray chert drill fragment

1 non-cortical brownish-gray chert lithic debris; 1 cortical quartzite lithic debris

1 cortical white chert lithic debris

1 multi-platform quartzite core; 1 non-cortical light gray chert lithic debris

1 non-cortical gray chert lithic debris

1 cortical brown chert lithic debris; 1 non-cortical gray chert lithic debris

1 cortical quartzite lithic debris; 1 non-cortical light gray chert lithic debris 
ST $377,80-100 \mathrm{~cm}$

ST $378,80-100 \mathrm{~cm}$

ST $380,0-20 \mathrm{~cm}$

ST 380, 40-60 cm

ST $380,60-80 \mathrm{~cm}$

ST 381, 0-20 cm

ST 381, 40-60 cm

ST 383, 40-60 cm

ST $388,0-20 \mathrm{~cm}$

ST $388,20-40 \mathrm{~cm}$

ST $388,40-60 \mathrm{~cm}$

ST $389,20-40 \mathrm{~cm}$

ST 390, 0-20 cm

ST 390, 20-40 cm

ST 391, 0-20 cm

ST $391,20-40 \mathrm{~cm}$

ST $397,20-40 \mathrm{~cm}$

ST $398,0-20 \mathrm{~cm}$

ST 403, 0-20 cm

ST $403,20-40 \mathrm{~cm}$

ST $403,40-60 \mathrm{~cm}$

ST $403,60-80 \mathrm{~cm}$

ST $403,80-100 \mathrm{~cm}$

ST 404, 0-20 cm

ST $404,20-40 \mathrm{~cm}$

ST $404,40-60 \mathrm{~cm}$

ST $404,60-80 \mathrm{~cm}$

ST 405, 0-20 cm

ST $405,20-28 \mathrm{~cm}$
1 non-cortical light gray chert lithic debris

1 cortical yellowish-gray chert lithic debris; 1 non-cortical dark gray chert lithic debris; 1 non-cortical gray chert lithic debris; 2 cortical petrified wood lithic debris

1 cortical quartzite lithic debris

1 non-cortical petrified wood lithic debris; 1 non-cortical chalcedony lithic debris

I non-cortical yellowish-brown chert lithic debris

1 non-cortical petrified wood lithic debris; 1 plain bone-tempered body sherd

1 plain bone-tempered body sherd

2 non-cortical grayish-brown chert lithic debris

2 non-cortical petrified wood lithic debris

1 non-cortical dark grayish-brown chert lithic debris; 1 non-cortical yellowish-gray chert lithic debris; 1 non-cortical petrified wood lithic debris

1 cortical reddish-brown chert lithic debris; 1 non-cortical petrified wood lithic debris

1 non-cortical gray chert lithic debris; 1 cortical petrified wood lithic debris

1 cortical brown chert lithic debris

1 cortical petrified wood lithic debris; 1 non-cortical gray chert lithic debris

I non-cortical dark brown chert lithic debris

1 non-cortical quartzite lithic debris

1 non-cortical light gray chert lithic debris

1 cortical petrified wood lithic debris; 1 non-cortical grayishbrown chert lithic debris; 1 yellowish-gray chert dart point/drill (cf. Angostura)

1 non-cortical dark brown chert lithic debris; 1 non-cortical dark gray-black chert lithic debris; 2 non-cortical petrified wood lithic debris

1 charred nutshell; 1 animal bone

1 charred nutshell; 1 burned clay piece

4 charred nutshells

1 non-cortical gray chert lithic debris; 1 animal bone

I non-cortical dark gray chert lithic debris

1 non-cortical petrified wood lithic debris; 1 cortical gray chert lithic debris; l charred nutshell

1 non-cortical quartzite lithic debris; 5 animal bones; 5 charred nutshells

1 non-cortical petrified wood lithic debris

1 cortical petrified wood lithic debris; 1 non-cortical grayish-brown chert lithic debris

l cortical petrified wood lithic debris 
ST $406,0-20 \mathrm{~cm}$

ST $407,0-20 \mathrm{~cm}$

ST 409, 0-20 cm

ST $410,0-20 \mathrm{~cm}$

ST $411,0-20 \mathrm{~cm}$

ST $411,20-40 \mathrm{~cm}$

ST 411, 40-52 cm

ST 412, 0-20 cm

ST $412,60-80 \mathrm{~cm}$

Unit $308,0-10 \mathrm{~cm}$

Unit 308, 10-20 cm

Unit 308, 20-30 cm

Unit 308, 30-40 cm

Unit 308, 40-50 cm

Unit 308, 50-60 cm

Unit $308,70-80 \mathrm{~cm}$

Unit 308, 80-90 cm

Unit 308, 90-100 cm

4lLN309 Surface

ST 435, 0-20 cm

ST $438,0-20 \mathrm{~cm}$

ST $438,20-26 \mathrm{~cm}$

ST $439,0-20 \mathrm{~cm}$
1 non-cortical light gray chert lithic debris; 2 grayish-brown chert lithic debris (l cortical, l non-cortical)

1 quartzite mano fragment; 1 non-cortical red chert lithic debris

1 closely-spaced parallel incised grog-tempered body sherd

1 cortical petrified wood lithic debris

1 non-cortical grayish-brown chert lithic debris; 1 non-cortical brownish-gray chert lithic debris

1 quartzite fire-cracked rock $(0.1 \mathrm{~kg}) ; 4$ pieces of wood charcoal; 1 non-cortical gray chert lithic debris; 1 cortical petrified wood lithic debris; 1 Godley dart point, petrified wood

1 non-cortical light gray chert lithic debris; 1 non-cortical white chert lithic debris; 1 cortical quartzite lithic debris; 1 cortical petrified wood lithic debris

1 non-cortical gray chert lithic debris

1 piece of wood charcoal

1 reddish-gray chert bipolar core

2 red chert lithic debris ( 1 cortical, 1 non-cortical); 1 non-cortical gray chert lithic debris; 1 non-cortical grayish-brown chert lithic debris; 2 non-cortical quartzite lithic debris; 5 non-cortical petrified wood lithic debris

5 charred nutshells; 1 piece of wood charcoal; 3 animal bones; 1 cortical quartzite lithic debris; 1 non-cortical light gray chert lithic debris; 1 cortical petrified wood lithic debris

4 charred nutshells; 1 animal bone; 4 petrified wood lithic debris ( 1 cortical, 3 non-cortical)

2 burned clay; 2 plain sandy paste body sherds

1 grog-tempered incised rim sherd

1 charred nutshell

1 non-cortical petrified wood lithic debris; 1 sandstone firecracked rock $(0.28 \mathrm{~kg})$

1 non-cortical petrified wood lithic debris

1 milk glass lid liner sherd; 1 purple bottle glass sherd; 1 plain whiteware body sherd

1 aqua bottle glass sherd; 4 clear bottle glass sherds; 1 brown bottle glass sherd; 1 slate fragment; 1 machine-made brick fragment; 1 tin can lid fragment; 2 wire nails; 1 unidentifiable nail shank

1 animal bone; 1 iron fence staple; 1 plain whiteware body sherd; 1 circular cupreous piece; 1 clear bottle glass sherd; 2 aqua bottle glass sherds; 1 brown bottle glass sherd; 5 aqua window glass sherds; 1 cut nail; 12 wire nails; 5 unidentifiable nail shanks; 1 iron knife blade fragment; I unidentified iron piece with an attached handle

1 animal bone; 1 brown bottle glass sherd; 1 clear bottle glass sherd; 2 wire nails; 2 unidentifiable nail shanks

1 clear bottle glass sherd 
ST $442,0-20 \mathrm{~cm}$

ST $442,20-40 \mathrm{~cm}$

ST $443,0-20 \mathrm{~cm}$

ST 444, 0-20 cm

ST 445, 0-20 cm

Unit 309, 0-10 cm

Unit 309, 10-20 cm

Unit $309,20-30 \mathrm{~cm}$

Unit $309,30-40 \mathrm{~cm}$

$41 \mathrm{LN} 310$

ST $181,0-20 \mathrm{~cm}$

ST $181,60-80 \mathrm{~cm}$

ST $184,0-20 \mathrm{~cm}$

ST $184,40-60 \mathrm{~cm}$

ST $184,80-100 \mathrm{~cm}$

ST $185,0-20 \mathrm{~cm}$

ST $185,20-40 \mathrm{~cm}$

ST $185,40-60 \mathrm{~cm}$

ST $185,80-95 \mathrm{~cm}$

ST $189,20-40 \mathrm{~cm}$

Unit $310,20-30 \mathrm{~cm}$

Unit 310, 30-40 cm

Unit 310, 40-50 cm

Unit 310, 50-60 cm

Unit 310, 80-90 cm

$41 \mathrm{LN} 311$ ST $450,0-15 \mathrm{~cm}$

ST $455,0-20 \mathrm{~cm}$
3 wire nails; 2 iron blades with hook and handle endings; 1 plain whiteware body sherd; 1 clear bottle glass sherd

2 thin cupreous fragments

1 glazed brick fragment; 1 blue annular whiteware body sherd; 1 brown bottle glass sherd; 1 non-cortical petrified wood lithic debris

2 animal bones; 1 cast iron kettle fragment; 1 hand-made brick fragment; 2 cut nails; 1 brown lead-glazed stoneware body sherd; 1 clay marble fragment; 1 olive green bottle glass sherd; 2 clear bottle glass sherds; 1 aqua bottle glass sherd; 7 brown bottle glass sherds; 1 purple bottle glass sherd; 1 purple tableware sherd; 2 plain whiteware body sherds; 1 plain whiteware rim sherd; 1 green transfer-printed whiteware body sherd

1 unidentified cast iron fragment

1 cut nail; 1 plain whiteware rim sherd

1 cut nail; 1 aqua bottle glass sherd; 1 red hand-painted whiteware body sherd

1 animal bone; 1 non-cortical dark brown chert lithic debris; 1 whiteware body sherd with black transfer-printed maker's mark (Royal Arms, post 1837)

1 whiteware body sherd with blue transfer-printed maker's mark 1 non-cortical gray chert lithic debris

1 cortical brown chert lithic debris

1 non-cortical quartzite lithic debris; 1 non-cortical petrified wood lithic debris

1 cortical dark gray chert lithic debris

2 wood charcoal pieces

1 non-cortical petrified wood lithic debris; 3 non-cortical quartzite lithic debris

1 cortical quartzite lithic debris; 1 non-cortical petrified wood lithic debris

1 petrified wood arrow point (cf. Friley)

1 cortical petrified wood lithic debris

I non-cortical gray chert lithic debris; 1 non-cortical light gray chert lithic debris

4 quartzite lithic debris (1 cortical, 3 non-cortical)

1 non-cortical gray chert lithic debris; 1 non-cortical light gray chert lithic debris; 1 cortical petrified wood lithic debris

1 non-cortical brownish-red chert lithic debris

1 non-cortical brownish-gray chert lithic debris; 1 non-cortical quartzite lithic debris; 1 cortical petrified wood lithic debris

1 cortical quartzite lithic debris

8 hand-made brick fragments (Brick type $A$ ); 2 hand-made brick fragments (Brick type B)

6 hand-made brick fragments (Brick type A); 5 hand-made brick fragments (Brick type B) 
Unit 311, 0-10 cm

Unit 311, 10-20 cm

Unit 311, 20-30 cm

41LN312

Surface

ST 169, 0-20 cm

ST $171,0-20 \mathrm{~cm}$

ST $175,0-20 \mathrm{~cm}$

ST $176,0-10 \mathrm{~cm}$

ST $178,0-10 \mathrm{~cm}$

Unit $312,0-10 \mathrm{~cm}$

41LN313

41 LN314
Surface, adjacent to ST 163

ST $154,20-40 \mathrm{~cm}$

ST 155, 0-20 cm

ST 160, 0-20 cm

ST 160, 20-40 cm

ST $163,0-10 \mathrm{~cm}$

ST 164, 0-20 cm

Unit 313, 0-10 cm

Unit 313, 10-20 cm

Unit $313,20-30 \mathrm{~cm}$

ST $257,0-20 \mathrm{~cm}$

ST $257,20-40 \mathrm{~cm}$

ST $257,40-60 \mathrm{~cm}$

ST $258,20-40 \mathrm{~cm}$

ST $263,0-20 \mathrm{~cm}$

ST $269,0-20 \mathrm{~cm}$

ST $271,0-20 \mathrm{~cm}$

ST $271,20-40 \mathrm{~cm}$

ST $271,60-80 \mathrm{~cm}$

ST $273,20-40 \mathrm{~cm}$

ST $274,20-40 \mathrm{~cm}$

Unit 314, 10-20 cm

Unit 314, 20-30 cm

Unit 314, 30-40 cm
4 hand-made brick fragments (Brick type A); 2 hand-made brick fragments (Brick type B)

5 hand-made brick fragments (Brick type A); 1 hand-made brick fragment (Brick type B)

1 hand-made brick fragment (Brick type B)

6 plain whiteware body sherds

9 tin can fragments; 2 aqua window glass sherds

1 clear bottle glass sherd; 1 aqua window glass sherd

1 aqua window glass sherd

1 cast iron piece, possible stove fragment

1 porcelain decalcomania body sherd; 1 aqua window glass sherd 1 multi-platform petrified wood core; 1 white milk glass container sherd; 2 tin can fragments; 1 green bottle glass sherd (with embossed letters); 2 plain whiteware body sherds; 1 plain whiteware base sherd

1 ceramic door knob

1 piece of barbed wire

4 wire nails

1 circular iron piece

2 aqua window glass sherds

1 bright aqua bottle glass sherd

1 blue bottle glass sherd

3 wire nails

1 iron wire; 1 aqua bottle glass sherd; 1 clear bottle glass sherd; 2 aqua window glass sherds

1 donut-shaped green glass bead; 2 clear fruit jar glass sherds; 1 plain whiteware rim sherd; 1 plain whiteware base sherd; 1 aqua window glass sherd

1 plain whiteware body sherd; 1 plain whiteware rim sherd; 1 aqua bottle glass sherd

1 clear bottle glass sherd

1 green bottle glass sherd

1 clear bottle glass sherd, melted

1 clear bottle glass sherd

1 purple tableware glass sherd; 1 plain whiteware body sherd

1 wire nail; 1 brown bottle glass sherd

1 purple bottle glass sherd

1 cut nail

1 clear bottle glass sherd with embossed lettering

1 very thin clear bottle glass sherd

1 plain whiteware rim sherd

1 cortical quartzite lithic debris

1 clear bottle glass sherd 
41 LN315

$41 \mathrm{LN} 316$

41LN317

4lLN318

41LN319
Unit 314, 80-90 cm

Unit 315, 0-10 cm

ST 302, 0-20 cm

ST $309,0-20 \mathrm{~cm}$

Unit $316,10-20 \mathrm{~cm}$

Unit $316,30-40 \mathrm{~cm}$

ST $314,20-40 \mathrm{~cm}$

ST $316,20-40 \mathrm{~cm}$

Unit 317, 10-20 cm

Unit $317,40-50 \mathrm{~cm}$

ST 240, 0-20 cm

ST $240,20-40 \mathrm{~cm}$

ST $241,0-20 \mathrm{~cm}$

ST $241,20-40 \mathrm{~cm}$

ST $243,0-20 \mathrm{~cm}$

ST $245,20-40 \mathrm{~cm}$

Unit 318, 0-10 cm

Unit 318, 10-20 cm

Unit $318,20-30 \mathrm{~cm}$

Unit $318,30-40 \mathrm{~cm}$

Unit 318, 40-50 cm

Unit 318, 50-60 cm

ST 461, 0-20 cm

ST $462,0-20 \mathrm{~cm}$

ST $463,0-20 \mathrm{~cm}$

ST $464,0-19 \mathrm{~cm}$

ST $468,0-20 \mathrm{~cm}$

ST $468,20-40 \mathrm{~cm}$

ST $468,40-52 \mathrm{~cm}$

ST 469, 0-20 cm

ST $470,0-7 \mathrm{~cm}$

ST $472,0-20 \mathrm{~cm}$

ST $476,0-20 \mathrm{~cm}$

ST $477,0-20 \mathrm{~cm}$
1 aqua window glass sherd

1 iron spade with handle

1 non-cortical gray chert lithic debris

3 non-cortical petrified wood lithic debris

1 non-cortical brown chert lithic debris

5 pieces of wood charcoal; 1 cortical petrified wood lithic debris; 1 cortical brownish-gray chert lithic debris; 1 sandstone fire-cracked rock $(0.17 \mathrm{~kg})$

1 petrified wood core fragment

1 cortical petrified wood chunk; 1 non-cortical petrified wood lithic debris

2 pieces of wood charcoal

1 non-cortical quartzite lithic debris

1 wire nail/spike; 1 clear bottle glass sherd; 1 bright green bottle glass sherd

1 brown bottle glass sherd

1 wire nail

1 wire nail

1 plain whiteware rim sherd; 1 wire nail

3 wire nails

1 bright green bottle glass sherd; 1 clear bottle glass sherd; 1 brown bottle glass sherd

2 clear bottle glass sherds; 3 wire nails; 1 piece of thin wire; 1 tin can fragment; 3 brown bottle glass sherds; 1 cupreous 4-hole button (MILLER DALLAS); 2 aqua window glass sherds

2 bright green bottle glass sherds; 1 aqua window glass sherd

1 tin can fragment; 1 plain whiteware body sherd

1 animal bone

1 aqua bottle glass sherd

1 cortical petrified wood lithic debris

1 plain whiteware body sherd; 1 plain whiteware rim sherd

1 iron nut

1 hand-made brick fragment

3 aqua window glass sherds

1 aqua window glass sherd

1 aqua window glass sherd

1 plain whiteware body sherd; 1 clear bottle glass sherd

6 pieces of barbed wire; 1 wire nail; 2 unidentifiable nail shanks

2 clear bottle glass sherds

1 cut nail; 1 brown bottle glass sherd

1 brown bottle glass sherd 
Unit 319, 0-10 cm

Unit 319, 10-20 cm

41LN320

41LN321

ST $356,80-100 \mathrm{~cm}$

ST $359,60-80 \mathrm{~cm}$

Unit $320,0-10 \mathrm{~cm}$

Unit 320, 10-20 cm

ST 539, 0-20 cm
ST 540, 0-13 cm

ST $542,0-16 \mathrm{~cm}$

ST $543,0-20 \mathrm{~cm}$

ST 543, 20-31 cm

ST $544,20-40 \mathrm{~cm}$

ST 545, 0-20 cm

ST $545,51 \mathrm{~cm}$

ST $546,40-60 \mathrm{~cm}$

ST $546,60-80 \mathrm{~cm}$

ST 549, 0-20 cm

ST 550, 40-60 cm

ST $550,80-100 \mathrm{~cm}$

ST 553, 0-20 cm

ST $554,60-80 \mathrm{~cm}$

ST $556,60-80 \mathrm{~cm}$

ST 558, 0-20 cm

ST $558,20-40 \mathrm{~cm}$

ST $560,0-20 \mathrm{~cm}$

ST $572,0-20 \mathrm{~cm}$

ST $572,20-40 \mathrm{~cm}$

ST $573,0-20 \mathrm{~cm}$

ST $573,20-40 \mathrm{~cm}$

ST 575, 0-20 cm

ST $575,40-60 \mathrm{~cm}$

ST $576,80-100 \mathrm{~cm}$

ST 580, 40-47 cm
1 wire nail; 1 unidentifiable nail shank; 1 plain whiteware rim sherd; 1 embossed whiteware body sherd; 1 plain ironstone base sherd; l Bristol glaze/cobalt glaze stoneware body sherd; 1 clear bottle glass lip sherd

5 tin can fragments; 1 plain whiteware body sherd; 1 plain whiteware base sherd; 1 brown bottle glass sherd

l non-cortical grayish-brown chert lithic debris

l sandy paste plain body sherd

1 petrified wood core fragment

1 non-cortical gray chert lithic debris

1 non-cortical light gray chert lithic debris

l non-cortical dark gray chert lithic debris

1 possible plain pearlware body sherd; 1 non-cortical red chert lithic debris; 1 non-cortical dark gray chert lithic debris

l non-cortical brown chert lithic debris; 1 cortical reddish-brown chert lithic debris

1 non-cortical brownish-red chert lithic debris

1 dark gray chert dart point stem

1 brown chert flake tool

1 sandstone fire-cracked rock $(0.08 \mathrm{~kg})$

1 non-cortical grayish-brown chert lithic debris

1 non-cortical gray chert lithic debris

1 non-cortical dark gray chert lithic debris

l non-cortical dark gray chert lithic debris

1 non-cortical white chert lithic debris; 1 non-cortical gray chert lithic debris

1 non-cortical dark brown-black chert lithic debris

I non-cortical petrified wood lithic debris; 1 non-cortical light gray chert lithic debris

I non-cortical brown chert lithic debris

1 cortical dark red chert lithic debris

1 non-cortical dark brown chert lithic debris

2 non-cortical gray chert lithic debris

1 green hand-painted whiteware rim sherd

1 non-cortical light gray chert lithic debris

l non-cortical white chert lithic debris

1 non-cortical brown chert lithic debris; 1 light gray chert lithic debris

I non-cortical light gray chert lithic debris

l non-cortical white chert lithic debris

1 charred nutshell

l non-cortical gray chert lithic debris; 1 non-cortical dark gray chert lithic debris 
ST $581,20-40 \mathrm{~cm}$

ST $581,40-60 \mathrm{~cm}$

ST $581,60-80 \mathrm{~cm}$

ST $583,0-20 \mathrm{~cm}$

ST 585, 40-60 cm

ST $586,40-55 \mathrm{~cm}$

ST $587,0-20 \mathrm{~cm}$

ST $587,20-36 \mathrm{~cm}$

Unit 321, 0-10 cm

Unit $321,10-20 \mathrm{~cm}$

41LN322

41LN323
Surface

ST 415, 0-20 cm

ST 418, 0-20 cm

ST $420,0-20 \mathrm{~cm}$

ST 424, 0-20 cm

ST $431,20-40 \mathrm{~cm}$

ST $432,0-20 \mathrm{~cm}$

ST $433,0-16 \mathrm{~cm}$

Unit $322,0-10 \mathrm{~cm}$

ST $588,20-40 \mathrm{~cm}$

ST $588,60-80 \mathrm{~cm}$

ST $588,80-100 \mathrm{~cm}$

ST $589,40-60 \mathrm{~cm}$

ST 591, 0-20 cm

ST $591,20-40 \mathrm{~cm}$

ST 591, 80-100 cm

ST 593, 0-20 cm

ST 595, 0-20 cm

ST $601,0-20 \mathrm{~cm}$

ST $601,40-60 \mathrm{~cm}$

ST $602,0-20 \mathrm{~cm}$

ST $602,20-40 \mathrm{~cm}$

ST $602,60-80 \mathrm{~cm}$
1 non-cortical gray chert lithic debris; 1 cortical red chert lithic debris

1 non-cortical white chert lithic debris

I non-cortical dark brown chert lithic debris

1 ferruginous sandstone bi-pitted stone

I non-cortical yellow chalcedony lithic debris

1 cortical yellowish-brown chert lithic debris

1 non-cortical red chert lithic debris

23 non-cortical gray chert lithic debris; 2 non-cortical light gray chert lithic debris

1 split quartzite cobble

3 quartzite lithic debris ( 2 cortical, 1 non-cortical)

1 blue hand-painted whiteware rim sherd; 2 plain whiteware body sherds

1 light gray flake tool; 1 burned clay; 1 plain sandy paste body sherd

1 plain whiteware rim sherd

13 wire nails; 1 iron fence staple

3 plain whiteware body sherds; 1 blue shell-edged whiteware rim sherd

1 non-cortical petrified wood lithic debris; 1 dark gray blade gunflint

1 non-cortical brownish-gray lithic debris

2 cast iron kettle fragments

3 wire nails; 1 plain whiteware body sherd; 1 salt-glazed stoneware body sherd; l gray chert blade gunflint

1 cortical brown chert lithic debris

1 non-cortical light gray chert lithic debris; 1 non-cortical petrified wood lithic debris; 2 quartzite lithic debris (1 cortical, 1 noncortical)

1 charred nutshell; 1 cortical gray chert lithic debris

1 cortical quartzite lithic debris

1 non-cortical quartzite lithic debris

1 cortical quartzite lithic debris

1 petrified wood Gary dart point preform

1 cortical quartzite lithic debris

1 non-cortical light gray chert lithic debris; 1 non-cortical dark gray chert lithic debris

1 cortical gray chert lithic debris

1 non-cortical quartzite lithic debris

1 non-cortical gray chert lithic debris

I non-cortical gray chert lithic debris; 1 non-cortical dark brown

chert lithic debris

l non-cortical quartzite lithic debris 
ST 603, 20-40 cm

ST 603, 40-60 cm

ST 606, 0-20 cm

ST $606,60-80 \mathrm{~cm}$

Unit 323, 10-20 cm

Unit 323, 20-30 cm

Unit $323,30-40 \mathrm{~cm}$

Unit 323, 40-50 cm

Unit 323, 50-60 cm

Unit $323,70-80 \mathrm{~cm}$

Unit 323, 80-90 cm

Unit 323, 90-100 cm

41LN324

ST 65, 0-20 cm

ST 65, 20-40 cm

ST $66,0-20 \mathrm{~cm}$

ST 71, 0-20 cm

ST 71, 20-40 cm

ST $72,0-20 \mathrm{~cm}$

ST $72,30 \mathrm{~cm}$

ST 72, 40-60 cm

ST 73, 0-20 cm

ST 74, 0-20 cm

Unit $324,0-10 \mathrm{~cm}$

Unit $324,10-20 \mathrm{~cm}$
1 non-cortical quartzite lithic debris

1 charred nutshell; 1 non-cortical quartzite lithic debris

1 non-cortical quartzite lithic debris; 1 non-cortical gray chert lithic debris

l non-cortical quartzite lithic debris; 1 cortical quartzite lithic debris

1 cortical quartzite lithic debris; 3 non-cortical light gray chert lithic debris

2 cortical quartzite lithic debris

1 charred nutshell; 1 non-cortical quartzite lithic debris; 1 plain sandy paste body sherd

1 charred nutshell; 1 non-cortical petrified wood lithic debris; 2 non-cortical quartzite lithic debris

1 cortical quartzite lithic debris

1 cortical quartzite lithic debris

1 cortical grayish-brown chert lithic debris; 1 non-cortical light gray chert lithic debris; 1 cortical reddish-brown chert lithic debris 1 non-cortical petrified wood lithic debris 1 plain ironstone body sherd

2 pieces of lead/sprue; 1 plain porcelain rim sherd; 1 clear bottle glass sherd

1 brown snuff jar glass sherd; 1 plain whiteware body sherd; 1 cut nail; 1 wire nail

9 bright aquamarine bottle glass sherds; 1 clear bottle glass sherd; 1 plain whiteware rim sherd; 1 green decalcomania whiteware rim sherd

8 bright aquamarine bottle glass sherds; 1 clear tableware glass lip sherd; 1 purple bottle glass sherd; 1 wire nail; 1 plain whiteware body sherd; 1 green decalcomania whiteware body sherd

1 clear bottle glass sherd; 1 aqua bottle glass sherd; 1 aqua window glass sherd

1 plain whiteware body sherd; 1 embossed whiteware rim sherd;

1 green decalcomania whiteware rim sherd; 1 clear bottle glass sherd; 1 aqua window glass sherd

1 aqua window glass sherd; 1 green bottle glass sherd; 1 brown bottle glass sherd; 1 aqua bottle glass sherd; 1 plain whiteware base sherd; 6 wire nails; 1 cut nail; 2 unidentifiable nail shanks 2 brown bottle glass sherds; 1 clear bottle glass sherd 1 iron bracket/handle

1 plain whiteware rim sherd; 1 plain whiteware body sherd; 1 piece of slate; 1 clear bottle glass sherd; 1 aqua bottle glass sherd 1 wire nail; 3 clear bottle glass sherds; 1 plain ironstone body sherd; 1 brown bottle glass sherd 
Unit 324, 20-30 cm

Unit 324, 30-40

Unit $324,40-50 \mathrm{~cm}$

41LN325
ST $608,40-60 \mathrm{~cm}$

ST $608,60-80 \mathrm{~cm}$

ST $608,80-100 \mathrm{~cm}$

ST $609,0-20 \mathrm{~cm}$

ST $609,20-40 \mathrm{~cm}$

ST 609, 40-60 cm

ST $609,60-80 \mathrm{~cm}$

ST $609,80-100 \mathrm{~cm}$

ST 610, 0-20 cm

ST $610,20-40 \mathrm{~cm}$

ST $610,40-60 \mathrm{~cm}$

ST $610,60-80 \mathrm{~cm}$

ST $611,20-40 \mathrm{~cm}$

ST $611,40-60 \mathrm{~cm}$

ST $611,60-80 \mathrm{~cm}$

ST $611,80-100 \mathrm{~cm}$

ST $612,40-60 \mathrm{~cm}$

ST $612,60-80 \mathrm{~cm}$
1 non-cortical quartzite lithic debris; 5 brown bottle glass sherds; 1 plain porcelain rim sherd; 1 plain porcelain body sherd; 1 embossed porcelain rim sherd; 1 stoneware elbow pipe stem and lower bowl sherd; 3 cut nails; 8 wire nails; 5 unidentifiable nail shanks and heads

1 plain porcelain rim sherd; 2 clear bottle glass sherds; 2 brown bottle glass sherds; 3 aqua window glass sherds; 12 wire nails; 1 iron bolt

1 unidentifiable nail shank

2 animal bones; 1 non-cortical yellowish-brown chert lithic debris

3 pieces of wood charcoal; 1 animal bone; 1 non-cortical gray chert lithic debris; 1 non-cortical dark gray chert lithic debris

1 charred nutshell; 1 burned clay; 1 cortical quartzite lithic debris; 2 petrified wood lithic debris ( 1 cortical, 1 non-cortical); 2 plain sandy paste body sherds

1 charred nutshell; 1 animal bone; 1 non-cortical dark gray chert lithic debris; 1 non-cortical dark brown chert lithic debris; 2 petrified wood lithic debris (1 cortical, l non-cortical)

1 non-cortical petrified wood lithic debris

1 charred nutshell; 2 non-cortical gray chert lithic debris

2 charred nutshells

2 charred nutshells; 1 non-cortical gray chert lithic debris

7 charred nutshells; 4 pieces of wood charcoal

1 cortical petrified wood lithic debris

1 non-cortical petrified wood lithic debris; 1 non-cortical red chert lithic debris; 2 non-cortical dark gray chert lithic debris; 1 plain bone-grog-tempered/sandy paste rim sherd

3 charred nutshells; 1 piece of wood charcoal; 1 cortical reddishbrown chert lithic debris; 1 horizontal incised grog-tempered rim sherd

1 charred nutshell; 1 cortical petrified wood lithic debris; 1 noncortical gray chert lithic debris; 1 non-cortical grayish-brown chert lithic debris; 1 non-cortical yellowish-gray chert lithic debris 1 non-cortical brown chert lithic debris; 1 non-cortical gray chert lithic debris; 1 non-cortical quartzite lithic debris

5 charred nutshells; 1 non-cortical dark red chert lithic debris; 1 non-cortical quartzite lithic debris

1 charred nutshell; 1 non-cortical petrified wood lithic debris; 1 grog-tempered incised-brushed body sherd

1 charred nutshell; 1 cortical quartzite lithic debris

I non-cortical light gray chert lithic debris; 1 non-cortical petrified wood lithic debris

2 charred nutshells; 1 non-cortical grayish-white chert lithic debris; 1 non-cortical gray chert lithic debris; 1 plain sandy paste body sherd; 1 gray chert arrow point fragment 
ST $612,80-100 \mathrm{~cm}$

ST $613,20-40 \mathrm{~cm}$

ST $613,40-60 \mathrm{~cm}$

ST $613,80-100 \mathrm{~cm}$

ST $614,60-80 \mathrm{~cm}$

ST $616,40-60 \mathrm{~cm}$

ST $616,60-80 \mathrm{~cm}$

ST $617,40-60 \mathrm{~cm}$

ST $617,60-80 \mathrm{~cm}$

ST $618,40-60 \mathrm{~cm}$

ST $618,60-80 \mathrm{~cm}$

ST $618,80-100 \mathrm{~cm}$

ST $619,0-20 \mathrm{~cm}$

ST $619,20-40 \mathrm{~cm}$

ST $619,60-80 \mathrm{~cm}$

ST $619,80-100 \mathrm{~cm}$

ST $620,0-20 \mathrm{~cm}$

ST $620,20-40 \mathrm{~cm}$

ST $620,40-60 \mathrm{~cm}$

ST $620,60-80 \mathrm{~cm}$

ST 621, 0-20 cm

ST $621,40-60 \mathrm{~cm}$

ST $621,80-100 \mathrm{~cm}$

ST $624,40-60 \mathrm{~cm}$

ST $624,80-100 \mathrm{~cm}$

ST $626,0-20 \mathrm{~cm}$
1 charred nutshell; 1 non-cortical brown chert lithic debris; 1 cortical quartzite lithic debris

1 charred nutshell; 1 cortical quartzite lithic debris

1 charred nutshell

1 charred nutshell; 1 non-cortical petrified wood lithic debris

2 charred nutshells; 1 non-cortical red chert lithic debris

1 non-cortical quartzite lithic debris; 1 non-cortical petrified wood lithic debris

1 non-cortical dark brown chert lithic debris

1 non-cortical gray chert lithic debris; 1 non-cortical red chert lithic debris; 1 non-cortical brown chert lithic debris

l non-cortical brown chert lithic debris; 1 non-cortical quartzite lithic debris; 1 cortical red chert lithic debris

2 charred nutshells; 2 light gray chert lithic debris ( 1 cortical, 1 non-cortical); 1 non-cortical red chert lithic debris; 1 non-cortical petrified wood lithic debris; 1 plain grog-tempered/sandy paste body sherd

1 brown chert flake tool

1 non-cortical dark gray chert lithic debris; 1 non-cortical brownish-gray chert lithic debris; 1 non-cortical gray chert lithic debris

2 olive green bottle glass sherds; 1 non-cortical gray chert lithic debris; 1 non-cortical light gray chert lithic debris

2 non-cortical gray chert lithic debris; 1 non-cortical light gray chert lithic debris

1 olive green bottle glass sherd

1 cortical petrified wood lithic debris

1 cortical dark gray chert lithic debris; 1 non-cortical petrified wood lithic debris

1 grayish-brown chert arrow point tip/blade

1 non-cortical petrified wood lithic debris; 1 cortical gray chert lithic debris

1 cortical brown chert lithic debris; 1 non-cortical brownish-gray chert lithic debris

1 quartzite mano

1 non-cortical gray chert lithic debris; 1 bone-tempered sandy paste plain base sherd

1 cortical quartzite lithic debris; 1 non-cortical gray chert lithic debris; 1 plain base sherd

l cortical red chert lithic debris; 1 non-cortical brownish-gray chert

1 grog-hematite-tempered/sandy paste plain base sherd 1 non-cortical gray chert lithic debris; 1 plain sandy paste rim sherd; 2 grog-tempered/sandy paste plain body sherds 
ST $626,80-100 \mathrm{~cm}$

ST $627,0-20 \mathrm{~cm}$

ST $627,40-60 \mathrm{~cm}$

ST 628, 0-20 cm

ST 629, 0-20 cm

ST $629,40-60 \mathrm{~cm}$

ST 630, 0-20 cm

ST 631, 0-20 cm

ST 632, 0-20 cm

ST $632,40-60 \mathrm{~cm}$

ST $635,0-20 \mathrm{~cm}$

ST $635,20-40 \mathrm{~cm}$

ST $635,40-60 \mathrm{~cm}$

ST 636, 0-20 cm

ST $636,20-40 \mathrm{~cm}$

ST $636,40-60 \mathrm{~cm}$

ST $636,60-80 \mathrm{~cm}$

ST $638,0-20 \mathrm{~cm}$

ST $638,20-40 \mathrm{~cm}$

ST $638,40-60 \mathrm{~cm}$

ST $638,60-80 \mathrm{~cm}$

ST $639,0-20 \mathrm{~cm}$

ST $639,20-40 \mathrm{~cm}$

ST $639,40-60 \mathrm{~cm}$

ST $642,40-60 \mathrm{~cm}$
1 non-cortical dark gray chert lithic debris; 1 non-cortical light gray chert lithic debris

1 animal bone; 1 non-cortical quartzite lithic debris; 1 non-cortical red chert lithic debris; 1 non-cortical light gray chert lithic debris; 1 non-cortical gray chert lithic debris; 1 non-cortical petrified wood lithic debris; 1 grog-hematite-tempered/sandy paste plain body sherd

2 non-cortical dark gray chert lithic debris; 2 non-cortical gray chert lithic debris

l cortical gray chert lithic debris; 1 cortical petrified wood lithic debris; 1 plain bone-tempered/sandy paste rim sherd

1 non-cortical dark brown chert lithic debris; 1 cortical light gray chert lithic debris

I non-cortical gray chert lithic debris

1 cortical yellowish-brown chert lithic debris

I non-cortical grayish-brown chert lithic debris

1 non-cortical petrified wood lithic debris; 1 non-cortical gray chert lithic debris

1 cortical quartzite lithic debris; 1 non-cortical brownish-gray chert lithic debris

3 charred nutshells; 2 animal bones; 2 non-cortical light gray chert lithic debris

7 charred nutshells; 2 petrified wood lithic debris ( 1 cortical, 1 noncortical); 1 non-cortical gray chert lithic debris

2 animal bones; 1 non-cortical dark gray chert lithic debris; 2 petrified wood lithic debris (l cortical, l non-cortical)

2 non-cortical gray chert lithic debris

1 charred nutshell; 1 non-cortical petrified wood lithic debris

3 burned clay; 2 charred nutshells; 1 non-cortical petrified wood lithic debris; 1 non-cortical red chert lithic debris

1 charred nutshell; 1 cortical quartzite lithic debris

l non-cortical dark gray chert lithic debris

1 non-cortical gray chert lithic debris; 1 light gray core fragment; 1 grog-tempered incised body sherd

4 charred nutshells; 2 gray chert lithic debris ( 1 cortical, 1 noncortical); 1 plain grog-tempered/sandy paste body sherd

1 non-cortical light gray chert lithic debris; 1 sandstone firecracked rock $(0.06 \mathrm{~kg})$

1 non-cortical light gray chert lithic debris; 1 non-cortical gray chert lithic debris

3 charred nutshells; 2 non-cortical brownish-gray chert lithic debris

2 charred nutshells; 1 non-cortical petrified wood lithic debris; 1 non-cortical light gray chert lithic debris; 1 non-cortical dark brown chert lithic debris; 1 non-cortical quartzite lithic debris

2 non-cortical gray chert lithic debris 
ST $643,0-20 \mathrm{~cm}$

ST $643,20-40 \mathrm{~cm}$

Unit 325, 0-10 cm

Unit 325, 10-20 cm

Unit 325, 20-30 cm

Unit 325, 30-40 cm

Unit $325,40-50 \mathrm{~cm}$

Unity $325,50-60 \mathrm{~cm}$ Unit 325, 60-70 cm

Unit $325,70-80 \mathrm{~cm}$

Unit 325, 80-90 cm

Unit $325,90-100 \mathrm{~cm}$

$41 \mathrm{LN} 326$

41LN327

41LN328
ST $657,60-80 \mathrm{~cm}$

ST $657,80-100 \mathrm{~cm}$

ST $658,80-100 \mathrm{~cm}$

ST $661,20-40 \mathrm{~cm}$

Unit 326, 50-60 cm

Unit $326,60-70 \mathrm{~cm}$

Unit $326,80-90 \mathrm{~cm}$

ST $328,0-20 \mathrm{~cm}$

ST $333,0-20 \mathrm{~cm}$

ST 336, 0-20 cm

Unit $327,0-10 \mathrm{~cm}$

Unit $327,10-20 \mathrm{~cm}$

ST $527,80-100 \mathrm{~cm}$
1 non-cortical white chert lithic debris; 1 non-cortical petrified wood lithic debris

1 non-cortical quartzite lithic debris

1 animal bone; 1 piece of wood charcoal; 1 aqua window glass sherd; 1 non-cortical chalcedony lithic debris; 1 plain bonetempered body sherd

15 animal bones; 2 pieces of wood charcoal; 1 non-cortical petrified wood lithic debris; 1 cortical brown chert lithic debris

3 burned clay; 1 piece of wood charcoal; 1 grog-tempered incised body sherd; 1 non-cortical dark gray chert lithic debris; 1 noncortical reddish-gray chert lithic debris; 1 non-cortical gray chert lithic debris; 1 cortical brown chert lithic debris; 1 non-cortical petrified wood lithic debris

2 burned clay; 1 charred nutshells; 1 cortical brown chert lithic debris

2 charred nutshells; 3 burned clay; 5 animal bones/teeth; 2 petrified wood lithic debris (1 cortical, 1 non-cortical); 1 cortical quartzite lithic debris; 1 non-cortical gray chert lithic debris; 1 sandstone fire-cracked rock $(0.04 \mathrm{~kg})$

1 charred nutshell; 3 animal bones; 1 cortical quartzite lithic debris 2 charred nutshells; 5 pieces of wood charcoal; 3 animal bones 4 burned clay; 4 charred nutshells; 1 piece of wood charcoal; 1 cortical brown chert lithic debris; 1 non-cortical gray chert lithic debris

4 charred nutshells; 2 pieces of wood charcoal; 1 cortical quartzite lithic debris; 1 cortical gray chert lithic debris

3 charred nutshells; 1 piece of wood charcoal; 1 unilateral retouched flake tool, grayish-brown chert; 1 sandstone fire-cracked rock $(0.03 \mathrm{~kg})$

1 non-cortical gray chert lithic debris

1 cortical quartzite lithic debris

1 non-cortical quartzite lithic debris; 1 sandstone fire-cracked rock $(0.02 \mathrm{~kg})$

1 non-cortical gray chert lithic debris

1 cortical petrified wood lithic debris

1 cortical petrified wood lithic debris

1 charred nutshell

1 cortical petrified wood lithic debris

l non-cortical petrified wood lithic debris; 1 cortical brownish-gray chert lithic debris

1 non-cortical gray chert lithic debris

1 non-cortical brown chert lithic debris

1 non-cortical quartzite lithic debris

1 non-cortical quartzite lithic debris; 1 non-cortical light gray chert lithic debris 
ST 533, 20-40 cm

Unit $328,40-50 \mathrm{~cm}$

$41 \mathrm{LN} 329$

$41 \mathrm{LN} 338$

$41 \mathrm{LN} 339$

$41 \mathrm{LN} 340$

4lLN341 Surface

ST $78,0-20 \mathrm{~cm}$

ST $78,20-40 \mathrm{~cm}$

ST $78,40-60 \mathrm{~cm}$

ST 79, 0-20 cm

ST $79,20-40 \mathrm{~cm}$

ST $79,60-75 \mathrm{~cm}$
I non-cortical chalcedony lithic debris; 1 non-cortical gray chert lithic debris

1 cortical quartzite lithic debris

2 brown chert lithic debris ( 1 cortical, 1 non-cortical)

1 cortical quartzite lithic debris

1 non-cortical petrified wood lithic debris

2 clear bottle glass sherds; 1 plain ironstone body sherd

1 blue Fiesta ware body sherd

1 tin can fragment; 1 plain whiteware rim sherd

1 piece of wood charcoal; 1 cortical petrified wood lithic debris

1 non-cortical petrified wood lithic debris; 1 piece of wood charcoal

2 non-cortical quartzite lithic debris

1 non-cortical yellowish-gray chert lithic debris

1 non-cortical brown chert lithic debris

1 non-cortical gray chert lithic debris; 3 quartzite lithic debris (2 cortical, 1 non-cortical)

2 quartzite lithic debris ( 1 cortical, 1 non-cortical); 1 sandstone firecracked rock $(0.04 \mathrm{~kg})$

1 cortical quartzite lithic debris

3 sandstone fire-cracked rock $(0.24 \mathrm{~kg})$

1 cortical brown chert lithic debris; 2 sandstone fire-cracked rocks $(0.14 \mathrm{~kg})$

1 sandstone fire-cracked rock $(0.09 \mathrm{~kg})$

1 non-cortical quartzite lithic debris

2 quartzite lithic debris (1 cortical, 1 non-cortical)

1 non-cortical quartzite lithic debris

3 quartzite lithic debris ( 1 cortical, 2 non-cortical)

2 charred nutshells

1 cortical brownish-gray chert lithic debris; 1 sandstone firecracked rock $(0.09 \mathrm{~kg})$

1 brownish-gray chert dart point fragment; 1 non-cortical light gray chert lithic debris; 1 non-cortical quartzite lithic debris; 1 noncortical dark brown chert lithic debris

1 cortical brownish-yellow chert lithic debris

1 non-cortical gray chert lithic debris; 1 non-cortical grayish-brown chert lithic debris

1 non-cortical yellowish-brown chert lithic debris; 1 cortical bluishgray chert lithic debris; 2 cortical quartzite lithic debris

3 quartzite lithic debris ( 1 cortical, 2 non-cortical); 1 plain sandy paste body sherd

I non-cortical grayish-brown chert lithic debris; 1 charred nutshell 1 non-cortical quartzite lithic debris; 1 plain sandy paste body sherd 
ST $83,20-40 \mathrm{~cm}$

ST $87,0-20 \mathrm{~cm}$

ST $90,60-80 \mathrm{~cm}$

ST $90,80-100 \mathrm{~cm}$

ST 93, 0-20 cm

ST $95,11 \mathrm{~cm}$

ST 99, 0-20 cm

ST $100,0-20 \mathrm{~cm}$

ST $100,20-40 \mathrm{~cm}$

ST $100,40-43 \mathrm{~cm}$

ST 101, 0-20 cm

Unit $341,0-10 \mathrm{~cm}$

Unit 341, 10-20 cm

Unit $341,20-30 \mathrm{~cm}$

Unit $341,30-40 \mathrm{~cm}$

Unit 341, 40-50 cm

41LN342

$41 \mathrm{LN} 343$

Unit $342,50-60 \mathrm{~cm}$

Unit $342,60-70 \mathrm{~cm}$
1 non-cortical dark gray chert lithic debris

1 non-cortical brownish-gray chert lithic debris

1 plain sandy paste body sherd

1 non-cortical gray chert lithic debris

1 plain sandy paste body sherd

1 parallel brushed grog-tempered body sherd

1 non-cortical grayish-brown chert lithic debris

1 non-cortical chalcedony lithic debris; 2 quartzite lithic debris ( 1 cortical, 1 non-cortical); 2 petrified wood lithic debris ( 1 cortical, 1 non-cortical)

1 quartzite core fragment; 1 cortical red chert lithic debris; 1 noncortical yellow chert lithic debris; 1 non-cortical quartzite lithic debris

1 non-cortical petrified wood lithic debris

1 non-cortical dark gray chert lithic debris; 1 quartzite fire-cracked rock $(0.1 \mathrm{~kg})$

2 non-cortical dark gray chert lithic debris; 1 petrified wood tested cobble; 1 cortical petrified wood lithic debris

1 burned clay; 1 non-cortical gray chert lithic debris; 2 quartzite lithic debris (1 cortical, l non-cortical)

1 plain sandy paste rim sherd; 1 non-cortical gray chert lithic debris; 1 non-cortical brown chert lithic debris; 1 cortical red chert lithic debris; 2 non-cortical petrified wood lithic debris; 6 quartzite lithic debris (4 cortical, 2 non-cortical); 1 sandstone fire-cracked rock $(0.05 \mathrm{~kg})$

1 cortical quartzite lithic debris

2 petrified wood lithic debris ( 1 cortical, 1 non-cortical)

1 plain ironstone body/base sherd

1 non-cortical grayish-brown chert lithic debris

4 sandstone fire-cracked rocks $(0.4 \mathrm{~kg})$

1 non-cortical quartzite lithic debris; 4 sandstone fire-cracked rocks $(0.2 \mathrm{~kg})$

2 charred nutshells; 1 cortical quartzite lithic debris; 1 non-cortical gray chert lithic debris

1 reddish-brown multiple platform core

3 charred nutshells; 1 cortical gray chert lithic debris

1 non-cortical dark grayish-black lithic debris; 1 plain grog/sandy paste body sherd

ST $883,60-80 \mathrm{~cm}$

ST $887,0-20 \mathrm{~cm}$

ST $887,40-60 \mathrm{~cm}$

ST $888,80-100 \mathrm{~cm}$
1 cortical gray chert lithic debris; 1 non-cortical petrified wood lithic debris

1 non-cortical dark gray chert lithic debris; 1 non-cortical light gray chert lithic debris

3 non-cortical gray chert lithic debris; 1 non-cortical quartzite lithic debris

l charred nutshell; 1 non-cortical gray chert lithic debris 
ST $889,20-40 \mathrm{~cm}$

ST $889,40-60 \mathrm{~cm}$

ST $889,60-80 \mathrm{~cm}$

ST $889,80-100 \mathrm{~cm}$

Unit $343,20-30 \mathrm{~cm}$

Unit $343,30-40 \mathrm{~cm}$

Unit 343, 40-50 cm

Unit $343,50-60 \mathrm{~cm}$

Unit $343,60-70 \mathrm{~cm}$

Unit $343,70-80 \mathrm{~cm}$

Unit $343,80-90 \mathrm{~cm}$

Unit $343,90-100 \mathrm{~cm}$

$41 \mathrm{LN} 344$

41LN345
ST $858,80-100 \mathrm{~cm}$

ST $859,20-40 \mathrm{~cm}$

ST $859,60-80 \mathrm{~cm}$

ST $864,20-40 \mathrm{~cm}$

ST $864,80-100 \mathrm{~cm}$

ST $868,80-100 \mathrm{~cm}$

ST $871,60-80 \mathrm{~cm}$

ST $872,0-20 \mathrm{~cm}$

ST $873,40-60 \mathrm{~cm}$

ST $873,80-100 \mathrm{~cm}$

Unit $344,20-30 \mathrm{~cm}$

Unit $344,30-40 \mathrm{~cm}$

Unit $344,40-50 \mathrm{~cm}$

Unit $344,60-70 \mathrm{~cm}$

Unit $344,70-80 \mathrm{~cm}$

Unit $344,80-90 \mathrm{~cm}$

Unit $344,90-100 \mathrm{~cm}$

ST $840,60-80 \mathrm{~cm}$
1 charred nutshell; 1 non-cortical gray chert lithic debris; 1 noncortical brown chert lithic debris

2 charred nutshells; 1 non-cortical quartzite lithic debris; 1 cortical brown chert lithic debris; 1 non-cortical gray chert lithic debris

3 charred nutshells; 5 pieces of wood charcoal; 2 burned animal bones; 1 non-cortical gray chert lithic debris

1 burned clay; 2 charred nutshells; 1 piece of wood charcoal; 3 noncortical petrified wood lithic debris

1 charred nutshell; 1 animal bone; 1 cortical petrified wood lithic debris; 1 non-cortical chalcedony lithic debris

9 charred nutshells; 1 piece of wood charcoal; 1 cortical quartzite lithic debris; 2 red chert lithic debris (1 cortical, 1 non-cortical); 2 petrified wood lithic debris ( 1 cortical, 1 non-cortical)

13 charred nutshells; 3 pieces of wood charcoal; 1 non-cortical light gray chert lithic debris; 1 non-cortical petrified wood lithic debris

6 charred nutshells; 1 cortical dark brown chert lithic debris

6 charred nutshells; 1 piece of wood charcoal; 1 non-cortical gray chert lithic debris; 1 cortical dark gray chert lithic debris; 3 sandstone fire-cracked rocks $(0.12 \mathrm{~kg})$

4 charred nutshells; 1 piece of wood charcoal; 1 non-cortical petrified wood lithic debris; 1 sandstone fire-cracked rock $(0.03$ $\mathrm{kg}$ )

1 charred nutshell; 3 pieces of wood charcoal; 1 cortical brown chert lithic debris; 1 non-cortical petrified wood lithic debris; 1 non-cortical gray chert lithic debris

l charred nutshell; 1 non-cortical reddish-brown chert lithic debris;

1 charred nutshell; 1 non-cortical gray chert lithic debris

1 non-cortical petrified wood lithic debris

1 piece of wood charcoal

1 non-cortical gray chert lithic debris

1 cortical dark grayish-brown chert lithic debris

1 non-cortical quartzite lithic debris

1 non-cortical dark gray chert lithic debris

1 cortical petrified wood lithic debris

1 non-cortical quartzite lithic debris

1 non-cortical light gray chert lithic debris

1 piece of wood charcoal; 1 non-cortical gray chert lithic debris

2 pieces of wood charcoal

1 nutshell

1 piece of wood charcoal

1 piece of wood charcoal

1 piece of wood charcoal; 1 non-cortical quartzite lithic debris

1 non-cortical petrified wood lithic debris

1 unidentifiable nail shank 
ST 841, 20-40 cm

ST $846,20-40 \mathrm{~cm}$

ST $848,0-20 \mathrm{~cm}$

ST $848,20-40 \mathrm{~cm}$

ST $852,80-100 \mathrm{~cm}$

ST 855, 20-40 cm

Unit 345, 0-10 cm

Unit 345, 10-20 cm

Unit $345,20-30 \mathrm{~cm}$

Unit 345, 30-40 cm

Unit 345, 40-50 cm

Unit 345, 50-60 cm

Unit 345, 70-80 cm

Unit 345, 90-100 cm

41LN346

41LN347

41LN348

41LN349
ST $894,20-40 \mathrm{~cm}$

Unit 346, 90-100 cm

ST $121,0-20 \mathrm{~cm}$

ST 121, 40-60 cm

ST $123,80-100 \mathrm{~cm}$

ST $125,80-100 \mathrm{~cm}$

Unit $347,20-30 \mathrm{~cm}$

Unit $347,30-40 \mathrm{~cm}$

Unit $347,50-60 \mathrm{~cm}$

Unit 347, 70-80 cm

Unit 347, 80-90 cm

ST 51, 40-60 cm

ST 53, 20-40 cm

Unit 348, 50-60 cm

Unit $348,60-70 \mathrm{~cm}$

Unit 348, 80-90 cm

Unit $348,90-100 \mathrm{~cm}$

ST $28,20-40 \mathrm{~cm}$

ST $28,40-55 \mathrm{~cm}$

ST $39,30 \mathrm{~cm}$

Unit 349, 30-40 cm
7 pieces of unburned animal bone

1 cut nail

1 olive green bottle glass sherd

2 cut nails

1 non-cortical gray chert lithic debris

1 cut nail

1 cut nail; 1 Bristol glaze stoneware/cobalt body sherd

1 non-cortical petrified wood lithic debris

1 unidentifiable nail shank

1 cast iron fragment; 1 olive green bottle glass lip sherd; 2

sandstone fire-cracked rocks $(0.28 \mathrm{~kg})$

2 cut nails; 3 hand-made brick fragments

3 hand-made brick fragments

1 cut nail

1 hand-made brick fragment; 1 non-cortical brownish-gray chert lithic debris

1 non-cortical gray chert lithic debris

1 piece of wood charcoal; 1 non-cortical brown chert lithic debris; 1 non-cortical quartzite lithic debris

1 non-cortical light gray chert lithic debris

1 non-cortical dark grayish-brown chert lithic debris

l non-cortical dark grayish-brown chert lithic debris

1 non-cortical gray chert lithic debris

1 cut nail; 1 non-cortical petrified wood lithic debris

1 non-cortical petrified wood lithic debris

2 non-cortical gray chert lithic debris; 3 sandstone fire-cracked rocks $(0.47 \mathrm{~kg})$

1 non-cortical gray chert lithic debris; 1 ferruginous sandstone mano; 2 sandstone fire-cracked rocks $(0.18 \mathrm{~kg})$

1 non-cortical petrified wood lithic debris; 1 non-cortical gray chert lithic debris

2 non-cortical quartzite lithic debris

2 petrified wood lithic debris ( 1 cortical, 1 non-cortical)

1 non-cortical quartzite lithic debris

1 piece of wood charcoal; 1 charred nutshell; 1 non-cortical quartzite lithic debris

3 charred nutshells; 1 cortical petrified wood lithic debris

2 charred nutshells

1 cortical gray chert lithic debris

1 non-cortical light gray chert lithic debris; 1 cortical quartzite chunk

1 gray chert dart point stem (parallel stem, flat base)

1 non-cortical petrified wood lithic debris 
Unit $349,40-50 \mathrm{~cm}$

Unit 349, 50-60 cm

$41 \mathrm{LN} 350$

4lLN353

4lLN355

ST $478,0-20 \mathrm{~cm}$

ST $479,0-20 \mathrm{~cm}$

ST $482,0-20 \mathrm{~cm}$

ST 486, 0-20 cm

ST $488,0-20 \mathrm{~cm}$

ST $488,20-32 \mathrm{~cm}$

ST 490, 0-20 cm

Unit 355, 0-10 cm

Unit 355, 10-20 cm

Unit 355, 20-30 cm

41 LN356 ST 494, 0-15 cm

ST 495, 0-10 cm
7 sandstone fire-cracked rocks $(0.7 \mathrm{~kg})$

3 pieces of wood charcoal; 1 cortical brownish-gray chert lithic debris

1 cortical quartzite lithic debris

1 non-cortical quartzite lithic debris

1 non-cortical quartzite lithic debris

1 non-cortical quartzite lithic debris

1 non-cortical grayish-brown chert lithic debris

3 pieces of wood charcoal; 1 cortical quartzite lithic debris

1 cortical petrified wood lithic debris; 1 non-cortical quartzite lithic debris

1 iron fence staple

1 petrified wood biface fragment

1 non-cortical quartzite lithic debris

1 wire nail

3 wire nails; 1 unidentifiable nail shank; 1 piece of wire

30 clear bottle glass sherds; 2 clear bottle glass sherds with embossed letter

6 clear bottle glass sherd

2 clear bottle glass sherds

14 clear bottle glass sherds

10 wire nails; 1 piece of iron wire; 42 clear bottle glass sherds ( 5 with embossed letters)

5 wire nails; 1 cut nail

4 clear bottle glass sherds

1 brown bottle glass sherd

1 clear bottle glass sherd

1 plain porcelain body sherd

4 clear bottle glass sherds; 1 ceramic 4 -holed button; 4 wire nails; 3 unidentifiable nail shanks

2 burned clay/daub; 1 unidentifiable cast iron piece; 1 aqua bottle glass sherd; 1 plain whiteware body sherd

2 clear bottle glass sherds

2 cut nails; 5 wire nails; 1 iron key/opener; 1 aqua bottle glass sherd; 1 brown bottle glass sherd; 1 plain whiteware body sherd

1 iron fence staple; 1 piece of thin wire; 1 cut nail; 1 unidentifiable nail shank; 7 wire nails; 3 charred nutshells; 7 clear bottle glass sherds

1 hard plastic/bakelite fragment; 2 clear bottle glass sherds; 1 brown bottle glass sherd; 4 plain porcelain body sherds; 1 iron ball and hook; 1 cut nail; 1 unidentifiable nail shank

2 plain whiteware rim sherds; 1 clear bottle glass sherd; 3 wire nails; 1 iron wire; 1 unidentifiable nail shank

3 clear bottle glass sherds 
ST 498, 0-20 cm

ST 503, 0-20 cm

ST 504, 0-20 cm

Unit 356, 0-10 cm

41LN357

41LN364

41LN365

$41 \mathrm{LN} 372$
ST 510, 20-40 cm

ST 514, 40-60 cm

ST 514, 60-80 cm

Unit 357, 40-50 cm

Surface, adjacent to ST 736

ST 739, 0-20 cm

ST 740, 20-40 cm

ST $742,80-100 \mathrm{~cm}$

Unit 358, 0-10 cm

Unit 358, 60-70 cm

ST 767, 40-47 cm

Unit 363, 30-40 cm

ST 785, 80-100

Unit $364,90-100 \mathrm{~cm}$

ST 734, 0-20 cm

ST 738, 0-20 cm

Unit $365,0-10 \mathrm{~cm}$

ST $279,0-20 \mathrm{~cm}$

ST $282,0-20 \mathrm{~cm}$

ST $282,20-40 \mathrm{~cm}$

ST $282,40-60 \mathrm{~cm}$

ST $283,20-40 \mathrm{~cm}$

Unit 372, 0-10 cm

Unit $372,10-20 \mathrm{~cm}$

Unit 372, 20-30 cm

Unit 372, 30-40 cm
1 animal bone; 1 plain whiteware rim sherd; 1 embossed whiteware rim sherd

1 iron plow part

1 unidentifiable nail shank

2 plain whiteware body sherds; 1 plain whiteware base sherd; 3 aqua bottle glass sherds; 1 brown bottle glass sherd; 2 wire nails; 1 unidentifiable nail shank

2 non-cortical gray chert lithic debris

1 cortical petrified wood chunk; 1 non-cortical light gray chert lithic debris

1 wire nail

I non-cortical gray novaculite lithic debris

1 salt-glazed/lead-glazed stoneware rim sherd

1 plain porcelain body sherd

1 clear bottle glass sherd

1 non-cortical brown chert lithic debris

1 plain porcelain body sherd

1 cortical petrified wood lithic debris

l non-cortical grayish-brown chert lithic debris

2 non-cortical quartzite lithic debris

1 non-cortical quartzite lithic debris

I non-cortical yellow chert lithic debris

3 wire nails

2 tin can fragments

3 wire nails; 1 unidentifiable nail shank

1 burned clay; 1 aqua bottle glass sherd; 1 plain whiteware rim sherd; 1 plain whiteware body sherd; 1 cupreous collar/cuff stud

1 cut nail; 1 unidentifiable nail shank; 1 aqua bottle glass sherd; 2 brown bottle glass sherds; 4 wood charcoal pieces

2 animal bones; 1 wood charcoal piece; 2 aqua bottle glass sherds; 1 cut nail; 1 unidentifiable nail shank

1 cut nail; 1 thin cupreous band fragment; 1 piece of wood charcoal

1 clear bottle glass sherd; 1 cupreous possible suspender attachment

1 brown chert flake tool; 2 animal bones; 2 aqua bottle glass sherds

8 eggshell fragments; 3 pieces of wood charcoal; 1 animal bone; 3 hand-made brick fragments; 14 burned clay/daub

3 cut nails; 1 iron screw; 3 burned clay/daub; 1 hand-made brick fragment; 2 pieces of wood charcoal; 5 animal bones; 1 plain whiteware rim sherd; 1 plain whiteware body sherd

1 eggshell fragment; 4 pieces of wood charcoal; 3 animal bones; 1 hand-made brick fragment; 4 burned clay/daub; 1 aqua bottle glass sherd; 1 cut nail 
Unit $372,40-50 \mathrm{~cm}$

Unit $372,50-60 \mathrm{~cm}$
2 burned clay/daub; 1 unidentifiable nail shank; 2 animal bones/ teeth

2 eggshell fragments 


\title{
Appendix 4
}

\section{Detailed Analysis of Prehistoric Ceramic Sherds}

\author{
Timothy K. Perttula
}

\begin{tabular}{|c|c|c|c|c|c|c|}
\hline $\begin{array}{l}\text { PROVENIENCE } \\
\text { (CM BS) }\end{array}$ & $\begin{array}{l}\text { SHERD } \\
\text { TYPE }\end{array}$ & TEMPER & FC & ST & $\mathrm{TH}(\mathrm{MM})$ & DeCoration \\
\hline \multicolumn{7}{|l|}{$41 \mathrm{LN} 308$} \\
\hline \multirow[t]{2}{*}{ ST $363,40-60$} & body & $\mathrm{b} / \mathrm{SP}$ & B & - & 7.2 & plain \\
\hline & body & $\mathrm{b} / \mathrm{SP}$ & B & - & 7.0 & parallel brushed \\
\hline ST $365,20-40$ & body & $\mathrm{g} / \mathrm{SP}$ & B & I SM & $6.7-1.4$ & $\begin{array}{l}\text { opposed and cross-hatched engraved } \\
\text { lines, CB or CPB }\end{array}$ \\
\hline ST 381, 0-20 & body & $\mathrm{b}$ & G & - & 6.2 & plain \\
\hline ST $381,40-60$ & body & $\mathrm{b}$ & G & - & 6.3 & plain \\
\hline ST $409,0-20$ & body & $\mathrm{g} / \mathrm{SP}$ & $\mathrm{F}$ & - & 9.5 & closely-spaced parallel incised lines \\
\hline \multirow[t]{2}{*}{ Unit 308, 40-50 } & body & SP & B & E SM & 4.2 & plain \\
\hline & body & SP & A & I SM & 6.0 & plain \\
\hline Unit 308, 50-60 & rim & $g$ & B & - & 5.1 & opposed incised lines; RO \\
\hline \multicolumn{7}{|l|}{ 41LN320 } \\
\hline ST $359,60-80$ & body & SP & $E$ & - & 5.1 & plain \\
\hline \multicolumn{7}{|l|}{ 4lLN322 } \\
\hline ST 415, 0-20 & body & SP & B & I SM & 6.3 & plain \\
\hline \multicolumn{7}{|l|}{$41 \mathrm{LN} 323$} \\
\hline Unit 323, 30-40 & body & SP & $\mathrm{E}$ & - & 6.6 & plain \\
\hline \multicolumn{7}{|l|}{ 4lLN325 } \\
\hline \multirow[t]{2}{*}{ ST $608,60-80$} & body & SP & G & I SM & 6.3 & plain \\
\hline & body & SP & G & I SM & 5.7 & plain \\
\hline ST $610,20-40$ & rim & $\mathrm{b}-\mathrm{g} / \mathrm{SP}$ & B & I B & 8.1 & plain, D-RO \\
\hline ST $610,40-60$ & rim & g & B & I B & 7.2 & horizontal incised lines, D-RO \\
\hline ST $611,60-80$ & body & g & $\mathrm{E}$ & I SM & 7.2 & parallel incised-opposed brushed \\
\hline ST $612,60-80$ & body & SP & B & I/E SM & 5.4 & plain \\
\hline ST $618,40-60$ & body & $\mathrm{g} / \mathrm{SP}$ & $\mathrm{E}$ & - & 7.6 & plain \\
\hline ST $621,40-60$ & base & $\mathrm{b} / \mathrm{SP}$ & $\mathrm{F}$ & - & 10.5 & plain \\
\hline ST $621,80-100$ & base & - & $\mathrm{F}$ & - & 11.7 & plain \\
\hline ST $624,80-100$ & base & $\mathrm{g}-\mathrm{h} / \mathrm{SP}$ & $\mathrm{F}$ & E SM & 11.3 & plain \\
\hline ST $626,0-20$ & rim & SP & $\mathrm{H}$ & I SM & 8.4 & plain, but possibly lip notched; D-FL \\
\hline
\end{tabular}

Temper: $\mathrm{b}=$ bone; $\mathrm{g}=$ grog; $\mathrm{h}=$ hematite; $\mathrm{SP}=$ sandy paste; $\mathrm{FC}=$ firing condition (following Teltser [1993] and Perttula [2005]); $\mathrm{A}=$ oxidized; $\mathrm{B}=$ fired in a reducing environment; $\mathrm{C}-\mathrm{E}=$ incompletely oxidized during firing; $\mathrm{F}-\mathrm{H}$, fired in a reducing environment, and cooled in the open air; $\mathrm{I}-\mathrm{K}=$ irregular firing, sooting, or smudging; ST = surface treatment; $\mathrm{E}=$ exterior; I = interior; $\mathrm{SM}=$ smoothed; $\mathrm{B}=$ burnished; Rim and Lip Form: $\mathrm{D}=$ direct rim; Ro = rounded; Ro-ext $\mathrm{f}=$ rounded and exterior folded; FL = flat; Vessel Form: $\mathrm{CB}=$ carinated bowl $\mathrm{CPB}=$ compound bowl. 


\begin{tabular}{cllllll}
\hline $\begin{array}{c}\text { ProveniEnCE } \\
\text { (CM BS) }\end{array}$ & $\begin{array}{c}\text { ShERD } \\
\text { TYPE }\end{array}$ & TEMPER & FC & ST & TH (MM) & DeCORATION \\
\hline & body & g/SP & G & I/E B & 7.0 & plain \\
body & g/SP & B & I/E B & 6.9 & plain \\
ST 627, 0-20 & body & g-h/SP & D & - & 7.2 & plain \\
ST 628, 0-20 & rim & b/SP & B & I/E SM & 7.6 & plain, D-RO, ext f \\
ST 638, 20-40 & body & g & B & - & 7.5 & parallel incised lines \\
ST 638, 40-60 & body & g/SP & F & - & 8.2 & plain \\
Unit 325, 0-10 & body & b & G & - & 7.0 & plain \\
Unit 325, 20-30 & body & g & B & - & 5.5 & opposed incised lines \\
41LN341 & & & & & & \\
ST 79, 0-20 & body & SP & G & I SM & 7.4 & plain \\
ST 79, 60-75 & body & SP & G & E SM & 6.4 & plain \\
ST 90, 60-80 & body & SP & I & E SM & 8.9 & plain \\
ST 93, 0-20 & body & SP & G & E SM & 8.6 & plain \\
ST 95, 11 & body & g & D & I SM & 7.4 & parallel brushed \\
Unit 341, 20-30 & rim & SP & E & I/E SM & 5.7 & plain; D-RO \\
41LN343 & & & & & & \\
ST 877, 20-40 & body & g/SP & G & I/E SM & 6.6 & plain \\
\hline
\end{tabular}

Temper: $\mathrm{b}=$ bone; $\mathrm{g}=$ grog; $\mathrm{h}$ = hematite; $\mathrm{SP}=$ sandy paste; $\mathrm{FC}=$ firing condition (following Teltser [1993] and Perttula [2005]); $A$ = oxidized; $\mathrm{B}=$ fired in a reducing environment; $\mathrm{C}-\mathrm{E}$ = incompletely oxidized during firing; $\mathrm{F}-\mathrm{H}$, fired in a reducing environment, and cooled in the open air; $\mathrm{I}-\mathrm{K}=$ irregular firing, sooting, or smudging; ST = surface treatment; E = exterior; I = interior; SM = smoothed; B = burnished; Rim and Lip Form: $\mathrm{D}=$ direct rim; Ro = rounded; Ro-ext $\mathrm{f}=$ rounded and exterior folded; FL = flat; Vessel Form: $\mathrm{CB}=$ carinated bowl $\mathrm{CPB}=$ compound bowl.

\section{References Cited}

Perttula, T. K. (editor)

2005 Archeological Investigations at the Pilgrim's Pride Site (41CP304), a Titus Phase Community in the Big Cypress Creek Basin, Camp County, Texas. 2 Vols. Report of Investigations No. 30. Archeological \& Environmental Consultants, LLC, Austin.

Teltser, P. A.

1993 An Analytic Strategy for Studying Assemblage-Scale Ceramic Variation: A Case Study from Southeast Missouri. American Antiquity 58(3):530-543. 


\section{Appendix 5}

\section{Faunal Data}

Cinda L. Timperley

\begin{tabular}{|c|c|c|c|c|c|c|}
\hline SITE & Lот & Provenience & $\begin{array}{l}\text { DEPTH } \\
\text { (CM BS) }\end{array}$ & (N) & $\begin{array}{l}\text { WEIGHT } \\
(\mathrm{G})\end{array}$ & ITEMS \\
\hline $41 \mathrm{LN} 308$ & 91 & ST363 & $20-40$ & 2 & 0.7 & Mammalia burned bone fragments; one calcined \\
\hline 4lLN308 & 92 & ST363 & $40-60$ & 2 & 1.0 & Mammalia bone fragments \\
\hline $41 \mathrm{LN} 308$ & 92 & ST363 & $40-60$ & 1 & 0.5 & Mammalia burned diaphysis fragment \\
\hline $41 \mathrm{LN} 308$ & 93 & ST363 & $60-80$ & 4 & 0.5 & $\begin{array}{l}\text { Mammalia bone fragments; mend to one } \\
\text { element, fresh breaks }\end{array}$ \\
\hline 4lLN308 & 130 & ST403 & $20-40$ & 1 & 0.8 & Mammalia, medium, podial fragment, calcined \\
\hline $41 \mathrm{LN} 308$ & 133 & ST403 & $80-100$ & 1 & 0.1 & Mammalia calcined bone fragment \\
\hline $41 \mathrm{LN} 308$ & 136 & ST404 & $40-60$ & 5 & 0.7 & Mammalia, medium, bone fragments \\
\hline 4lLN308 & 151 & Unit 308 & 20-30 & 2 & 0.1 & $\begin{array}{l}\text { Vertebrata: Bird or Small Mammal, burned bone } \\
\text { fragment }\end{array}$ \\
\hline $41 \mathrm{LN} 308$ & 151 & Unit 308 & $20-30$ & 1 & 0.6 & Mammalia, medium or large, bone fragment \\
\hline $41 \mathrm{LN} 308$ & 152 & Unit 308 & $30-40$ & 1 & 1.1 & Mammalia, medium, burned bone fragment \\
\hline 4lLN309 & 160 & ST438 & $0-20$ & 1 & 1.5 & $\begin{array}{l}\text { Mammalia, medium, burned limb diaphysis } \\
\text { fragment }\end{array}$ \\
\hline 4lLN309 & 161 & ST438 & $20-26$ & 1 & 0.3 & $\begin{array}{l}\text { Mammalia, medium, burned limb diaphysis } \\
\text { fragment }\end{array}$ \\
\hline 4lLN309 & 166 & ST444 & $0-20$ & 2 & $<0.1$ & Mammalia, small, rib fragment, mend \\
\hline 41LN309 & 170 & Unit 309 & 20-30 & 1 & 0.6 & $\begin{array}{l}\text { Mammalia:Tayassuidae? Bunodont cheek tooth } \\
\text { fragment, in wear }\end{array}$ \\
\hline $41 \mathrm{LN} 318$ & 243 & Unit 318 & $40-50$ & 1 & 0.5 & Mammalia, medium, rib fragment, subadult \\
\hline $41 \mathrm{LN} 325$ & 349 & ST608 & $20-40$ & 1 & $<0.1$ & Testudines, plastron fragment, calcined \\
\hline $41 \mathrm{LN} 325$ & 349 & ST608 & $20-40$ & 1 & 1.2 & $\begin{array}{l}\text { Artiodactyla, medium, burned limb diaphysis } \\
\text { fragment }\end{array}$ \\
\hline $41 \mathrm{LN} 325$ & 350 & ST608 & $40-60$ & 1 & 0.4 & $\begin{array}{l}\text { Mammalia, medium, subadult limb diaphysis } \\
\text { fragment, calcined }\end{array}$ \\
\hline $41 \mathrm{LN} 325$ & 352 & ST608 & $80-100$ & 1 & 0.8 & Mammalia, medium, limb diaphysis fragment \\
\hline 41LN325 & 394 & ST627 & $0-20$ & 1 & 0.5 & Mammalia, pelvis(?) fragment, calcined \\
\hline $41 \mathrm{LN} 325$ & 403 & ST635 & $0-20$ & 1 & 0.1 & Testudines, shell fragment, calcined \\
\hline $41 \mathrm{LN} 325$ & 403 & ST635 & $0-20$ & 1 & 0.4 & $\begin{array}{l}\text { Mammalia, medium, limb diaphysis fragment, } \\
\text { burned }\end{array}$ \\
\hline 4lLN325 & 405 & ST635 & $40-60$ & 2 & 0.8 & Mammalia, bone fragments \\
\hline $41 \mathrm{LN} 325$ & 420 & Unit 325 & $0-10$ & 1 & 1.8 & Mammalia, medium, bone fragment, burned \\
\hline $41 \mathrm{LN} 325$ & 421 & Unit 325 & $10-20$ & 1 & 0.7 & Artiodactyla, medium, podial fragment, burned \\
\hline
\end{tabular}




\begin{tabular}{|c|c|c|c|c|c|c|}
\hline SITE & LоT & Provenience & $\begin{array}{l}\text { DEPTH } \\
\text { (CM BS) }\end{array}$ & $(\mathrm{N})$ & $\begin{array}{l}\text { WEIGHT } \\
\text { (G) }\end{array}$ & ITEMS \\
\hline $41 \mathrm{LN} 325$ & 421 & Unit 325 & $10-20$ & 2 & 3.1 & $\begin{array}{l}\text { Artiodactyla, medium, limb diaphysis fragment } \\
\text { A, mends bagged together; burned; heavily } \\
\text { rodent-gnawed }\end{array}$ \\
\hline 41LN325 & 421 & Unit 325 & $10-20$ & 3 & 3.9 & $\begin{array}{l}\text { Artiodactyla, medium, limb diaphysis fragment } \\
\text { B, mends bagged together; burned; heavily } \\
\text { rodent-gnawed }\end{array}$ \\
\hline $41 \mathrm{LN} 325$ & 421 & Unit 325 & $10-20$ & 7 & 11.6 & $\begin{array}{l}\text { Artiodactyla, medium, limb diaphysis fragment } \\
\text { C, mends bagged together; burned; heavily } \\
\text { rodent-gnawed }\end{array}$ \\
\hline $41 \mathrm{LN} 325$ & 421 & Unit 325 & 10-20 & 2 & 1.7 & $\begin{array}{l}\text { Artiodactyla, medium, limb diaphysis fragments, } \\
\text { similar to A, B, and C, but no mends apparent; } \\
\text { burned; heavily rodent-gnawed }\end{array}$ \\
\hline 41LN325 & 424 & Unit 325 & $40-50$ & 1 & 0.4 & Odocoileus mandibular cheek tooth fragment \\
\hline 41LN325 & 424 & Unit 325 & $40-50$ & 1 & 0.3 & $\begin{array}{l}\text { Odocoileus 2nd phalanx fragment, proximal } \\
\text { articular facet }\end{array}$ \\
\hline 41LN325 & 424 & Unit 325 & $40-50$ & 2 & 1.3 & $\begin{array}{l}\text { Mammalia, medium, limb bone diaphysis } \\
\text { fragments }\end{array}$ \\
\hline $41 \mathrm{LN} 325$ & 424 & Unit 325 & $40-50$ & 1 & 0.5 & $\begin{array}{l}\text { Mammalia, cf Bovidae, hypsodont tooth dentine } \\
\text { fragment }\end{array}$ \\
\hline $41 \mathrm{LN} 325$ & 425 & Unit 325 & $50-60$ & 3 & 0.3 & $\begin{array}{l}\text { Odocoileus maxillary cheek tooth fragments, } \\
\text { mend }\end{array}$ \\
\hline $41 \mathrm{LN} 325$ & 426 & Unit 325 & $60-70$ & 1 & 0.1 & Mammalia bone fragment \\
\hline $41 \mathrm{LN} 325$ & 426 & Unit 325 & $60-70$ & 1 & 0.1 & Mammalia bone fragment, calcined, cut \\
\hline 41LN325 & 426 & Unit 325 & $60-70$ & 1 & 0.2 & $\begin{array}{l}\text { Mammalia, medium, juvenile, bone fragment, } \\
\text { burned }\end{array}$ \\
\hline 41LN343 & 502 & ST889 & $60-80$ & 2 & 0.3 & Mammalia, calcined bone fragments \\
\hline $41 \mathrm{LN} 343$ & 504 & Unit 343 & $20-30$ & 1 & 0.3 & Mammalia, burned bone fragment \\
\hline 4lLN345 & 530 & ST841 & $20-40$ & 7 & 4.7 & Mammalia, medium, limb diaphysis fragments \\
\hline $41 \mathrm{LN} 356$ & 596 & ST498 & $0-20$ & 1 & 0.2 & Mammalia, small or medium, rib fragment \\
\hline $41 \mathrm{LN} 372$ & 619 & ST282 & $20-40$ & 1 & 2.0 & $\begin{array}{l}\text { Mammalia, medium, limb diaphysis fragment, } \\
\text { burned }\end{array}$ \\
\hline 4lLN372 & 619 & ST282 & $20-40$ & 1 & 1.1 & Tayassu? Incisor fragment \\
\hline 41LN372 & 622 & Unit 372 & $0-10$ & 1 & 0.2 & Mammalia bone fragment, calcined \\
\hline 4lLN372 & 622 & Unit 372 & $0-10$ & 1 & 0.7 & Artiodactyla, medium, limb diaphysis fragment \\
\hline 4lLN372 & 623 & Unit 372 & 10-20 & 1 & 0.5 & Mammalia, bone fragment \\
\hline 4lLN372 & 624 & Unit 372 & $20-30$ & 3 & 12.4 & Mammalia, large, rib fragments, mend \\
\hline 41LN372 & 624 & Unit 372 & $20-30$ & 2 & 1.1 & $\begin{array}{l}\text { Mammalia, medium or large, bone fragments, } \\
\text { calcined }\end{array}$ \\
\hline $41 \mathrm{LN} 372$ & 625 & Unit 372 & $30-40$ & 2 & 0.6 & Mammalia, bone fragments, burned \\
\hline
\end{tabular}




\begin{tabular}{cclcccl}
\hline Site & Lot & ProveniENCE & $\begin{array}{c}\text { DePTH } \\
\text { (CM BS) }\end{array}$ & (N) & $\begin{array}{c}\text { WeIGHT } \\
(\mathrm{G})\end{array}$ & \multicolumn{1}{c}{ ITEMS } \\
\hline $41 \mathrm{LN} 372$ & 625 & Unit 372 & $30-40$ & 1 & 0.7 & $\begin{array}{l}\text { Mammalia, medium or large, burned rib } \\
\text { fragment }\end{array}$ \\
$41 \mathrm{LN} 372$ & 626 & Unit 372 & $40-50$ & 1 & 1.0 & $\begin{array}{l}\text { Mammalia, medium or large, bone fragment, } \\
\text { burned }\end{array}$ \\
$41 \mathrm{LN} 372$ & 626 & Unit 372 & $40-50$ & 1 & 2.4 & Tayassu maxillary left incisor \\
\hline
\end{tabular}




\title{
Appendix 6
}

\section{Floral Remains from 1/4-inch Screen Samples at Three Sites: 41LN308, 41LN325, and 41LN343}

\author{
Leslie L. Bush
}

Fifty-one samples of carbonized plant material collected by $1 / 4$-inch screen from sites in Fort Boggy State Park were submitted for identification and analysis. These samples came from sites that were each investigated with shovel tests and a $50 \times 50 \mathrm{~cm}$ unit as part of a re-assessment of sites at the park.

Ten samples, including three radiocarbon samples, were from $41 \mathrm{LN} 308$, which lies on an alluvial terrace overlooking Boggy Creek. Archaic, Woodland, and post-A.D. 1200 Caddo components are represented in the artifact assemblage. Soils at the site are loamy fine sands. Common vegetation consists of grasses, bull nettle, and a few scattered hardwoods (see main body of the report for detailed descriptions of the three sites).

Thirty-three samples, including three radiocarbon samples, were submitted from the Black Finger Tip site (4lLN325). The site is situated on a natural rise on an alluvial terrace or floodplain surface near Boggy Creek, and is covered with hardwoods and a thick understory of yaupon and mustang grape. Soils are fine sandy loams. Woodland, post-A.D. 1200 Caddo, and nineteenth-century historical artifacts were recovered in the archaeological investigations.

Fourteen samples were submitted from the Fern Slope site (4lLN343), where a post-A.D. 900-1200 component is represented in the artifact assemblage. The site lies on an upland slope above the floodplain of Boggy Creek and one of its tributaries. Soils are loamy fine sands, and current vegetation consists of mixed hardwoods, yaupon, American beautyberry, grapevines, and greenbrier.

\section{Post Oak Savannah vegetation}

Fort Boggy State Park lies in the Post Oak Savannah ecological region, which many ecologists conceptualize as a transition zone between the Eastern Woodlands and the grasslands of the mid-continent (Diggs et al. 2006). Others point out that the Post Oak Savannah is floristically very similar to the Pineywoods, a perspective that may help make sense of the geographic extension of Caddo groups outside the Pineywoods region in Texas (MacRoberts and MacRoberts 2004; MacRoberts et al. 2002).

The Post Oak Savannah is broadly characterized by sandy soils, grasslands, and widely spaced trees. The most common trees are post oak (Quercus stellata), blackjack oak (Q. marilandica), and black hickory (Carya texana). Common grasses include the tall grass prairie trio of little bluestem (Schizachyrium scoparium), Indian grass (Sorghastrum nutans), and switchgrass (Panicum virgatum) (Diggs et al. 2006:116). There is much local variation within the Post Oak Savannah, however. At the Fort Boggy sites, Boggy Creek and nearby slopes would have conditioned variation in plant species during Late Prehistoric times. Water oak (Quercus nigra) and post oak would have dominated floodplain forests along with elms (Ulmus spp.), and green ash (Fraxinus pennsylvanica). Grape vines (Vitis spp.), poison ivy (Toxicodendron radicans), sedges (Cyperaceae), and wet land grasses such as wildrye (Elymus spp.) and wood oats (Chasmanthium 
spp.) would also have been common (Diggs et al. 2006:122-123).

Modern equivalents exist for most prehistoric plant communities in East Texas despite changes in the abundance and structure of the communities (Diggs et al. 2006:87). The most notable changes on the Post Oak Savannah since pre-settlement times include an increase in woody vegetation (e.g., the thick understory noted on archaeological sites in the Park) and the loss of "bottom prairie" communities along major rivers such as the Brazos and Trinity (Diggs et al. 2006:115-116). Pollen studies indicate that use of the modern vegetation zones described above is appropriate for understanding the plants and attendant animal resources available to people during the first and second millennia A.D. Weakly Bog, situated on Post Oak Savannah vegetation in Leon County, provides some of the best data for vegetation reconstruction in the eastern half of Texas during the last 3,000 years (Bousman 1998). Pollen profiles from this bog indicate oak and later oak/hickory woodlands, suggesting that modern plant communities generally provide good analogs for historical Texas plant communities during the last 3,000 years. A recent study in southwest Upshur County provides supporting data for the Late Prehistoric period (Albert 2007). Some fluctuations in rainfall and temperature have taken place (Bousman 1998:204), but even decades-long fluctuations in rainfall patterns seem to be part of the natural background of Late Holocene climate patterns (Stahle and Cleaveland 1992). In addition, more frequent fires in the past would have made the woody vegetation less prominent than during the last century or so (Diggs et al. 2006; MacRoberts et al. 2002).

\section{Laboratory Methods}

Full radiocarbon protocols were followed for the six samples designated for radiocarbon dating. Three samples each came from $41 \mathrm{LN} 308$ and the Black Finger Tip site (4lLN325); they are indicated in Tables A6.1 and A6.2. Radiocarbon samples were sorted on freshly cleaned glassware and handled only with latex gloves and metal forceps. They were not screened, and contact with paper was avoided. Only one radiocarbon sample was open at a time in the laboratory. Writing instruments used for data recording of radiocarbon samples were plastic mechanical pencils.

Table A6.1. Radiocarbon dates from 41LN308.

\begin{tabular}{lccccc}
\hline $\begin{array}{c}\text { LAB No. } \\
\text { (UCLAMS) }\end{array}$ & $\begin{array}{c}\text { PROVENIENCE } \\
\text { (CM BS) }\end{array}$ & $\begin{array}{c}\text { ConVENTIONAL } \\
\text { Age (B.P.) }\end{array}$ & $\begin{array}{c}\text { 1 SIGMA CAL AGE } \\
\text { RANGE (B.P.) }\end{array}$ & $\begin{array}{c}\text { 2 SIGMA CAL AGE } \\
\text { RANGE (B.P.) }\end{array}$ & $\begin{array}{c}\text { S SIGMA RELATIVE } \\
\text { AREA UNDER } \\
\text { PROBABILITY } \\
\text { DISTRIBUTION }\end{array}$ \\
\hline 95417 & ST 363, 40-60 & $1100 \pm 15$ & $970-1051$ & $963-1015$ & $57.2 \%$ \\
95418 & & & & $1022-1056$ & $38.2 \%$ \\
95419 & ST 403, 60-80 & $1275 \pm 15$ & $1182-1263$ & $1178-1270$ & $95.4 \%$ \\
\hline
\end{tabular}


Table A6.2. Radiocarbon dates from the Black Finger Tip site (41 LN325).

\begin{tabular}{|c|c|c|c|c|c|}
\hline $\begin{array}{c}\text { LAB No. } \\
\text { (UCIAMS) }\end{array}$ & $\begin{array}{l}\text { PROVENIENCE } \\
\text { (CM BS) }\end{array}$ & $\begin{array}{c}\text { Conventional } \\
\text { Age (B.P.) }\end{array}$ & $\begin{array}{l}1 \text { SIGMA CAL AGE } \\
\text { RANGE (B.P.) }\end{array}$ & $\begin{array}{c}2 \text { SIGMA CAL AGE } \\
\text { RANGE (B.P.) }\end{array}$ & $\begin{array}{c}2 \text { SIGMA RELATIVE } \\
\text { AREA UNDER } \\
\text { PROBABILITY } \\
\text { DISTRIBUTION }\end{array}$ \\
\hline \multirow[t]{2}{*}{95420} & ST $609,20-40$ & $1300 \pm 15$ & $1186-1281$ & $1230-1286$ & $63.6 \%$ \\
\hline & & & & $1186-1202$ & $31.8 \%$ \\
\hline 95421 & Unit $325,80-90$ & $2720 \pm 15$ & $2784-2845$ & $2774-2854$ & $95.4 \%$ \\
\hline
\end{tabular}

Identification procedures were the same for all samples. Each charcoal fragment was examined under a stereoscopic microscope at 7-28 X magnification for initial identification. Genus or species identification was attempted for all wood charcoal fragments. Wood charcoal fragments were snapped to reveal a transverse section and examined under a stereoscopic microscope at 28-180 X magnification. When necessary, tangential or radial sections were examined for ray seriation, presence of spiral thickenings, types and sizes of inter-vessel pitting, and other minute characteristics that can only be seen at the higher magnifications of this range.

Botanical materials were identified to the lowest possible taxonomic level by comparison to materials in the Macrobotanical Analysis comparative collection and through the use of standard reference works (Core et al. 1979; Davis 1993; Hoadley 1990; InsideWood 2004-onwards; Martin and Barkley 2000; Panshin and de Zeeuw 1980). Plant nomenclature follows that of the PLANTS Database (USDA, NRCS 2011). When identification was complete, weights were measured on an Ohaus Scout II $200 \times 0.01 \mathrm{~g}$ electronic balance, counts were recorded, and all material was bagged and labeled for curation.

\section{Results}

Taxa identified in the samples are shown in Table A6.1-A6.3. All materials are fully carbonized and considered ancient unless otherwise indicated.

Table A6.3. Carbonized Plant Remains from Fort Boggy State Park

\begin{tabular}{ccclllcc}
\hline LOt NUMBER & UnIT & DEPTH (CM) & PLANT PART & BotanicAl NAME & Common NAME & Count & WEIGHT (G) \\
\hline $92^{*}$ & 363 & $40-60$ & Nutshell & Carya sp. & Hickory & 2 & 0.13 \\
97 & 364 & $60-80$ & Nutshell & Carya sp. & Hickory & 2 & 0.12 \\
130 & 403 & $20-40$ & Nutshell & Carya sp. & Hickory & 1 & 0.18 \\
131 & 403 & $40-60$ & Nutshell & Carya sp. & Hickory & 1 & 0.03 \\
$132^{*}$ & 403 & $60-80$ & Nutshell & Carya sp. & Hickory & 3 & 0.21 \\
135 & 404 & $20-40$ & Nutshell & Carya sp. & Hickory & 1 & 0.10 \\
136 & 404 & $40-60$ & Nutshell & Carya sp. & Hickory & 5 & 0.14 \\
$151^{*}$ & 308 & $20-30$ & Nutshell & Carya sp. & Hickory & 4 & 0.38 \\
$151^{*}$ & 308 & $20-30$ & Wood** & Indeterminable & Indeterminable & 1 & 0.03 \\
152 & 308 & $30-40$ & Nutshell & Carya sp. & Hickory & 5 & 0.29 \\
155 & 308 & $70-80$ & Nutshell & Carya sp. & Hickory & 2 & 0.14 \\
\hline
\end{tabular}

*radiocarbon sample, **incompletely carbonized 
Hickory nutshell was by far the most common plant type recovered at all sites. From 41 LN308, hickory nutshell and an indeterminable wood charcoal were identified. The wood charcoal is not quite full carbonized and is not recommended for radiocarbon dating. Plant remains from the Black Finger Tip site (4lLN325) consisted of hickory nutshell, acorn nut meat, wood charcoal from an indeterminable hardwood, and hickory wood charcoal. The Fern Slope site (LN343), which had the largest number of samples, yielded two types of nutshell (hickory and black walnut), two types of wood charcoal (hickory and oak), and thin hickory nut hulls.

\section{Discussion}

All three plant taxa represented in the samples (hickory, oak, and black walnut) are common in the Boggy Creek area. Although black walnut never occurs in large groves, it thrives in deep soils along streams (Simpson 1999:178).

The species of hickory represented at the Fort Boggy sites is probably black hickory (Carya texana). This hickory produces both the thin hulls and thick shells found at the sites. Black hickory has pecan-type wood (i.e., banded parenchyma present in the earlywood), but wood identified to the genus Carya at the Fort Boggy sites could not be further specified. The wood was highly reflective and some anatomical features were obscured by cell fusion, suggesting carbonization at relatively high temperatures (Scott 2001).

Nut mast is the only food plant debris represented at the Fort Boggy sites. This is not surprising because nutshell is relatively large and tough, and it is likely to have been disposed of in a campfire, which would also contribute to its preservation on an archaeological site. The two types of nut resources represented at the Fort Boggy sites differ nutritionally. Hickory nutmeat is high in fat and contains more protein than most plant foods. Acorns are nutritionally more similar to grains such as corn in protein and carbohydrate content rather than to hickory nuts (Table A6.4).

Table A6.4. Proximate Analysis of Three Edible Tree Nuts and Corn Meal per $100 \mathrm{~g}$ Dry Weight (USDA, ARS 2010)

\begin{tabular}{lrrrr}
\hline & HiCKORY & WALNUT & ACORN & $\begin{array}{c}\text { YELLOW } \\
\text { CORNMEAL }\end{array}$ \\
\hline Fat (g) & 64 & 59 & 31 & 4 \\
Protein (g) & 13 & 24 & 8 & 8 \\
Carbohydrate (g) & 18 & 10 & 53 & 77 \\
Water (g) & 2 & 5 & 5 & 4 \\
Energy (kcal) & 657 & 618 & 509 & 362 \\
\hline
\end{tabular}




\section{References Cited}

Albert, Bruce M.

2007 Climate, Fire, and Land-use History in the Oak-Pine-Hickory Forests of Northeast Texas during the past 3500 Years. Castanea 72(2):82-91.

Bousman, C. Britt

1998 Paleoenvironmental Change in Central Texas: The Palynological Evidence. Plains Anthropologist 43(164):201-219.

Core, H. A., W. A. Cote, and A. C. Day

1979 Wood Structure and Identification. 2nd Edition Syracuse University Press, Syracuse, New York.

Davis, Linda W.

1993 Weed Seeds of the Great Plains: A Handbook for Identification. University Press of Kansas, Lawrence.

Diggs Jr., George M., Barney L. Lipscomb, Monique D. Reed and Robert J. O’Kennon

2006 Illustrated Flora of East Texas, Volume One: Introduction, Pteridophytes, Gymnosperms, and Monocotyledons. Sida, Botanical Miscellany, No. 26. Botanical Research Institute of Texas, Fort Worth.

Hoadley, R. Bruce

1990 Identifying Wood: Accurate Results with Simple Tools. The Taunton Press, Newtown, Connecticut.

InsideWood

2004-onwards. Published on the Internet. http://insidewood.lib.ncsu.edu/search. Accessed May 19, 2011.

MacRoberts, Barbara R., Michael H. MacRoberts, and James C. Cathey

2002 Floristics of Xeric Sandylands in the Post Oak Savanna Region of East Texas. Sida 20(1):373-386.

MacRoberts, Michael H. and Barbara R. MacRoberts

2004 The Post Oak Savanna Ecoregion: A Floristic Assessment of its Uniqueness. Sida 21(1):399-407.

Martin, Alexander C. and William D. Barkley

2000 Seed Identification Manual. The Blackburn Press, Caldwell, New Jersey.

Panshin, A. J. and Carol de Zeeuw

1980 Textbook of Wood Technology: Structure, Identification, Properties, and Uses of the Commercial

Woods of the United States and Canada. Fourth Edition. McGraw-Hill Book Company, New York.

Scott, Andrew C.

2001 Preservation by Fire. In Palaeobiology II, edited by Derek E. G. Briggs and Peter R. Crowther, pp. 277-280. Blackwell Science, London.

Simpson, Benny J.

1999 A Field Guide to Texas Trees. Lone Star Books. Laham, Massachusetts. 
Stahle, David W. and Malcolm K. Cleaveland

1992 Reconstruction and Analysis of Spring Rainfall over the Southeastern U.S. for the Past 1000 Years. Bulletin of the American Meteorological Society 73(12):1947-1961.

USDA, ARS (United States Department of Agriculture, Agricultural Research Service)

2010 USDA National Nutrient Database for Standard Reference. Release 23. http://www.ars.usda.gov/ ba/bhnrc/ndl. Accessed May 20, 2011.

USDA, NRCS (United States Department of Agriculture, Natural Resources Conservation Service)

2011 The PLANTS Database. http://plants.usda.gov. National Plant Data Center, Baton Rouge, Louisiana 70874-4490. Accessed May 19, 2011. 

Dispersal of this publication conforms with Texas State Documents Depository Law, and it is available at Texas State Publications Clearinghouse and/or Texas Depository Libraries.

$$
\text { (C) TPWD PWD RP P4503-0146C (11/11) }
$$

TPWD receives federal assistance from the U.S. Fish and Wildlife Service and other federal agencies and is subject to Title VI of the Civil Rights Act of 1964, Section 504 of the Rehabilitation Act of 1973, Title II of the Americans with Disabilities Act of 1990, the Age Discrimination Act of 1975, Title IX of the Education Amendments of 1972, and state anti-discrimination laws which prohibit discrimination the basis of race, color, national origin, age, sex or disability. If you believe that you have been discriminated against in any TPWD program, activity or facility, or need more information, please contact Civil Rights Coordinator for Public Access, U.S. Fish and Wildlife Service, 4401 N. Fairfax Drive, Mail Stop: MBSP-4020, Arlington, VA 22203.

Texas Parks and Wildlife Department

4200 Smith School Road

Austin, Texas 78744

www.tpwd.state.tx.us 



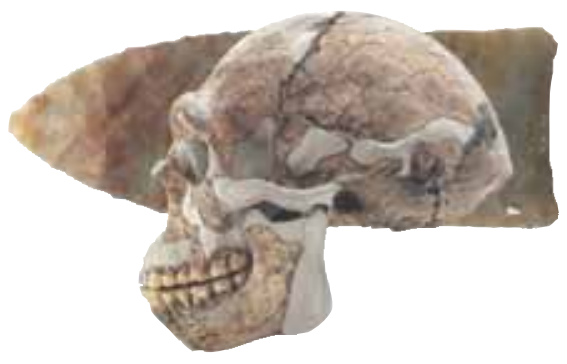

Center for Archaeological Studies

Texas State University-San Marcos

601 University Drive

San Marcos, TX 78666

www.txstate.edu/anthropology/cas/

\section{TEXAS $*$ STATE}

UNIVERSITY

SAN MARCOS

The rising STAR of Texas

A member of The Texas State University System 